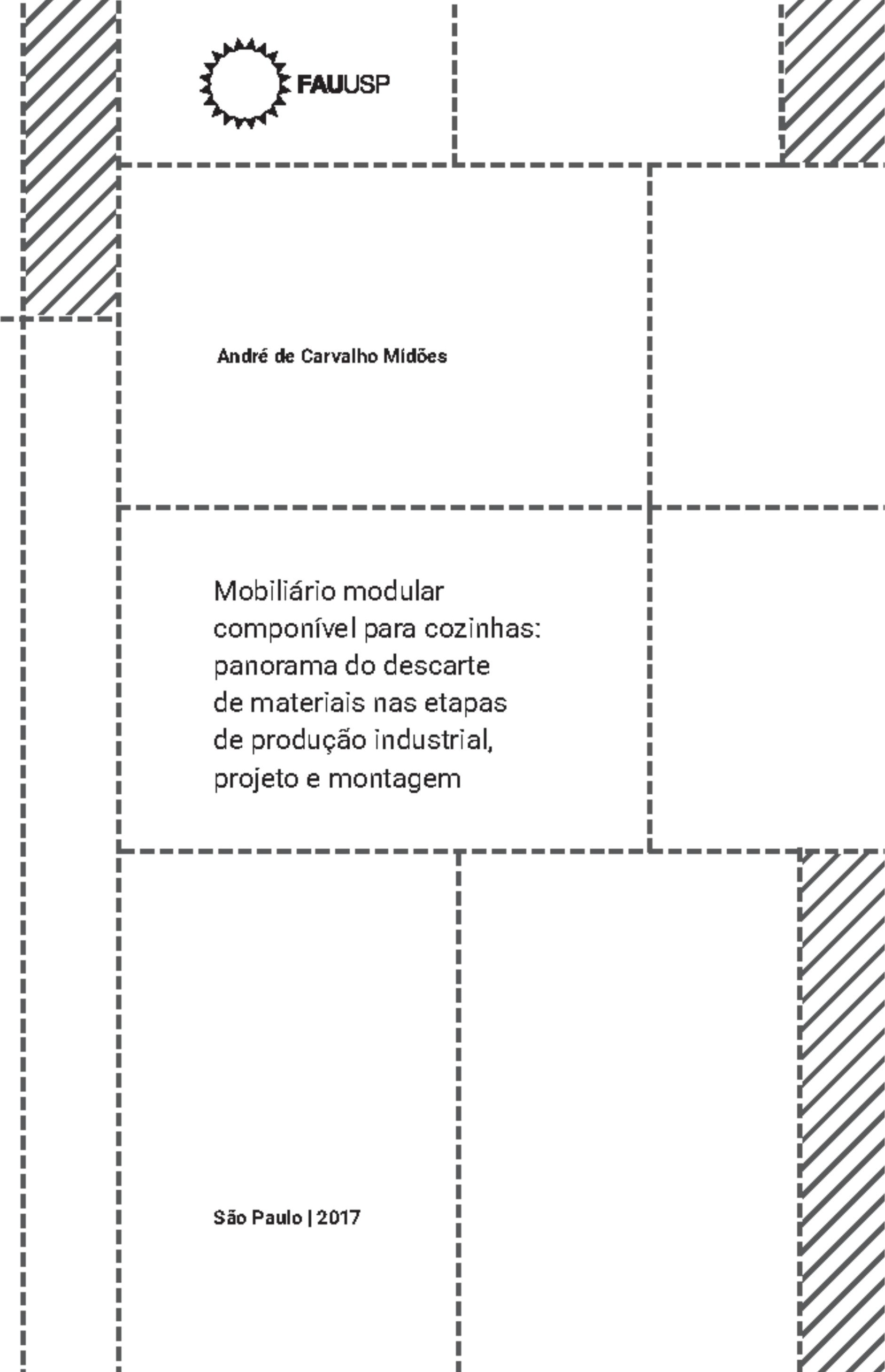




\section{ANDRÉ DE CARVALHO MIDÕES}

\section{Mobiliário modular componível para cozinhas: panorama do descarte de materiais nas etapas de produção industrial, projeto e montagem.}

Dissertação de Mestrado apresentada à Faculdade de Arquitetura e Urbanismo da Universidade de São Paulo para obtenção do título de Mestre em Ciências.

Área de concentração: Design e Arquitetura Orientadora: Profa. Dra. Cristiane Aun Bertoldi 
AUTORIZO A REPRODUÇÃO E DIVULGAÇÃO TOTAL OU PARCIAL DESTE TRABALHO, POR QUALQUER MEIO, CONVENCIONAL OU ELETRÔNICO, PARA FINS DE ESTUDO E PESQUISA, DESDE QUE CITADA A FONTE.

E-MAIL DO AUTOR: midoes.andre@gmail.com

Midões, André de Carvalho

M627m Mobiliário modular componível para cozinhas: panorama do descarte de materiais nas etapas de produção industrial, projeto e montagem / André de Carvalho Midões. -- São Paulo, 2017. 129 p. : il.

Dissertação (Mestrado - Área de Concentração: Design e Arquitetura) - FAUUSP.

Orientadora: Cristiane Aun Bertoldi

1.Desenho industrial 2.Design de produtos 3.Mobiliário doméstico 4.Cozinha 5.Descarte de materiais I.Título

CDU 7.05

EXEMPLAR REVISADO E ALTERADO EM RELAÇÃO À VERSÃO ORIGINAL, SOB RESPONSABILIDADE DO(A) AUTOR(A) E ANUÊNCIA DO ORIENTADOR(A).

A versão original, em formato digital, ficará arquivada na Biblioteca da Faculdade.

São Paulo, 18 de maio de 2017. 


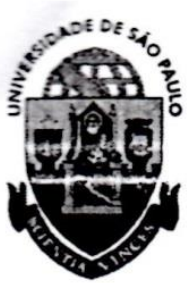

\section{Universidade de São Paulo}

\section{ATA DE DEFESA}

Aluno: 16134 - 8999594 - 2 / Página 1 de 1

Ata de defesa pública de Dissertação do(a) Senhor(a) André de Carvalho Midões no Programa: Arquitetura e Urbanismo, do(a) Faculdade de Arquitetura e Urbanismo da Universidade de São Paulo.

Aos 12 dias do mês de abril de 2017, no(a) sala no 24 realizou-se a Defesa da Dissertação do(a) Senhor(a) André de Carvalho Midões, apresentada para a obtenção do título de Mestre intitulada:

"Mobliário modular componível para cozinhas: panorama do descarte de materias nas etapas de produção industrial, projeto e montagem"

Após declarada aberta a sessão, o(a) Sr(a) Presidente passa a palavra ao candidato para exposição e a seguir aos examinadores para as devidas arguições que se desenvolvem nos termos regimentais. Em seguida, a Comissão Julgadora proclama o resultado:

$\begin{array}{llll}\text { Nome dos Participantes da Banca } & \text { Função } & \text { Sigla da CPG } & \text { Resultado } \\ \text { Cristiane Aun Bertoldi } & \text { Presidente } & \text { FAU - USP } \\ \text { Teresa Maria Riccetti } & \text { Titular } & \text { UPM - Externo } \\ \text { Antonio Franco } & \text { Titular } & \text { UNIP-Norte - Externo APROVADO }\end{array}$

Resultado Final: Aprorado

\section{Parecer da Comissão Julgadora *}

Eu, Dina Vasconcellos Leone , lavrei a presente ata, que assing juntamente com os(as) Senhores(as). São Paulo, aos 12 dias do mês de abril de 2017.

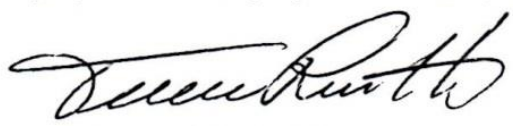

Teresa Maria Riccetti
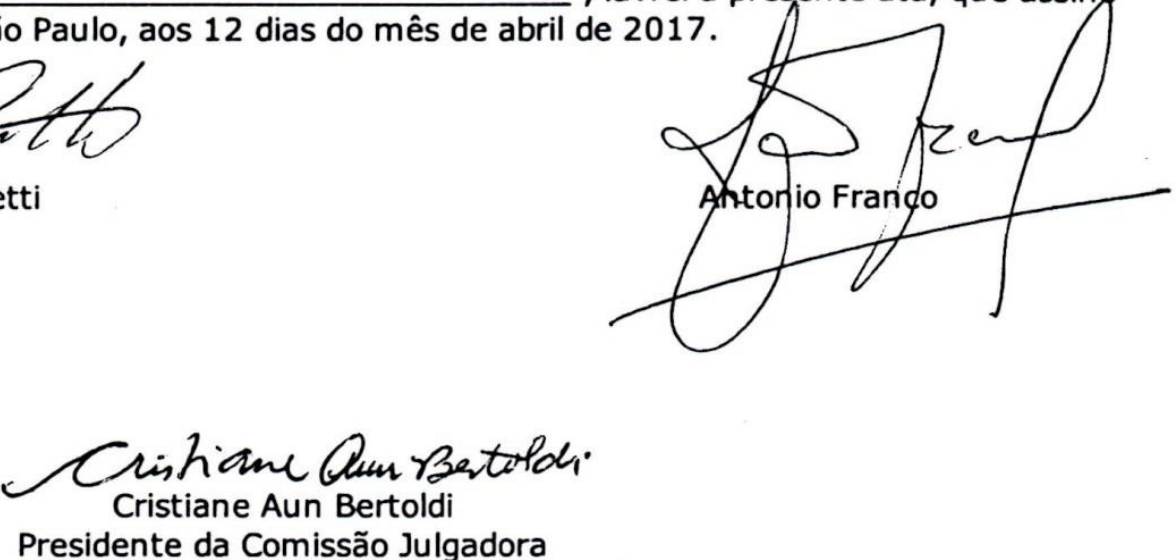

* Obs: Se o candidato for reprovado por algum dos membros, o preenchimento do parecer é obrigatório.

A defesa foi homologada pela Comissão de Pós-Graduação em e, portanto, o(a) aluno(a) faz jus ao título de Mestre em Ciências obtido no Programa Arquitetura e Urbanismo - Área de concençração: Design e Arquitetura. 
Dedico esta pesquisa à memória de meu pai. 


\section{Agradecimentos}

À minha orientadora, profa. Dra. Cristiane Aun Bertoldi, por acreditar neste trabalho e sempre me apoiar nos momentos de dificuldade.

Aos professores da Faculdade de Arquitetura e Urbanismo da Universidade de São Paulo, os quais tive o privilégio de ser aluno nas disciplinas da pós-graduação: Profa. Dra. Cibele Haddad Taralli, Profa. Dra. Daniela Hanns, Prof. Dr. Luis Claudio Portugal do Nascimento, Profa. Titular Maria Cecília Loschiavo dos Santos e Profa. Dra. Tatiana Sakurai.

Aos professores do curso de Design da Universidade de São Paulo: Profa. Dra. Denise Dantas e Prof. Dr. Marcelo Oliveira, por me aceitarem como monitor na graduação.

A todos os colegas da pós-graduação da Faculdade de Arquitetura e Urbanismo da Universidade de São Paulo pela amizade e companheirismo, em especial Lia Assumpção, que gentilmente fez o projeto gráfico da capa.

À amiga Lucilla Silveira Leite Pimentel, pela dedicada leitura e apontamentos necessários.

E um agradecimento mais que especial a todos os diretores industriais, empresários, engenheiros, técnicos de produção, designers, projetistas, montadores de móveis e profissionais do setor que acreditaram neste trabalho e dedicaram parte do seu tempo para contribuir com o seu conhecimento. Sem vocês este trabalho não seria possível. 
Não sou nada.

Nunca serei nada.

Não posso querer ser nada.

À parte isso, tenho em mim todos os sonhos do mundo.

Álvaro de Campos 


\section{Resumo}

Esta investigação tem como ponto de partida a preocupação contemporânea quanto ao desenvolvimento de produtos sustentáveis e, desta forma, considera-se como objeto do estudo o descarte de materiais pré-consumo no segmento de móveis modulados componíveis para cozinhas, popularmente denominados "móveis planejados", que tem como uma das principais características o desenvolvimento de projetos personalizados a partir de módulos padronizados. Com o objetivo de traçar um panorama qualitativo do tema e olhar a questão a partir de uma visão sistêmica do processo, a coleta de dados partiu de três principais enfoques: produção industrial, projeto e montagem dos móveis. Na fase de produção industrial, foram utilizadas entrevistas com profissionais e especialistas do setor, tais como empresários industriais, engenheiros de produção, designers do produto e feita observação não participante nas indústrias em que os móveis são produzidos. Na fase de projeto técnico, buscou-se junto aos projetistas compreender a relação entre o objeto da investigação e os métodos projetuais utilizados durante o processo de criação e na fase de montagem, final do processo, a coleta de dados foi realizada por meio de entrevistas e da observação não participante com os montadores durante a instalação dos móveis nas cozinhas. Como resultado, são apresentados os dados mais relevantes quanto ao descarte de materiais neste segmento do mobiliário residencial, identificando-se os tipos recorrentes de material descartado, sua eventual destinação e as principais circunstâncias no sistemaproduto geradoras destes insumos, apontando caminhos para novas investigações e abordagens, dentro e fora da área de design.

\section{Palavras chaves}

1. Desenho industrial. 2. Design de produtos. 3. Mobiliário doméstico. 4. Cozinha.

5. Descarte de materiais.

\section{ABSTRACT}

This research has as its starting point the contemporary concern about the development of sustainable products and, therefore, the object of the study is considered the disposal of preconsumption materials in the segment of modular furniture for kitchens, popularly called "planned furniture", which has as one of the main characteristics the development of customized projects from standardized modules. With the objective of tracing a qualitative panorama of the theme and looking at the question from a systemic view of the process, the data collection came from three main focuses: industrial production, design and furniture assembly. In the industrial production phase, interviews with professionals and industry experts such as industrial entrepreneurs, production engineers, product designers and nonparticipant observation were used in the industries in which the furniture is produced. In the technical design phase, the designers sought to understand the relationship between the object of the investigation and the design methods used during the creation process, and in the assembly phase, at the end of the process, the data collection was performed through interviews And the non-participant observation with the assemblers during the installation of the furniture in the kitchens. As a result, we present the most relevant data regarding the disposal of materials in this segment of residential furniture, identifying the recurrent types of discarded material, their eventual destination and the main circumstances in the productsystem generating these inputs, pointing out the ways for further investigations and approaches, inside and outside the design area.

\section{Keywords:}

1. Industrial design. 2. Product design. 3. Household furniture. 4. Kitchen.

5. Disposal of materials. 


\section{Lista de abreviaturas}

\begin{tabular}{|c|c|c|}
\hline Abrinq & - & Associação Brasileira dos Fabricantes de Brinquedos \\
\hline AP & - & (laminado de) Alta Pressão \\
\hline $\mathrm{BP}$ & - & (laminado de) Baixa Pressão \\
\hline $\mathrm{CNC}$ & - & Computer Numeric Control \\
\hline CNPJ & - & Cadastro Nacional de Pessoa Jurídica \\
\hline EPS & - & Poliestireno Expandido \\
\hline $\mathrm{FF}$ & - & Finishing Foil \\
\hline FSC & - & Forest Stewardship Council \\
\hline GRAACC & - & Grupo de Apoio às Crianças com Câncer \\
\hline IBA & - & Indústria Brasileira de Árvores \\
\hline ICMS & - & Imposto sobre Circulação de Mercadorias \\
\hline IEMI & - & Instituto de Pesquisa e Inteligência de Mercado \\
\hline MDF & - & Medium Density Fiberboard \\
\hline MDP & - & Medium Density Particles \\
\hline PCP & - & Planejamento e Controle de Produção \\
\hline PEBD & - & Polietileno de Baixa Densidade \\
\hline PVC & - & Policloreto de Vinila \\
\hline PNRS & - & Política Nacional de Resíduos Sólidos \\
\hline ONG & - & Organização não Governamental \\
\hline SNIF & - & Sistema Nacional de Informações Florestais \\
\hline UFMG & - & Universidade Federal de Minas Gerais \\
\hline
\end{tabular}




\section{Sumário}

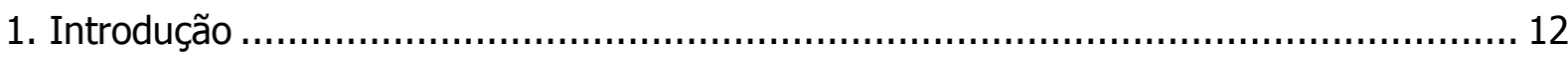

1.1 Contextualização e justificativa da pesquisa ...................................................... 13

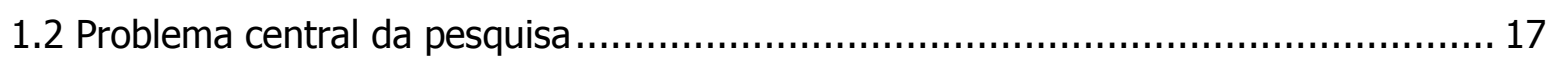

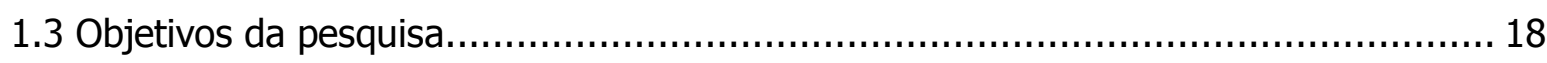

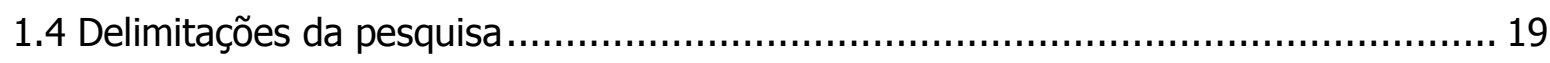

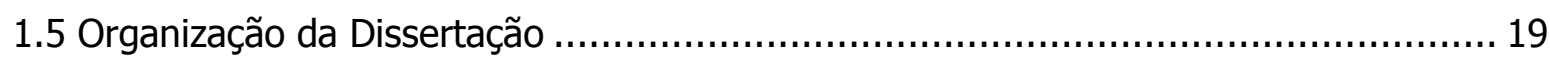

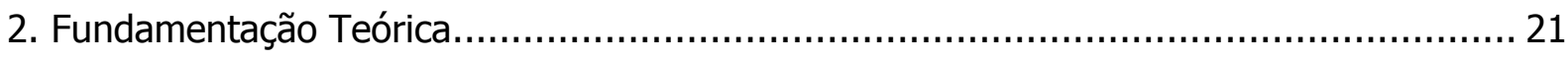

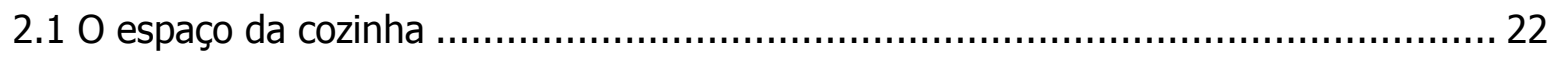

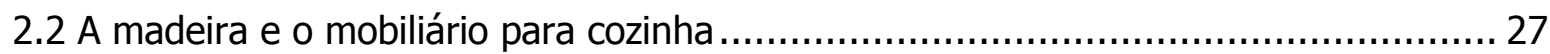

2.3 Modulados componíveis para cozinha ........................................................... 35

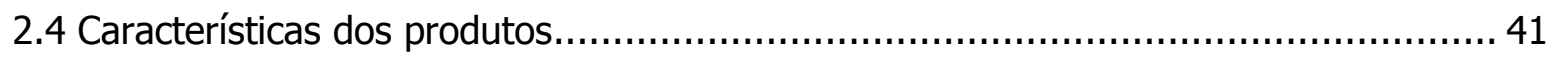

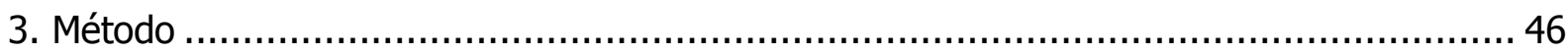

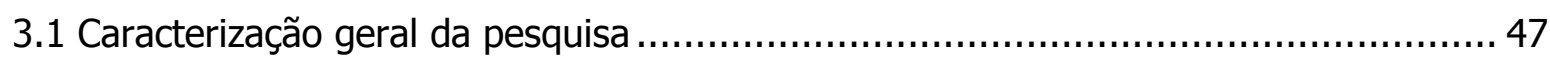

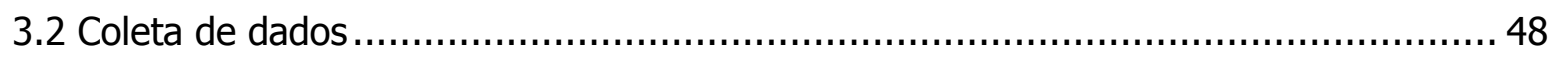

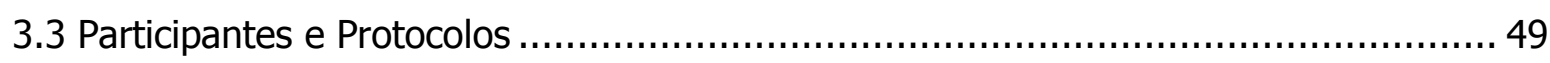

3.4 Procedimentos metodológicos na etapa de produção industrial .............................. 50

3.5 Procedimentos metodológicos para coleta de dados na etapa de projeto ….............. 50

3.6 Procedimentos metodológicos para coleta de dados na etapa de montagem ............ 50

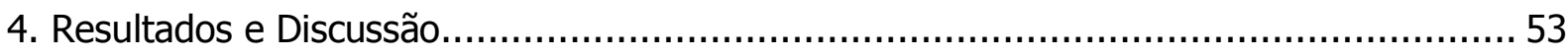

4.1 Móveis modulados componíveis: do projeto do produto à montagem ..................... 54

4.1.1 Etapa de desenvolvimento do produto ....................................................... 55

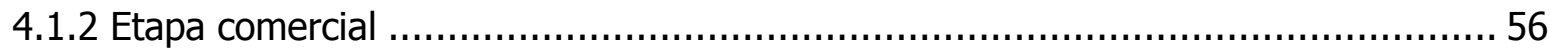

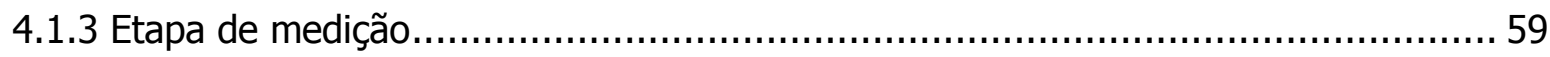

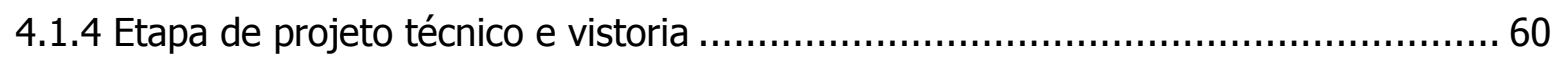

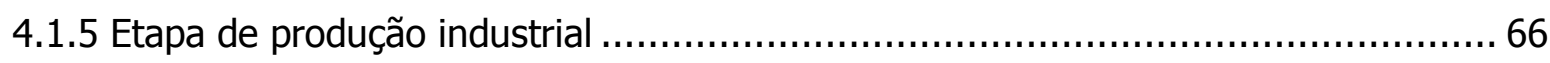

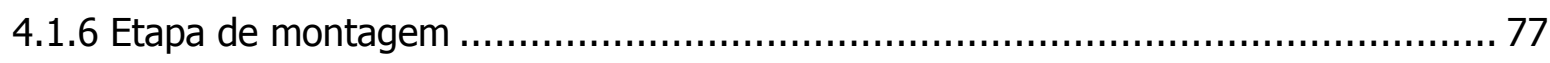

4.2 Análise dos resultados obtidos na etapa de produção industrial ............................. 79

4.2.1 Circunstâncias geradoras de descarte e tipos de materiais descartados ................. 79

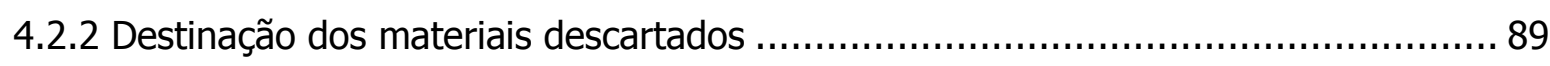

4.3 Análise dos resultados obtidos na etapa de projeto........................................... 92

4.3.1 Circunstâncias geradoras de descarte de materiais ......................................... 93

4.4 Análise dos resultados obtidos durante a montagem dos móveis ........................... 97

4.4.1 Circunstâncias geradoras de descarte e tipos de materiais descartados.................97 
4.4.2 Destinação dos materiais descartados .................................................... 107

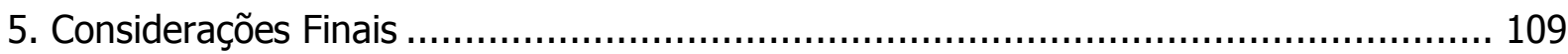

5.1 Considerações sobre a produção industrial ..................................................... 111

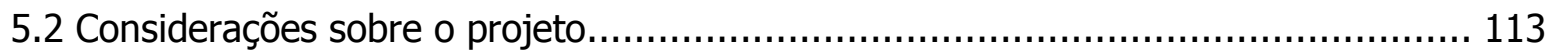

5.3 Considerações sobre a montagem ........................................................... 114

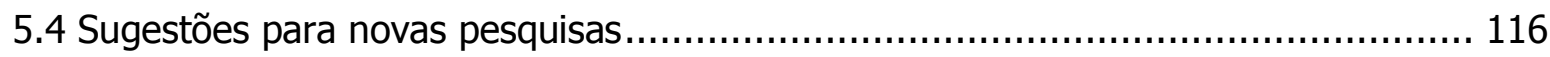

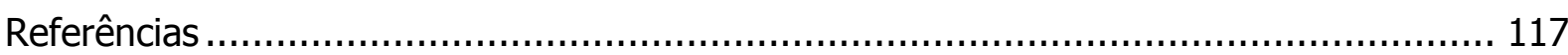

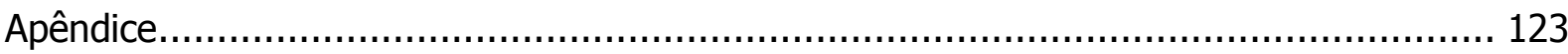


1. Introdução 
Este Capítulo refere-se à Introdução da Dissertação e será apresentada a contextualização geral da pesquisa, a sua justificativa, as delimitações do estudo, o problema central pesquisado, a apresentação dos objetivos, o geral e os específicos e as indagações exploratórias, que serviram de base para a investigação, tendo como principal referencial a relação interdisciplinar entre as áreas de design e sustentabilidade.

\subsection{Contextualização e justificativa da pesquisa}

Segundo Navarro (2006), dos tempos mais remotos aos dias atuais, toda a história e evolução do Homem estão ligados aos materiais, à sua descoberta, invenção, manipulação e uso. Desde os primeiros registros do início da civilização humana, este Homem precisou se organizar de modo a produzir tudo o que fosse necessário para garantir a sua sobrevivência e, neste sentido, a sua única fonte de matéria prima eram os materiais encontrados na natureza: o que utilizava para comer, caçar, se vestir e se proteger foi, no decorrer do tempo, artefatos produzidos por ele mesmo, de acordo com as suas necessidades, disponibilidade de recursos e condições climáticas.

É notável que no decorrer do tempo, com a modificação dos modelos econômicos, de agrário para artesanal, de artesanal para industrial, entre tantos outros fatores, esta relação do Homem com os materiais e o meio ambiente tenha se modificado consideravelmente. Para Kazazian (2005), a expansão da industrialização e a produção de bens em grande escala, para atender a demanda crescente da população são alguns dos fatores responsáveis pelos grandes problemas ambientais no decorrer do século XX e XXI.

Fuad-Luke (2009) aponta que a problemática ambiental é objeto de discussão desde 1968 quando o conceito de desenvolvimento ecologicamente sustentável foi proposto pela UNESCO, na Conferência Intergovernamental para uso e conservação racional da biosfera, sendo este evento um marco precedente na discussão de políticas públicas envolvendo sociedade e meio ambiente. Posteriormente, em 1972, em Estocolmo, na Suécia, acontece a Primeira Conferência Mundial sobre o Homem e o Meio ambiente, que buscava conscientizar os países sobre as questões ecológicas e que, vinte anos mais tarde, voltariam a se reunir na cidade do Rio de Janeiro, Brasil, para a ECO-92, a Segunda Conferência Mundial sobre o tema, em que acordos e protocolos precisaram ser estabelecidos, com metas para as nações. 
A base para o evento de 1992 foi a introdução do conceito de sustentabilidade, elaborado em 1987 pela Comissão Mundial sobre Meio Ambiente e Desenvolvimento como sendo "O desenvolvimento que atende às necessidades do presente sem comprometer a capacidade das futuras gerações atenderem às suas necessidades" (PLATCHECK, 2012, p.7), e que se fundamenta em três pilares, ambiental, social e econômico.

No Brasil, desde o início do século XX, são feitas tentativas no sentido de elaborar propostas concretas para questões relacionadas ao meio ambiente. O decreto No 8.843, de 26 de julho de 1911, que previa a Primeira Reserva Florestal do Brasil, na região do estado do Acre, foi um passo importante na busca pela preservação do meio ambiente em território nacional (BRASIL, 1911). Outros eventos e tratativas relacionados à temática ambiental ocorreram no decorrer do século XX e na passagem para o século XXI. Entre tais eventos, merece destaque a aprovação da Lei no 12.305/10, em 2010, que instituiu uma Política Nacional de Resíduos Sólidos (PNRS). Este projeto de Lei define as diretrizes relativas à gestão integrada e ao gerenciamento dos resíduos sólidos, compartilhando responsabilidade entre indústria e sociedade. Da mesma forma, define o manejo adequado no descarte dos resíduos sólidos, entendido como aquilo que tem valor econômico e pode ser reaproveitado, e dos rejeitos, o que não pode ser reciclado ou reaproveitado (BRASIL, 2016).

Pode-se afirmar que a implantação da PNRS foi um marco importante quanto às questões ambientais no Brasil, em especial no cenário contemporâneo em que a abordagem da sustentabilidade e a temática do descarte de resíduos sólidos sejam tão prementes, tendo, de um lado, os alertas sobre os custos financeiros, ambientais e sociais dos lixões e dos aterros sanitários (ABRAMOVAY, SPERANZA, PETITGAND, 2013). De outro, a proposta de novos modelos produtivos, baseados na economia circular (ELLEN MACARTHUR FOUNDATION, 2017), e no reaproveitamento dos materiais para o desenvolvimento de novos produtos, como os conceitos de cradle to cradle e upcycling, defendidos por McDonough e Braungart $(2002,2013){ }^{1}$.

\footnotetext{
${ }^{1}$ Segundo os autores, Cradle to cradle, ou Berço a berço (tradução livre do inglês), trata da utilização dos resíduos sólidos em sua forma original, respeitando as características do materiais e transformando-os em outros produtos de maior qualidade e valor, no momento de seu descarte.

A este modelo se denomina Upcycling e que difere das práticas de Recycling, de modo que a Reciclagem tem um alto custo de produção e altera a forma física dos materiais, acrescentando produtos químicos.
} 
Sob este ponto de vista, do desenho industrial e seus materiais, interesse desta pesquisa, cabe trazer aqui a abordagem de Papanek (1995), na qual o autor defende o papel ecológico do design no processo de desenvolvimento de qualquer produto, em um processo sistêmico que seja capaz de enxergar no ciclo de vida completo do produto (escolha de materiais, produção, embalagem, distribuição, uso e descarte) o equilíbrio entre as preocupações ambientais e sociais.

Da mesma forma, Manzini e Vezzoli (2011) defendem a sustentabilidade como objetivo fundamental no desenvolvimento do produto, e não como uma simples direção na tomada de decisões, ou seja, de maneira ideal, a sustentabilidade deve nascer com o projeto e não ser tratada apenas como melhorias no produto ou no processo. Quanto à visão sistêmica do design, os autores agrupam o projeto do produto industrial em cinco fases, chamadas de pré-produção, produção, distribuição, uso e descarte. Entretanto, ressaltam que o descarte de recursos materiais acontece também em outras fases, diferenciando-se em dois tipos: (1) pré-consumo e (2) pós-consumo. O descarte pré-consumo é entendido como qualquer material excedente em qualquer etapa no processo de produção. Por ser um material novo, pode retornar ao ciclo de produção, servindo de matéria prima para novos produtos. 0 descarte pós-consumo são os eliminados pelos consumidores finais e podem envolver o tratamento de resíduos sólidos e a logística reversa ${ }^{2}$, por exemplo.

Nas indústrias de móveis, por exemplo, que predominantemente utilizam painéis de madeira na produção dos produtos, segundo Claudia Dias (2015), gerente de contratos da empresa de serviços ambientais Grupo Salmeron, estima-se que somente na etapa de produção 10\% seja o percentual de descarte de materiais pré-consumo, que se torna resíduo sólido. Entretanto, conforme anteriormente exposto, sabe-se que o processo de desenvolvimento de um produto abrange outras fases, que devem ser consideradas quando se pretende traçar um panorama geral sobre o descarte de materiais em um determinado segmento de produto.

Por fim, Bonsiepe (2012) destaca certas omissões acerca da sustentabilidade dentro da metodologia projetual denominada clássica, em que certos fatores, que hoje são considerados imprescindíveis não foram abordados, como por exemplo, a contaminação ambiental, o uso de recursos não renováveis, o consumo de energia durante o ciclo

\footnotetext{
${ }^{2}$ Logística Reversa trata da recuperação total ou parcial de produtos ao seu local de origem para serem tratados de forma a minimizar os impactos ambientais no processo de descarte.

Fonte: Ministério do Meio Ambiente. Disponível em http:// www.mma.gov.br. Acesso em 08 fev. 2016
} 
completo do produto, desde sua fabricação, passando pela etapa de uso, descarte e reciclagem.

Diante do que foi exposto, surgem algumas indagações exploratórias: Uma vez que a sustentabilidade ou os aspectos ecológicos de um produto não abordados nas etapas de projeto (incluindo suas múltiplas fases), quais as consequências mais notáveis podem ser identificadas em relação ao descarte de materiais? Quais circunstâncias no sistema-produto podem ser identificadas como as mais propensas ao descarte de materiais? O que é feito com este material que, não sendo utilizando, se torna resíduo sólido?

Como recorte metodológico, o segmento de produto escolhido para esta investigação são os móveis modulados componíveis para cozinhas, que popularmente são denominados de móveis "planejados" e que tem, entre outros materiais, a madeira reconstituída, em sua variação o Medium Density Fiberboard (MDF) e o Medium Density Particles (MDP), como materiais predominantes em sua composição. Por algumas razões que serão mais bem exploradas no capítulo 2, tais como projetos personalizados, múltipla variedade de componentes e o serviço de projeto, estes móveis se inserem no segmento do varejo especializado distinguindo-se, desta forma, dos móveis populares para cozinhas vendidos por meio de rede de lojas de departamentos. Todavia, não se trata necessariamente de produtos voltados para o mercado de luxo ou de alto padrão, uma vez que grupos produtores como a Todeschini e a Unicasa possuem produtos neste segmento para as classes B e C.

De acordo com os dados do Instituto de Pesquisa e Inteligência de Mercado (IEMI, 2016), este mercado de móveis planejados no Brasil, em 2014, representava 8,8\% dentre as unidades produtoras de móveis no país, movimentando $\mathrm{R} \$ 8,9$ bilhões, em valores de produção. Deste montante, os móveis planejados para cozinhas representam $1 / 3$ do total da produção, ficando o restante a cargo dos móveis para dormitórios, estantes e escritórios (residencial e corporativo).

Composto por 4,3 mil indústrias em 2015, os móveis planejados para cozinhas foram responsáveis pela produção de 45,6 milhões de peças, tendo as lojas especializadas como principal canal de distribuição e venda. Outra estratégia de mensuração de números no setor é por meio do quantitativo de produção dos módulos, sendo este o produto responsável pela composição dos projetos. 
Segundo Homem (2015, p.145), "cerca de 5mil módulos saem mensalmente da fábrica da Kitchens", considerada uma das mais tradicionais do setor. Também, segundo dados do grupo Unicasa (2016), responsável pelas marcas Dellano, Favorita, New e Casa Brasileira, são produzidos cerca de 180 mil módulos por mês.

Desta forma, diante da expressividade deste segmento no mercado de móveis industrializados, partindo do entendimento do design como projeto, processo e visão sistêmica e à luz da preocupação contemporânea com a temática ambiental, faz parte desta Dissertação a investigação no campo do desenho industrial, em especial no segmento de mobiliário doméstico, aspectos notáveis quanto ao descarte de materiais, que não se limitem somente à produção industrial, mas buscando identificar ocorrências de geração de resíduos sólidos em outras etapas do processo, tais como nas etapas de projeto e montagem dos móveis, de modo a contribuir com a construção de um cenário geral sobre a geração de resíduos sólidos neste segmento de produto. Estas categorias conceituais são as principais referências para este trabalho.

\subsection{Problema central da pesquisa}

Que fatores considerados notáveis, a partir de um estudo qualitativo e exploratório, em termos de processos de produção, atividade de projeto e montagem de móveis modulados componíveis para cozinhas, emergem sobre o quadro atual de resíduos sólidos, predominantemente o de madeira reconstituída, em sua variação o MDF e o MDP, quanto a sua geração, características e destinação?

Buscando traçar um cenário geral sobre o tema e possibilitar o direcionamento das questões na etapa de coleta de dados, foi necessária uma divisão em subproblemas, por fontes de dados:

Que fatores considerados notáveis emergem...:

- de empresários, diretores industriais e setores de produção? (Processo de produção)

- de projetistas técnicos? (Atividade de projeto)

- de montadores? (Montagem de móveis) 


\subsection{Objetivos da pesquisa}

Esta pesquisa tem por objetivo fundamental identificar aspectos relevantes quanto ao descarte de materiais, em especial o de madeira reconstituída (MDF e MDP), no segmento de móveis modulados componíveis para cozinhas, nas etapas de produção industrial, projeto e montagem dos móveis, visando construir um panorama qualitativo do tema.

Considerando as três etapas mais representativas do processo, (1) produção industrial, (2) projeto e (3) montagem de móveis e considerando como recorte para a pesquisa o descarte dos resíduos de MDF e de MDP, entre os objetivos específicos cabe destacar:

- identificar as principais circunstâncias geradoras de descarte de materiais;

- levantar os principais tipos de materiais descartados;

- verificar como é feito a destinação do descarte deste material;

Figura 1 - Níveis sucessivos de "endereçamento" da pesquisa

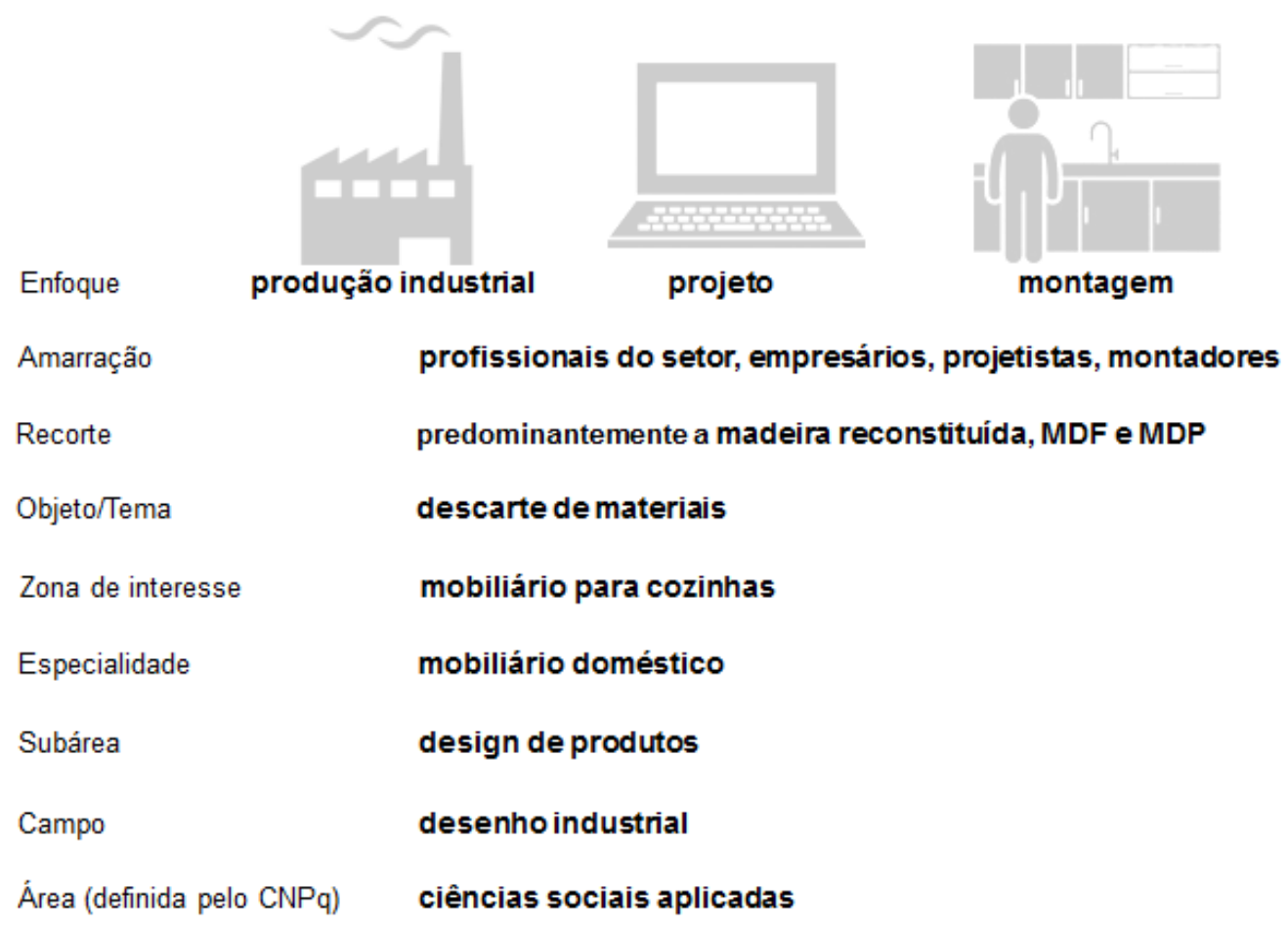

Fonte: Nascimento (2015). Diagrama elaborado pelo autor da Dissertação. 


\subsection{Delimitações da pesquisa}

Partindo da abrangência do conceito de sustentabilidade é possível perceber que muitos autores têm dedicado suas pesquisas à abordagem do tema e os seus desdobramentos em áreas do saber que, muitas vezes, ultrapassam os limites das ciências ambientais. Desta forma, a Dissertação que aqui se apresenta é o resultado de uma pesquisa realizada em design, mas que buscou na discussão contemporânea sobre a problemática ambiental estabelecer relações com o projeto de mobiliário em três fases do processo consideradas as mais representativas, como a produção industrial, o projeto e a montagem.

Assim, é importante destacar que não é objetivo da pesquisa que aqui se apresenta:

- Abordar os aspectos da operacionalização da atividade de projeto e montagem dos móveis, mas dar ênfase maior às circunstâncias geradoras do descarte de materiais.

- Desenvolver projeto de artefatos ou tipologias de objetos para o aproveitamento dos materiais a partir de material descartado;

- Elaborar propostas quanto ao tratamento dos resíduos sólidos industriais de madeira reconstituída;

- Gerar um relatório quantitativo sobre a geração de resíduos sólidos industriais;

- Propor estratégias empresariais para o cumprimento e estabelecimento dos objetivos estabelecidos na PNRS;

\subsection{Organização da Dissertação}

Esta dissertação é composta por cinco capítulos. O presente Capítulo 1 refere-se à Introdução, em que foi exposta a contextualização geral da pesquisa, a sua justificativa, as delimitações do estudo, o problema central pesquisado, a apresentação dos objetivos, o geral e os específicos e as indagações exploratórias, que serviram de base para a investigação, tendo como principal referencial a relação interdisciplinar entre as áreas de design e sustentabilidade.

No Capítulo 2 foi elaborada a fundamentação teórica, partindo de cinco abordagens: histórica, destacando-se os aspectos mais representativos quanto ao espaço da cozinha e os estudos sociais que contribuíram para a melhor organização projetual deste ambiente da 
casa no decorrer do século XX. Quanto aos materiais, especial atenção é dada à madeira reconstituída, reconhecida a sua importância no contexto produtivo industrial e por esta razão escolhida como recorte da investigação. Do ponto de vista de projeto, buscou-se estabelecer relações entre o projeto da cozinha contemporânea e o mobiliário que o compõe. Do ponto de vista do produto, apresentam-se os principais conceitos, definições, aplicações e características do móvel modular componível para cozinhas.

O Capítulo 3 apresenta os procedimentos metodológicos utilizados na pesquisa. Neste capítulo descreve-se a abordagem de pesquisa utilizada, o objeto de estudo, as fontes de dados, as técnicas utilizadas para coleta de dados e as técnicas utilizadas no seu tratamento. Finaliza-se com uma síntese da estrutura metodológica por meio de um quadro sinóptico.

O Capítulo 4 apresenta os resultados tratados buscando-se responder aos problemas e subproblemas levantados no início da investigação, por meio dos padrões recorrentes identificados na análise dos dados.

O Capítulo 5 trata das Considerações Finais, a apresentação das contribuições dos resultados para o campo do design de produtos, discussões complementares acerca do tema e sugestões para futuras pesquisas. 
2. Fundamentação Teórica 
Neste Capítulo foi elaborada a fundamentação teórica, partindo de cinco abordagens: histórica, destacando-se os aspectos mais representativos quanto ao espaço da cozinha e os estudos sociais que contribuíram para a melhor organização projetual deste ambiente da casa no decorrer do século XX. Quanto aos materiais, especial atenção é dada à madeira reconstituída, reconhecida a sua importância no contexto produtivo industrial e por esta razão escolhida como recorte da investigação. Do ponto de vista de projeto, buscou-se estabelecer relações entre o projeto da cozinha contemporânea e o mobiliário que o compõe. Do ponto de vista do produto, apresentam-se os principais conceitos, definições, aplicações e características do móvel modular componível para cozinhas.

\subsection{O espaço da cozinha}

Segundo Lemos (1978), de todos os ambientes da casa paulista, a cozinha é possivelmente o espaço que mais sofreu alterações em tamanho e uso no decorrer do tempo, ocasionadas principalmente por fatores como a influência da colonização portuguesa, a abolição da escravidão e a urbanização das cidades, destacando-os como momentos marcantes e que definiriam os rumos da cozinha moderna. A estes fatores, Verissimo e Bittar (1999) acrescentam a influência dos hábitos e costumes norte americanos como um vetor das mudanças ocorridas neste ambiente da casa brasileira, mudanças estas relacionadas à racionalização das tarefas domésticas e à disponibilidade de tecnologia, que impulsionou o surgimento de novos materiais e eletrodomésticos, adequados aos hábitos contemporâneos do comer e do cozinhar.

Historicamente, Silva (2008) aponta que ainda na segunda metade do século XIX, nos Estados Unidos, as mudanças sociais advindas da abolição da escravidão e consequente ausência de empregados para realização das atividades em casa fizeram surgir a preocupação com a organização do trabalho doméstico. Segundo o autor, os primeiros estudos desta natureza foram desenvolvidos pela educadora Catherine Esther Beecher (apud SILVA, 2008, p.95-96), que publicou em 1841 um tratado sobre economia doméstica. 0 objetivo de sua pesquisa era organizar as atividades em casa e as tarefas na cozinha de forma racional, semelhante ao trabalho desempenhado nas fábricas. Em 1869, ela publica outro estudo no qual analisava a importância do planejamento da cozinha, com o estabelecimento das funções e superfícies de trabalho, de forma a facilitar as atividades executadas pelas donas de casa. 
Alguns anos mais tarde, também nos Estados Unidos, a arquiteta Christine Frederick inicia estudos de gerenciamento do tempo, aplicado às tarefas domésticas. Em 1912 publica o "Estudo do Fio", o qual media o percurso para a realização das tarefas dentro do espaço de uma cozinha, propondo, como resultado, uma cozinha menor, setorizada e funcional. (WEY, 2007). Influenciada por estes estudos, a arquiteta vienense Margarete Schütte Lihotzky, em colaboração com o arquiteto Ernest May, e inspirados pelo alto desempenho das atividades de trabalho em cozinhas compactas de navios de guerras alemães, projetam, em 1926, a Cozinha de Frankfurt. Este projeto nasce com a proposta de reconstrução da cidade de Frankfurt, na Alemanha, que enfrentava graves problemas sociais e econômicos, frutos da primeira grande guerra (BARBOSA, 2007).

Neste cenário, a organização da cozinha era fundamental, de modo a favorecer a execução das tarefas e liberar as mulheres para o mercado de trabalho. 0 modelo proposto pela Cozinha de Frankfurt consistia em uma cozinha compacta e modular, com os armários setorizados por atividades e funções e com local pré-estabelecido para fogão, pia e armazenagem de louças e alimentos.

Figura 2 - Foto divulgação da "Cozinha de Frankfurt"

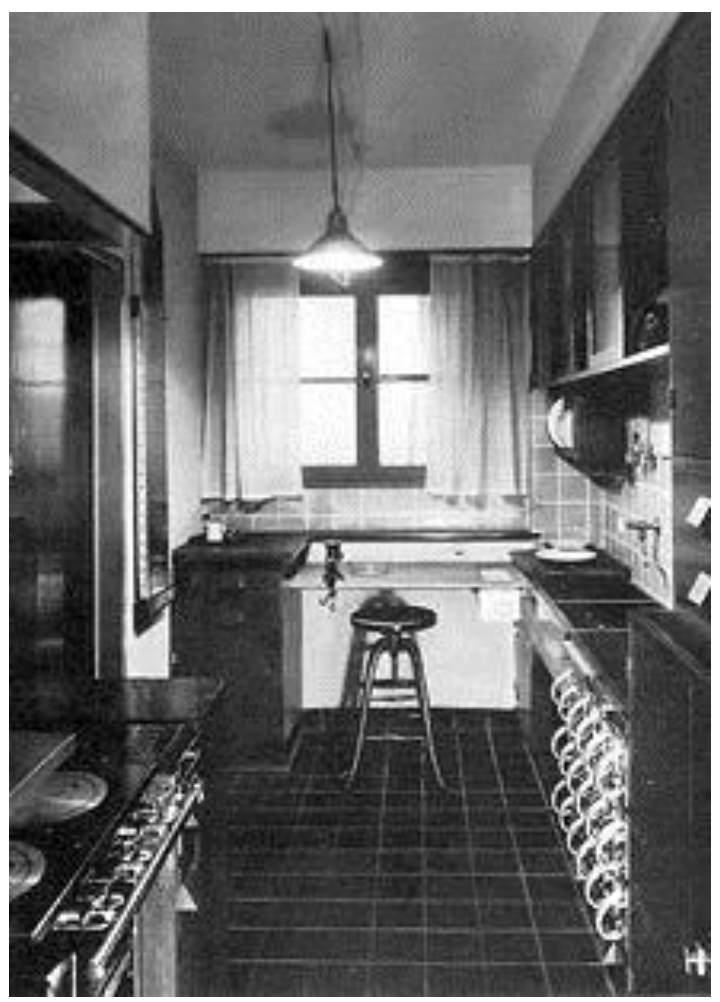

Fonte: http://www.museumsportal-berlin.de/de/magazin/blickfange/die-frankfurter-kuche-von-margareteschutte-lihotzky/. Acesso em: 14 jun. 2015. 
Figura 3 - Planta da Cozinha de Frankfurt com a aplicação do Estudo do Fio (á direita)

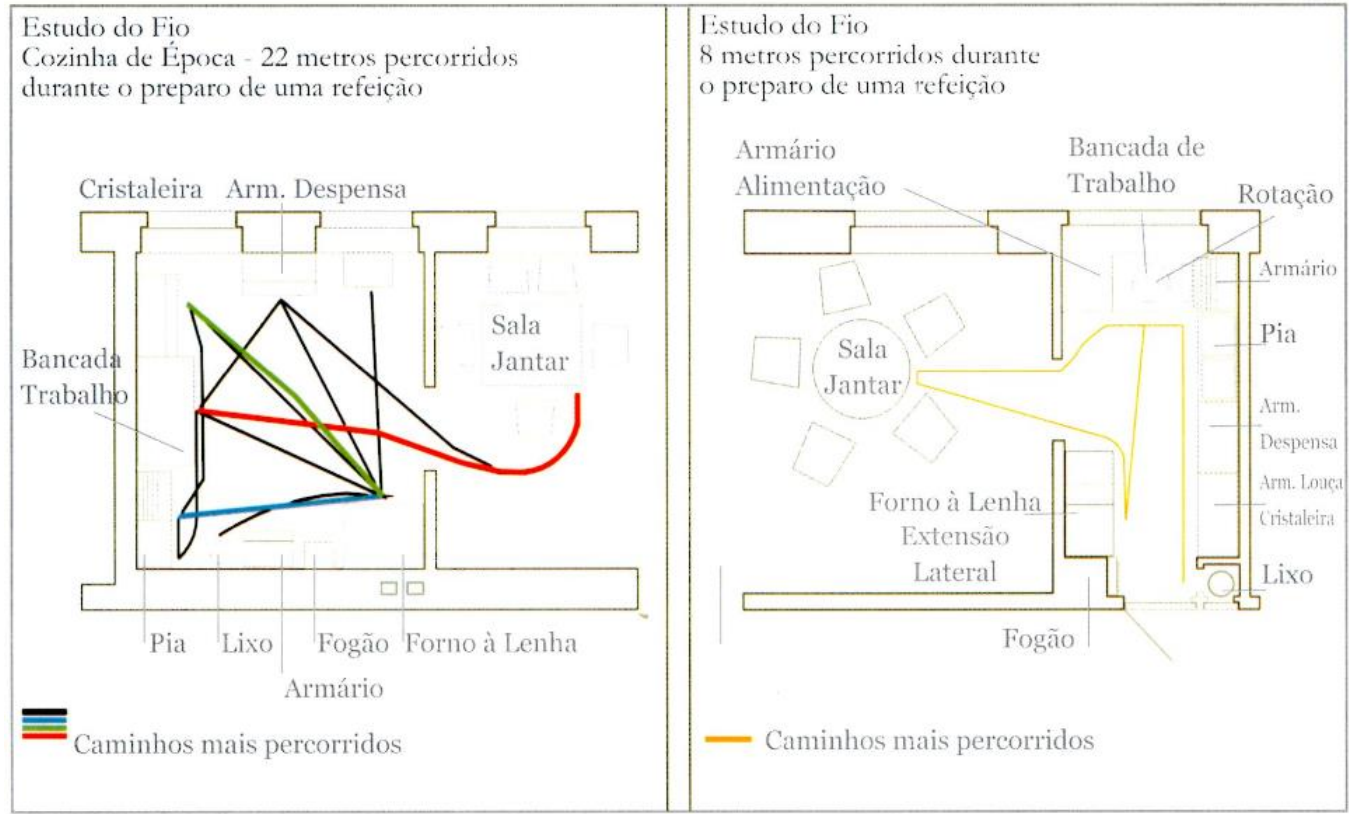

Fonte: Wey (2007, p.37).

No Brasil, Homem (2015) destaca que, em 1938, o arquiteto Henrique Mindlin publicou um artigo intitulado "Análise Racional do Projeto - Método Klein", o qual dividia a cozinha em três grandes centros de atividades, denominados armazenagem, lavagem e cocção, distribuídos conforme o percurso para a realização das atividades.

Figura 4 - Configuração triangular de trabalho em uma cozinha

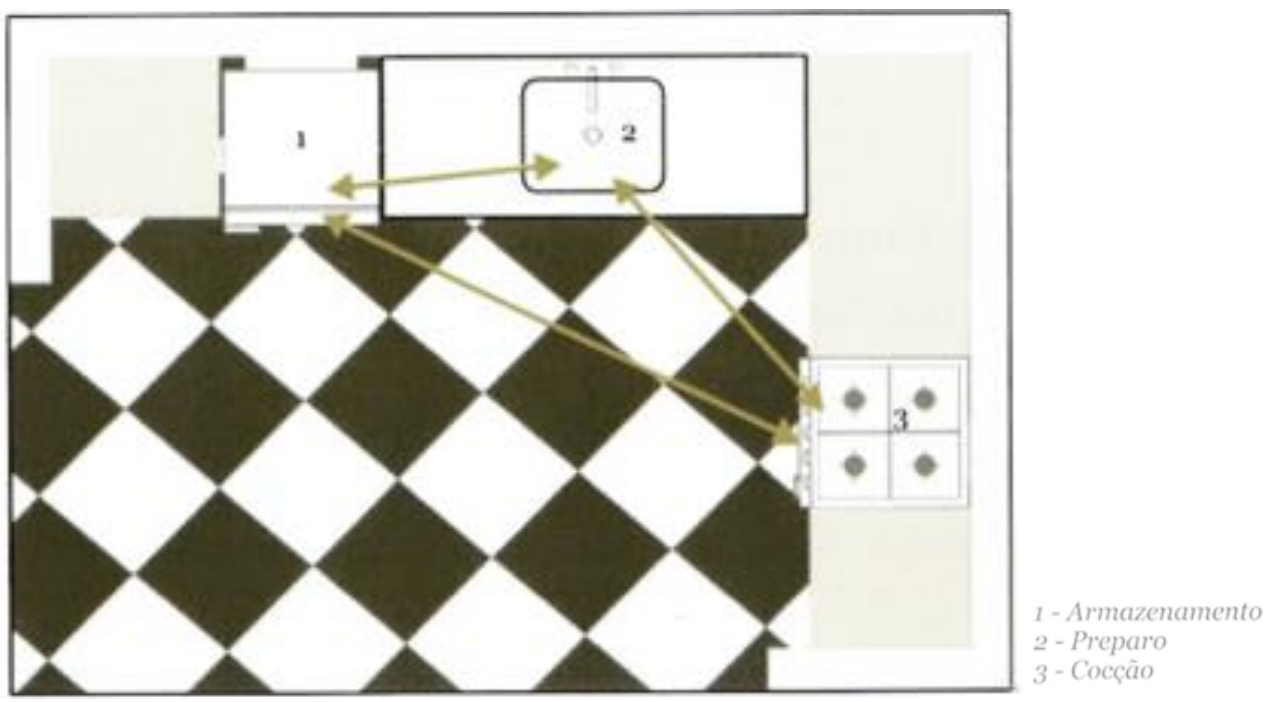

Fonte: Wey (2007, p.41). 
Segundo a autora, este estudo foi incorporado pelos alunos da Escola Politécnica de São Paulo, que analisaram plantas de cozinhas domésticas norte americanas, aplicando progressivamente estes princípios de racionalidade em novos projetos, definindo-os como parâmetros para uma disposição mais adequada dos móveis, tendo os três centros de atividades conectados entre si, criando superfícies contínuas de trabalho.

Figura 5 - "Organização racional da cozinha", proposto por Henrique Mindlin em 1938

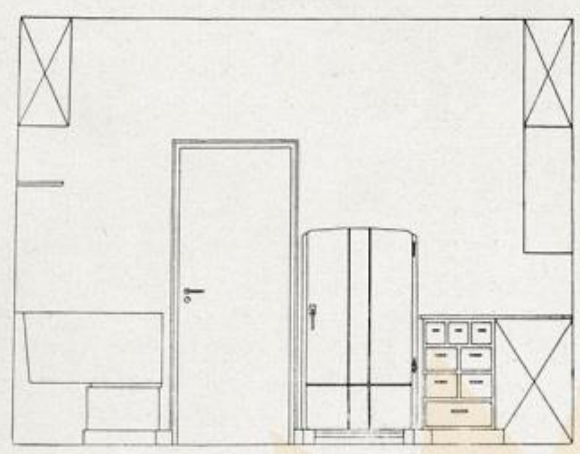

Vista A

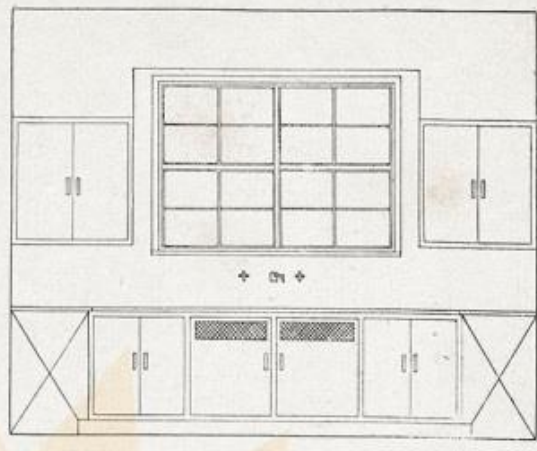

Vista B
- Geladeira

2. Despensa

3. Mesa de serviço com armario na parte in-

ferior.

4. Pia

5 - Despejo

6 - Fogão

7. Armarios para louça de uso diario

8 - Armarios e deposito

9 e 10 Banco e mesa para refeiçõas rapidas e de empregadas
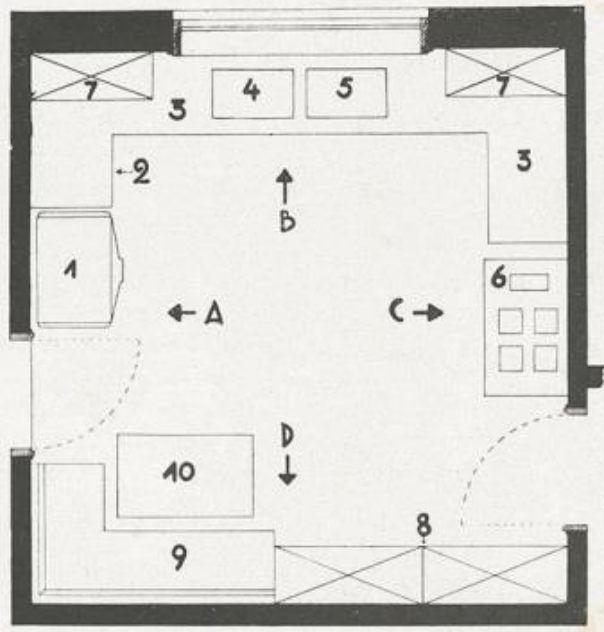

Planta

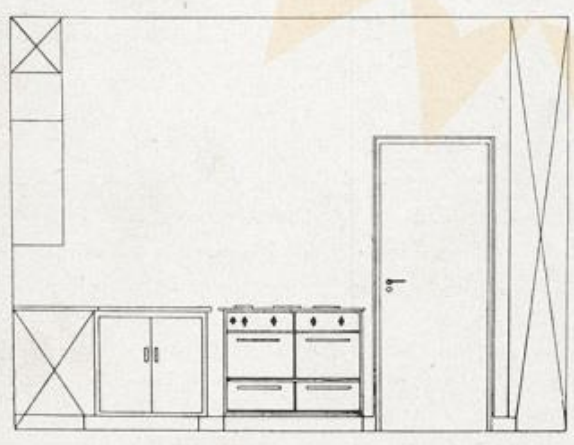

Vista C

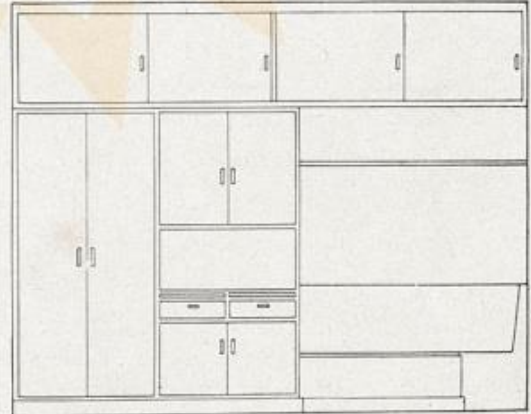

Vista D

Fonte: Mindlin (1938, p.21). Disponível em http://www.acropole.fau.usp.br/edicao/2. Acesso em: 04 jan. 2017 
No seu estudo, o arquiteto Mindlin (1938) discorre detalhadamente sobre as funções a serem desempenhadas e as dimensões mínimas exigidas por cada centro de atividade, definindo, inclusive, o quantitativo de louças e utensílios. Defende a importância do planejamento da cozinha ainda na etapa de projeto, apontando que o projeto racional da cozinha permite a concepção de espaços menores, reduzindo, assim, o custo da construção e transformando a cozinha, de um local "feio e desagradável", em algo convidativo, elevando o nível do trabalho caseiro e um conforto compatível com o progresso material daquele período.

É interessante notar que no decorrer do seu artigo, ainda que o arquiteto Henrique Mindlin não mencione diretamente, é possível perceber a forte influência de estudos precedentes, como os conceitos definidos no Estudo do Fio e no da Cozinha de Frankfurt, que podem ser identificados como bases para a sua análise.

Certamente, estes estudos sobre a organização do trabalho doméstico no século $X X$, que tinham como prioridade buscar a eficiência na realização das tarefas, foram decisivos para a configuração projetual das cozinhas modernas e, consequentemente, no desenvolvimento de produtos para compor estes espaços. Moraes (1999, p.37) destaca a importância da cozinha no sucesso dos produtos industriais como um verdadeiro laboratório em que "dezenas de produtos eram testados em nome da praticidade, da higiene, do conforto, da agilidade e da segurança de uso".

Da mesma forma, no contexto brasileiro, a influência da Semana de Arte Moderna em 1922, que foi um marco histórico na busca pela modernização em diversas áreas, entre elas a arquitetura, trouxe a proposta de novos arranjos nos interiores domésticos alinhados com a nova arquitetura vigente. Também, segundo Cardoso (2008), durante a segunda guerra mundial, a indústria nacional se expandiu significativamente para atender demandas locais de produtos que até então eram importados da Europa, fator que impulsionou nas décadas subsequentes a produção de móveis neste segmento, por conta da disponibilidade no mercado dos insumos para produção dos armários, como os revestimentos laminados da Fórmica e as empresas produtoras de painéis de compensado, como a Duratex, por exemplo. (Wey, 2007). 


\subsection{A madeira e o mobiliário para cozinha}

Quanto ao emprego da madeira na produção de móveis no Brasil, Lima (2006) afirma que esta tradição deve-se ao fato da madeira constituir o mais antigo material utilizado pelo homem, sendo até hoje explorada pela facilidade de obtenção e pela flexibilidade com que permite ser trabalhada, somando-se a isto o fato de que o Brasil possui a maior superfície de floresta tropical do mundo (LEITE, 2001) e ao passado colonial brasileiro, com a herança portuguesa de utilização de madeira no mobiliário (SANTOS, 2015). Entretanto, como se trata de um recurso natural, alguns fatores contribuíram para a gradativa substituição das placas de madeira natural por painéis de compensado.

Primeiro, na relação entre produção e demanda percebe-se que a madeira como recurso natural é um bem esgotável. Da mesma forma, a madeira em sua forma natural não é um material homogêneo, está sujeita a empenos e principalmente à variação de cor e forma, características não tão favoráveis à industrialização.

Para resolver tais problemas de padronização, no início do século $X X$, nos Estados Unidos, a tecnologia empregada no uso da madeira propicia a fabricação de painéis de compensado, processo em que lâminas de madeira nativa são sobrepostas e compensadas entre si, com o sentido dos veios da madeira posicionados de forma invertida, processo que garante estabilidade dimensional ao produto final (LIMA, 2006). Segundo Franco (2010, p.33), o compensado "teve suas primeiras patentes registradas por volta de 1870 , tendo, no entanto, demanda comercial a partir do início do século XX", utilizado principalmente na produção de mobiliário em série.

O autor aponta certa defasagem de três décadas na produção destes painéis no Brasil em comparação com os produtores internacionais, destacando o início da produção do compensado no país por volta de 1940, da chapa de fibra em 1955, do aglomerado em 1966 e do MDF somente em 1997 (FRANCO, 2015, p.25).

Cabe destacar que a madeira natural era o material utilizado na produção dos painéis em compensado e, ainda que vencidos os problemas de padronização, os problemas ecológicos do uso da madeira precisariam ser solucionados. 
Segundo dados do Sistema Nacional de Informações Florestais (SNIF, 2016) ${ }^{3}$, a alternativa para substituir a demanda da madeira nativa foi o plantio de florestas, introduzido em 1903 pelo engenheiro agrônomo Edmundo Navarro de Andrade, quando trouxe ao país as primeiras mudas de eucalipto, que se adaptaram bem aos cerrados paulistas assim como as mudas de pinus (1947) com bom desenvolvimento no sul brasileiro.

Na década de 70, a política de incentivos fiscais para o reflorestamento foi a responsável pelo crescimento da silvicultura no país e assim, entre as décadas de 80 e 90, o uso dos painéis em madeira reconstituída na indústria, em suas variações o MDF e o MDP, foi um passo importante na redução do emprego de madeiras nativas, no aproveitamento da madeira e na produtividade das indústrias moveleiras no Brasil (LIMA, 2006). Talvez por esta razão, atualmente são raros os casos de indústrias do segmento que ainda utilizam o compensado na sua produção.

O conceito de madeira reconstituída está diretamente ligado ao fato de que se trata de um material industrial processado, em que à madeira é adicionado algum tipo de resina para a formação de painéis. No Brasil, destacam-se como empresas produtoras destes painéis, Duratex, Masisa, Berneck, Fibraplac, entre outras. Estes painéis, de MDF e MDP, são produzidos em pinus ou eucalipto, de árvores provenientes de áreas de reflorestamento, certificadas pelo Forest Stewardship Council (FSC) ou Conselho de Manejo Florestal' ${ }^{4}$

Segundo o SNIF, a importância da função das florestas plantadas não está somente na diminuição da pressão sobre as florestas nativas, mas entre outros aspectos, no reaproveitamento das áreas degradadas pela agricultura e pecuária e em uma maior homogeneidade da matéria prima.

\footnotetext{
${ }^{3}$ Disponível em: http://www.florestal.gov.br/snif/recursos-florestais/as-florestas-plantadas. Acesso em 28 dez. 2015

${ }^{4}$ Tradução livre do inglês.
} 
Figura 6 - Diagrama da produção dos painéis em madeira reconstituída
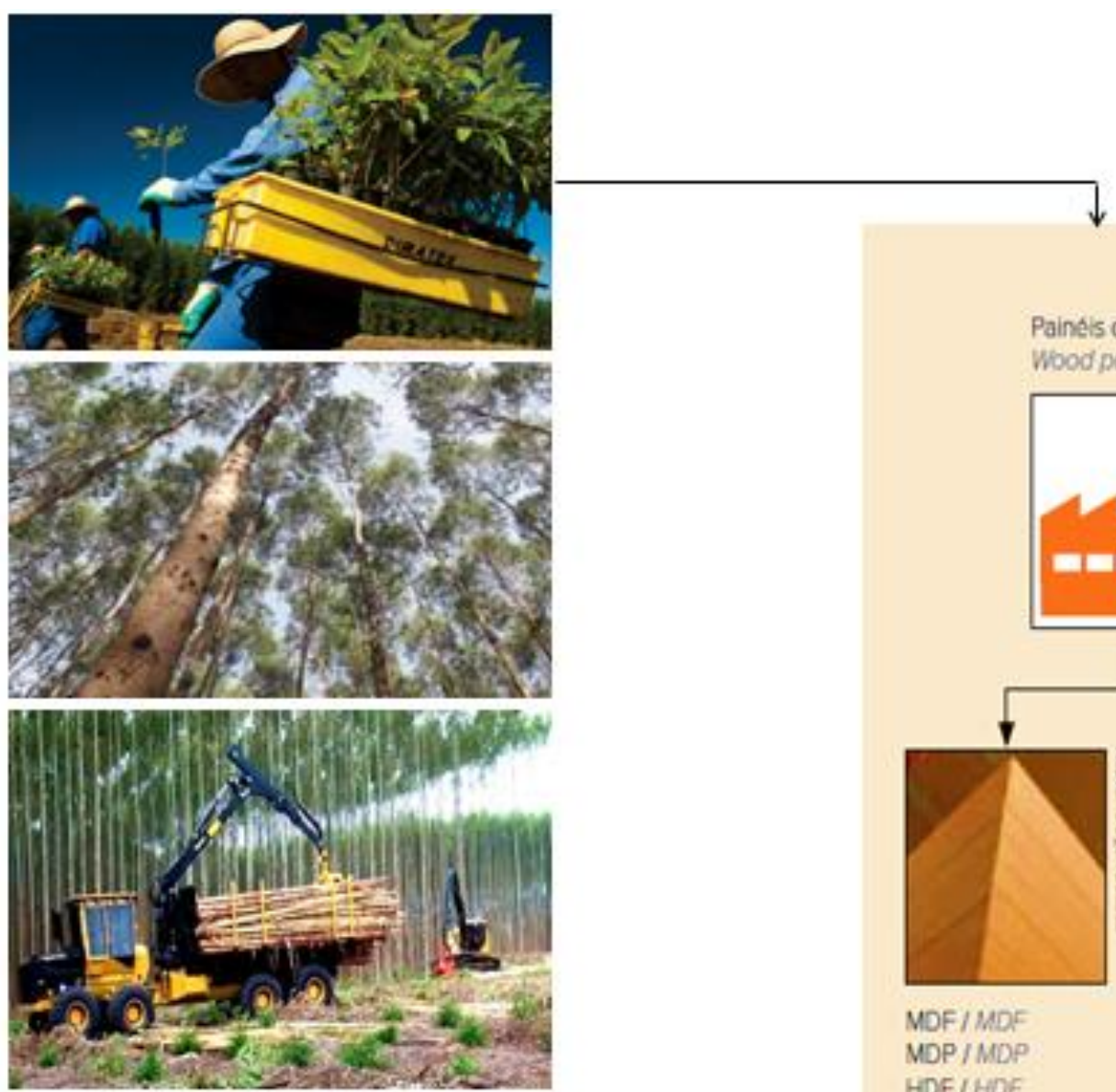

Painels de madeira

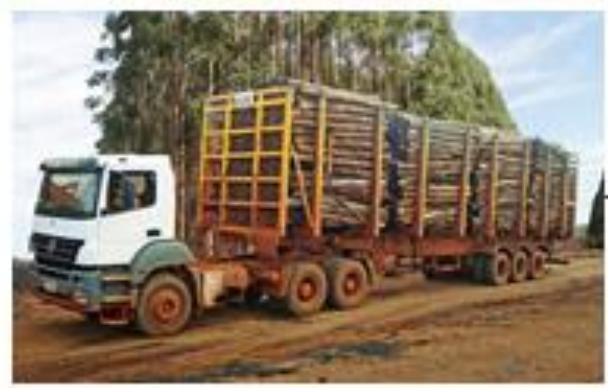
Wood pancts

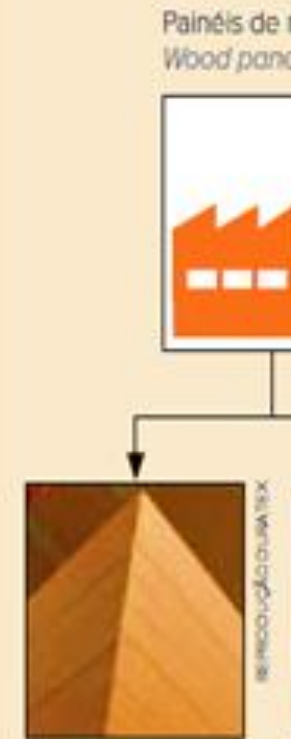

MOF/MDE MDP /MDP HDF /HDF Harobourd Hordboard

Fonte: Cartilha IBA, 2015. Disponível em http://iba.org/images/shared/iba_2015.pdf. Acesso em: 28 dez. 2015 e http://www.duratexmadeira.com.br/ Acesso em: 08 fev. 2016. Diagrama elaborado pelo autor da Dissertação.

Como ilustrado na figura acima, de acordo com a Indústria Brasileira de Árvores (IBA, 2015), a produção destes painéis de madeira englobam as seguintes etapas:

- Identificação de áreas disponíveis;

- Preparo do solo;

- Seleção das mudas de pinus e/ou eucalipto;

- Plantio e manutenção;

- Crescimento das árvores plantadas (aproximadamente 7anos); 
- Colheita;

- Transporte das toras até as indústrias produtoras de painéis;

- Processamento industrial das toras de madeira, responsável pela produção de painéis de MDF, MDP e produtos para outros setores da economia, como o de pisos laminados, por exemplo;

Por definição, o MDF é um painel de fibras de madeira média densidade, que são aglutinadas com resina sintética termofixa e se consolidam sob a ação conjunta de pressão e calor, resultando em um painel maciço e liso, de múltiplas espessuras. (MASISA, 2016).

Figura 7 - Painéis de MDF sem revestimento e com espessuras variadas

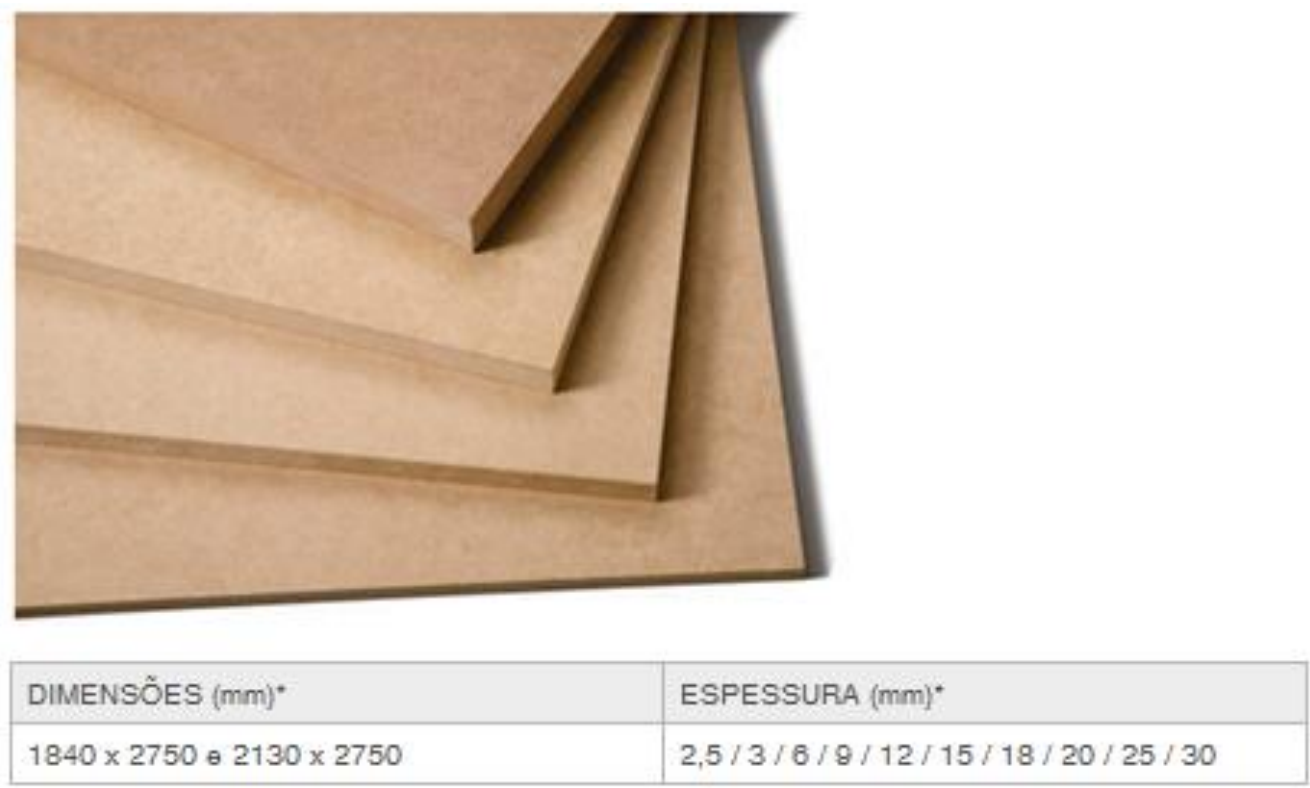

Fonte: http://www.duratexmadeira.com.br/paineis-mdf/D55. Acesso em: 08 fev.2016.

O painel de MDP tem o mesmo princípio de produção, porém ao invés de utilizar-se de fibras, na produção dos painéis de MDP utilizam-se partículas de madeira, resultando em uma superfície com acabamento final poroso. Visualmente os painéis de MDP são parecidos com o que se conhece por aglomerado, denominação em desuso nos últimos anos, devido à fama ruim que o material teve no início de sua utilização, em que as ferragens especificadas em projeto (tais como parafusos, dobradiças, corrediças, etc.), utilizadas na composição dos produtos, não eram adequadas à sua superfície porosa, o que naturalmente resultou em móveis de baixa durabilidade. 
Figura 8 - Painéis de MDP sem revestimento e com espessuras variadas

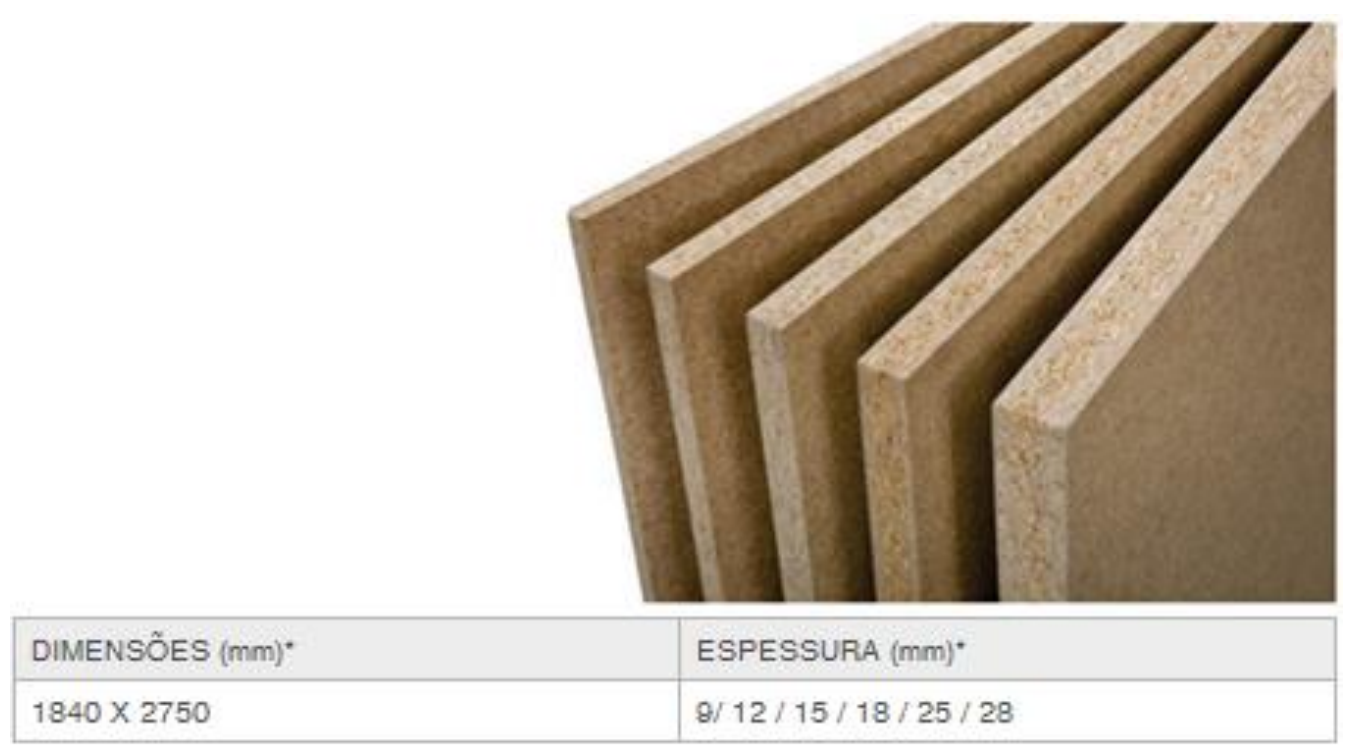

Fonte: http://www.duratexmadeira.com.br/paineis-mdp/D69. Acesso em: 08 fev.2016.

Somado às especificidades técnicas de cada material, a principal diferença entre os dois materiais é a aplicação a qual se destinam. Segundo a empresa Masisa, os painéis de MDP, produzidos à base de partículas, são mais leves, garantem maior estabilidade ao produto final e são indicados para a estrutura dos móveis, enquanto os painéis de MDF, por conta da superfície lisa, são mais indicados para usinabilidade e acabamentos. Exemplos de usinagem podem ser considerados rebaixos, desenhos, molduras ou mesmo um detalhe de puxador, tipo cava, por exemplo, realizados sobre o MDF em seu aspecto natural, superfície que, após a usinagem é pintada, para efeito de acabamento, melhoria de desempenho e qualidade estética.

De qualquer forma, quando utilizados próximos de áreas suscetíveis à umidade, como as cozinhas, por exemplo, tanto os painéis de MDF quanto os de MDP precisam ser revestidos, para efeitos de acabamento e principalmente proteção da superfície. Atualmente, no catálogo de produtos das indústrias processadoras de madeira é possível encontrar variadas opções de revestimentos para a superfície destes painéis e, em algumas indústrias, opções até para a composição interna (miolo) do painel.

No caso da indústria Duratex ${ }^{5}$, por exemplo, o MDF pode ser comercializado no seu aspecto natural e em mais quatro opções: revestido em laminado de baixa pressão (BP), PD (pintado de um lado da superfície), antichamas, e na opção denominada Ultra, com o miolo

\footnotetext{
${ }^{5}$ Informações obtidas por meio do site <http://duratexmadeira.com.br> Acesso em: 07 jan. de 2017.
} 
identificado pela cor verde, que segundo o fabricante, o torna mais resistente à umidade e aos cupins. Na mesma indústria é possível encontrar no portfólio de produtos a oferta do MDP em seu aspecto natural, laminado BP e "finishing foil", identificado pela sigla FF. ${ }^{6}$

Figura 9a e 9b - Modelos de portas de armários para cozinhas produzidas em MDF

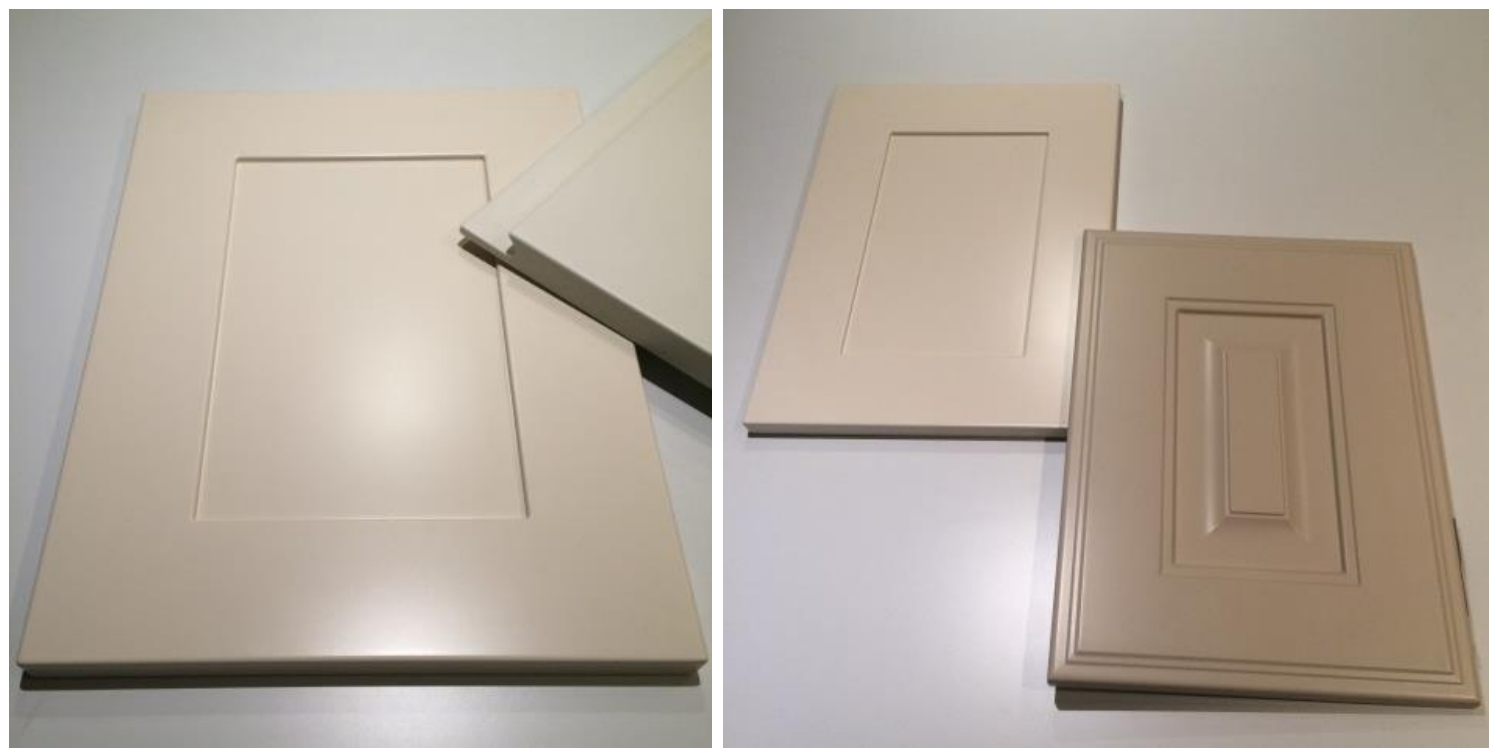

Fonte: Arquivo do autor.

A esta variedade de opções, no caso da compra de grandes lotes, ainda há a possibilidade da criação de estampas exclusivas, de acordo com o lançamento de novas cores e coleções, geralmente definidas pelas equipes de marketing e design das indústrias moveleiras.

Assim, diante de tamanha oferta de produtos, seja qual for o revestimento da superfície, as indústrias de móveis compram os painéis de madeira já revestidos das indústrias produtoras dos painéis, o que economiza tempo de produção dos módulos nas indústrias moveleiras. $\mathrm{A}$ exceção quanto ao fornecimento dos painéis revestidos, conforme exposto anteriormente, é no caso do MDF, quando esta superfície irá se submeter à personalização por meio de pintura e/ou usinagem.

Por questões relacionadas ao uso do produto, no caso das indústrias de móveis modulados para cozinha, o revestimento laminado é o mais utilizado. Este revestimento laminado é um processo em que são aplicadas, sobre os painéis de madeira, camadas de papel decorativo

\footnotetext{
${ }^{6}$ Finishing Foil ou "folha de acabamento" (tradução livre do inglês) é um revestimento de superfície produzido através da pintura de bobinas de papel que reproduzem cores, desenhos e estampas pelo sistema de pintura em rotogravura ou flexogravura. Após pintado, o papel recebe um acabamento e para obtenção do resultado final, estas folhas de papel são prensadas sobre a superfície da madeira, MDF ou MDP (AKZO NOBEL, 2017).
} 
com resinas melamínica e fenólicas (MADEPAR, 2016), resultando no que comercialmente é chamado de laminado de alta pressão (AP) e no laminado de baixa pressão (BP), este último com menos camadas de revestimentos.

No segmento de mobiliário é possível encontrar os dois tipos de laminação - o mais comum é o uso do laminado AP em superfícies visíveis, como portas e frentes de armários e o laminado BP como revestimento da superfície interna dos armários, o que traz uma economia representativa ao custo final do produto. Da mesma forma, como ilustrado na figura abaixo, os revestimentos laminados AP e BP podem ser aplicados tanto sobre os painéis de MDF quanto de MDP.

Figura 10 - Processo de aplicação de revestimento laminado sobre os painéis de madeira

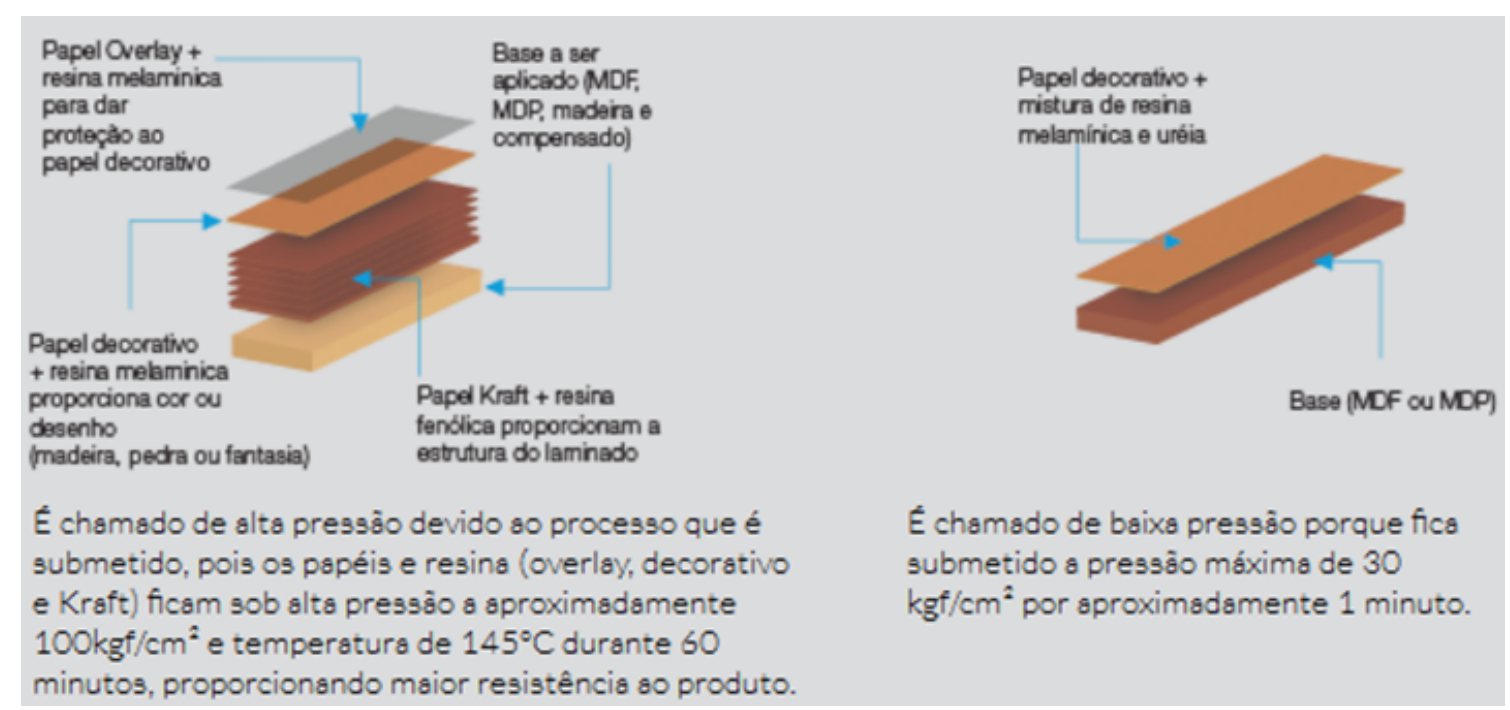

Fonte: http://www.madepar.com.br/Content/13-laminados-de-alta-pressao. Acesso em: 08 fev. 2016.

Ainda que não seja o objetivo direto deste estudo, é possível identificar no segmento de móveis para cozinha o uso em menor proporção do vidro, como revestimento para portas e frentes de gavetas. $E$ pode se concluir também que, enquanto resultado de um processo, 0 revestimento dos painéis de madeira assemelha-se ao que Löbach (2001) chamou de funções dos produtos industriais: práticas, quanto à proteção da superfície, permitindo maior durabilidade; estéticas, quanto ao acabamento final, em oposição ao seu aspecto natural pós-produção e simbólicas, destacando-se o predomínio das estampas madeiradas, com padrões e texturas cada vez mais próximas do aspecto natural da madeira - sem contar os lançamentos de revestimentos laminados em padrões e texturas simulando superfícies de pedras, tecidos e metais, como possível alternativa à substituição destes materiais originais. 
Evidentemente, a escolha entre os tipos de painéis, seus revestimentos e suas espessuras varia de acordo com cada indústria moveleira e de seu posicionamento no mercado e, neste sentido, os materiais acabam sendo um importante fator na distinção entre empresas concorrentes.

Figura 11 - Composição de cozinha com três tipos de acabamentos laminados

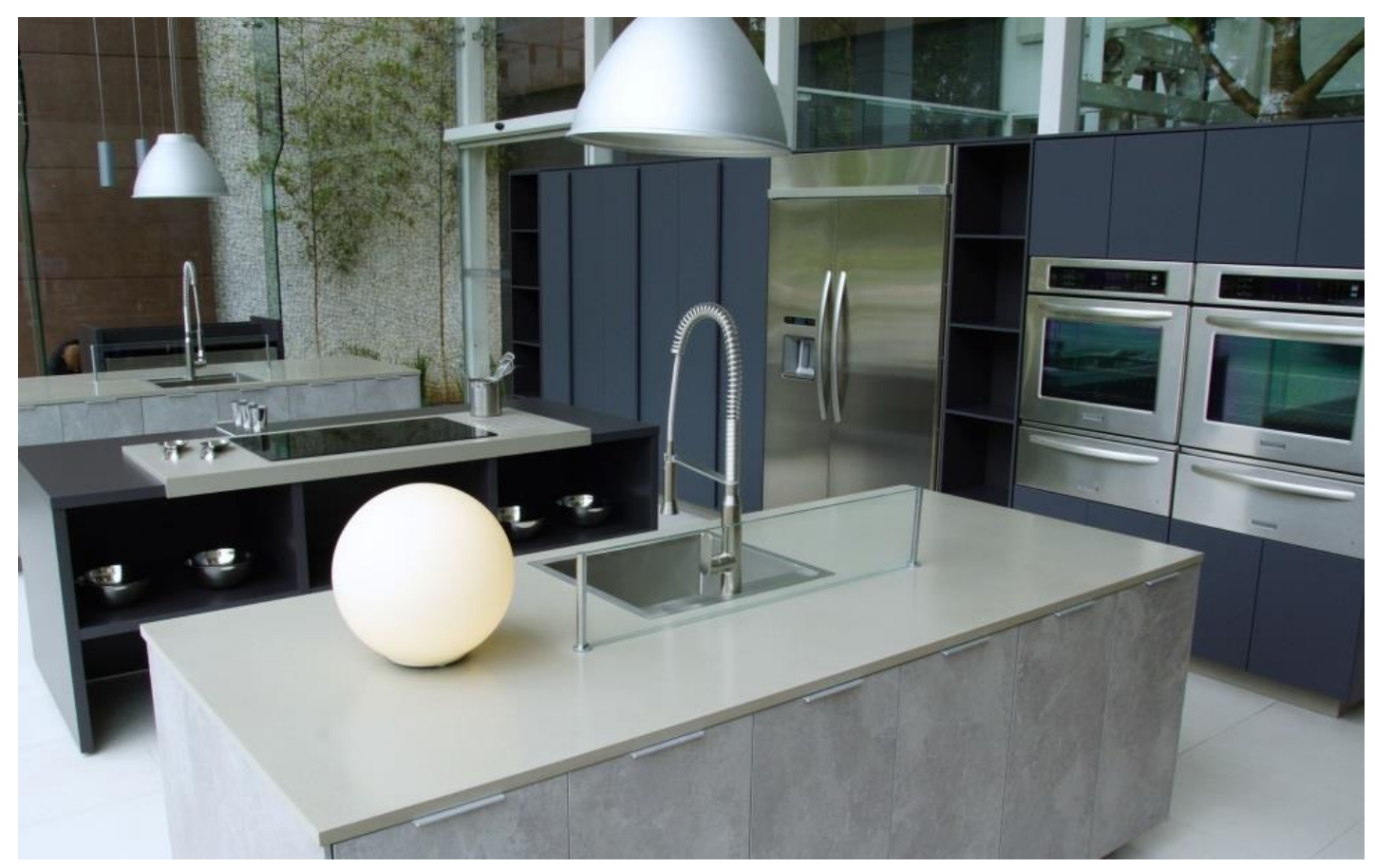

Fonte: http://www.kitchens.com.br/cozinha.php. Acesso em: 07 jan. 2017.

Pode-se afirmar que a combinação destes dois materiais, painéis industrializados de madeira e revestimentos laminados, disponíveis no Brasil por volta de década de 1950, foi um fator decisivo para o fomento da indústria de móveis componíveis para cozinhas e, por se tratar de um material mais econômico e homogêneo, torna-se favorável o seu uso na produção de móveis em grande escala, consequentemente, na produção dos módulos que irão compor o projeto da cozinha.

Da mesma forma, de acordo com Franco (2015) representou uma nova forma de conceber o produto, uma vez que as características destes materiais só permitiam formas planas e retilíneas, favoráveis à industrialização, contrapondo com as formas curvas e torneadas dos móveis em madeira maciça, até então em vigor. 


\subsection{Modulados componíveis para cozinha}

Nos Estados Unidos, no início do século $\mathrm{XX}$, com a opção no mercado dos painéis em compensado (abordada anteriormente), a modularidade se tornou uma nova maneira de se pensar e produzir o móvel. Esse novo conceito nasce inspirado pelo princípio de padronização - condição fundamental para a produção industrial em série - que é transposto do insumo básico à unidade manufaturada, possibilitando a construção de unidades tridimensionais de área padronizada: os módulos. A mesma lógica utilizada para a padronização dos insumos da indústria é aqui utilizada para construir unidades independentes com diferentes funções, mas que obedecem a uma mesma razão construtiva e a um denominador comum que as tornam compatíveis e intercambiáveis, permitindo que sejam arranjados e combinados de modo flexível para atender a diversas necessidades e espaços (HESKETT, 2006). Segundo o autor, o primeiro registro de um sistema pré-modular foi desenvolvido pelo empresário norte americano Otto Wernicke, em 1880.

Figura 12a - Registro de uma das patentes das estantes de Otto Wernicke, de 1892. (esquerda) Figura 12b - Cartaz de divulgação das estantes de Otto Wernicke. (direita)
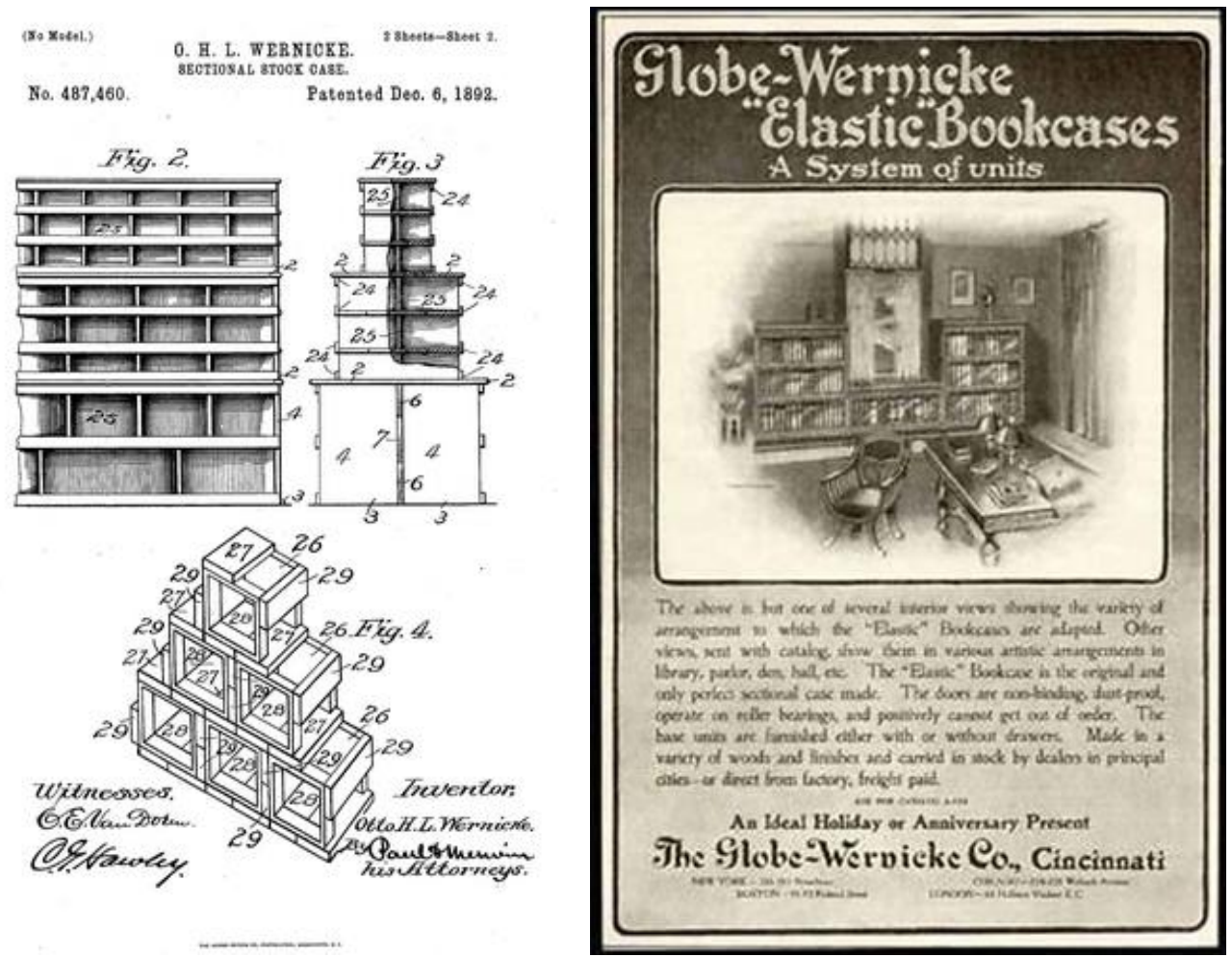

Fonte: http://www.pensapedia.com. Acesso em: 14 jun. 2015. 
O projeto que Wernicke desenvolveu consistia em uma série de unidades intercambiáveis feitas de painéis de madeira em dimensões pré-definidas e que possibilitavam a montagem de diferentes estantes, denominadas por seu criador de "estantes elásticas". Na figura anterior é possível perceber a lógica de industrialização relacionada ao projeto do móvel. Uma mesma peça numerada poderia ser usada em variadas partes do produto, o que possibilitaria múltiplas composições "personalizadas", conforme as aspirações do cliente, característica valorizada no cartaz de divulgação. Ainda, segundo Heskett, empresas alemãs e americanas de armários para cozinhas foram as que mais se apropriaram do sistema modular no início do século XX, diretamente ligado a industrialização do mobiliário moderno, em que os módulos são produzidos independentes, mas quando agrupados, formarão um conjunto.

Moraes (1999) remete a este momento da história das cozinhas moduladas como uma referência tecnológica, em que, à semelhança das cozinhas compactas das locomotivas a vapor e dos depósitos de navios, o conceito de compacidade e modulação foi transferido para o projeto da cozinha residencial, adaptando-se ao uso doméstico.

Franco (2015) defende o uso da expressão "móvel componível" como mais adequado para se referir aos produtos do segmento e aponta determinadas ressalvas quanto ao uso da expressão "móvel planejado" e "modulado", muito comum para designar tais produtos. Segundo o autor, "por princípio, "planejado" pode ser todo e qualquer móvel que passou por um processo projetual, vindo a idéia antes da matéria". Da mesma forma, complementa tais definições destacando que o termo "modulado" também foi incorporado inadequadamente, destacando duas razões principais: primeiro é que no sentido lato "módulo" significa "medida de 10 centímetros". A outra razão é que na coordenação modular - definida na apostila de Coordenação Modular, da Escola de Arquitetura da UFMG (apud FRANCO, 2015, p.14) o importante é a repetição da medida e não do elemento, situação contrária ao que acontece nos sistemas de produtos neste segmento, em que a variação está na medida e não na tipologia do produto. Franco também identifica duas vertentes quanto aos sistemas componíveis no mobiliário popular para cozinhas: cozinhas compactas, composta por poucos itens, com a composição dos armários dispostos em uma única parede e cozinhas moduladas, "impropriamente denominadas como tal", segundo o autor, formadas por uma variedade maior de itens, o que possibilita a quase totalidade de arranjos desejados. Esta segunda vertente mais próxima dos produtos investigados aqui neste trabalho, uma vez que a destacada variedade de itens resulta em projetos mais elaborados e personalizados. 
Figura 13 - Divulgação da marca Securit sobre alguns critérios para "cozinhas planificadas" (1955)
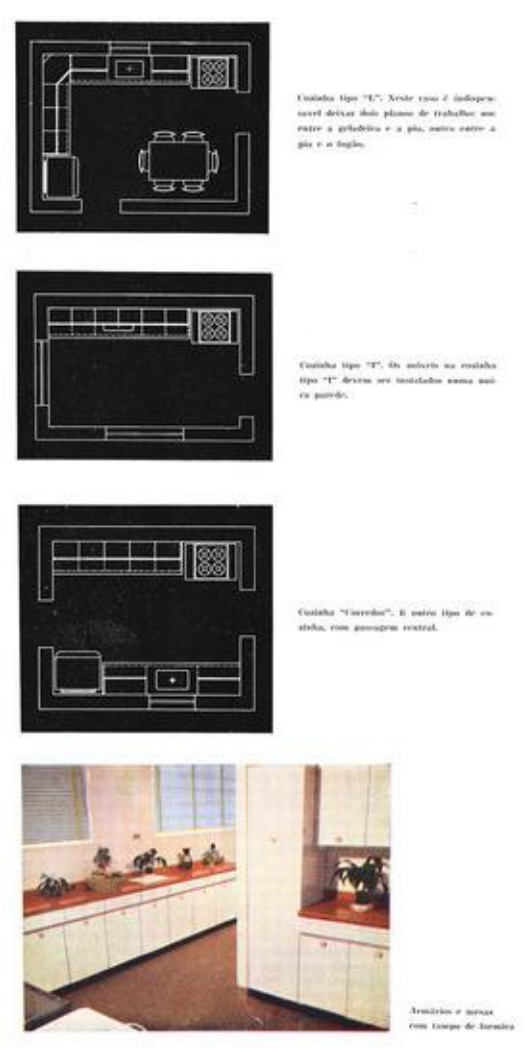
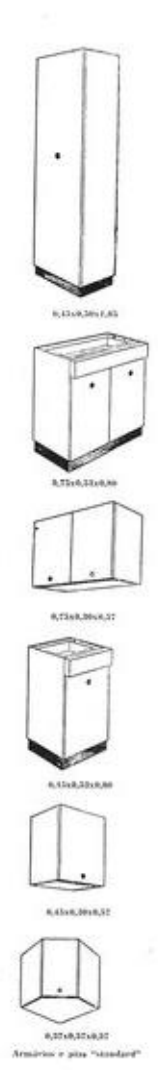
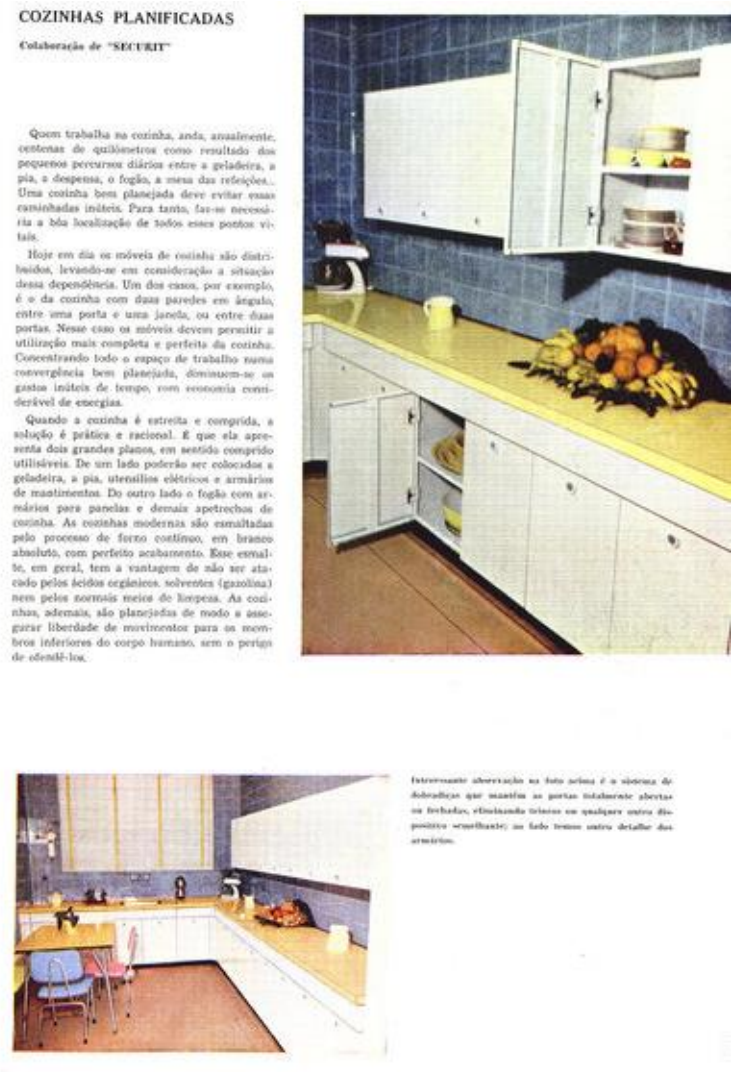

Fonte: http://www.acropole.fau.usp.br/edicao/198/67. Acesso em: 07 jan. 2017.

De fato, no segmento de móveis componíveis para cozinha, os módulos enquanto unidades tridimensionais possuem variações diferentes de 10 centímetros e que nem sempre resultam em medidas múltiplas, entretanto, eles seguem uma lógica construtiva de proporção métrica, o que possibilita múltiplos arranjos quando os módulos são combinados entre si, resultando na composição do projeto da cozinha.

Outra característica dos móveis neste segmento é a prestação de serviço especializado de projeto, estratégia comercial encontrada pelas indústrias produtoras dos móveis no final do século XX como diferencial competitivo de mercado, situação que se perpetua até os dias atuais. Inclusive este serviço especializado de projeto, que até algumas décadas era privilégio das marcas de alto padrão, tem se expandido para outras categorias de consumidores, como as classes $\mathrm{B}$ e $\mathrm{C}$, tendo como principal referência as redes de varejo Tok\&Stok e a Casas Bahia, esta última com a implantação do serviço desde o final do ano de 2015 (ESTADÃO, 2014). 
Figura 14 - Cartaz divulgação da marca Florense sobre o serviço especializado de projeto (1984)

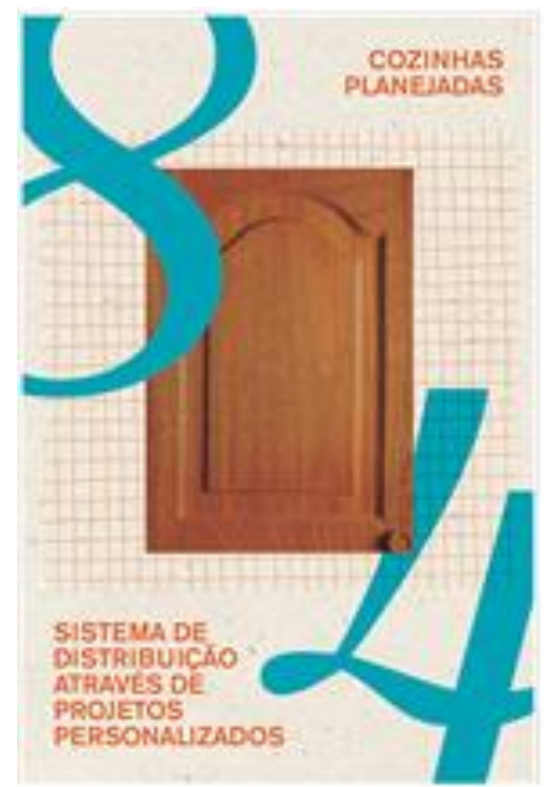

Fonte: http://www.florense.com.br/pt/aflorense. Acesso em: 25 out. 2016.

Este serviço especializado de projeto, como se denomina, é desenvolvido nas lojas e revendas pelas equipes de vendedores projetistas em que, por meio de uma ação projetual, é feito o planejamento e arranjo dos produtos pronto no espaço. Talvez esta seja uma possível constatação para a popularização da expressão "móvel planejado", uma vez que se baseia na arquitetura para a disposição dos módulos no ambiente e, ainda que se trate de produtos padronizados, a variação de acabamentos e dimensões resultará em ambientes personalizados para os clientes.

Também, no catálogo de produtos neste segmento, complementar aos módulos, podem ser identificadas peças tradicionalmente chamadas de tamponamentos, que são painéis soltos de MDF e MDP com largura e profundidade livres, instalados de modo vertical ou horizontal, em espessuras variando entre 12 a $40 \mathrm{~mm}$, e que possibilitam a criação de outros produtos que contribuem para a personalização do projeto: estantes, nichos, prateleiras, tampos para áreas de refeições, embutimento de alguns eletrodomésticos, e são fundamentais para o acabamento lateral dos módulos, de forma que a estrutura não fique aparente. Além dos tamponamentos, encontram-se no catálogo dos fabricantes peças complementares chamadas de arremates, com medidas editáveis e que são instaladas ao final da modulação e que possibilitam a abertura das frentes dos módulos mais que $90^{\circ}$. Da mesma forma, os arremates servem como acabamento, para disfarçar eventuais desníveis nas paredes e no teto, quando os módulos estiverem instalados. 
Figura 15 - Composição de cozinha com tamponamentos de dimensões e acabamentos variados, identificados pelo pontilhado amarelo.

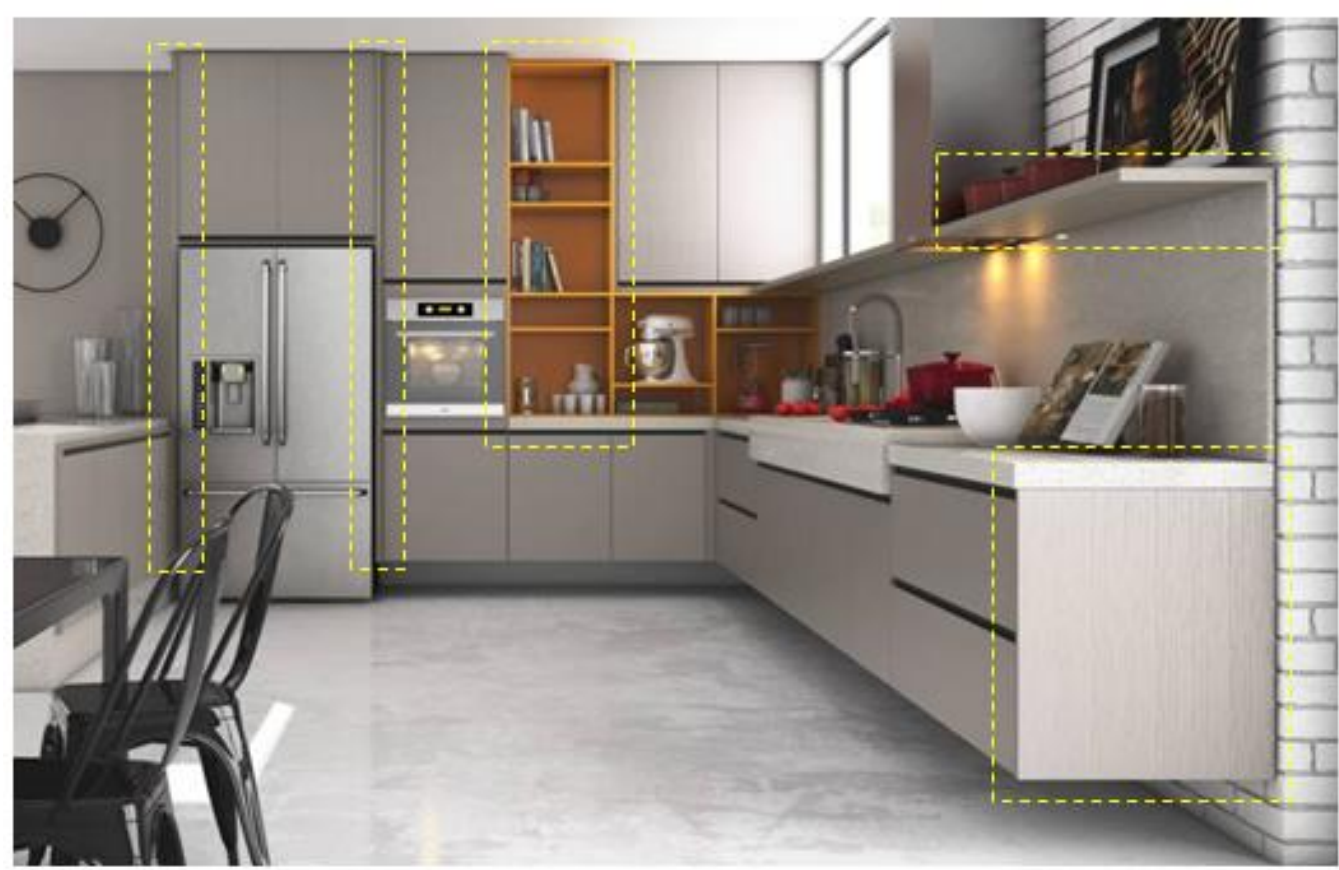

Fonte: http://www.bontempo.com.br/categoria-ambiente/cozinhas/. Acesso em: 07 jan. 2017. Detalhes inseridos pelo autor da Dissertação.

Figura 16 - Composição de cozinha com arremates laterais. Nota-se que por conta dos arremates, os módulos não se encostam à parede.

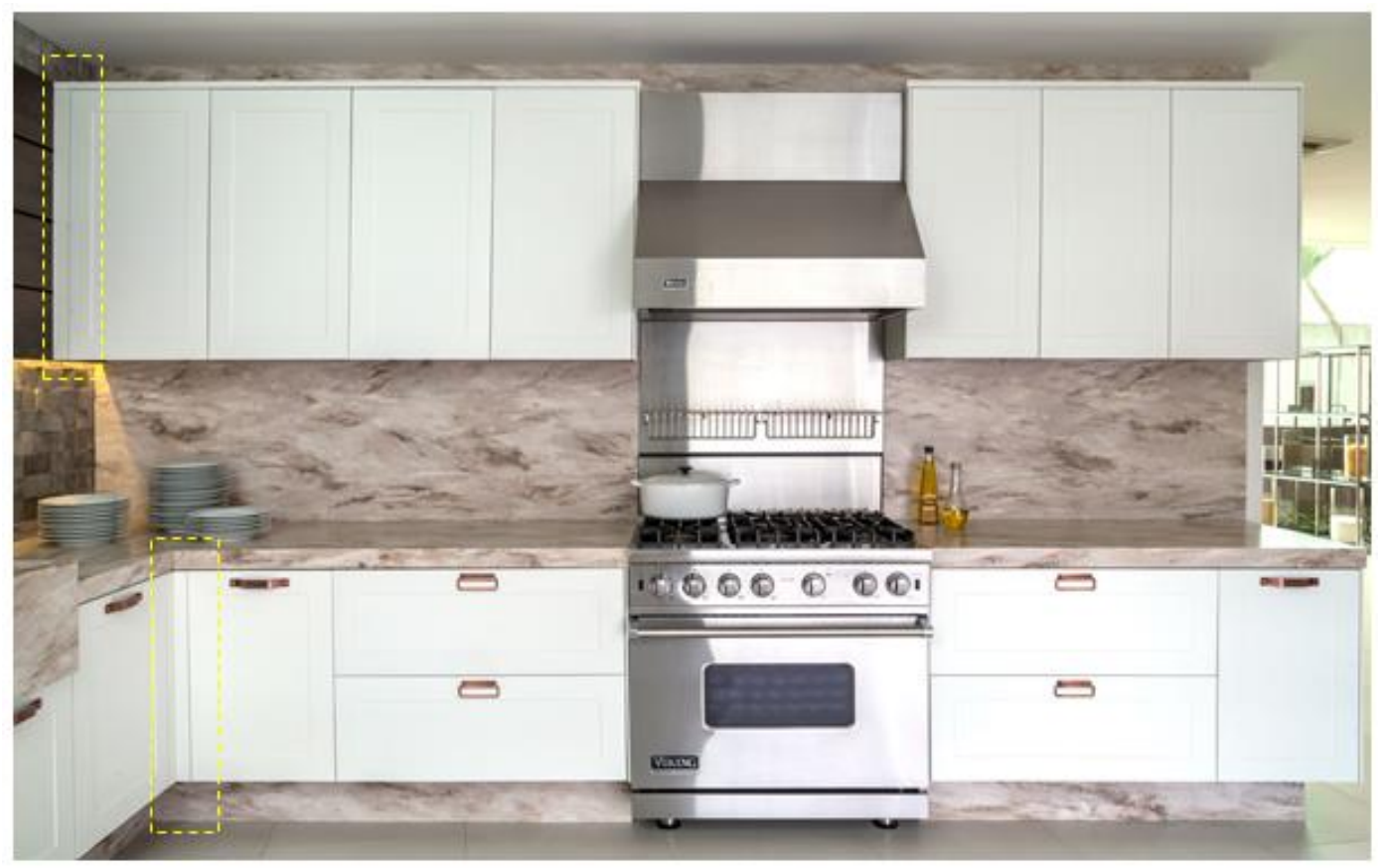

Fonte: http://www.kitchens.com.br/cozinha.php. Acesso em: 07 jan. 2017. Detalhes inseridos pelo autor da Dissertação. 
Figura 17 - Composição de cozinha com arremates superiores. Ainda que bem sútil, nota-se que por conta dos arremates, os módulos não se encostam ao teto.

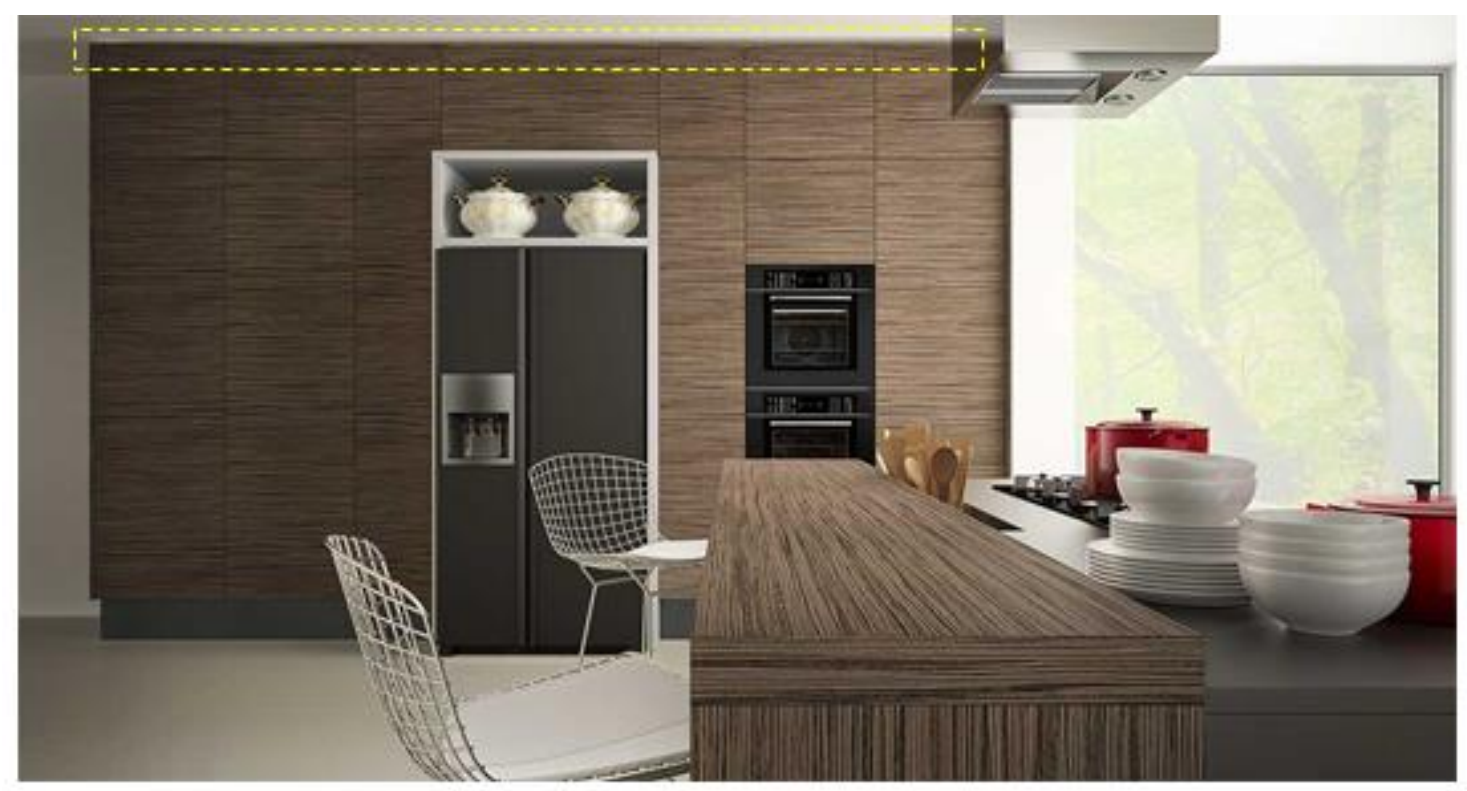

Fonte: http://www.bontempo.com.br/categoria-ambiente/cozinhas/. Acesso em: 07 jan. 2017. Detalhes inseridos pelo autor da Dissertação.

Em todo caso, ainda que erroneamente utilizada, a expressão "móveis planejados" é uma denominação praticamente consolidada não somente entre o público em geral, mas entre algumas indústrias moveleiras, que inclusive a tem utilizado como maneira de identificação de um segmento de produto dentro do mobiliário industrializado. Entretanto, ainda que esta investigação considere o descarte de materiais neste segmento de produtos, diante do que foi exposto, o emprego da expressão "mobiliário modular componível para cozinhas" se mostra mais apropriado. 


\subsection{Características dos produtos}

Nos esquemas abaixo apresentados, é possível perceber que os módulos para uma cozinha são divididos em três tipos básicos: módulos de bancada, módulos aéreos e módulos tipo coluna.

Figura 18 - Esquema modular para projeto de cozinha, da marca Securit

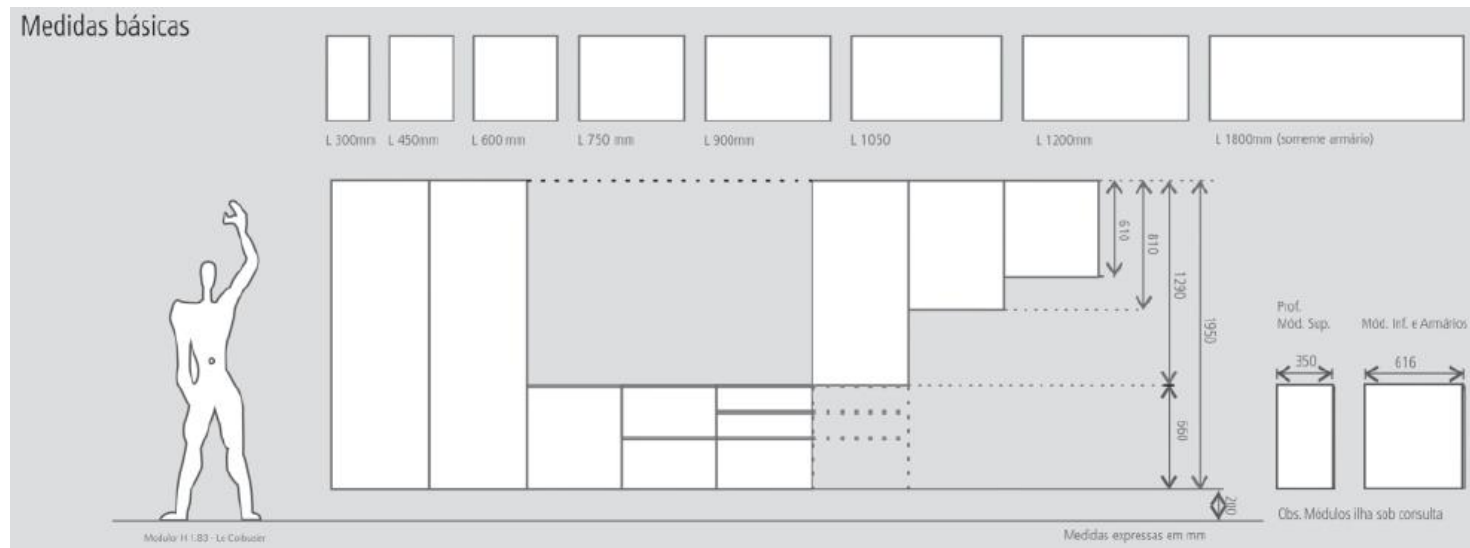

Fonte: http://www.securit.com.br/catalogo/catalogo_50.pdf. Acesso em: 07 jan. 2017.

Figura 19 - Esquema modular de alturas para projeto de cozinha, da marca Leicht

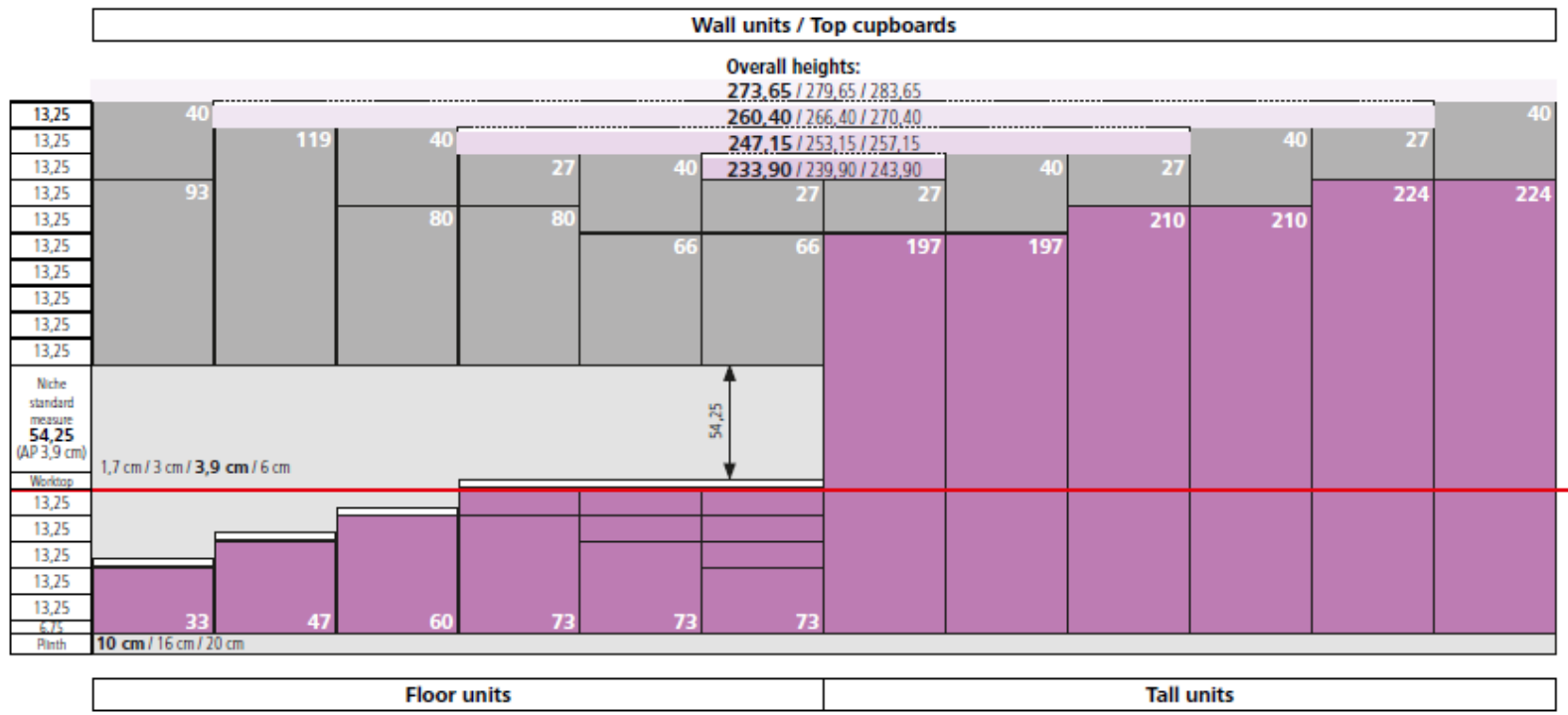

Fonte: Catálogo de produtos Leicht - Price and Type list 2016.

Por conta de certos regionalismos comuns da língua portuguesa, esta nomenclatura naturalmente pode sofrer alterações, como é comum referir-se aos módulos de bancada como gabinetes e aos módulos tipo colunas como despenseiros ou paneleiros, entretanto, qualquer uma destas referências se enquadrarão em um destes três tipos apresentados. 
Entre os materiais empregados na produção e a geometria do produto, os módulos não apresentam distinções, mas para melhor entendimento é necessário separar o que é estrutura do móvel e o que é o produto acabado. Predominantemente de cor clara, como o branco e com revestimento laminado, a estrutura do módulo, também chamada nas fábricas de caixaria, compõe duas laterais, base, fundo e teto, unidos no momento da montagem por meio de cavilhas de madeira (laterais, fundo e teto) e por rotofix metálicos (base e laterais).

Como característica predominante nos produtos deste segmento, foi possível identificar:

- A estrutura do móvel em MDP $15 \mathrm{~mm}$ ou $18 \mathrm{~mm}$, revestidos com laminados de baixa pressão (BP);

- Portas e frentes de gaveta em MDF ou MDP $15 \mathrm{~mm}$ ou $18 \mathrm{~mm}$, revestidos em laminados (AP e BP, conforme a indústria), ou pintura (MDF);

Figura 20 - Estrutura padrão de um módulo de bancada (esquerda) e do módulo instalado (direita)
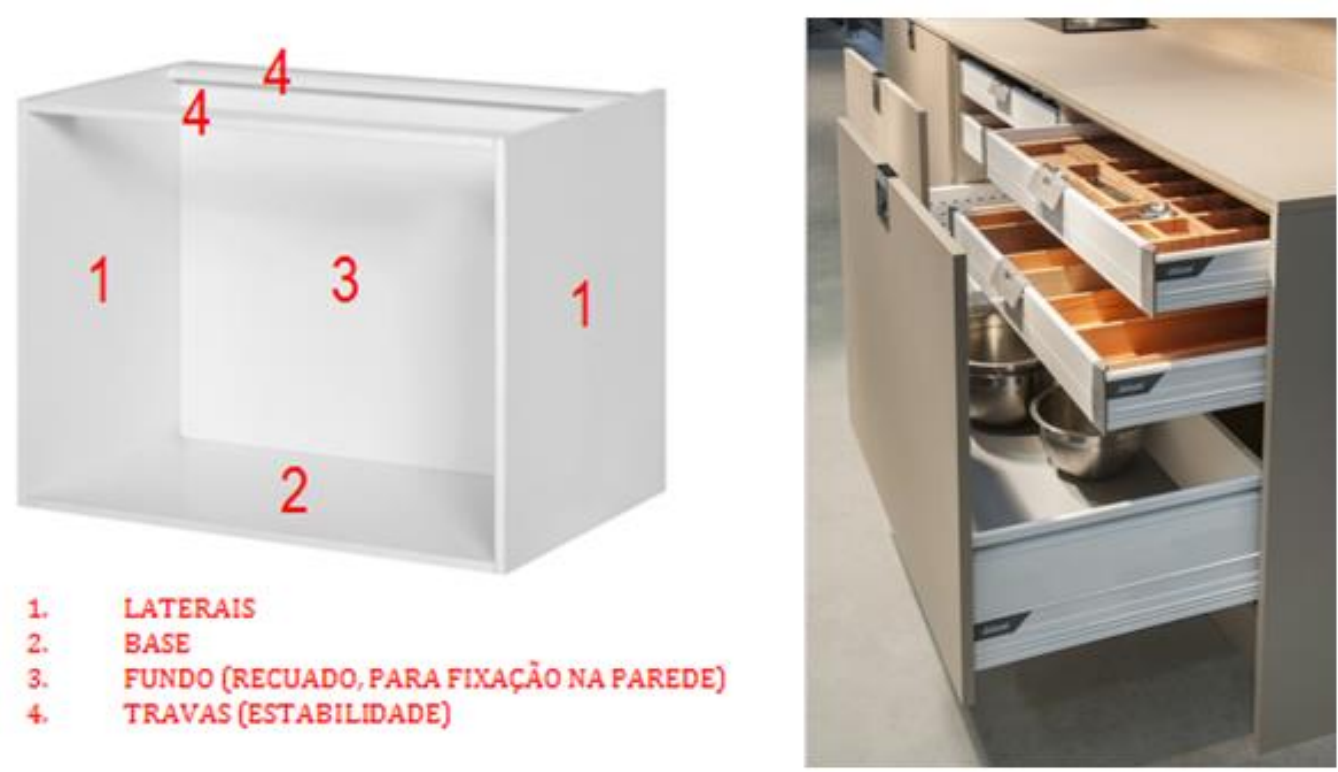

Fonte: http://www.dellanno.com.br/tipo_ambiente/cozinha/. Acesso em 28 dez.2015. Foto do módulo: arquivo do autor. Adaptado pelo autor da Dissertação.

O fundo do módulo, recuado em relação às laterais, embute o par de ferragens para fixação dos módulos na parede, especialmente no caso dos módulos aéreos. Também quanto à fixação, no caso dos módulos inferiores e despenseiros, estes podem ficar ora suspensos do piso, ora apoiados sobre pés plásticos ou metálicos ou ainda apoiados sobre bases de alvenaria, recurso de projeto muito comum, pelo hábito que muitas residências ainda possuem de lavar o piso da cozinha. 
Figura 21 - Parte traseira de um módulo superior para cozinha com o detalhe da ferragem de fixação na parede

Fonte: arquivo do autor.

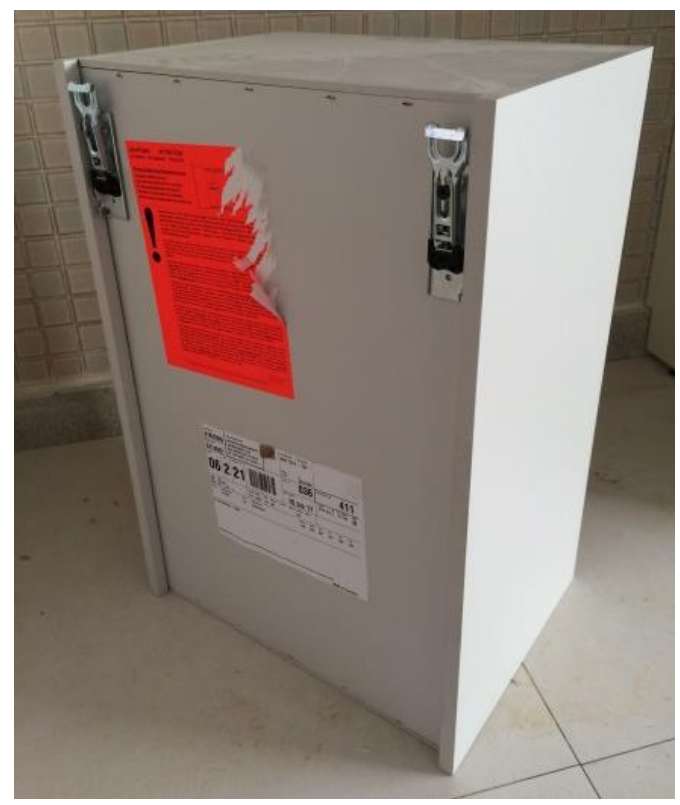

Qualquer que seja a situação, o vão entre o piso e o módulo oscila entre $100 \mathrm{~mm}$ a $250 \mathrm{~mm}$, altura que varia conforme a altura do módulo inferior, definida no catálogo da indústria de cada fabricante, mas respeitando-se o padrão consolidado de ergonomia para a bancada de trabalho, em 900 mm, como medida final para o tampo (PANERO e ZELNIK, 2011).

Ainda quanto à estrutura, há uma exceção aos armários de bancada, que não possuem teto, substituído por travessas longitudinais - ou travas, a fim de garantir a estabilidade do módulo quando montado. A ausência do teto justifica-se pelo fato de que, em se tratando de um armário baixo, este produto receberá um tampo, que formará uma bancada. Outra vantagem da ausência do teto nos módulos inferiores é facilitar as conexões hidráulicas na área da pia, elétricas e de gás na área da lava louças e do fogão, por exemplo, o que evita recorte nos módulos durante e após a montagem. Eventualmente é possível encontrar em alguns fabricantes de módulos para cozinhas estas travessas metálicas em alumínio. De qualquer forma, a estrutura do móvel não é visível quando a cozinha está finalizada, pois assim como os tampos das bancadas, as frentes dos módulos, sejam portas ou gavetas, finalizam a composição. 
Figura 22 - Composição de cozinha da marca Ornare

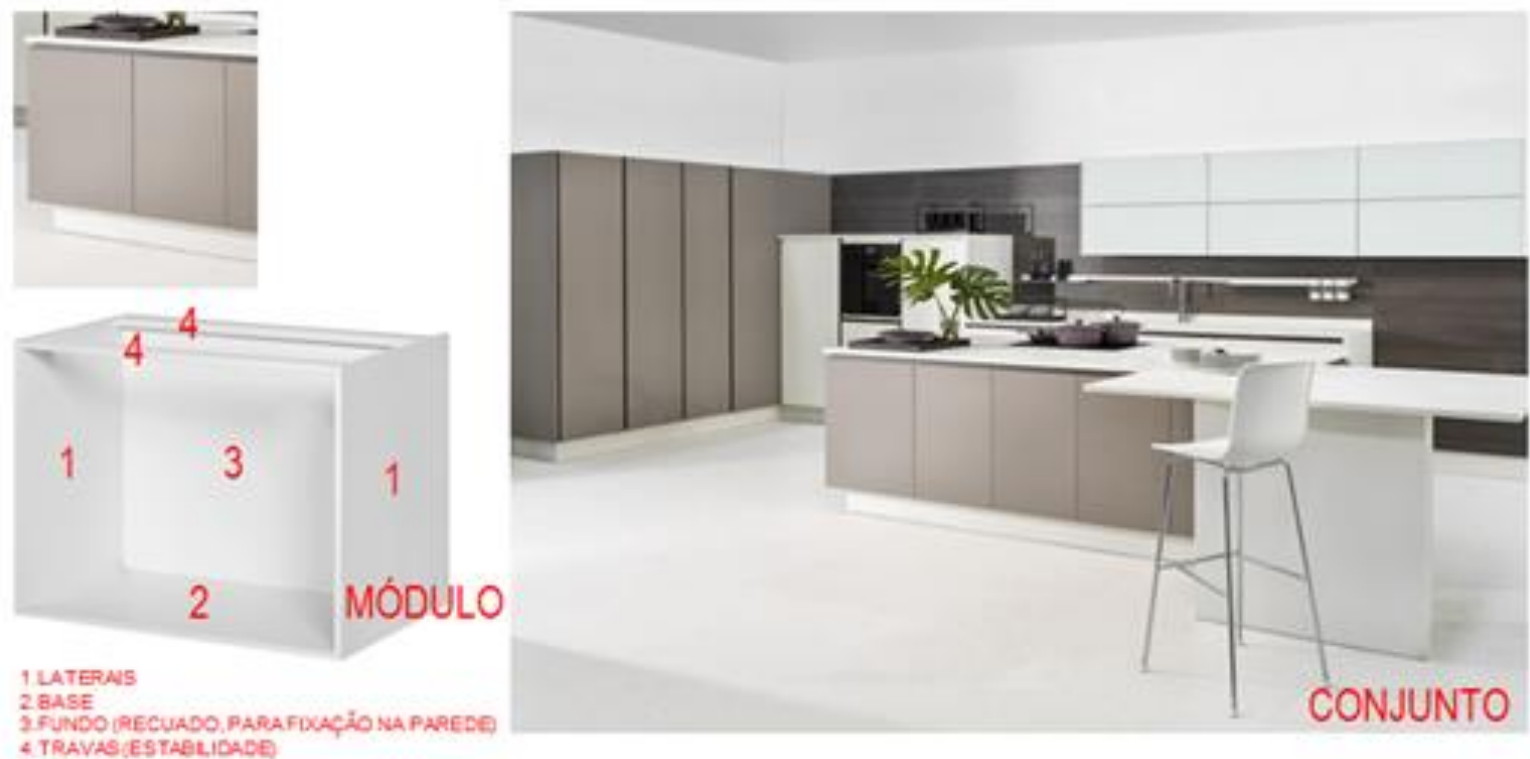

Fonte: http://www.ornare.com.br/cozinhas. Acesso em 28 dez. 2015. Adaptado pelo autor da Dissertação.

Quanto às dimensões de profundidade, os módulos acompanham medidas padrões dos eletrodomésticos de bancada, como fogão e lava louças, sendo assim, com profundidade que varia entre $580 \mathrm{~mm}$ a $650 \mathrm{~mm}$, enquanto os módulos superiores, por questões ergonômicas, ficam recuados da bancada, com profundidade variando em $350 \mathrm{~mm}$. Quanto à largura dos módulos, como característica geral, é possível encontrar medidas a partir de $100 \mathrm{~mm}$, chegando até $1200 \mathrm{~mm}$ para um mesmo módulo, e naturalmente com variações de acordo com o catálogo de cada fabricante. Na figura 18 percebe-se uma modulação mais enxuta, com larguras a cada 150 mm e nos módulos indicados na figura 19, a variação encontrada foi a cada $50 \mathrm{~mm}$.

Na composição geral dos módulos, como resultado do produto pronto é possível identificar três principais variáveis, que têm relação direta com as suas medidas e com a oferta de produtos dos fabricantes fornecedores de insumos para as indústrias moveleiras:

- Configuração interna, tais como gavetas, prateleiras fixas ou aramadas, acessórios e ferragens;

- Puxadores e mecanismos de abertura das portas e frentes de gavetas, tais como dobradiças, corrediças, pistões a gás, sensores automáticos, entre outros.

- Revestimentos da superfície das portas e frentes de gavetas, tais como laminados, pintura, vidro fosco ou brilhante. 
Figura 23 - Estrutura de um módulo em MDP (direita) e do mesmo módulo instalado com as frentes em MDF pintado (esquerda)

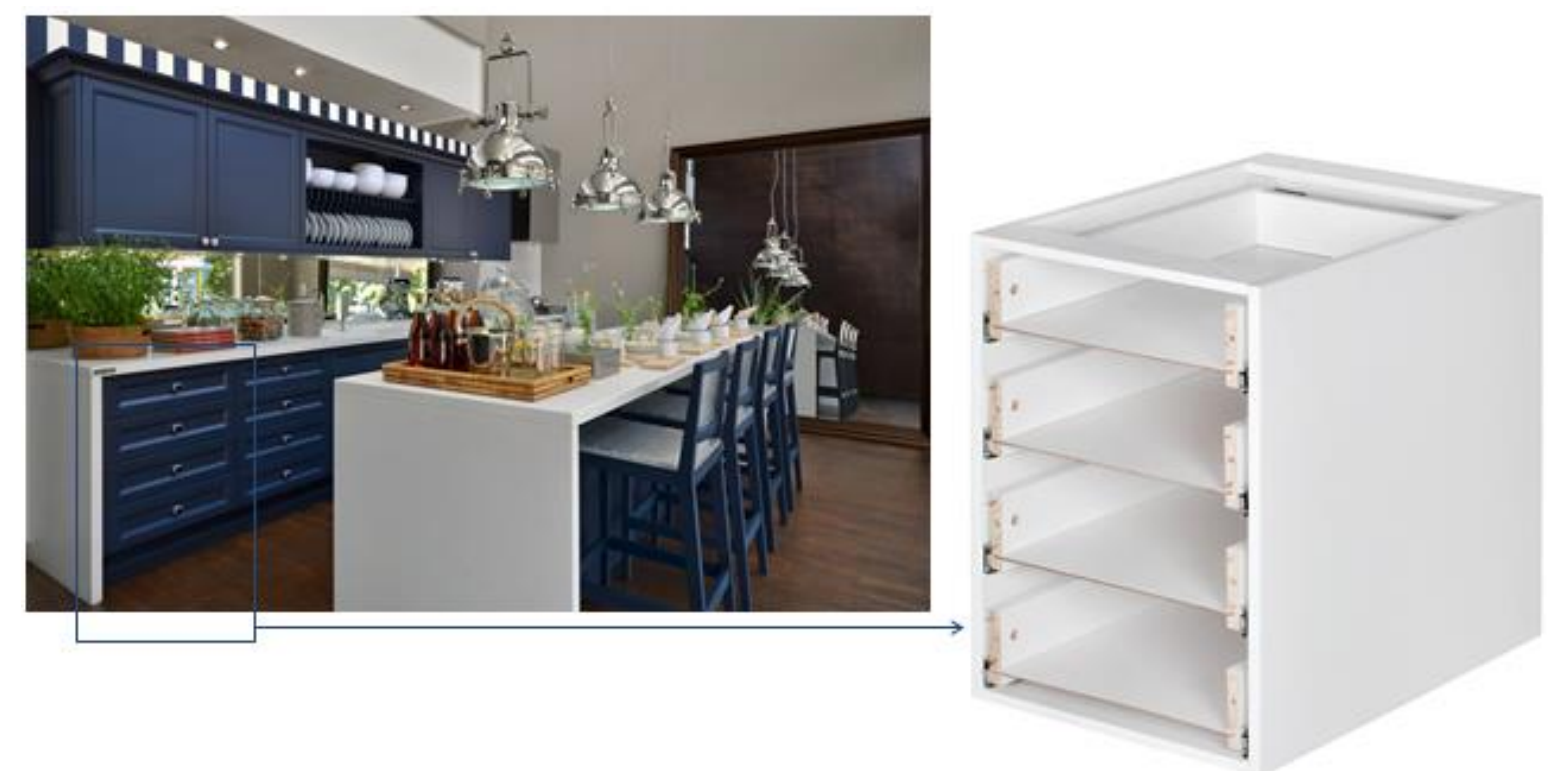

Fonte: http://www.florense.com.br/pt/produtos/cozinhas/charm-bistrot/13154/\#!gallery/12/. Acesso em 28 dez. 2015. Elaborado pelo autor.

Um exemplo desta relação direta dos módulos com seus componentes podem ser consideradas as ferragens para armários basculantes, que até a poucos anos possuíam restrição de largura máxima para módulos de 60 a $90 \mathrm{~cm}$ - atualmente é possível encontrar estas ferragens para módulos com portas únicas de até 1,8m de largura, como as desenvolvidas para o sistema Aventos, da marca austríaca Blum. Ainda na relação direta módulo-componentes, os revestimentos laminados estampados, principalmente nos padrões madeirados, os veios da estampa da madeira não serão contínuos em um projeto em que a composição modular ultrapasse a medida máxima do painel de 1840×2750.

Sendo assim, estas e outras características técnicas dos componentes impactam diretamente no resultado do projeto da cozinha e exigirão por parte dos projetistas o máximo de atenção durante as etapas de desenvolvimento do produto e do projeto.

Da mesma forma, é possível perceber que o projeto de cozinha é uma rede que engloba um grupo de etapas (venda, projeto, indústria e montagem) e outros fornecedores, como os de eletrodomésticos, cubas, tampos das bancadas e responsabilidades do escopo da arquitetura, como piso, revestimentos, e instalações elétricas, hidráulica e de gás. Conclui-se que o projeto de cozinha envolve uma combinação de elementos que para garantir um bom resultado, precisam estar bem coordenados entre si. 
3. Método 
Este capítulo apresenta os procedimentos metodológicos utilizados na pesquisa e descreve a abordagem de pesquisa utilizada, o objeto de estudo, as fontes de dados, as técnicas utilizadas para coleta de dados e as técnicas utilizadas no seu tratamento. Finaliza-se com uma síntese da estrutura metodológica por meio de um quadro sinóptico.

\subsection{Caracterização geral da pesquisa}

Esta pesquisa procurou investigar e descobrir os aspectos mais representativos sobre o descarte de materiais, em especial o descarte de madeira reconstituída (tais como o MDF e o MDP) no segmento de móveis modulados componíveis para cozinhas, tendo como principal fonte de dados especialistas e profissionais do setor, com o objetivo de traçar um panorama qualitativo sobre o tema: as circunstâncias geradoras de descarte de materiais, tipos de material descartado e destinação.

Tais atributos, segundo Creswell (2014), concedem à investigação uma abordagem qualitativa, pois permite uma visão geral do processo, alcance que não seria possível em estudos baseados puramente em estatísticas ou que não considerassem os aspectos subjetivos dos indivíduos participantes do estudo, por exemplo. Trata-se, assim, de um estudo em que se procurou explorar o tema a fim de obter uma compreensão mais detalhada sobre o assunto.

Da mesma forma, baseada nestes objetivos trata-se de uma pesquisa de natureza exploratória que, segundo Gil (2002, p.41) "permite maior familiaridade com o tema, com vistas a torná-lo mais explícito". Ainda, para este autor, este tipo de pesquisa possui um planejamento mais flexível, para permitir considerações dos mais variados aspectos do problema pesquisado e, na maioria dos casos, assume a forma de estudo de casos, modalidade que se mostrou a mais adequada para coleta de dados neste trabalho, uma vez que permite a investigação em profundidade dos fenômenos dentro do seu contexto real (YIN, 2010) e, no estudo de múltiplos casos utilizado neste trabalho, serve para mostrar diferentes perspectivas para a mesma questão (CRESWELL, 2014). 


\subsection{Coleta de dados}

Quanto ao desenvolvimento da pesquisa e as técnicas utilizadas para a coleta de dados, foram considerados os quatro procedimentos básicos recomendados por Creswell (2007) visando garantir a maior assertividade dos dados: pesquisa bibliográfica (apresentados no capítulo 1 e 2 desta Dissertação), entrevistas, observação em campo e registro áudio visual. Desta forma, a investigação foi organizada e conduzida de modo a contemplar tais procedimentos de acordo com os subproblemas e os objetivos gerais e especificados definidos no início da investigação.

Como estratégia defendida por Flick (2004) para coleta de dados em pesquisa qualitativa, o modelo de entrevista semiestruturada possibilita ao pesquisador, a partir de um roteiro flexível de perguntas abertas, escolher a sequência de perguntas conforme os inputs que o entrevistado fornece. Tal roteiro se tornou uma estratégia assertiva nos estudos de casos múltiplos utilizados neste trabalho, respeitando-se a diferença de perfil dos entrevistados em todas as etapas do processo e que permitiu o cruzamento de dados entre as respostas fornecidas.

Outra fonte de coleta de dados foi realizada por meio de atuação em campo, com observação não participante dentro das indústrias e durante a etapa de montagem das cozinhas. Nas indústrias foi possível acompanhar toda a etapa de produção, da seleção do material até as etapas de embalagem e expedição. Na montagem, esta técnica abriu novos caminhos para a investigação, em que foi possível perceber a figura do analista de assistência técnica, profissional responsável pelos problemas com o produto montado, identificando peças danificadas que precisam ser substituídas, aspecto diretamente relacionado ao tema desta investigação. Da mesma forma, a partir destas observações nas indústrias e nas montagens, foi possível traçar um cenário geral do processo e cruzar as informações entre o que foi dito nas entrevistas e o que foi percebido em campo. 


\subsection{Participantes e Protocolos}

A seleção dos participantes foi dividida em três grandes grupos, de acordo com as etapas do processo consideradas como as mais representativas quanto ao objeto do estudo:

Figura 24 - Fontes de dados primários considerados na investigação

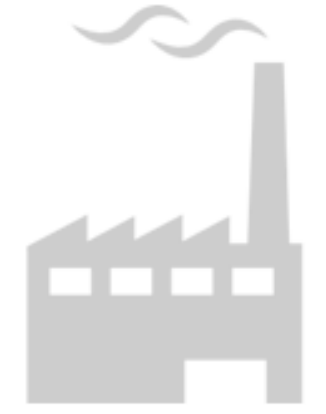

PRODUÇÃO INDUSTRIAL

Empresários

Diretores industriais

Setores da produção

Designers de produto

Visitas às fábricas

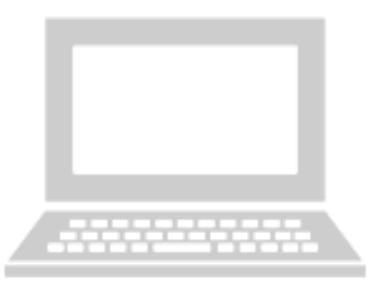

PROJETO

Projetistas técnicos

Coordenadores de projeto

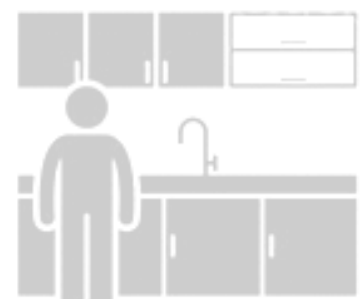

\section{MONTAGEM}

Montadores de móveis Analistas de pós venda

Acompanhamento de montagem

Fonte: Montagem da ilustração elaborado pelo autor da Dissertação.

Quanto aos protocolos utilizados, foram considerados os profissionais envolvidos com a atividade de produção industrial, projeto e montagem de móveis componíveis para cozinha com pelo menos cinco anos de atividade, de diferentes empresas, para que fosse possível a obtenção de um maior alcance de resultados e dados mais confiáveis em relação ao domínio em uma atividade. Outra característica quanto aos protocolos é que o material predominante para fabricação dos módulos fosse a madeira reconstituída, em suas variações o MDF e o MDP.

As entrevistas realizadas com os profissionais e as observações em campo nas indústrias e nas etapas de montagem foram realizadas entre os dias 20 de abril de 2015 ao dia 28 de dezembro de 2016. A relação das indústrias visitadas e dos profissionais entrevistados bem como a documentação utilizada durante a coleta de dados em campo encontra-se no Apêndice desta Dissertação. 


\subsection{Procedimentos metodológicos na etapa de produção industrial}

A consulta a fontes de dados primários incluiu, nesta etapa, entrevistas com profissionais e setores envolvidos na produção, por meio de entrevistas semiestruturadas realizadas pessoalmente, gravadas e eventualmente anotadas, com a finalidade de coletar dados relacionados aos objetivos específicos:

- Apresentar as principais circunstâncias responsáveis pela ocorrência de descarte de materiais;

- Levantar os tipos de material descartado;

- Verificar como é feito a destinação do descarte deste material;

Quanto às observações em campo nas indústrias, foram feitas gravações em áudio e quando autorizado, foi realizado o registro fotográfico.

\subsection{Procedimentos metodológicos para coleta de dados na etapa de projeto}

A consulta a fontes de dados primários incluiu, nesta etapa, entrevistas semiestruturadas realizadas pessoalmente, com o material gravado, com a finalidade de coletar dados relacionados aos objetivos específicos:

- Apresentar as principais circunstâncias responsáveis pela ocorrência de descarte de materiais;

Nesta etapa, os projetistas foram estimulados a trazer e a representar exemplos práticos na atividade de projeto que pudessem estar relacionados ao tema da investigação.

\subsection{Procedimentos metodológicos para coleta de dados na etapa de montagem}

Nesta etapa, a consulta a fontes de dados primários incluiu entrevistas semiestruturadas, realizadas pessoalmente, com as respostas anotadas, com profissionais e setores envolvidos na montagem e assistência técnica. Quanto às observações em campo, foram acompanhadas ao total vinte e duas montagens de cozinha, na região metropolitana de São Paulo. 
Durante a observação destas montagens foram feitas anotações do pesquisador por meio de ficha de observação e registro fotográfico, com a finalidade de coletar dados relacionados aos objetivos específicos:

- Apresentar as principais circunstâncias responsáveis pela ocorrência de descarte de materiais;

- Levantar os tipos de material descartado;

- Verificar como é feito a destinação do descarte deste material;

Outra técnica utilizada nesta etapa foi a análise da documentação de montagem, contendo a lista de peças do que foi produzido na indústria e o projeto executivo elaborado pelo projetista. Por esta razão, a coleta de dados foi dividida em dois momentos: em um primeiro momento, no segundo semestre de 2015 foram realizadas as primeiras observações, que possibilitaram novas abordagens para as entrevistas com os projetistas. Paralelamente com as entrevistas com os projetistas, uma nova coleta de dados com os montadores foi realizada no segundo semestre de 2016: segundo momento. 
Figura 25 - Quadro sinóptico com a estrutura metodológica da dissertação

Título

Problema

Fundamental

Subproblemas

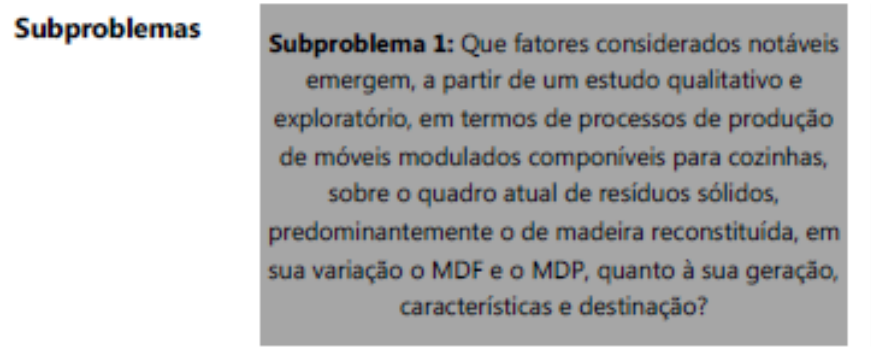

dados $A$

Principais circunstâncias responsáveis pela ocorrência de descarte de materiais, Tipos de materiais descartados, Destinaçăo do material descartado.

\section{fontes}

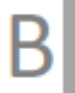

Empresários, diretores industriais, engenheiros,

técnicos de produção; designers de produto: Visita técnica às fábricas

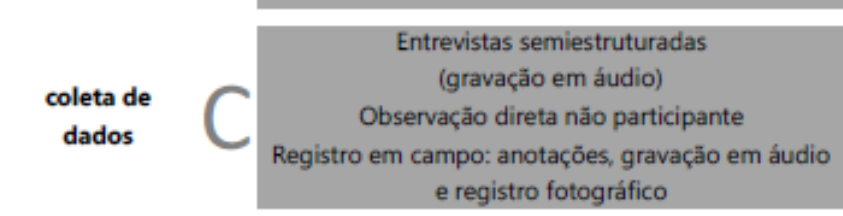

tratamento de

dados

Transcrição do material, classificação e identificação de padrōes recorrentes

PANORAMA DO DESCARTE DE MATERIAIS NAS ETAPAS DE PRODUÇĀO INDUSTRIAL, PROJETO E MONTAGEM reconstituida, em sua variação o MDF e o MDP, quanto à sua geração, características e destinação?

MOBILÁRIO MODULAR COMPONIVEL PARA COZINHAS:

Que fatores considerados notáveis emergem, a partir de um estudo qualitativo e exploratório, em termos de processos de produçăo, atividade de

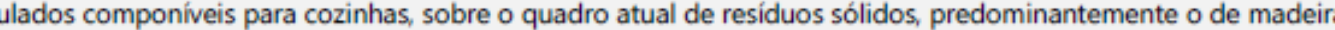
$\underset{\text { indagações }}{\text { exploratórias }} \mathrm{E}$

A sustentabilidade ou os aspectos ecológicos de um produto não abordados no desenvolvimento do projeto (incluindo suas múltiplas fases), quais as consequências mais notáveis podem ser identificadas em relação ao descarte de materiais? Quais circunstâncias no sistema-produto podem ser identificadas como as mais propensas ao descarte de materiais? O que é feito com este material que, não sendo utilizando, se torna resíduo sólido?

Fonte: Quadro sinóptico elaborado pelo autor da Dissertação. 
4. Resultados e Discussão 
Com o propósito de contribuir para a visão sistema-produto no segmento de cozinhas moduladas componíveis e facilitar a construção do panorama qualitativo de descarte de materiais, objetivo central desta pesquisa, este capítulo foi organizado em quatro subcapítulos. O primeiro subcapítulo apresenta uma visão global do processo do produto, em que se tentou, na medida do possível, dividi-lo por etapas e seguir uma ordem cronológica demonstrando a maneira como as ações ocorrem. Os demais subcapítulos apresentam os resultados dos dados tratados referentes ao descarte de materiais, que foram organizados por meio dos padrões recorrentes identificados na análise dos dados e que pretendem discutir o tema da pesquisa de acordo com os três grupos de fontes de dados selecionados como os mais representativos para esta investigação: produção industrial, projeto e montagem.

\subsection{Móveis modulados componíveis: do projeto do produto à montagem}

De maneira circunstanciada para esta investigação, foram identificadas seis principais etapas diretamente relacionadas com o produto modular para o segmento de móveis para cozinhas, tendo o desenvolvimento do produto como ponto de partida para toda a operação:

Figura 26 - Fluxograma do sistema-produto do segmento de móveis componíveis para cozinha

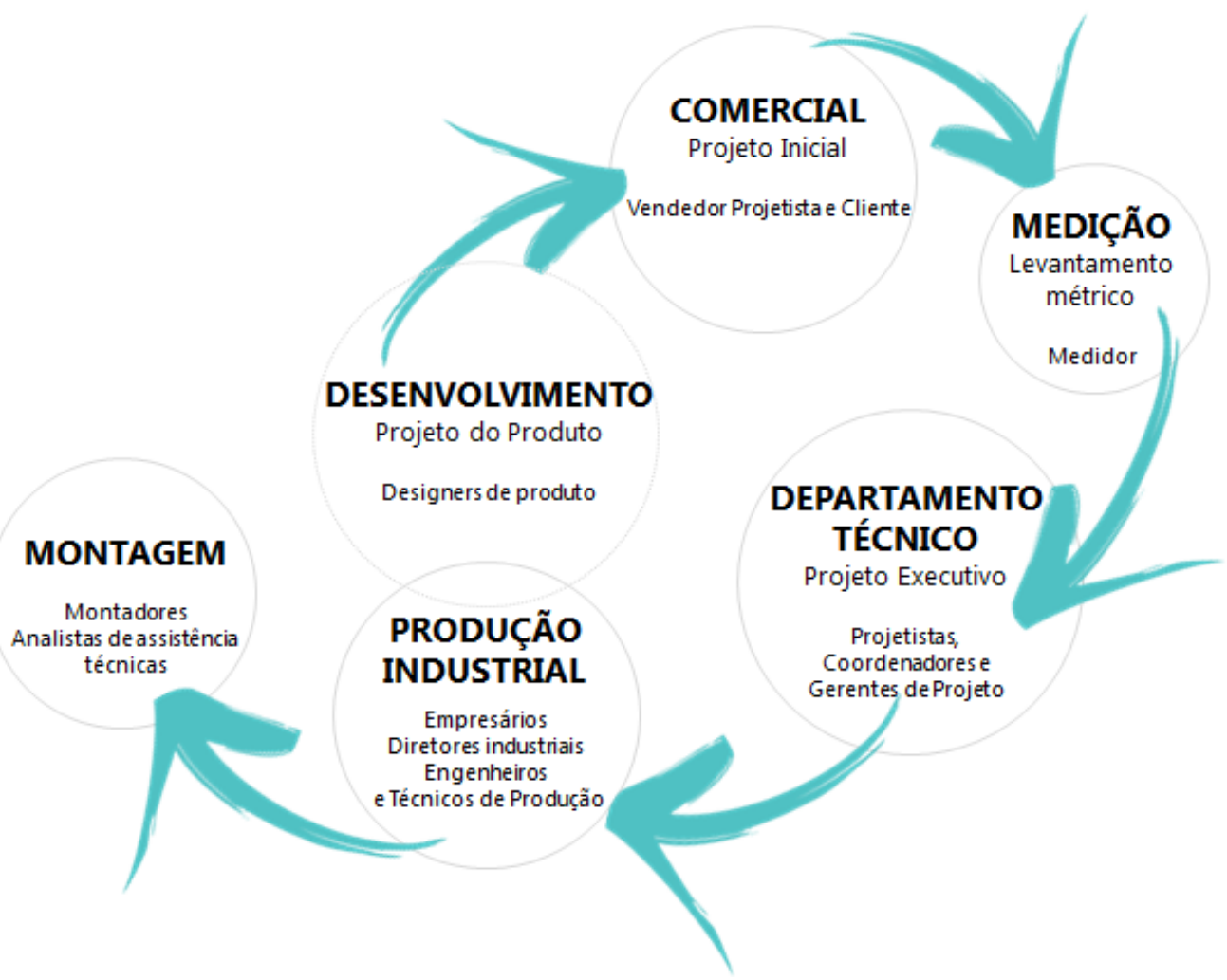

Fonte: Fluxograma elaborado pelo autor da Dissertação. 


\subsubsection{Etapa de desenvolvimento do produto}

Realizado nas indústrias por equipes de designers, o desenvolvimento de produtos para empresas de móveis modulados representa um grande desafio, pois o módulo de cozinha é um produto que já está pronto, com a sua geometria definida. Da mesma forma, se considerado os materiais empregados em sua produção, os fornecedores de insumos são praticamente os mesmos, tendo como os mais conhecidos: Duratex, Masisa, para os painéis de madeira reconstituída; Fórmica, Madepar, para os laminados de alta pressão; Blum, Häfele, para os acessórios e componentes, sem contar os fornecedores das máquinas industriais, em geral importadas dos mesmos fabricantes europeus, por exemplo. Em todo caso, o desenvolvimento do produto é uma etapa fundamental no processo, por conta principalmente do número representativo de indústrias no setor, e que deve exigir da equipe de design algumas estratégias no produto para a sua diferenciação frente à concorrência.

Eduardo Bellizia (2015) e Ane Dallago (2015), ambos gerentes de desenvolvimento de produto de diferentes empresas de móveis modulados, apontam pelo menos três critérios para o processo criativo, que começa pela análise de mercado dentro e fora do Brasil, com visitas a feiras para verificação do que os fabricantes de equipamentos e matéria prima estão lançando de novidades e como isto pode ser incorporado ao catálogo de produtos da indústria. Apontam ainda que, em muitos casos, a demanda por lançamento de novos itens parte do departamento comercial, pois entendem que este é o canal direto com os consumidores. Também são feitas visitas ao showroom de empresas concorrentes, para verificar o portfólio de produtos, os acabamentos expostos e os conceitos de projeto utilizados.

Dallago (2015) destaca que cada alteração de produto ou novo produto que é inserido no catálogo uma comissão se reúne para discussão. Estas reuniões são compostas por funcionários de desenvolvimento de produto, compras, marketing e alguns setores da produção, pois qualquer alteração mal sucedida pode se tornar um prejuízo muito grande.

De maneira geral, segundo Bellizia (2015), o lançamento de produtos para o segmento de móveis modulados considera, basicamente, a tecnologia e novidades em ferragens, acessórios e componentes, novos tipos de mecanismos para abertura das portas e gavetas e principalmente o design da superfície, que no caso dos revestimentos laminados é um item que pode ser solicitado sob medida aos fabricantes dos painéis de MDF e MDP (mediante a 
compra de grandes lotes). No caso da superfície pintada, o processo de pintura dentro da indústria pode personalizar o acabamento para o cliente, em variadas opções de cores e texturas. Os dois profissionais citados relataram que dedicam muita atenção quanto à escolha dos revestimentos destas superfícies, principalmente os estampados e madeirados, para que possibilitem fáceis combinações com outros revestimentos e para que o desenho da estampa não fique desproporcional, no caso dos módulos estreitos, por exemplo.

Por fim, outra característica quanto ao desenvolvimento de produtos no segmento de cozinhas moduladas é que, salvo exceções, as indústrias de móveis possuem estruturas essencialmente familiares, e em boa parte das vezes a decisão sobre o lançamento de novos produtos ou a descontinuação de produtos existentes pode partir exclusivamente do dono da empresa.

\subsubsection{Etapa comercial}

$\mathrm{Na}$ etapa comercial, realizada pelo que se denomina varejo especializado, foi possível encontrar ao menos duas modalidades de negócios:

1. Lojas próprias: unidade de negócios vinculada às indústrias produtoras dos móveis, tais como a Kitchens, Ornare, Formaplás, entre outras.

2. Revendas, subdivididas em dois grandes grupos:

- Franquias: unidade de negócios independente; modelo que permite maior autonomia ao proprietário da loja, inclusive, em comercializar outros produtos no mesmo espaço. Como exemplos de franquias, podem-se encontrar as marcas Florense, Bontempo, Todeschini, SCA, entre muitas outras.

- Representação: mais comum para marcas estrangeiras, com investidores brasileiros. Na cidade de São Paulo foi possível identificar no segmento de móveis modulados para cozinhas as marcas alemãs Leicht e Poggenpohl e a italiana Valcucine ${ }^{7}$.

Este varejo especializado conta com uma área de demonstração, em que os produtos são apresentados como os ambientes de uma casa e com os elementos que compõem uma cozinha (área de cuba e eletrodomésticos, por exemplo), de modo que o cliente tenha a oportunidade de abrir portas e gavetas, sentir a textura das superfícies dos materiais e testar ferragens e mecanismos e, como exposto anteriormente, o diferencial destas lojas é o serviço especializado de projeto, realizado por um vendedor projetista.

\footnotetext{
${ }^{7}$ Dados levantados no segundo semestre de 2016 pelo autor da Dissertação.
} 
Nesta área de demonstração em lojas físicas, todo o conceito de apresentação dos produtos e tipos de produtos expostos, cores e acabamentos dos materiais e superfícies, são concebidos na etapa de desenvolvimento de produto, que buscam traduzir nestes espaços os valores da marca. Nota-se também que estes espaços são renovados em média a cada dois anos, tempo de maturação das linhas de produtos para a troca das coleções. Algumas exceções podem ser atribuídas às revendas que, por questões de retorno de investimento podem ficar com o mesmo produto exposto por mais tempo: no caso de troca de coleções ou produtos descontinuados pela indústria, estas revendas realizam pequenos ajustes no projeto da loja, com substituições pontuais, de frentes, ferragens, acabamentos, etc.

Figura 27 - Foto de cozinha em exposição no showroom da marca Ornare

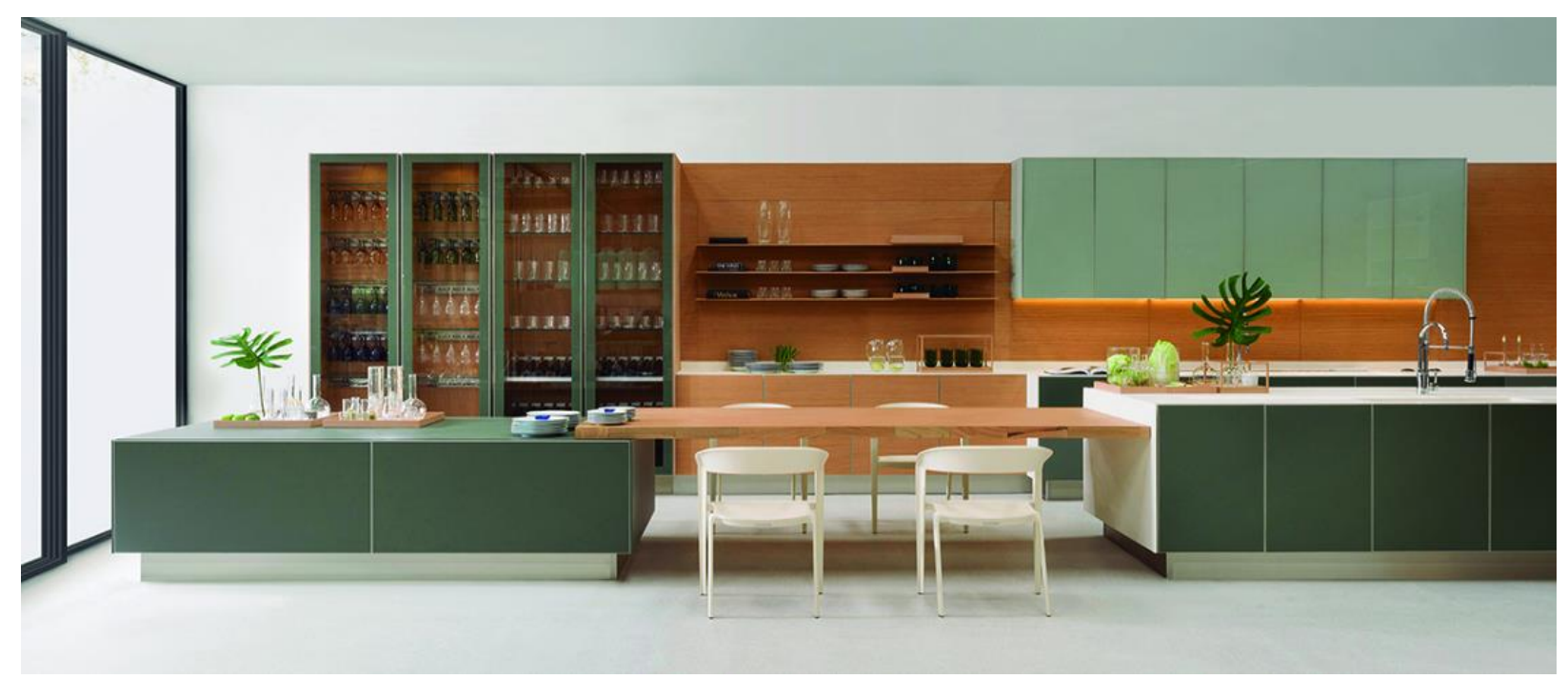

Fonte: http://ornare.com.br/pt/produtos/cozinhas/. Acesso em: 28 dez.2015.

Nestas lojas, a atividade projetual de definição do layout, com a distribuição dos módulos conforme setorização das áreas (preparo, lavagem, armazenagem e cocção) é a primeira etapa do planejamento de uma cozinha. Em geral, em cozinhas pequenas de apartamentos, este layout é pré-definido pelo padrão da construtora. Em outros casos, podem surgir alterações quando os clientes contratam profissionais de arquitetura ou design de interiores ou até mesmo situações em que os clientes procuram diretamente as empresas de cozinhas para auxiliá-lo. Seja qual for a situação, a partir desta distribuição dos módulos no espaço, os vendedores projetistas de cozinhas buscam equalizar as dimensões do espaço disponível com as preferências pessoais dos clientes consumidores, disponibilidade dos produtos da marca e a especificação dos eletrodomésticos. Este projeto, chamado de projeto inicial, é apresentado aos clientes por meio de perspectivas coloridas, realizadas por programas de computador, tais como 2020Design e Promob. 
Figura 28 - Exemplo de layout desenvolvido por profissionais de arquitetura ou de design de interiores
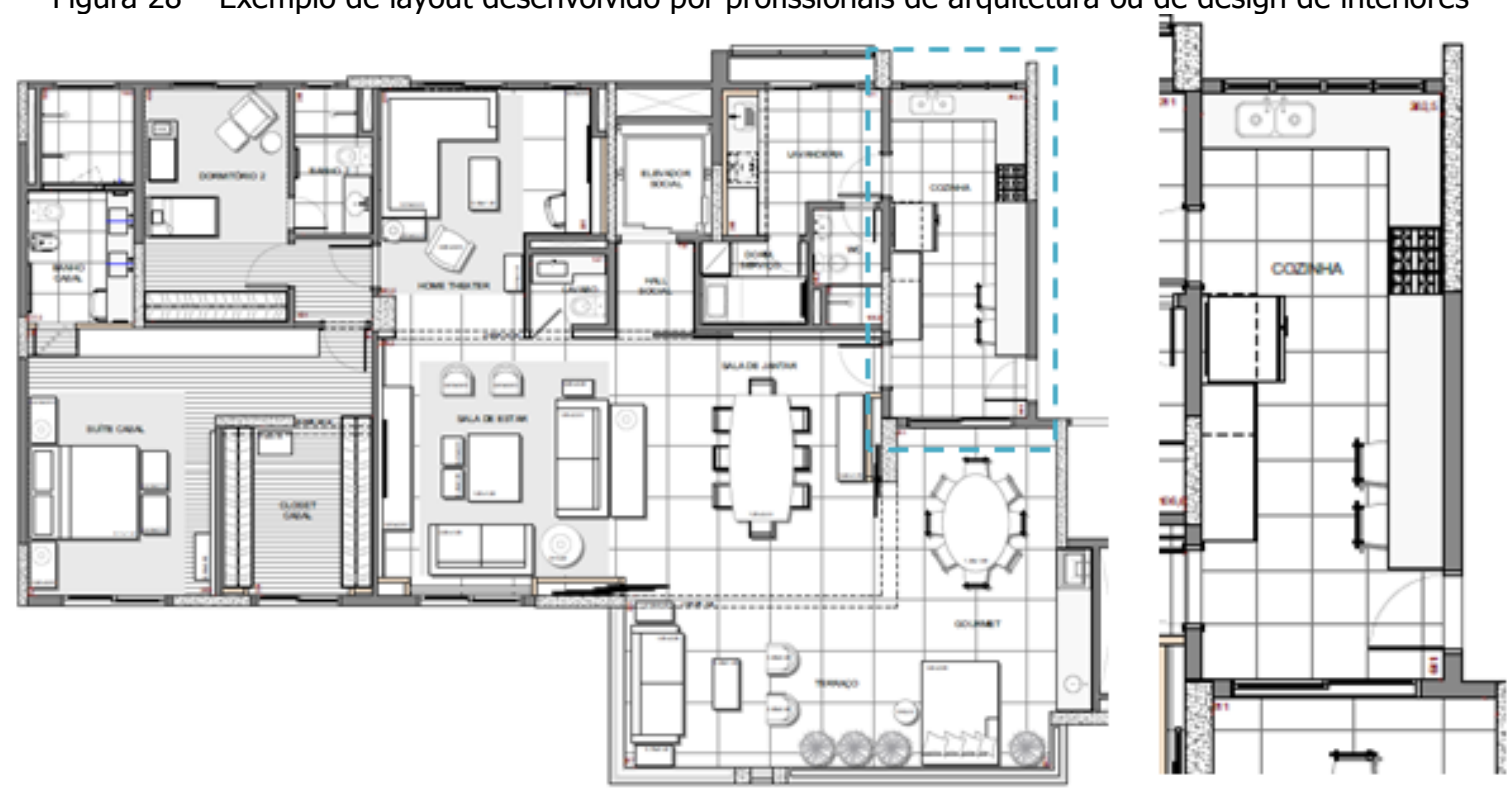

Fonte: Arquivo do autor.

Figura 29 - Exemplo de perspectivas coloridas desenvolvidas por vendedor, baseado na planta do imóvel da figura anterior
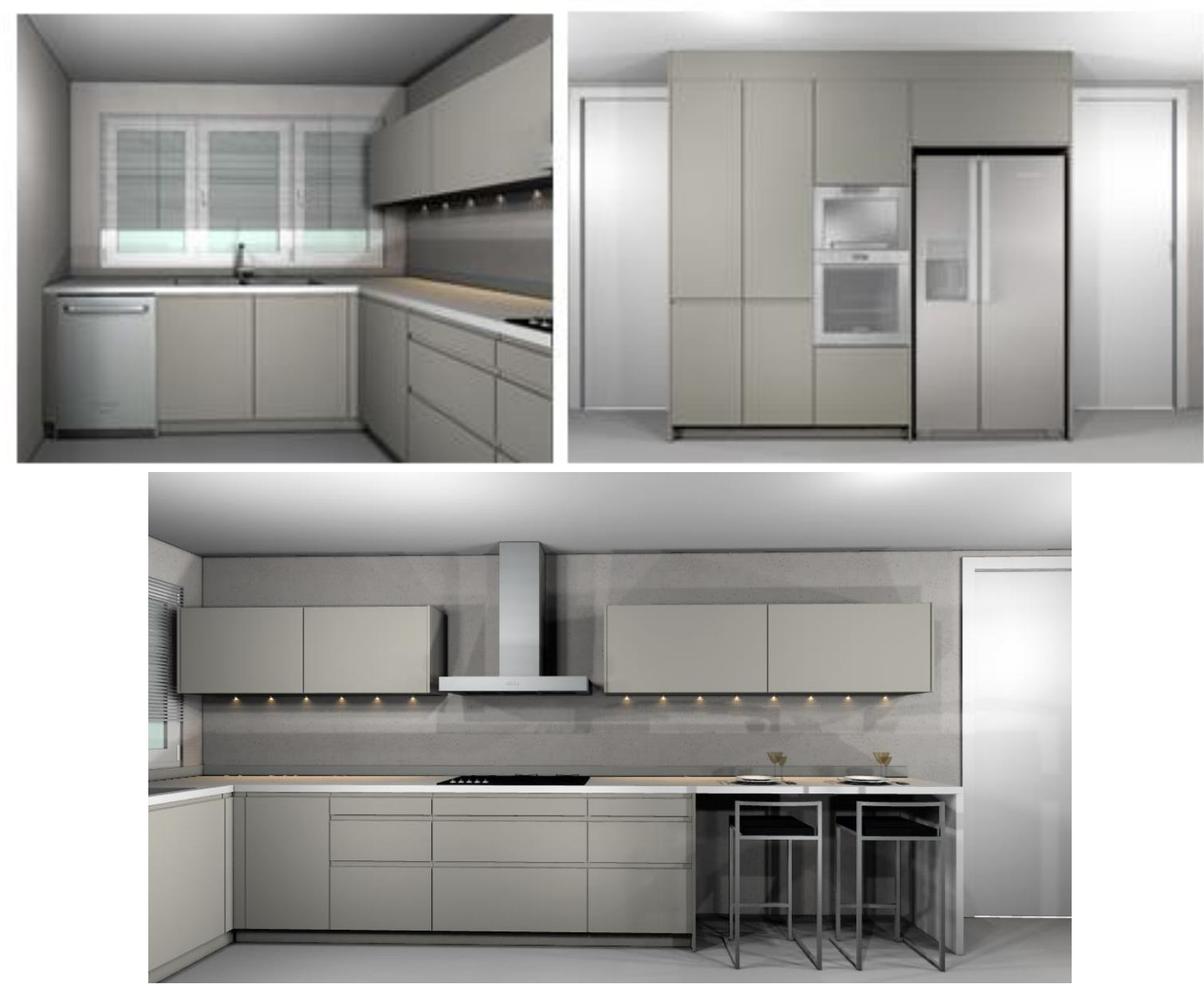

Fonte: Arquivo do autor. 


\subsubsection{Etapa de medição}

Uma vez aprovado este projeto e os valores negociados entre cliente e vendedor, com o pedido de venda emitido iniciam as etapas de pós venda. O próximo passo é a medição do local em que os móveis serão instalados, realizada pela figura do medidor, mas coordenada pelo vendedor, que organiza estes agendamentos conforme os prazos acordados com os clientes. Nesta etapa do processo é feito um levantamento métrico e fotográfico do imóvel, com anotações em planta e vistas de todos os elementos arquitetônicos que compõem o espaço, tais como paredes, portas, vãos, janelas, vigas, colunas estruturais, instalações elétricas e hidráulicas, que influenciarão na fixação e na distribuição dos módulos no espaço.

Figura 30a - Exemplo de planta baixa com o levantamento métrico realizado por medidor

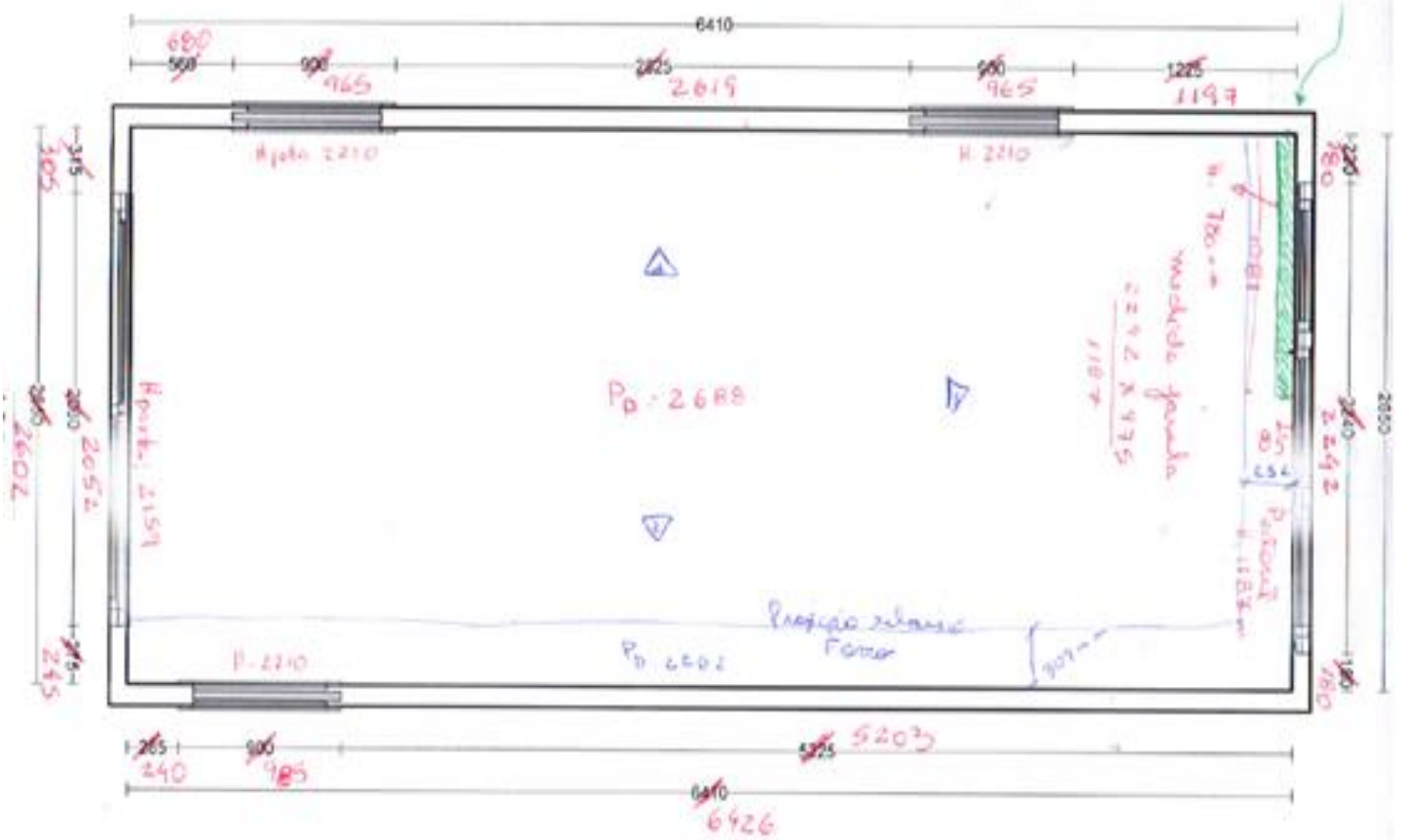

Figura 30b e 30c - Registro fotográfico da visita ao imóvel da figura 28
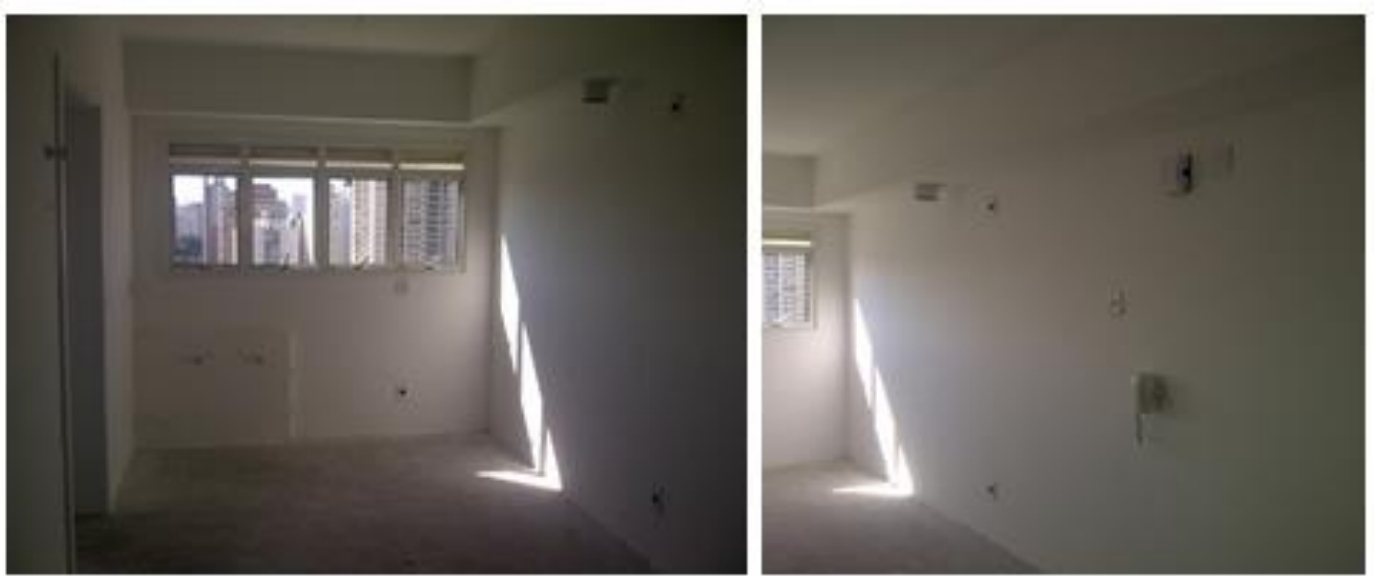

Fonte: Arquivo do autor. 


\subsubsection{Etapa de projeto técnico e vistoria}

Com o levantamento métrico e fotográfico realizado no imóvel, nesta etapa é feita a passagem das responsabilidades, entre a área comercial e o departamento técnico. Entretanto, antes de passar as informações do projeto técnico para os projetistas, em algumas empresas do ramo, o vendedor precisa fazer uma breve adequação da modulação, entre as medidas que foram consideradas em projeto para fins de orçamento e as que foram levantadas na etapa de medição. Em algumas empresas esta responsabilidade é exclusiva dos projetistas. Qualquer que seja a situação, o vendedor seleciona o arquivo com o projeto vendido e preenche uma espécie de formulário, que contém informações necessárias para o desenvolvimento do projeto, tais como a listagem com os modelos dos eletrodomésticos a serem considerados, o pé direito acabado, cores e acabamentos que foram vendidos, entre outras informações que foram acordadas com os clientes.

Com base nestas informações, os projetistas técnicos farão uma compatibilização formal do projeto, entre o que foi proposto no projeto inicial com as medidas reais do imóvel em que os produtos serão instalados. Este projeto técnico, mais conhecido como projeto executivo, é uma etapa fundamental no processo, pois quanto à relação comercial entre vendedor e cliente, é um documento que detalha graficamente os itens adquiridos na fase da venda. Quanto ao que se refere às questões técnicas do produto e a sua instalação, o projeto executivo indicará para a arquitetura e/ou para o cliente eventuais alterações a serem feitas na obra e que interferem diretamente nos móveis, tais como deslocamento de tomadas, mudanças hidráulicas para adequação de cubas, posicionamento de registro de gás para atender normas em vigor ou até solicitar novas instalações, para atender determinados tipos de eletrodomésticos, por exemplo. Ou seja, o projeto executivo considera todos os itens de uma cozinha, mesmo os que são parte do escopo de trabalho de outros fornecedores. No que se refere ao seu formato, este projeto executivo é impresso em folha A4 ou A3, em escalas métricas que variam entre $1: 25,1: 50$ ou 1:100 e possuem, em média, quinze páginas numeradas e uma capa, com os dados do cliente e endereço do imóvel.

Além da responsabilidade quanto à compatibilização técnica do projeto, de inicial para executivo, nesta etapa o projetista desenvolve outras atividades, uma vez que é o elo entre o comercial e a indústria. Entre tais atividades destaca-se o preparo da listagem de peças com os itens que deverão ser produzidos na fábrica e na organização da documentação para 
a etapa de montagem, que basicamente é um kit formado por esta listagem de peças com o projeto executivo.

Rosangela Nogueira (2016), gerente de projeto de móveis modulados destaca uma tendência que vem se consolidando nos últimos anos com o acúmulo de funções. Enfatiza que a figura do medidor, por exemplo, em muitas empresas já deixou de existir, ficando esta responsabilidade a cargo dos projetistas técnicos. Outra responsabilidade diz respeito às "peças especiais" - trata-se de alguns itens, que são comercializados nas lojas, mas que por limitação dos programas de desenho precisam ser feitos detalhes à parte do projeto, para que a indústria possa produzir tais peças com as dimensões e furações adequadas. Segundo ela, que trabalha no segmento desde 1997, esta função, que até poucos anos atrás era desempenhada nas indústrias pelos departamentos de engenharia, atualmente faz parte do escopo de trabalho dos projetistas. A estes fatores, Daniel Basso (2016), coordenador de projeto técnico em empresa de móveis modulados, identifica outras duas características na função, no cenário atual. Para o entrevistado, tem aumentado a quantidade de revisões nos projetos executivos. As revisões são alterações no projeto, por razões diversas que, segundo ele, vão desde mudanças na arquitetura, como alterações no modelo de determinado eletrodoméstico em detrimento do que havia sido inicialmente informado, ou inclusive por preferências pessoais dos clientes - situações que comprometem diretamente 0 cumprimento dos prazos e sobrecarregam o departamento. Aponta também que com o passar dos anos, à medida que o espaço da cozinha vem ganhando novas configurações, o projeto do mobiliário para este ambiente está ficando cada vez mais complexo, o que exige uma dedicação no projeto que muitas vezes não é compatível com o tempo disponível para este fim.

Considerando que, entre o projeto vendido, a produção dos módulos e a entrega dos móveis o prazo é de 45 a 60 dias úteis, além das responsabilidades acima mencionadas, o projetista precisa também fazer a administração de prazos, pois dele depende principalmente o envio da lista de peças para a produção industrial. De qualquer forma, assim que este projeto executivo estiver concluído, retorna para o vendedor que o assina com o cliente, formalizando o processo. Com o projeto executivo assinado pelo cliente, o projetista técnico encerra esta etapa e confirma o envio da lista de peças para a indústria, que produzirá o conjunto de itens da cozinha conforme esta listagem. 
Figuras 31 - Detalhamento de uma das vistas do projeto executivo referente à cozinha da figura 28

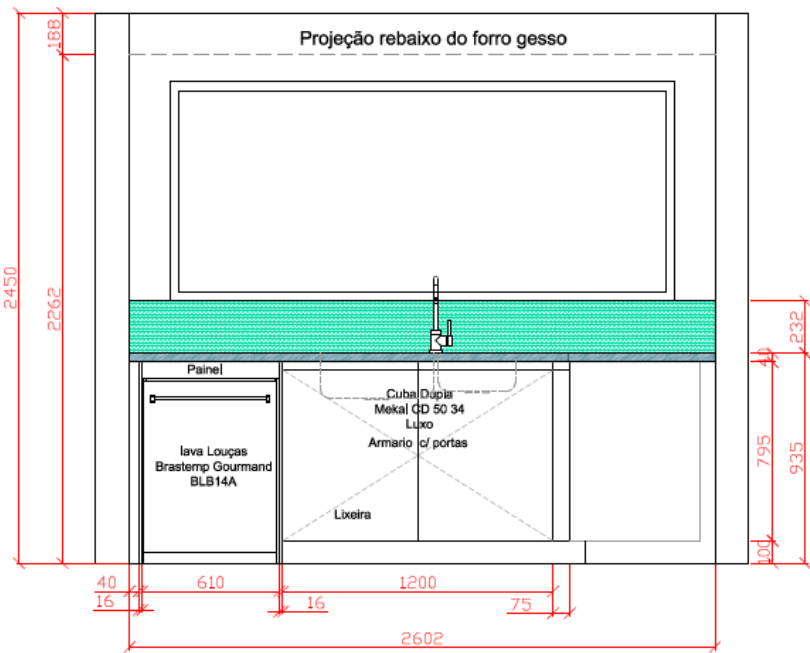

Fonte: Arquivo do autor.

Figuras 31 b - Detalhamento de uma das vistas do projeto executivo referente à cozinha da figura 28

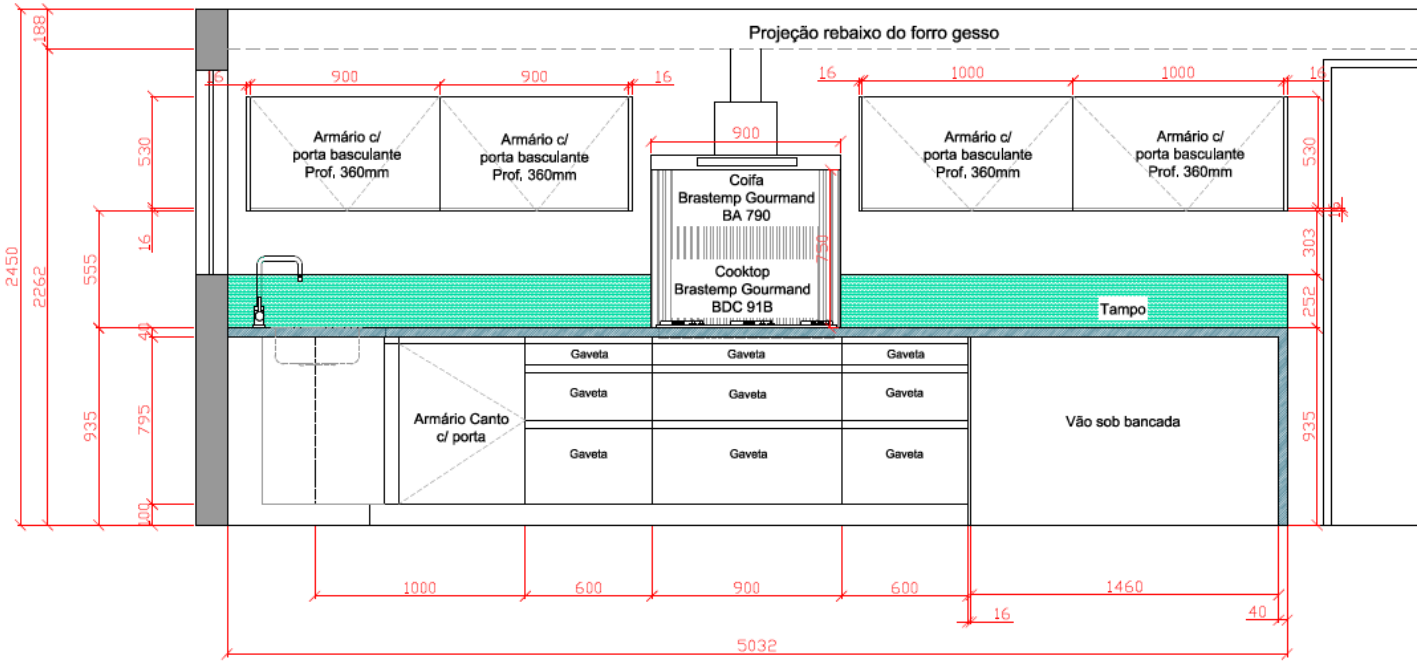

Fonte: Arquivo do autor.

Figuras 31c - Detalhamento de uma das vistas do projeto executivo referente à cozinha da figura 28

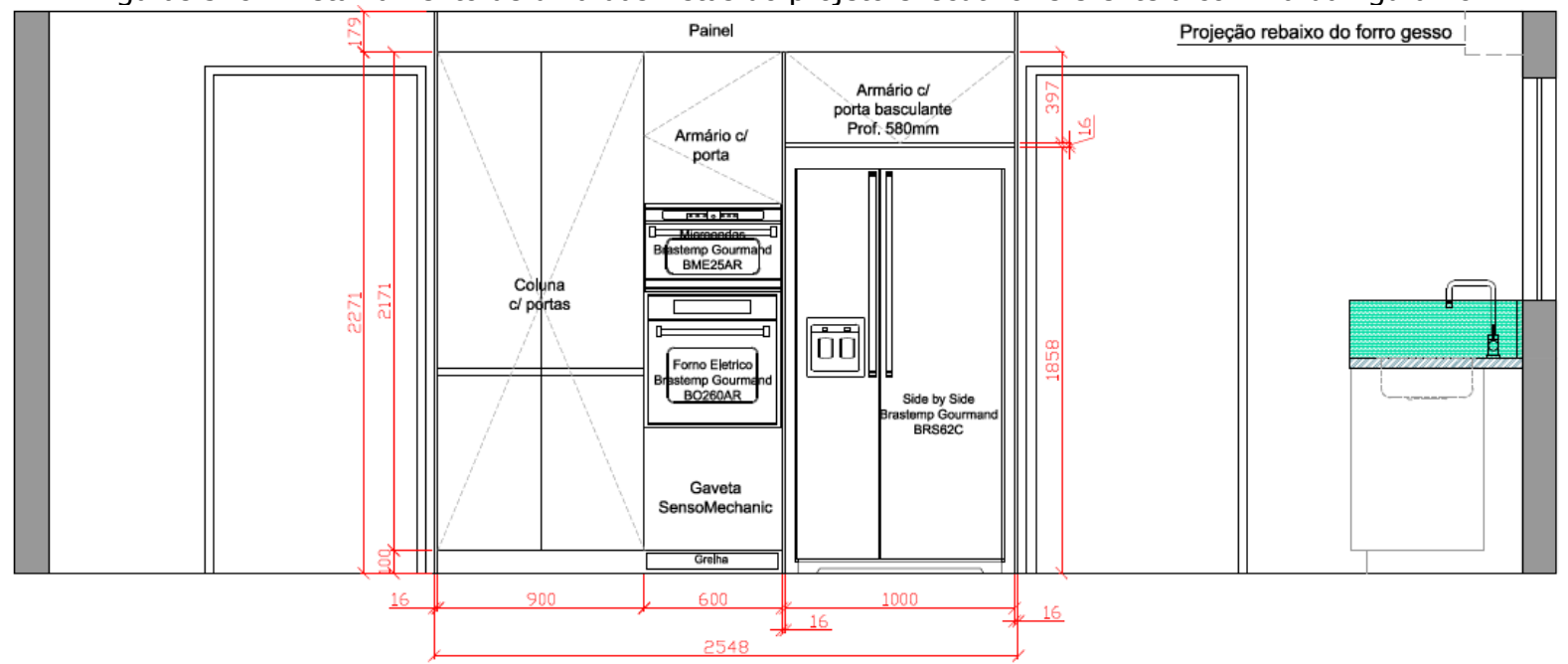

Fonte: Arquivo do autor. 
Figura 32a - Detalhamento de uma das vistas do projeto executivo referente à cozinha da figura 28 , com a solicitação das alterações elétricas, hidráulicas e de gás a serem realizadas na cozinha antes da montagem dos módulos

Fonte: Arquivo do autor.

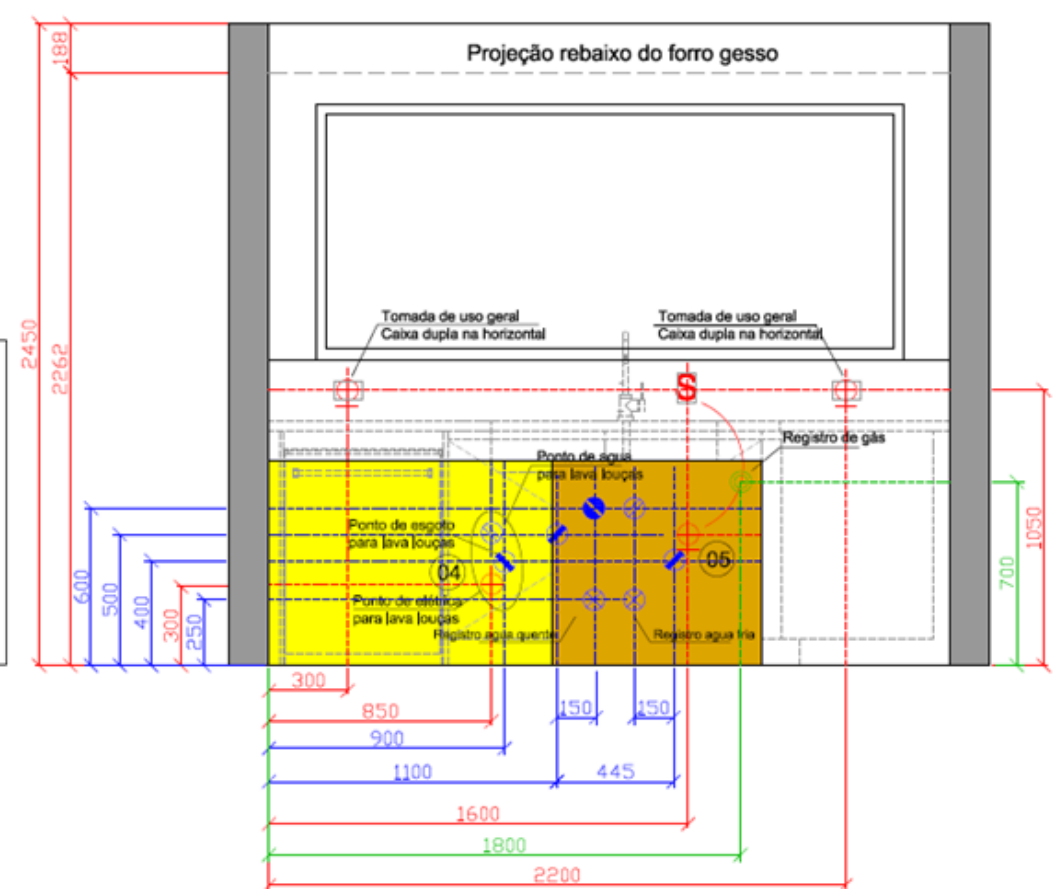

Figura 32b - Detalhamento de uma das vistas do projeto executivo referente à cozinha da figura 28, com a solicitação das alterações elétricas, hidráulicas e de gás a serem realizadas na cozinha antes da montagem dos módulos

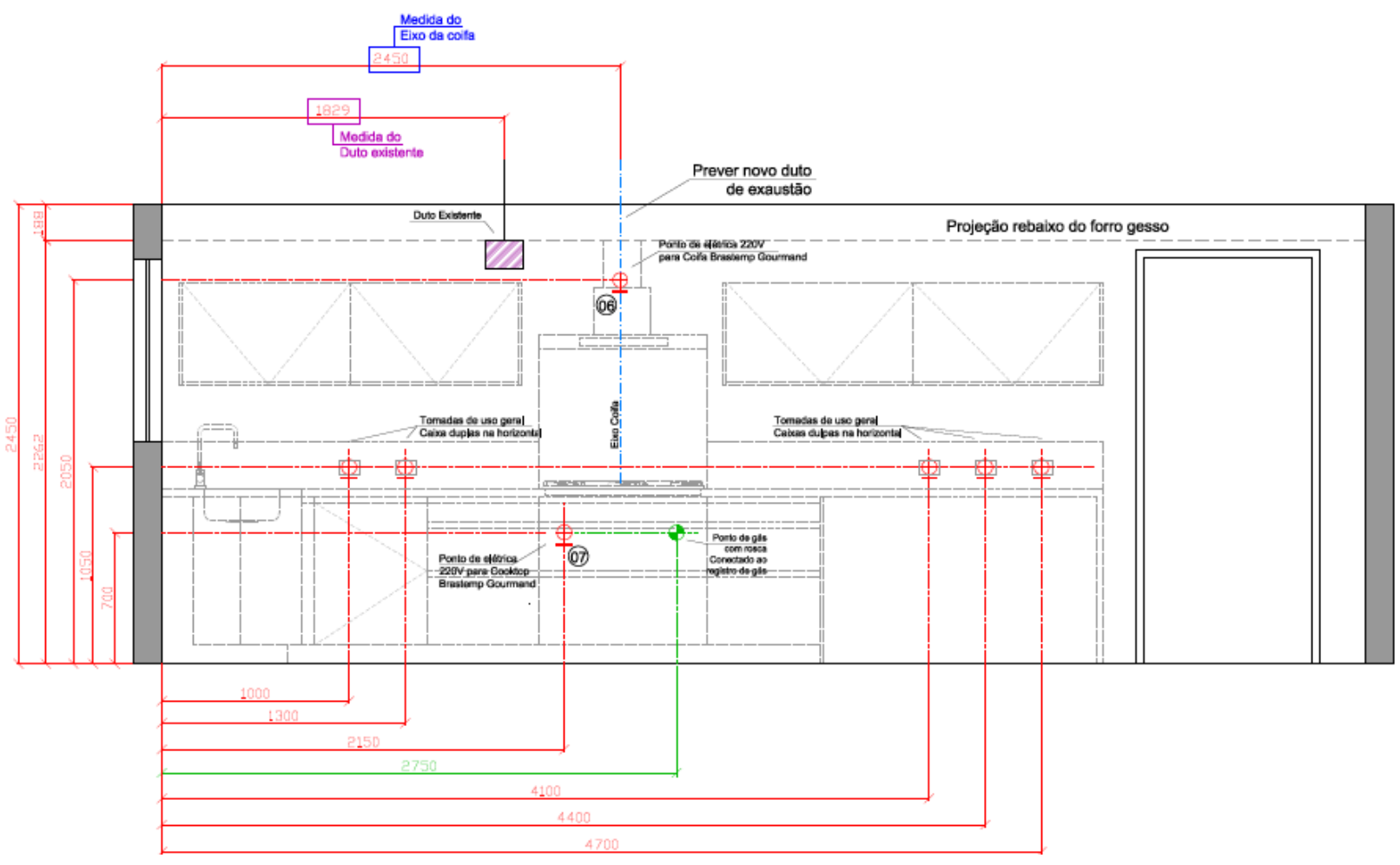

Fonte: Arquivo do autor. 
Desta forma, o projeto executivo de móveis para cozinhas é um documento importante que permeia todas as etapas posteriores à venda do produto, envolve muitos personagens no processo e executa os seguintes procedimentos:

- Formaliza o que foi vendido pelo vendedor e acordado com o cliente;

- Solicita para a arquitetura as eventuais alterações no espaço da cozinha, para adequação dos produtos;

- Relaciona a lista das peças que serão produzidas na fábrica;

- Indica ao vistoriador os itens que devem ser executados antes da montagem dos móveis;

- Orienta o montador quanto à instalação dos produtos no ambiente;

Sendo assim, este projeto deve conter:

- Medidas, acabamentos e a tipologia de todos os módulos e produtos que foram adquiridos, compatibilizados no espaço;

- Descritivo de ferragens e acessórios, tais como os que fazem parte de gaveteiros, por exemplo;

- Modelos dos itens fornecidos por terceiros, tais como eletrodomésticos, cubas e bancadas ou eventualmente outros itens que possam vir a interferir na instalação e uso dos módulos da cozinha;

- Indicação de eventuais alterações nas instalações arquitetônicas (elétrica, hidráulica, gás, rebaixos de gesso, vãos de portas, entre outros);

- Indicação de detalhes construtivos, que sejam necessários no momento da montagem, uma vez que para o montador, este é um documento instrucional;

Enquanto os móveis são produzidos pela indústria, uma nova visita é realizada pelo medidor ao imóvel, coordenada pelo projetista. Esta visita de vistoria tem por objetivo verificar se as alterações previstas em projeto executivo foram feitas em obra e se os ambientes estão prontos e em condições de receber os móveis para iniciar a montagem. Na figura seguinte é possível verificar o registro fotográfico da vistoria referente ao projeto vendido da figura 28 e acompanhar o andamento da execução das alterações elétricas, hidráulicas e de gás, solicitadas para a arquitetura (figuras 32 "a" e "b"). 
Figuras 33a - Registro fotográfico de vistoria feita no imóvel referente à cozinha da figura 28

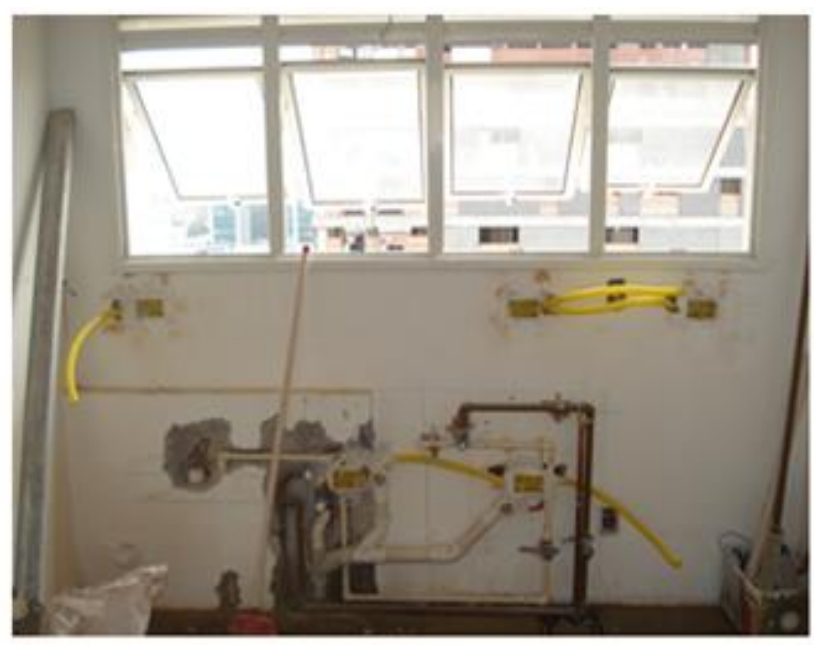

Figuras 33b - Registro fotográfico de vistoria feita no imóvel referente à cozinha da figura 28

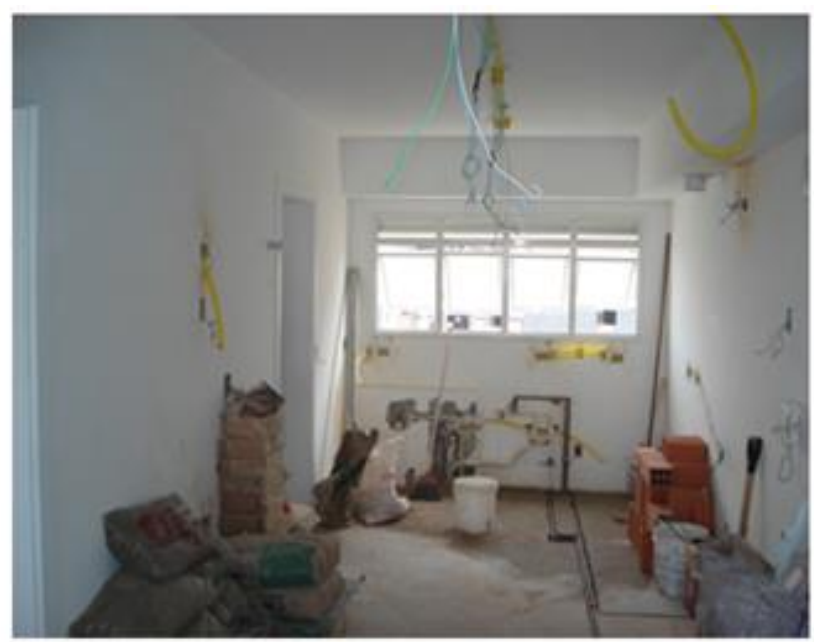

Figuras 33c - Registro fotográfico de vistoria feita no imóvel referente à cozinha da figura 28

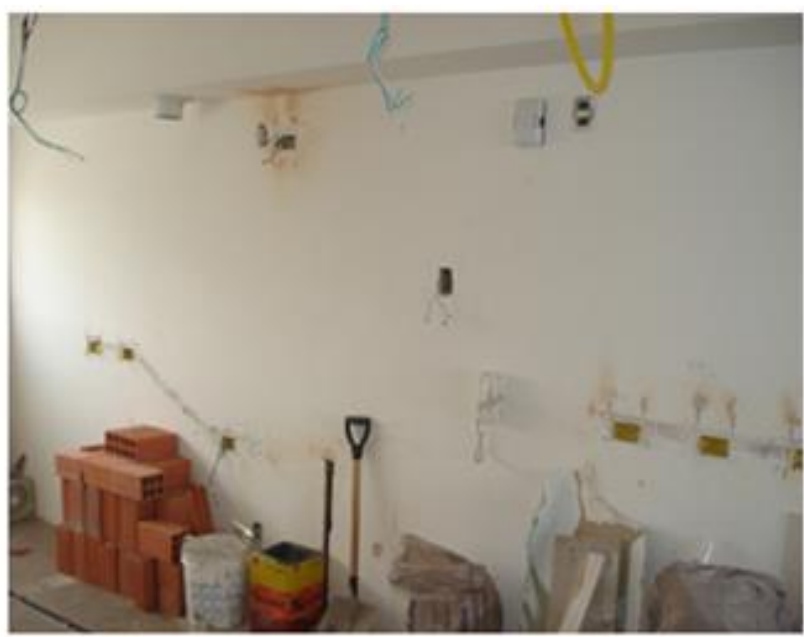

Fonte: Arquivo do autor. 


\subsubsection{Etapa de produção industrial}

$\mathrm{Na}$ indústria, os pedidos são recebidos pelo setor de engenharia que à partir de um software gráfico tem-se o desenho do módulo, com todas as medidas de largura, altura e profundidade e espessura dos painéis que irão compor cada módulo de cozinha. Em um segundo momento, baseado na lista de peças do projeto, é feito o que se chama de "explosão" do produto, desmembrando as partes que o compõe. Por meio do analista de planejamento e controle de produção (PCP) é feito o controle operacional da produção dos móveis, dividindo-a por lotes que organizam volume de peças acabamentos dos móveis, controle do estoque, compra de materiais e até mesmo pedidos que precisem ser entregues e produzidos em prazos menores.

Um dos recursos utilizados nesta etapa pré-produção é o plano de corte: é um cálculo de aproveitamento de matéria prima que considera a melhor maneira de aproveitar o material e com o menor desperdício possível, define Joerly Santos (2016), diretor de produto da empresa Corte Certo, que comercializa o software de plano de corte para empresas e indústrias de diversos segmentos. Ele complementa afirmando que o plano de corte pode ser utilizado em qualquer material e em qualquer tipo de superfície, retilínea ou não. Da mesma forma, o plano de corte pode ser utilizado no cálculo de aproveitamento da matéria prima para a produção dos mais variados tipos de produtos, de móveis a aviões.

Figura 34: Alguns exemplos de materiais que possibilitam o plano de corte, como painéis de madeira, chapas de aço, tecidos e vidros

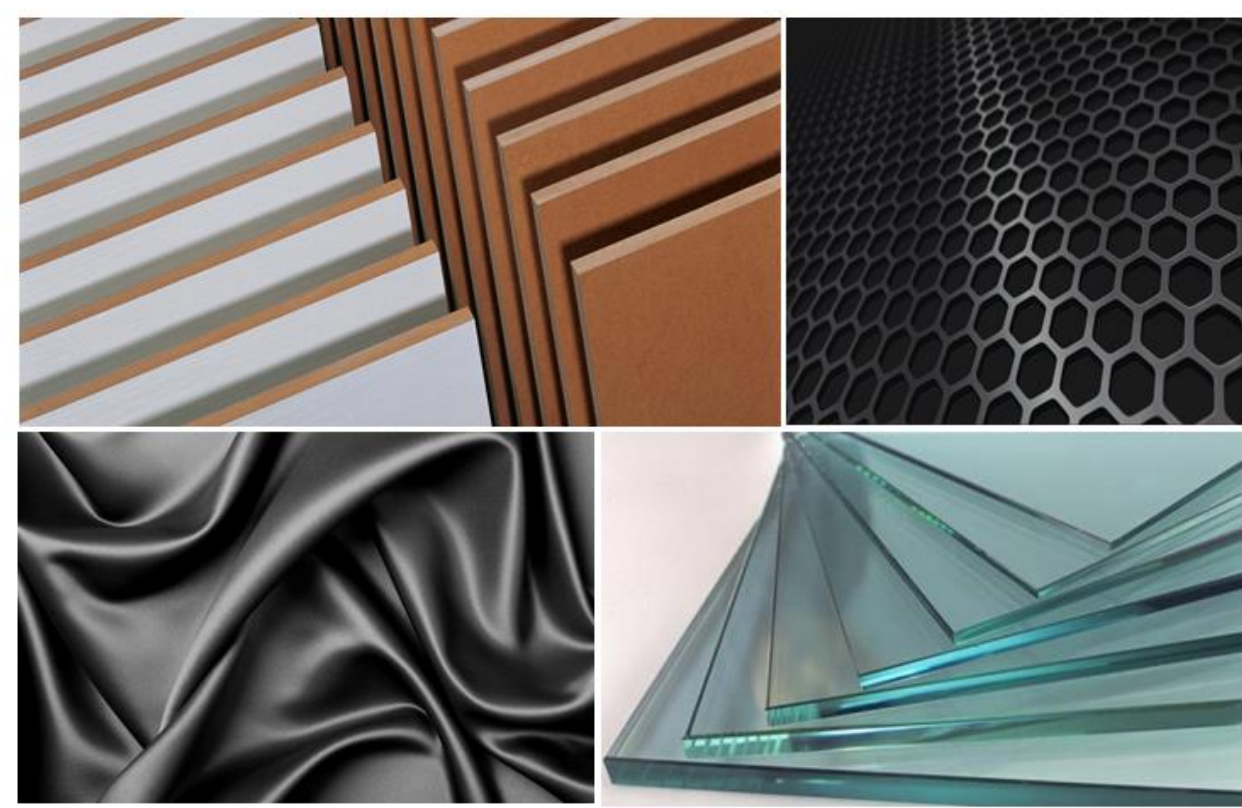

Fonte: Diagrama elaborado pelo autor da Dissertação. 
Atualmente, segundo Santos (2016), este planejamento, ou plano, como é denominado, é feito por meio de softwares especializados, entretanto, relata casos de cálculos feitos manualmente. Quando realizado por meio de recursos eletrônicos, o plano de corte fará um cruzamento entre as dimensões da matéria prima e as peças que precisarão ser produzidas, para que desta equação resulte um percentual de aproveitamento que a indústria comumente chama de "lógico". Naturalmente, este percentual varia de acordo com a indústria, tipo de produto e o processo industrial, entre outros fatores.

Na figura abaixo é representado um exemplo de plano de corte em um painel de MDF de medidas 1840 × $2750 \mathrm{~mm}$ - as partes numeradas são as partes de um módulo de cozinha, que podem ser suas laterais, base, fundo, porta, ou qualquer outro componente. As partes não numeradas e identificadas na cor amarela (à esquerda) e na cor azul (na barra inferior) são partes que não serão aproveitadas, resultando em descarte de material excedente de produção. Ainda que neste caso o painel não seja aproveitado em sua totalidade, do ponto de vista industrial, de produção de móveis em grande escala, este é um bom exemplo de plano de corte, pois possui apenas duas fases, o que facilita o processo de corte automatizado pelas máquinas. Fase, sob este ponto de vista, significa o giro, o movimento que precisará ser feito na superfície, para corte do material. Indicado pelas setas na cor branca nota-se na figura abaixo que a etapa de corte deste painel é relativamente simples, pois o movimento da máquina será contínuo.

Figura 35: Exemplo de plano de corte com duas fases, em painel de MDF (vista superior)

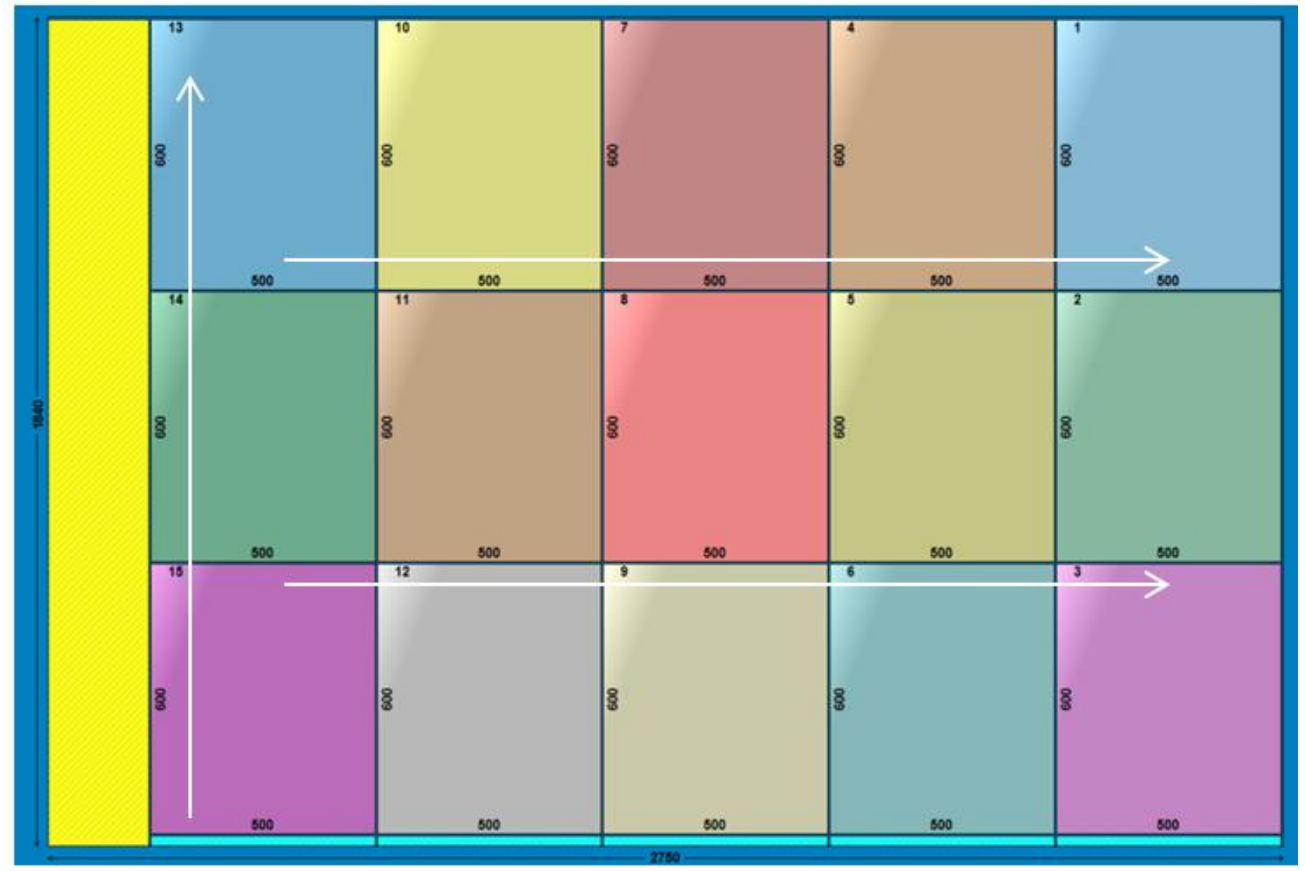

Fonte: www.cortecerto.com.br/telas. Acesso em 17 nov. 2016. Imagem adaptada pelo autor da Dissertação. 
Na figura seguinte, é feita uma demonstração de plano de corte em um painel de MDF com medidas idênticas ao da figura 35. Neste exemplo, o plano de corte é feito de forma a aproveitar o material em sua totalidade, porém, por conta das múltiplas fases que não são coordenadas e contínuas, o processo de corte deste painel pelas máquinas será lento, pois exigirá que o operador da máquina realize muitas manobras no material.

Figura 36: Exemplo de plano de corte com múltiplas fases, (vista superior)

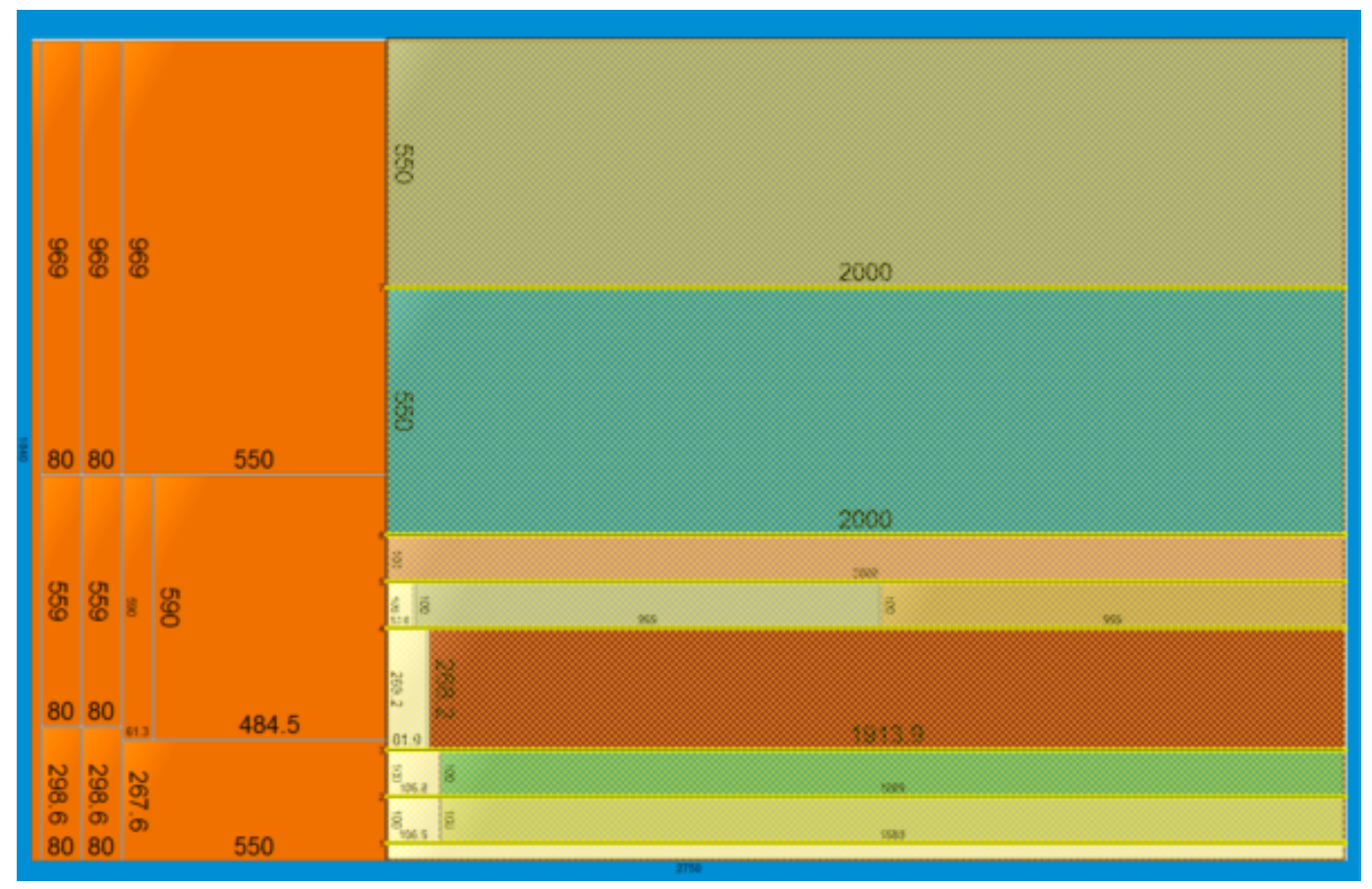

Fonte: www.cortecerto.com.br/telas. Acesso em: 17 nov. 2016.

Assim, pode-se concluir que a equação aproveitamento de materiais x planos de corte precisa considerar os recursos disponíveis de capital humano, maquinário e tempo, pois, como observado nos dois exemplos anteriormente apresentados, a economia somente de materiais não será suficiente se isto acarretar outros custos no processo. Da mesma forma, o plano de corte é uma etapa fundamental no processo industrial, talvez uma das mais importantes, pois a partir dele é gerado boa parte do descarte pré-consumo industrial.

A partir das características dos projetos dos produtos a serem produzidos e os parâmetros definidos de aproveitamento dos materiais no plano de corte, realizam-se a seleção dos painéis de madeira na área de armazenagem, para iniciar a produção dos móveis. Este transporte dos painéis de madeira até às esteiras varia conforme a indústria e pode ser feito manualmente, por empilhadeiras elétricas, a gás ou por robôs pneumáticos, como ilustrado na figura 37. 
Figura 37 - Foto interna em indústria de móveis para cozinha, da área de armazenagem de painéis de MDF e MDP que serão selecionados para início da produção

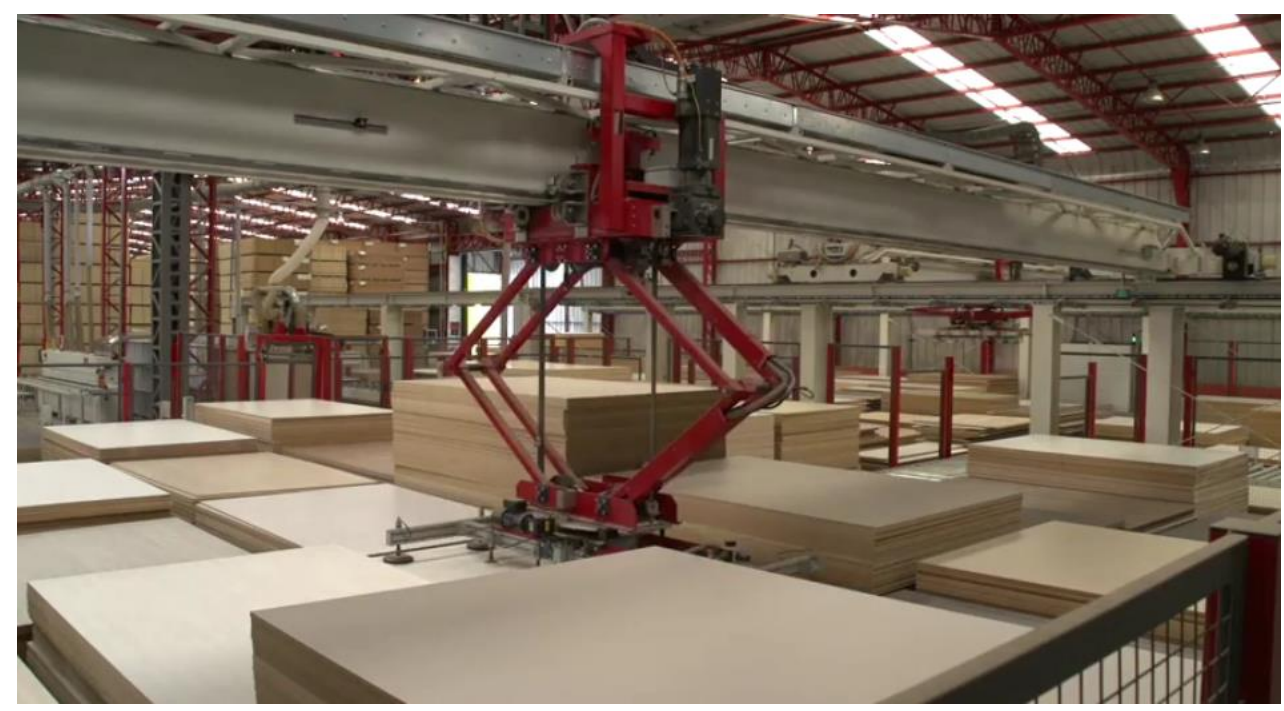

Fonte: http://www.unicasamoveis.com.br/sobre. Acesso em: 02 nov. 2015

Considerando que estes painéis de MDF e MDP originalmente possuem grandes dimensões, o processo de corte nas indústrias de móveis ocorre em pelo menos dois momentos. Primeiro, assim que os painéis chegam dos fornecedores (tais como Duratex, Masisa, Fibraplac, entre outros), são refilados para a retirada de imperfeições de suas bordas, processo que será mais detalhado no item 4.2. (pág. 79). Com a superfície pronta, um segundo processo de corte divide os painéis em partes menores, de acordo com 0 aproveitamento definido no plano de corte e que resulta, por exemplo, nas partes dos módulos, tais como base, lateral, fundo, portas, entre outras peças. Este processo, assim como o processo antecedente de refilamento das bordas, é realizado via seccionadora, por conta do tamanho e abertura da máquina, o que permite o corte do painel inteiro. Da mesma forma, estas partes menores resultantes do corte dos painéis via seccionadora, quando houver a necessidade de sua redução em outras partes menores será utilizado a esquadrejadeira, que por ser uma máquina menor, é mais adequada a este processo.

Ainda na etapa de produção, cada parte ou seção do móvel receberá uma usinagem, que pode ser realizada via Computer Numeric Control $(\mathrm{CNC})^{8}$, fresadora ou furadeira múltipla, variante conforme o grau de automação da indústria e o resultado que se pretende atingir. Esta usinagem refere-se tanto à produção de rebaixos para encaixes do fundo dos módulos em suas laterais, por exemplo, quanto para obtenção de resultados puramente estéticos, quando se opta por frisos decorativos na superfície.

\footnotetext{
${ }^{8}$ CNC: Comando numérico computadorizado, tradução livre do inglês.
} 
Figura 38 - Painel de MDP no início do processo de refilamento das bordas, realizado por seccionadora industrial

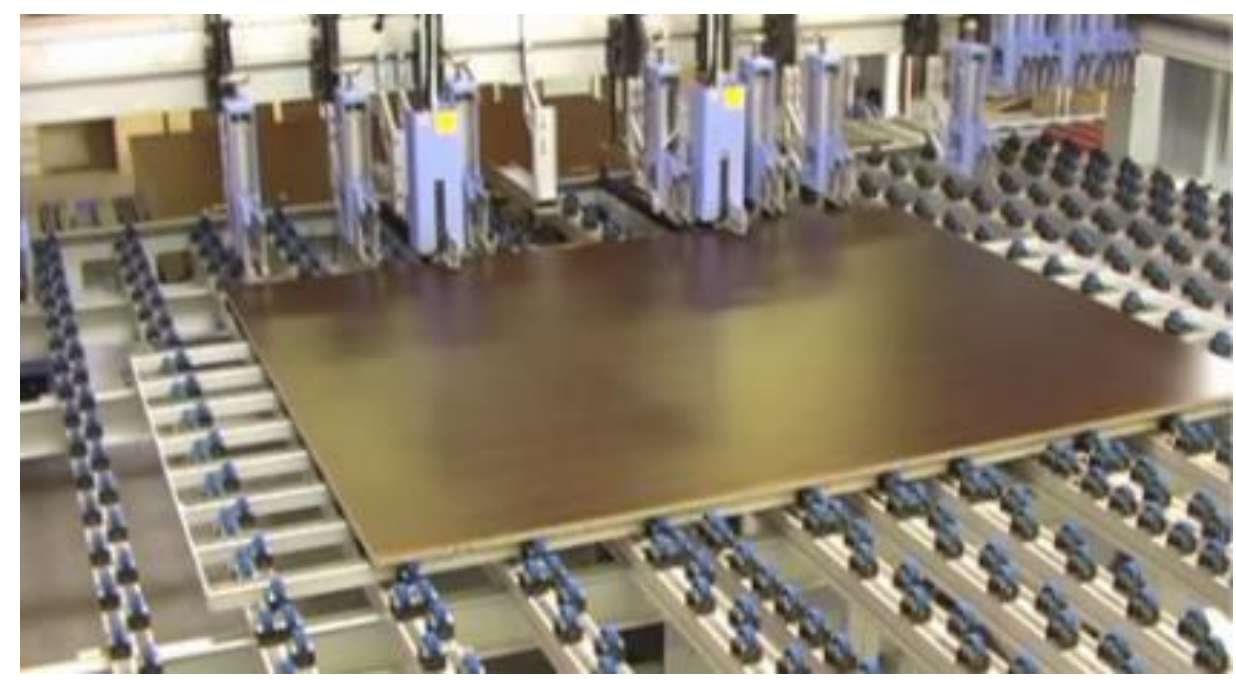

Fonte: http://www.homag.com.br/pt/products/productdatabase/Pages/holzmaseries5hpl530.aspx Acesso em 22 fev.2017.

Figura 39 - Detalhe de corte de painel de madeira reconstituída em seccionadora industrial

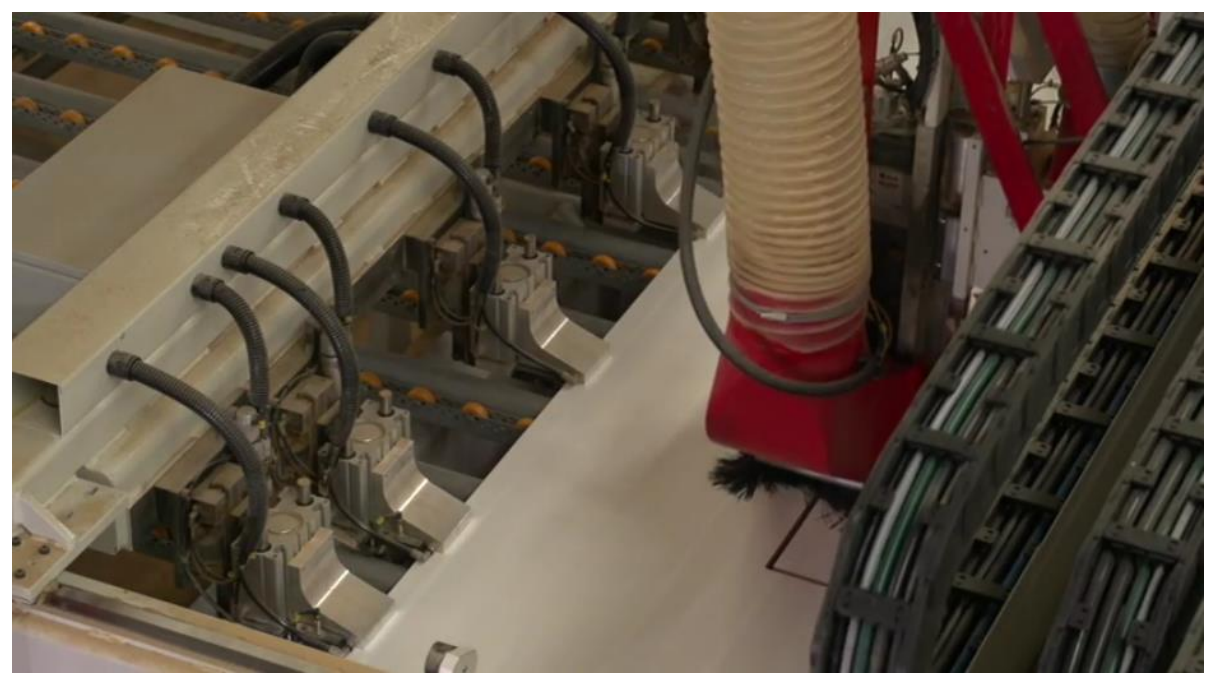

Fonte: http://www.unicasamoveis.com.br/sobre. Acesso em: 02 nov. 2015

Fabio Nakano (2015) técnico de produção em indústria de móveis para cozinhas aponta que outra característica quanto ao corte dos painéis é que, na grande parte dos produtos modulados para cozinha, os painéis são comprados dos fabricantes já revestidos com laminado de baixa pressão (BP) nos padrões definidos pelas indústrias de móveis. A vantagem dos painéis serem entregues revestidos, segundo este profissional "é que se pula a etapa de prensa e colagem nos painéis sem revestimento, o que agiliza a produção e garante melhor acabamento, pois será feito por empresas e máquinas apropriadas". Alguns painéis em MDF são comprados sem revestimentos e são adequados somente ao processo de pintura. 
A etapa de prensa e colagem de revestimento é uma opção utilizada por algumas indústrias que, em substituição ao laminado de baixa pressão (BP), utilizam o laminado de alta pressão (AP) por uma questão estratégica de diferenciação do produto frente à concorrência. Segundo o fabricante Madepar (2017), na comparação entre os dois revestimentos, por conta do seu processo de prensa e colagem, o laminado AP proporciona maior resistência à superfície (ver figura 10, capítulo 2, pag. 33). Nota-se que a inclusão deste processo referese somente às superfícies visíveis do produto, tais como tamponamentos, portas e frentes, mantendo-se toda a caixaria dos módulos em BP. Da mesma forma, este processo só é possível após o corte dos painéis via seccionadora, pois as máquinas de prensa consideram a largura dos laminados, que variam entre 1200 a $1300 \mathrm{~mm}$ e os painéis de MDF e MDP possuem originalmente a medida de $1840 \times 2750 \mathrm{~mm}$.

De qualquer maneira, tanto no caso de revestimentos laminados de baixa pressão (BP) ou de alta pressão (AP) há a necessidade de aplicação da borda em PVC, dos quatro lados dos painéis. A borda tem a função de dar acabamento e selar as peças, protegendo o seu interior de umidade e choques. Assim como os painéis de MDF e MDP possuem acabamentos e espessuras variados (tais como 12, 15, $18 \mathrm{~mm}$ ), a borda deve possuir as mesmas variáveis, o que torna complexa a cadeia de suprimentos na indústria, pois o fornecedor das bobinas com a fita de borda é diferente do fornecedor dos painéis, mas os acabamentos precisam ser idênticos. As máquinas que realizam esta operação são denominadas coladeiras de borda, e em alguns casos também se encontra a denominação bordatrice ou filetadeiras, referindo-se ao mesmo produto.

Figura 40 - Fitas de borda sendo aplicado em painéis de madeira

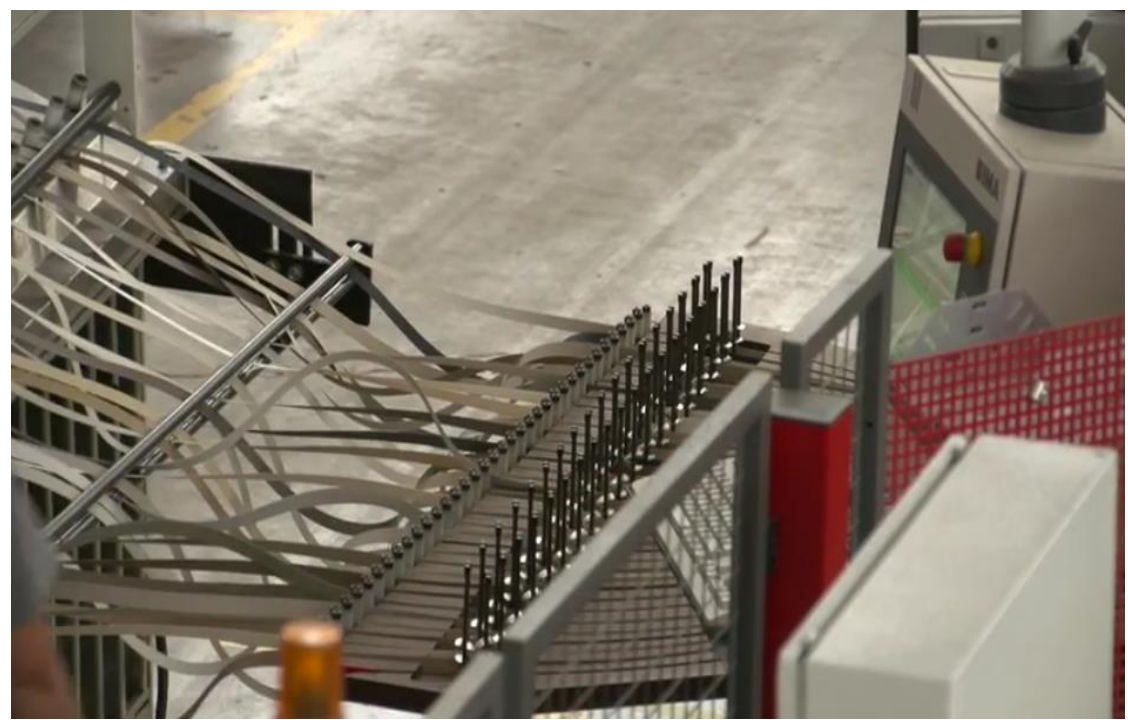

Fonte: http://www.unicasamoveis.com.br/sobre. Acesso em: 02 nov. 2015. 
Estas coladeiras de borda podem ser encontradas em versões manuais, mais comum em empresas de pequeno porte e pequenas marcenarias e automáticas. Algumas versões automáticas colam os dois lados ao mesmo tempo e outras são unilaterais. Outro dado importante é que o bocal para colagem dos dois lados é de $120 \mathrm{~mm}$ - peças menores precisam passar na máquina duas vezes.

Figura 41 - Detalhe de painéis em MDP com revestimento laminado e fita de borda aplicada, garantindo o acabamento no topo dos painéis

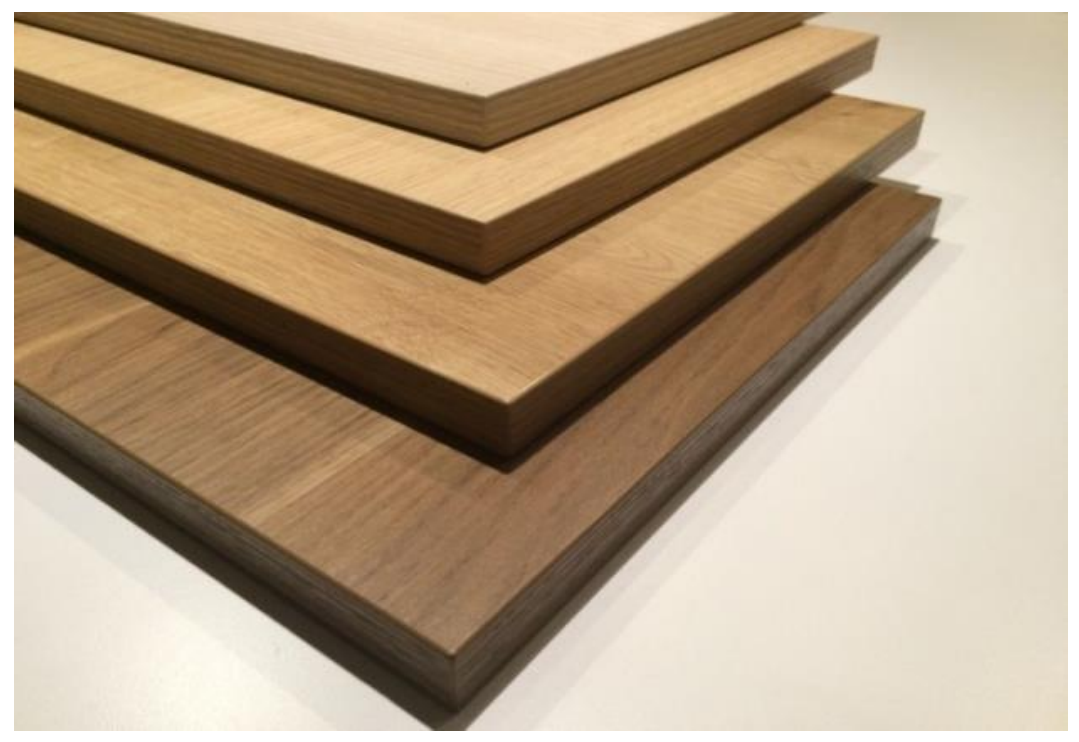

Fonte: Arquivo do autor.

Da mesma forma, em caso de peças pintadas, os painéis em MDF em seu aspecto natural e sem revestimento após serem seccionados e usinados, são encaminhados para os setores de pintura dentro da fábrica. De maneira geral, as etapas de pintura epóxi envolvem:

- Aplicação de primer para o preparo da superfície;

- Lixamento dos painéis de MDF, para a correção de imperfeições;

- Aplicação de pintura, até chegar à tonalidade definida;

- Polimento, no caso de acabamento alto brilho;

É importante destacar que esta etapa de pintura acontece nas indústrias de móveis que possuem cabine de pintura e atendem às legislações ambientais específicas a este processo. Há também no mercado indústrias de móveis para cozinhas que possuem em seus catálogos de produtos superfícies pintadas, entretanto este processo de pintura é terceirizado, realizado por outras indústrias especializadas, como a Finotoc, por exemplo. Tais empresas terceirizadas já fornecem as peças prontas de acordo com as dimensões e acabamentos definidos pelas indústrias de móveis. 
Nestes casos, ao término do processo de pintura, estas peças prontas são entregues embaladas nas indústrias de móveis, para serem agrupadas aos demais itens da cozinha e transportadas até os locais de montagem em um único frete.

Figura 42a - Superfície de MDF em processo de pintura epóxi

Figura 42b - Portas em MDF com a superfície pintada
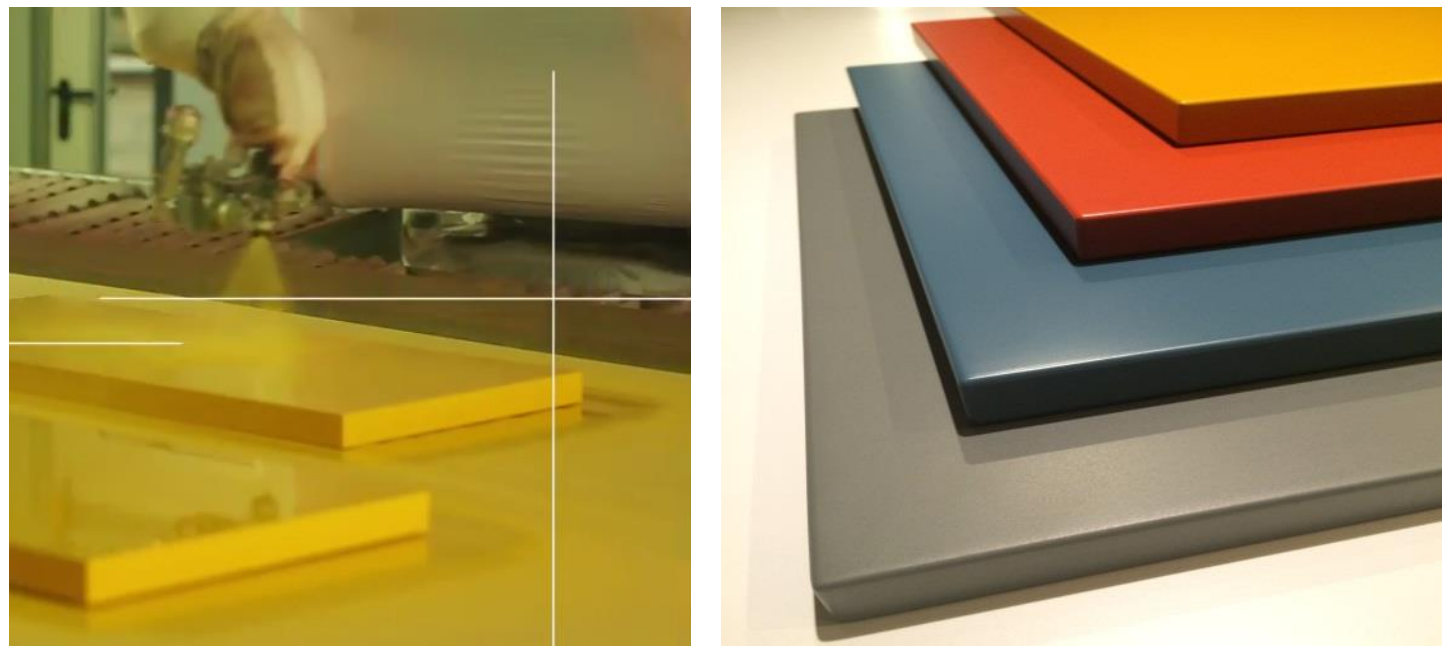

Fonte: http://www.unicasamoveis.com.br/sobre. Acesso em: 02 nov. 2015

Fonte: Arquivo do autor.

A etiquetagem e identificação das peças é outro processo que acontece em momentos diferentes na etapa de produção. À medida que os painéis de MDF e MDP são cortados na seccionadora, são coladas etiquetas de produto sobre as partes resultantes do corte, para identificação do lote de produção ao qual pertencem. Da mesma forma, esta identificação se repete no final do processo com a etiqueta de embalagem, que identifica número do pedido e nome do cliente.

Figura 43 - Etiquetagem e identificação das partes de um módulo

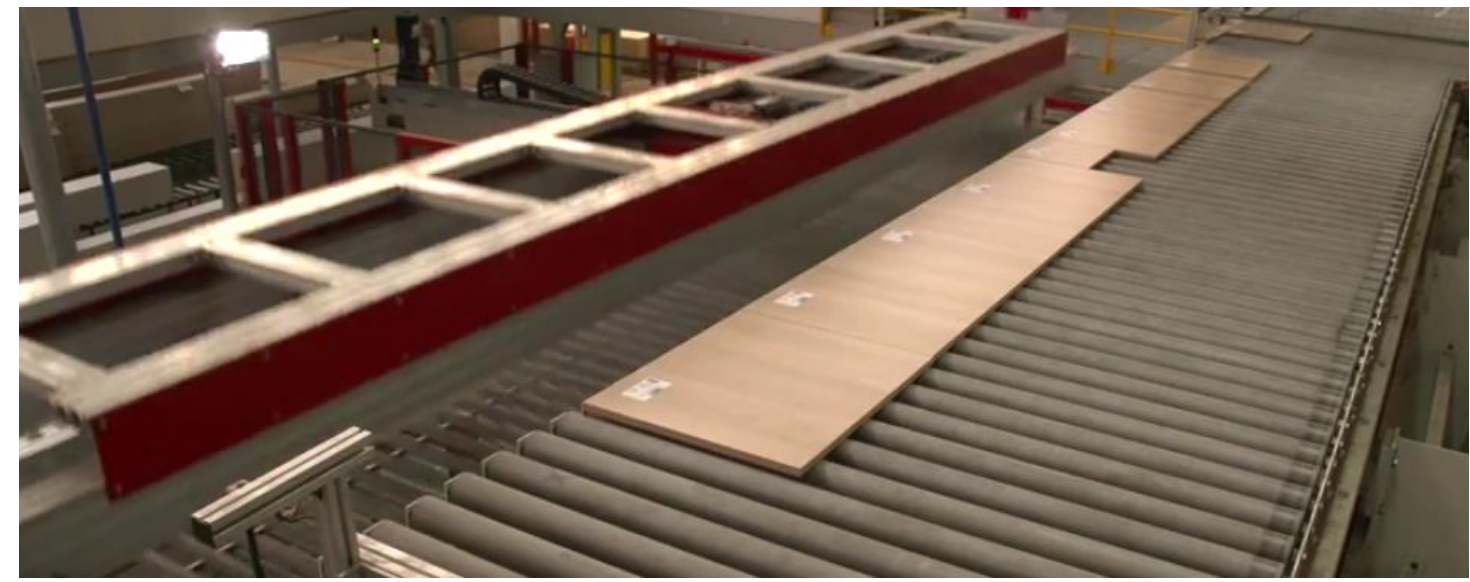

Fonte: http://www.unicasamoveis.com.br/sobre. Acesso em: 02 nov. 2015 
Uma das últimas etapas dentro da indústria é a separação das peças por pedido de cliente. Nesta etapa também é feito um controle de qualidade e somado ao pedido um kit de ferragens (para a montagem) e acessórios (conforme aquisição do cliente). Todas estas peças formam um conjunto que é encaminhado ao setor de expedição. Nas indústrias de médio e grande porte investigadas, esta fase final é um dos poucos momentos em que é possível identificar processos não automatizados, e que dependam exclusivamente de capital humano, por duas razões principais: a primeira refere-se à montagem do kit de ferragens, que vem de fornecedores variados e precisam ser separados para atender aos pedidos isoladamente. A segunda razão refere-se ao controle de qualidade que depende de uma análise visual e tátil da superfície dos produtos.

Figura 44 - Separação das peças ao final da produção

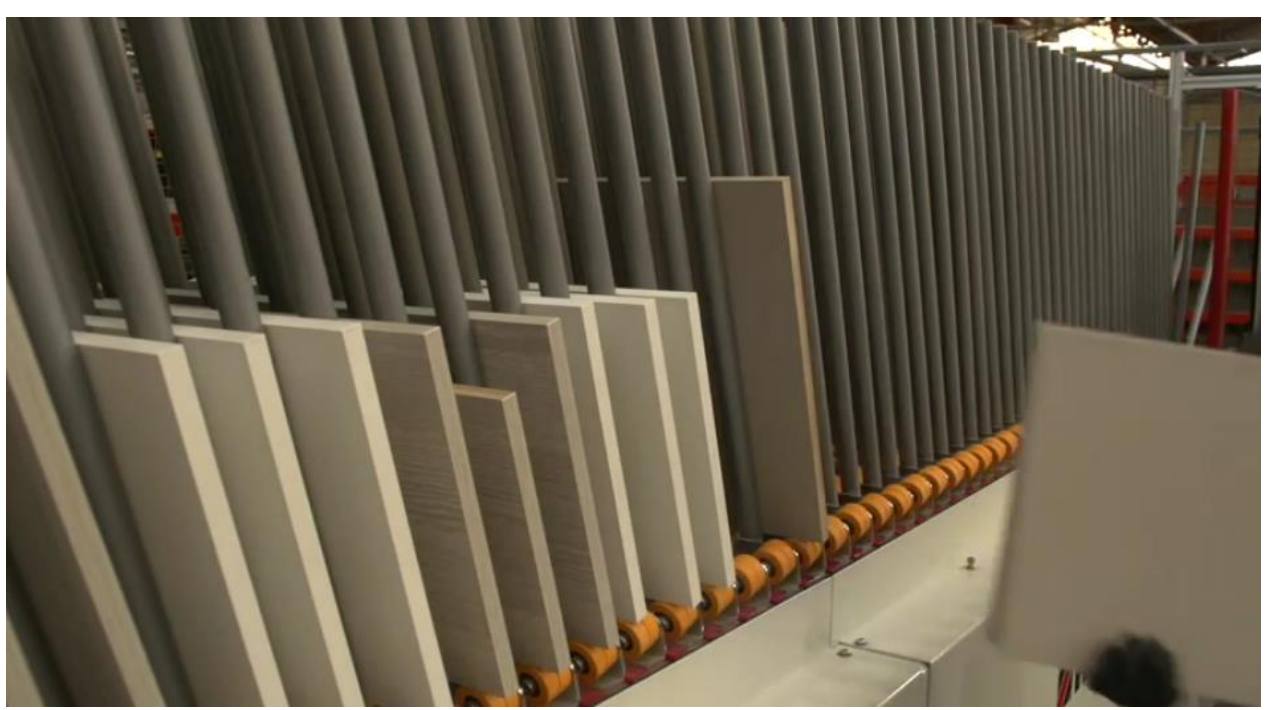

Fonte: http://www.unicasamoveis.com.br/sobre. Acesso em: 02 nov. 2015

Nas indústrias de móveis para cozinha investigadas, foi possível perceber dois cenários distintos nesta fase do processo: em alguns casos, os módulos são pré-montados dentro da indústria, com suas partes unidas por cavilhas de madeira e prensadas em máquinas industriais específicas, que esquadram o produto. Em outros casos, todas as partes que compõem o conjunto de produtos da cozinha seguirão desmontadas até os locais de instalação, sendo unidas por cavilhas e rotofix no momento da montagem. Em qualquer situação, os produtos são embalados e encaminhados para o setor de expedição, aguardando a coleta pela transportadora. Em grande parte dos casos analisados, os produtos são enviados das indústrias de móveis para os centros de distribuição e logística mais próximos das lojas, para que seja organizado um novo transporte até os locais de montagem das cozinhas. 
Nota-se na figura seguinte que todas as partes que compõem os produtos são embaladas, têm as bordas protegidas com manta de polietileno expandido (isomanta), e protetores nas quinas.

Figuras $45 a$, b e c - Carregamento de peças para a montagem de módulos de cozinha
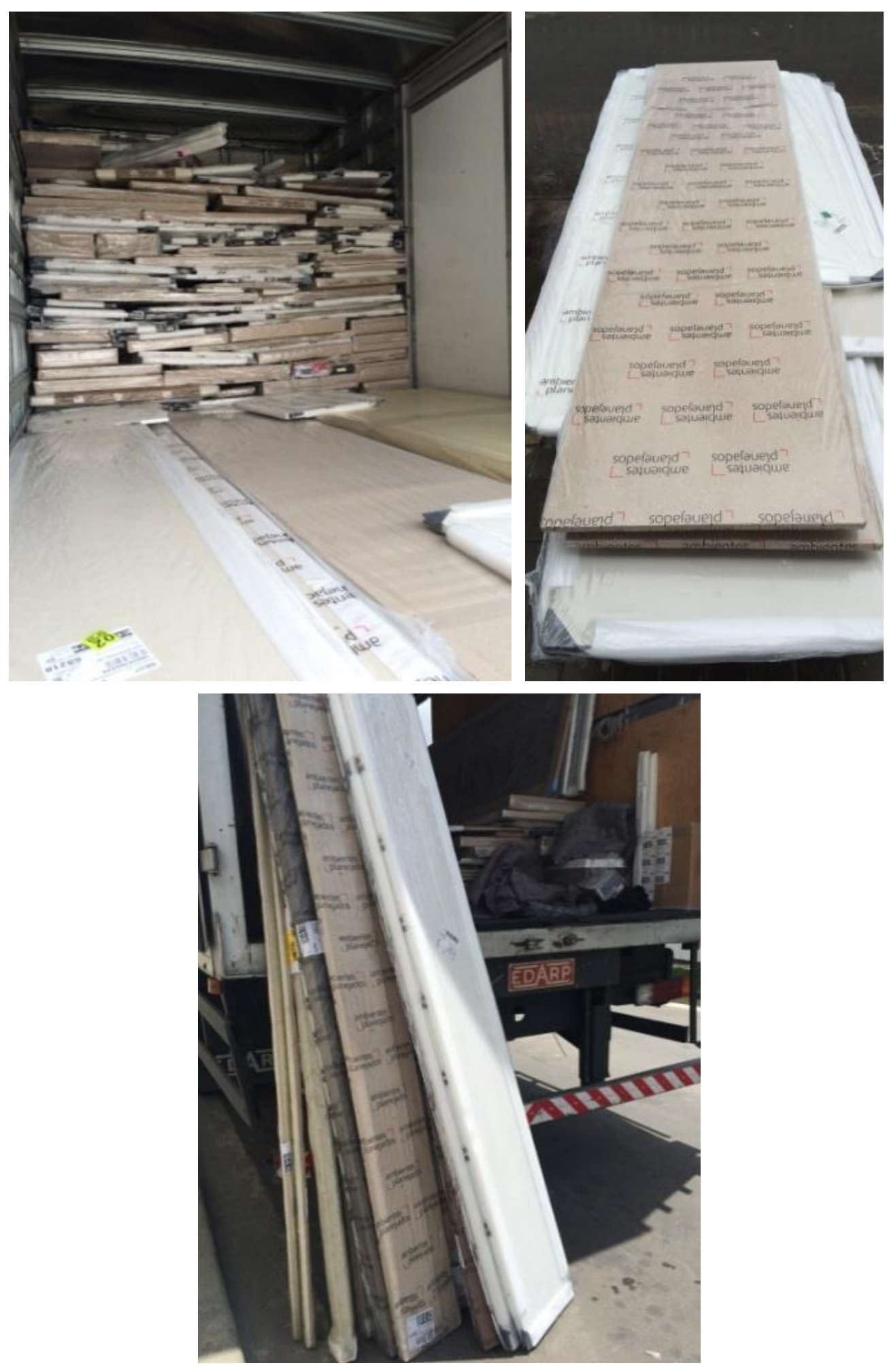

Fonte: Arquivo do autor 
Figura 46 - Diagrama circunstanciado da produção industrial de móveis modulados para cozinha em indústrias de médio e grande porte

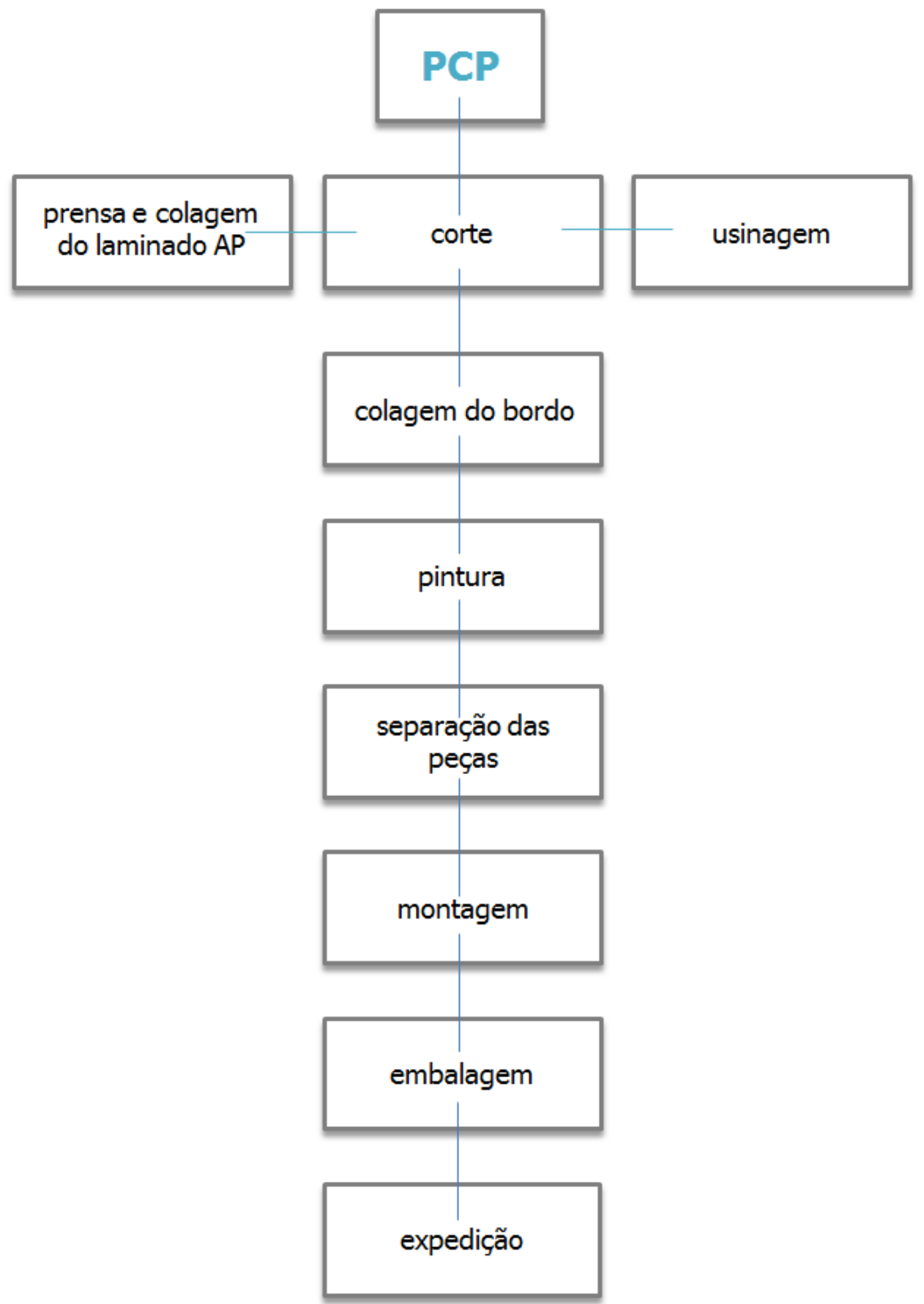

Fonte: Diagrama elaborado pelo autor da Dissertação. 


\subsubsection{Etapa de montagem}

Com o ambiente da cozinha pronto, vistoriado e as peças entregues, a montagem dos móveis é iniciada. Na maior parte dos casos a montagem é feita em duplas, um montador mais experiente e um ajudante, o que permite um trabalho ágil, sem sobrecarga aos empregados, evitando acidentes e a danificação dos produtos, que por vezes são peças grandes e o espaço de movimentação nos locais de montagem é reduzido.

Em posse do kit de montagem, que é o projeto executivo mais a listagem de peças do que foi produzido, a dupla de montagem é instruída a iniciar pelos módulos inferiores, de modo que as empresas fornecedoras de tampos, tais como as marmorarias, possam realizar a sua medição e darem continuidade no processo de entrega dos seus produtos para o cliente. Sendo assim, após a montagem da cozinha outros fornecedores continuarão trabalhando no espaço, com a instalação de tampos e bancadas, eletrodomésticos, iluminação embutida e finalização da pintura de teto e paredes, entre outros itens.

Durante a montagem, em algumas empresas do segmento, é possível identificar a figura do supervisor de montagem, profissional que acompanha o processo do começo ao fim, auxilia os montadores no caso de eventuais dúvidas construtivas e providencia ferramentas, por exemplo. Da mesma maneira, este supervisor relaciona para o departamento de assistência técnica uma lista com eventuais peças danificadas e que precisarão ser substituídas. $\mathrm{Na}$ ausência do supervisor de montagem, este trabalho é feito pelo próprio montador, que repassa estas informações diretamente ao departamento responsável.

Figura 47 - Exemplo de listagem de peças (parcial) de uma cozinha

\begin{tabular}{|c|c|c|c|}
\hline Item & Descrição & Dimensão & Referência \\
\hline 1 & Mod sup $800 \times 825 \times 328 \mathrm{~mm}$ & $800 \times 825 \times 328 \mathrm{~mm}$ & DS-1432-0201 \\
\hline 2 & Kit Tip-On Standard novo para dobradica Clip Top s/mola & $1 \times 1 \times 1$ & $2 \mathrm{~A}-2299-00$ \\
\hline 3 & Prat linear $18 \mathrm{~mm}$ - borda 4 lados - Satin Metallic Due Pur & $671 \times 18 \times 600$ & ME3793-215 \\
\hline 5 & Porta $397 \times 658 \mathrm{~mm}$ & $397 \times 656 \times 18$ & ME1021-806 \\
\hline 6 & Kit fer sup fixa çäo metalico alvenaria p'mod 02un & $50 \times 30 \times 30$ & $2 \mathrm{~A}-0288-00$ \\
\hline 7 & Suporte anti empenamento $p^{\prime}$ mod de $800 \propto 18 \mathrm{~mm}$ - branc & $783 \times 15 \times 15$ & U100311-05 \\
\hline 9 & Item es pecial $18 \mathrm{~mm}-4$ bor da & $1838 \times 18 \times 488$ & PRAP001-1638-488-718 \\
\hline 10 & Item es pecial $18 \mathrm{~mm}$ - 4 borda & $1348 \times 18 \times 819$ & PRAP001-1348-819-718 \\
\hline 11 & Item es pecial $18 \mathrm{~mm}$ - 4 bor da & $862 \times 18 \times 352$ & ME00 1-862-352-315 \\
\hline 12 & Item es pecial $18 \mathrm{~mm}-4$ bor da & $1602 \times 18 \times 310$ & ME001-1602-310-315 \\
\hline 13 & Item es pecial $18 \mathrm{~mm} \mathrm{-} 4$ bor da & $1602 \times 18 \times 352$ & MED01-1602-352-315 \\
\hline
\end{tabular}

Fonte: Arquivo do autor 
Nas figuras seguintes pode-se observar a evolução do projeto apresentado na figura 28. Após a etapa de medição (figura 30), projeto executivo (figuras 31 e 32) e vistoria (figura 33), as imagens abaixo apresentam o registro do andamento da montagem, em uma fase que já possibilita a entrada de outros fornecedores para instalação de tampos e eletrodomésticos, por exemplo.

Figuras 48a, b e c - Cozinha modulada em processo de montagem
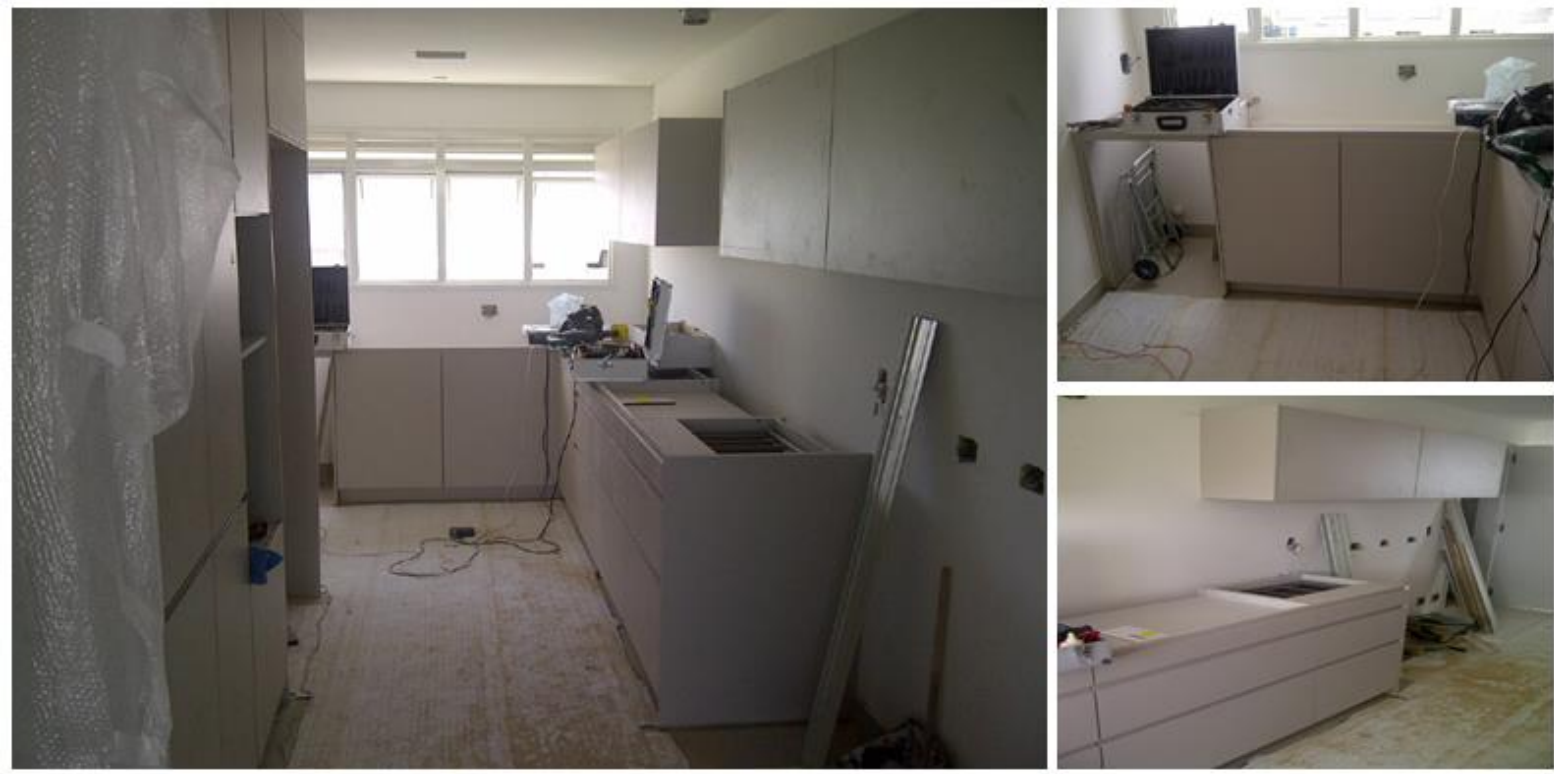

Fonte: Arquivo do autor

Figuras 49a e b - Cozinha modulada com montagem finalizada e com a instalação das bancadas e eletrodomésticos concluídos
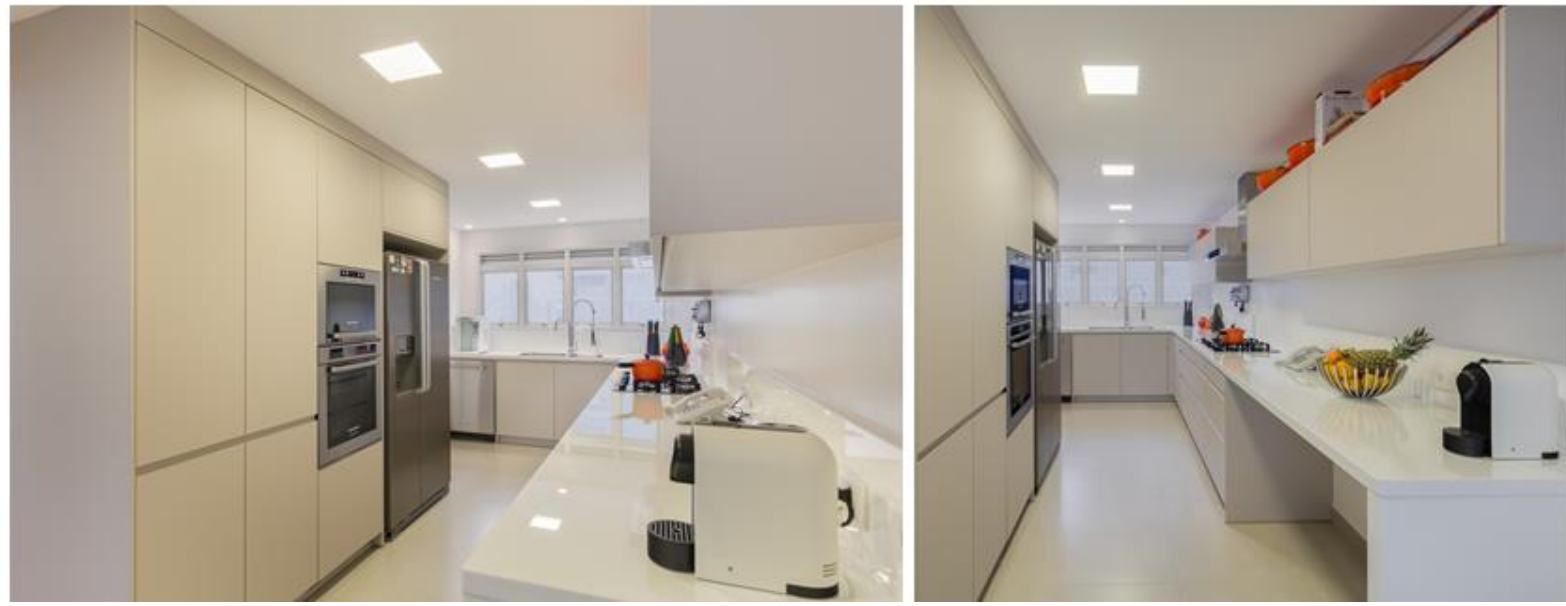

Fonte: Arquivo do autor 


\subsection{Análise dos resultados obtidos na etapa de produção industrial}

Neste subitem são apresentados os resultados obtidos na etapa de produção dos móveis nas indústrias, organizados de acordo com os objetivos específicos definidos no início da investigação e a partir dos dados recorrentes identificados na análise dos dados.

\subsubsection{Circunstâncias geradoras de descarte e tipos de materiais descartados}

Na etapa de pré-produção dos módulos, quando os painéis de madeira reconstituída são enviados dos produtores para as indústrias de móveis é possível identificar uma primeira circunstância no processo que irá gerar descarte pré-consumo de materiais: o transporte dos painéis. Neste transporte, realizado por meio de carretas, os painéis de MDF e MDP são presos nos paletes com cintas, para que evite, assim, o tombamento destes painéis durante o percurso dos centros produtores até as indústrias de móveis. Entretanto, estas cintas machucam as bordas da matéria prima, sendo necessário que todo painel passe por um processo de refilamento das bordas, processo que irá retirar até $30 \mathrm{~mm}$ de cada um dos seus quatro lados.

Figura 50 - Partes retiradas de painéis de MDF $12 \mathrm{~mm}$, resultantes do processo de refilamento das bordas

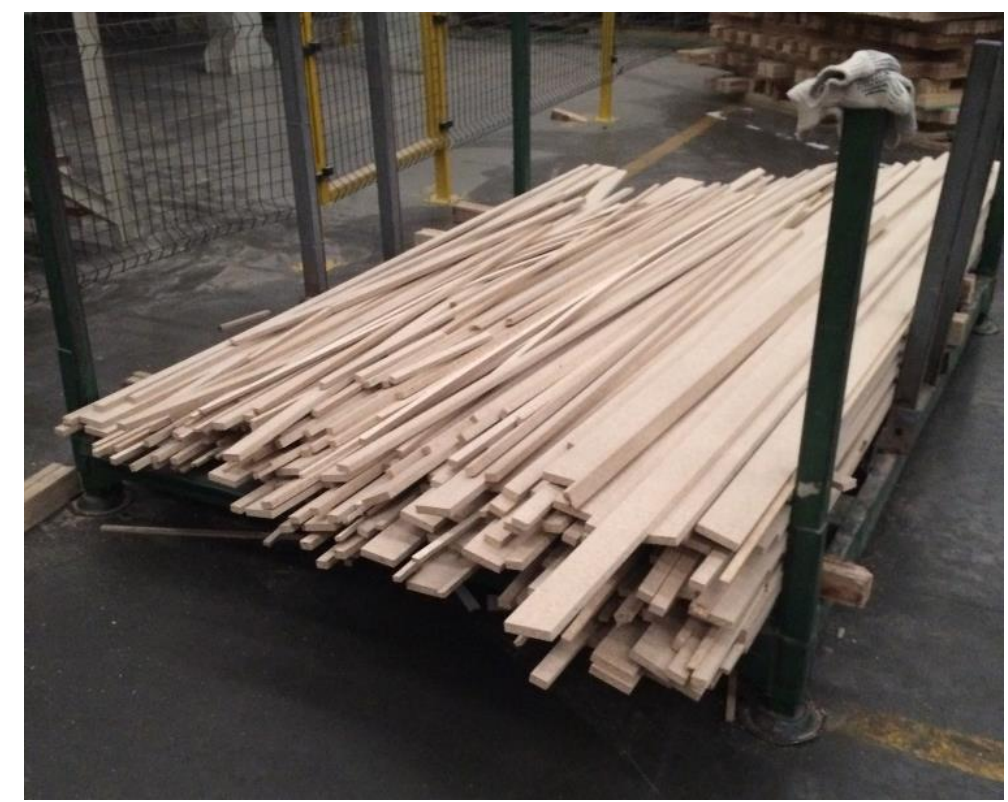

Fonte: Arquivo do autor. 
Da mesma forma, durante a observação nas indústrias, foi possível verificar também que o painel do topo da pilha, que na indústria é chamado de "capa", é mais suscetível a estes danos, pois recebem a pressão concentrada das cintas; o mesmo acontece com o painel que está diretamente apoiado nos paletes, pois recebe o peso de todos os demais que estão por cima.

Figura 51 - Painéis de madeira sendo descarregados em fábrica de móveis. Nota-se que as cintas posicionam-se em variadas partes dos painéis

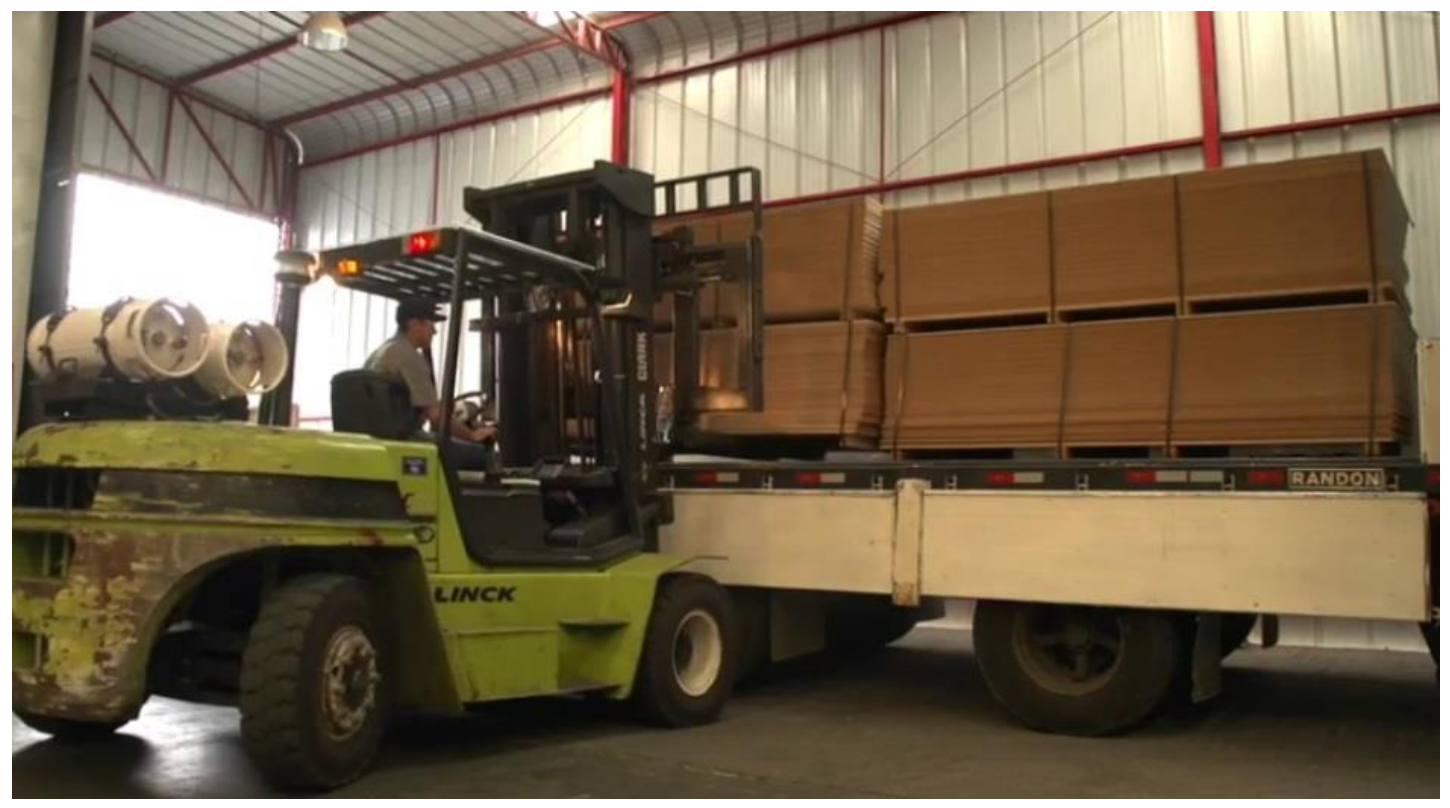

Fonte: http://www.unicasamoveis.com.br/sobre. Acesso em: 02 nov. 2015

Segundo Laercio Brito (2016), engenheiro de produção da indústria de móveis Bartira, o empilhamento máximo é de 15 painéis por palete, para amenizar os danos a estes materiais. Quanto ao volume de materiais, segundo ele, cada carreta comporta 40 paletes e, em média, recebe-se cerca de 33 carretas diárias, 6 dias na semana, para produzir o equivalente a 250 mil peças por dia. A partir do cruzamento destes dados é possível estimar que no caso de uma indústria de móveis de grande porte é consumido o equivalente a 500 mil painéis de madeira reconstituída por mês, naturalmente com espessuras, acabamentos e fornecedores variados, para que desta forma consigam atender a esta demanda na cadeia de suprimentos. É importante destacar que a referência nesta conta é a produção de peças/dia, e cada módulo, considerado como unidade independente, é composto por pelo menos seis peças (base, duas laterais, fundo, teto, porta), conforme ilustrado no capítulo 2.

Entretanto, a partir destes números é possível ter uma dimensão da representatividade do setor moveleiro no cenário industrial brasileiro e do volume de materiais que precisam ser refilados na etapa pré-produção. 
De qualquer maneira, o processo de refilamento prepara a superfície do material para as etapas subsequentes de corte e usinagem e, considerando ainda a etapa pré-produção dos módulos na indústria, o resultado do aproveitamento de material no plano de corte é uma variável importante a ser considerada quanto ao montante de resíduos sólidos gerados na indústria.

Figura 52 - Descarte de MDF e MDP em indústria de móveis, provenientes do excedente de material gerado no plano de corte
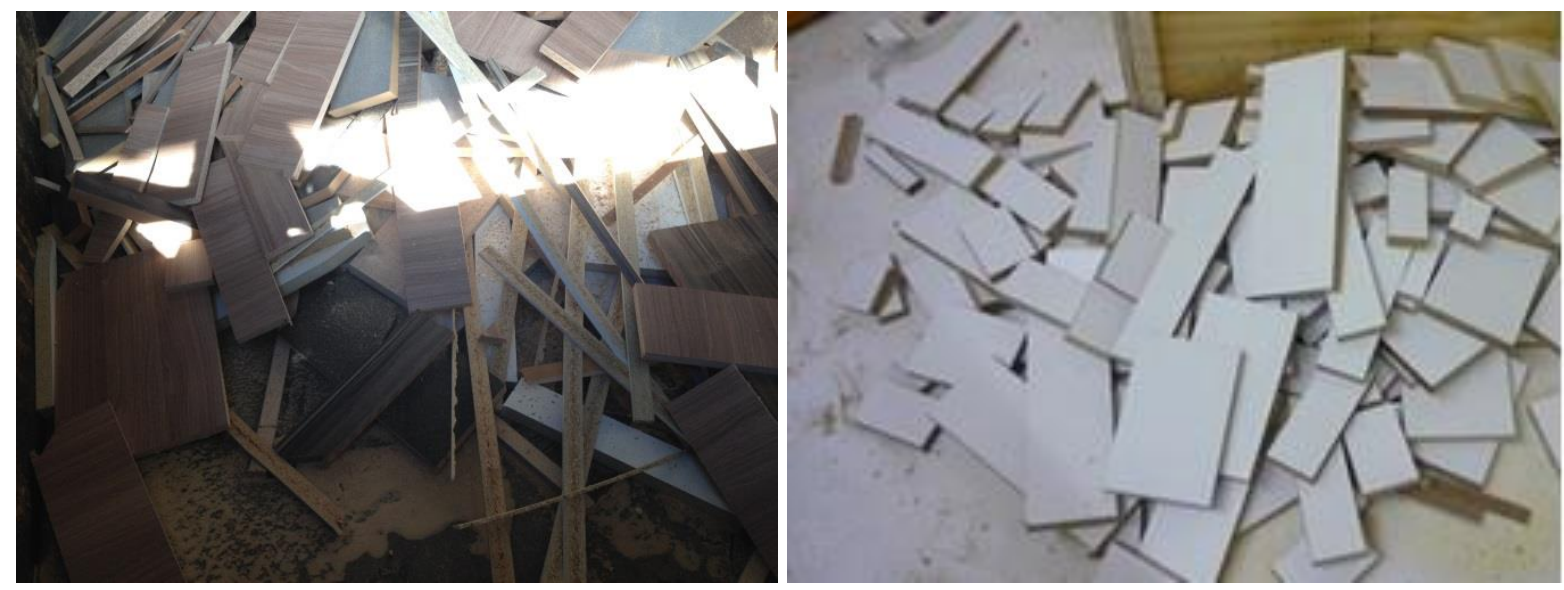

Fonte: Arquivo do autor.

Quando perguntado aos entrevistados sobre o percentual de madeira descartado neste processo, os dados parecem imprecisos, variando de 3 a 7\%. Marcel Baralti (2016), diretor industrial no setor moveleiro, acredita que este percentual chegue a $12 \%$ considerando somente o descarte do MDF e MDP, que é ocasionado, principalmente, pela personalização dos projetos e destaca que "cada projeto é único e que os pedidos entram em produção prioritariamente de acordo com os prazos acordados com os clientes e não considerando os lotes de materiais disponíveis na indústria". Joerly Santos (2016) concorda quanto à personalização e acrescenta que a mensuração de percentual de material descartado, assim como a sua classificação e identificação talvez só seja possível em indústria de móveis seriados, que mantém a mesma produção por dois a três anos, diferente das indústrias de móveis planejados e sob medida, em que o produto e o projeto possuem muitas variáveis. Ou seja, possivelmente por esta razão os dados informados são estimados.

De qualquer forma, um bom índice de aproveitamento é quando o plano de corte indica um percentual de uso do material de pelo menos 90\%. Felipe Ferreira (2015), diretor de indústria de móveis, aponta que em alguns casos o percentual de aproveitamento do painel de madeira chega a apenas $60 \%$, por conta da baixa quantidade que será usado de um 
determinado revestimento no projeto. Segundo ele, o material excedente não utilizado em determinado lote de produção por vezes é separado e armazenado por um tempo dentro da indústria, para tentativa de uso em outros projetos, mas que muitas vezes pode não acontecer. Além disto, Baralti (2016) destaca como representativo o descarte dos revestimentos estampados e madeirados, que por prioridade estética da continuidade dos veios da madeira, o aproveitamento do painel no plano de corte respeitará o sentido da estampa.

Na figura abaixo é possível entender melhor a relação entre o uso dos materiais no projeto da cozinha e a propensão de descarte de materiais na indústria: em maior quantidade foi utilizado um padrão de cor liso, para o revestimento dos tamponamentos e para as frentes dos módulos. Um padrão madeirado em menor quantidade foi utilizado para criar uma área de refeições e outro padrão de revestimento mais escuro foi utilizado apenas nos painéis e prateleiras decorativas, sobre a área da pia. Da mesma forma, é possível observar que o sentido da estampa, no revestimento madeirado utilizado, segue uma mesma direção, o que talvez tenha gerado um percentual significativo de não aproveitamento do material.

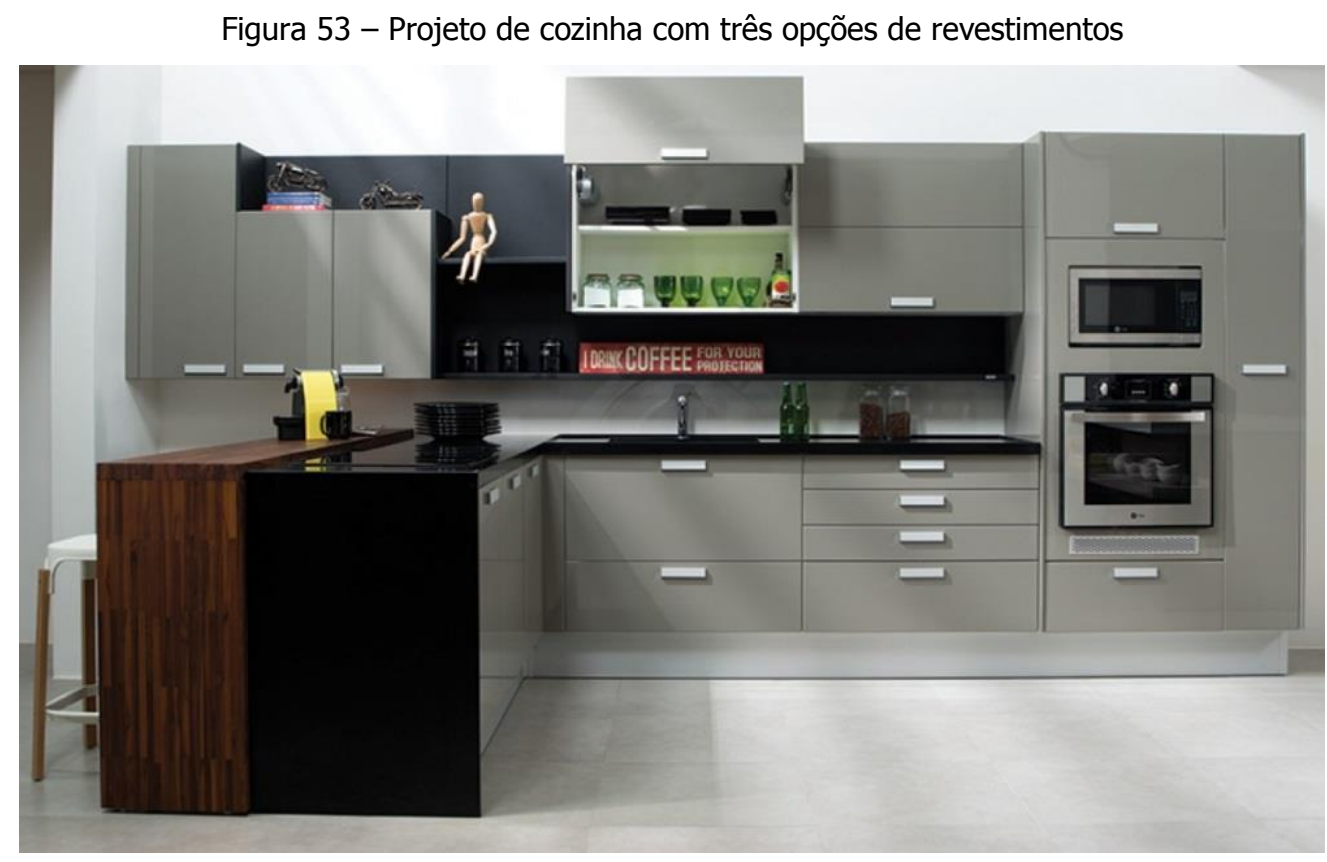

Fonte: http://www.favomoveis.com.br/novo/visualiza_produto.php?c=307\&l=5. Acesso em 01 fev.2017.

Baralti (2016) e Santos (2016) também apontam um cenário diferente em relação ao aproveitamento e descarte de materiais a partir de 2010, com a implantação da PNRS, que definiu que o gerador de resíduos sólidos é o responsável pela destinação do material excedente na produção. Possivelmente por esta razão, os profissionais destacam o 
surgimento de empresas especializadas no serviço de corte dos painéis, como uma alternativa para corte dos painéis fora das indústrias de móveis. Cabe destacar aqui que este serviço de corte de painéis (e de plano de corte) já é oferecido também em lojas de materiais e insumos para marcenarias, tais como Leo Madeiras e Leroy Merlin, em que pode se perceber que o material excedente na etapa de corte é vendido aos clientes, reduzindo o que possivelmente iria para o lixo.

Figuras 54a e b: Alternativa de venda de resíduos sólidos de madeira reconstituída
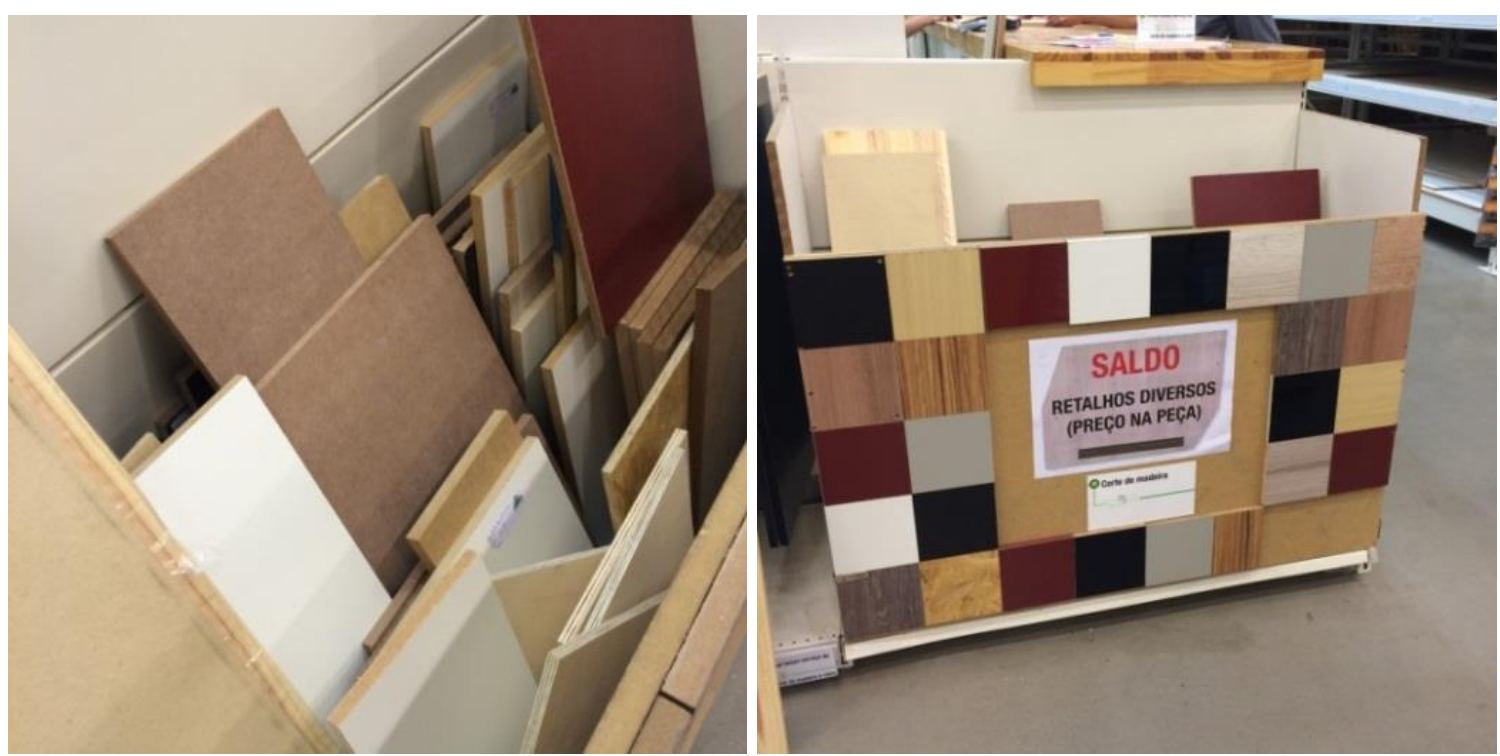

Fonte: Arquivo do autor. Foto tirada em home center.

No contexto industrial, Agnaldo de Castro (2017), gerente de produção industrial, destaca que antes do material excedente no plano de corte ser descartado, são feitas tentativas de uso deste material dentro do ciclo produtivo, principalmente no caso do aproveitamento de peças grandes. Entretanto, como o volume de produção na indústria diariamente é alto, como consequência, este material excedente consome um espaço considerável e não há local dentro da indústria para armazenagem destas peças por um período muito longo. Segundo ele, em último caso será feito o seu descarte, ocasionando na geração de resíduos sólidos industriais.

Quanto aos materiais, o plano de corte é realizado especialmente nos produtos à base de madeira reconstituída, considerando os painéis de MDF e do MDP, que corresponde a aproximadamente $80 \%$ do material na produção dos móveis para cozinha. A composição percentual de outros materiais fica a cargo das ferragens e componentes para os módulos, das tintas utilizadas no processo de pintura e do revestimento de outras superfícies como os 
vidros e espelhos, que são enviados pelos fornecedores prontos, cortados e acabados, para as indústrias de móveis. Ainda considerando a pré-produção dos produtos, outra característica da geração de resíduos sólidos, resultante do plano de corte, são as partes do material excedente que forem menores que $60 \mathrm{~mm}$ de largura. Tais peças são descartadas automaticamente, pois não entram nas máquinas de corte industriais.

Por meio de observação nas indústrias, foi possível identificar uma característica comum entre as etapas de refilamento (pré-produção), corte dos painéis e usinagem (produção) dos painéis de madeira reconstituída, que geram outro tipo de resíduos sólidos industriais, que é o pó de serra. Esta serragem, como também é chamada, é ocasionada pela passagem das lâminas da serra em cada fase do painel, o que também reduz a medida final do painel em cerca de 3 a $4 \mathrm{~mm}$, por cada corte executado. Este pó de serra é aspirado automaticamente das máquinas industriais (ver figura 39) e separado em tambores, o que contribui para a limpeza geral da indústria, para a separação adequada dos resíduos sólidos e para que este resíduo não ocasione danos às máquinas ou processos, como os de pintura, por exemplo.

Assim como a retirada de $30 \mathrm{~mm}$ referente ao processo de refilamento das bordas, o desconto de corte da serra deve ser considerado como resultante na medida final útil do painel de madeira, para o projeto de produtos.

Além do descarte de materiais relacionado aos processos de corte e usinagem dos painéis de madeira reconstituída, Esther Schattan (2015), diretora de indústria de móveis, identifica a ocorrência de erros durante o processo de produção, por parte das máquinas e dos técnicos de produção, que também ocasionam descarte de materiais. No caso de incidentes com superfícies de vidro e espelho, por exemplo, as peças são inteiramente descartadas: quanto ao espelho, aponta o "problema da usinagem, que exige equipamentos próprios, banhos, e se a gente simplesmente cortar para usar em outra porta ele pode oxidar na casa do cliente". Quanto ao vidro, também não é possível o aproveitamento de peças quebradas dentro das indústrias de móveis, "pois isto implica na aquisição de máquinas e processos especiais, o que é difícil para a indústria de móveis".

Agnaldo de Castro (2017) destaca que uma boa máquina que faça o corte, lapidação e polimento do vidro e que seja adequada ao segmento de móveis modulados é um investimento em torno de $\mathrm{R} \$ 1$ milhão. Ainda que em menor proporção, o descarte de outros tipos de superfícies como o espelho e o vidro representa, assim, um problema para as indústrias de móveis, pois não permitem ajustes ou eventuais práticas de reaproveitamento 
dentro do ciclo produtivo, já que o processo de produção destas superfícies é realizado por empresas especializadas e as indústrias de móveis não possuem tais equipamentos ou knowhow.

De qualquer forma, eventuais erros que possam ter ocorrido nos produtos são descobertos ao final do processo de produção, em que é feito o controle de qualidade dos produtos, para que as peças possam ser embaladas para a expedição. Nesta etapa, verificam-se as quinas e bordas das peças, que podem ter sido eventualmente batidas durante o processo de produção e acabamentos da superfície. No caso de peças reprovadas e que não poderão ser ajustadas, são isoladas para que seja feito o seu descarte. Baralti (2016) afirma que na maior parte dos casos o retorno da peça danificada ao ciclo produtivo não é vantajoso, pois sai do processo automatizado, o que vai exigir que um técnico da produção monitore o seu reaproveitamento, tanto na redução da peça, para inclusão em outro projeto, quanto na correção da parte danificada, e o tempo e a mão de obra são fatores importantes na indústria, no que se refere aos custos de produção. Além disto, segundo ele, o custo de um painel inteiro de MDF é de aproximadamente $\mathrm{R} \$ 100$; se for somado o custo de hora de trabalho do operador da máquina, consumo de energia elétrica e o custo individual da matéria prima da parte pequena descartada, o aproveitamento na indústria não faz sentido. Ou seja, é mais econômico descartar a peça danificada do que tentar reutilizar produtos não aprovados no controle de qualidade. Quanto ao aproveitamento de peças danificadas dentro da indústria, entretanto, há exceção no caso de peças com a superfície pintada, que retornam à câmera de pintura para que o processo seja refeito.

Nestas indústrias que possuem o processo de pintura das superfícies, para não haver interferência de cor na superfície do material entre uma seção de pintura e outra é feito a limpeza na cabine, por meio de um processo químico que separa a borra do solvente. $\mathrm{A}$ borra, caracterizada como rejeito, é separada em tonéis para a sua destinação adequada, conforme diretrizes estabelecidos na PNRS. Sucessivamente, o solvente é reutilizado nos processos de pintura subsequentes para nova limpeza da cabine e diluição de novo lote de tinta.

Além das tintas, também pode ser observado outros tipos de materiais comumente descartados nas indústrias de móveis para cozinha moduladas, que apesar de representarem baixa percentagem de uso quando comparadas ao MDF e ao MDP, devem ser considerados e identificados em que fase da produção industrial isto ocorre. 
Um exemplo destes materiais são os suportes das bobinas de fita de borda, produto à base de papel, com $17 \mathrm{~cm}$ de diâmetro. Cada suporte contém uma bobina com a fita de borda em PVC, em geral com 200 metros de comprimento e com larguras que seguem o padrão das espessuras dos painéis de madeira e são inseridas dentro das máquinas coladeiras de borda, para colagem da borda nos painéis, de modo automático. Da mesma forma, estas bobinas não são aproveitadas em sua totalidade, o que gera alguns centímetros de fita de borda de PVC de material que será descartado por bobina.

Figura 55a: Detalhe das bobinas de fita de borda em PVC, em cores variadas

Figuras 55b e 55c: Descarte dos suportes de papel e do final das bobinas de fita de borda em PVC
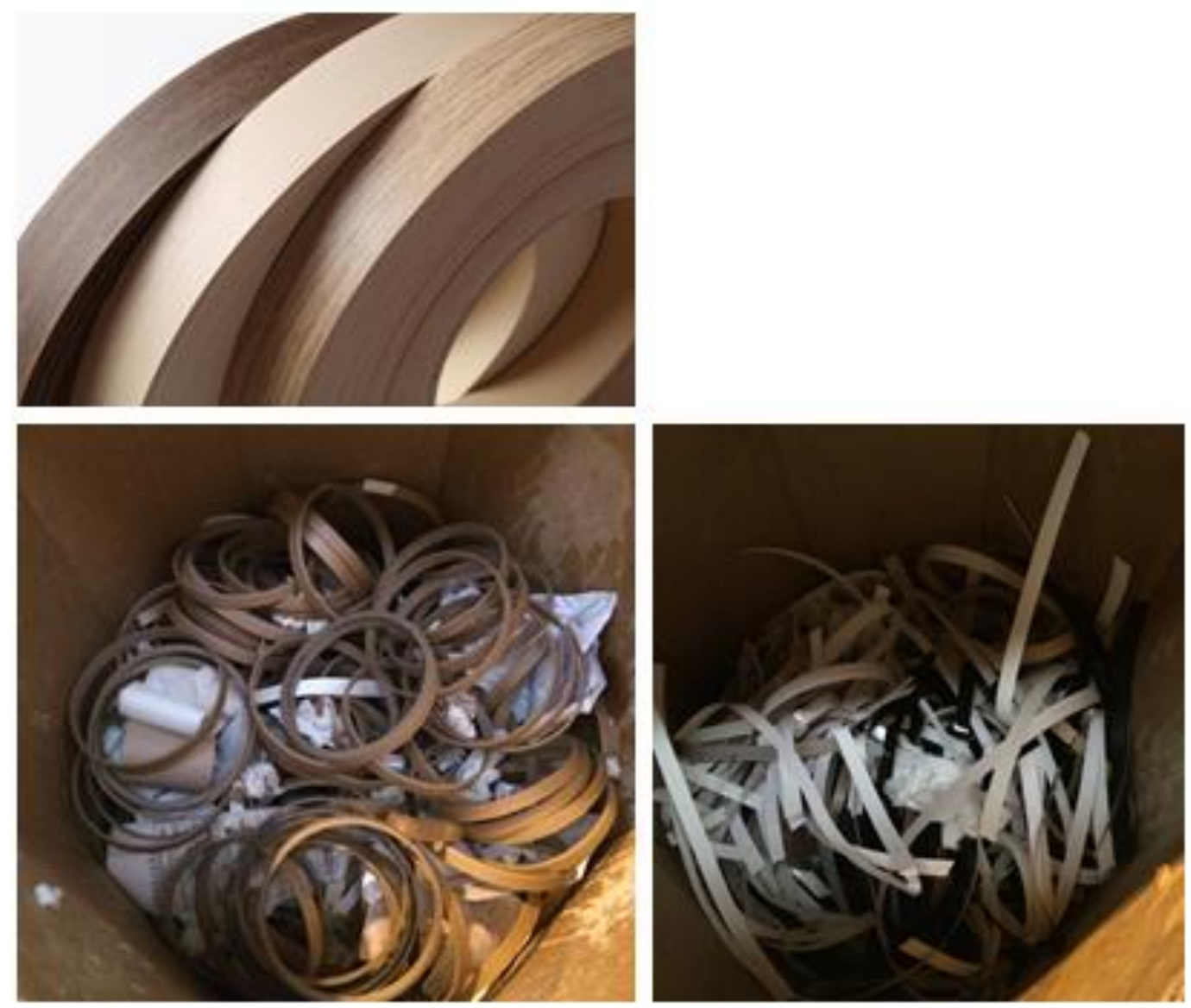

Fonte: http://madepar.com.br/Produtos/29-fitas-de-borda-e-bobinas-pvc-. Acesso em: 07 fev.2017 Fonte: Arquivo do autor.

Os materiais metálicos, produzidos por empresas especializadas e vendidos por quilo e em barras para as indústrias de móveis é outro tipo de material que gera descarte. Entre seus derivados, encontram-se o aço e os perfis de alumínio, utilizados principalmente como puxadores nos módulos. A ocorrência de descarte deve-se ao fato do ajuste que precisa ser feito, entre as medidas destes perfis metálicos e as medidas dos módulos de cozinha, seja na largura ou altura. 
Figura 56: Puxador perfil metálico embutido em módulo de cozinha
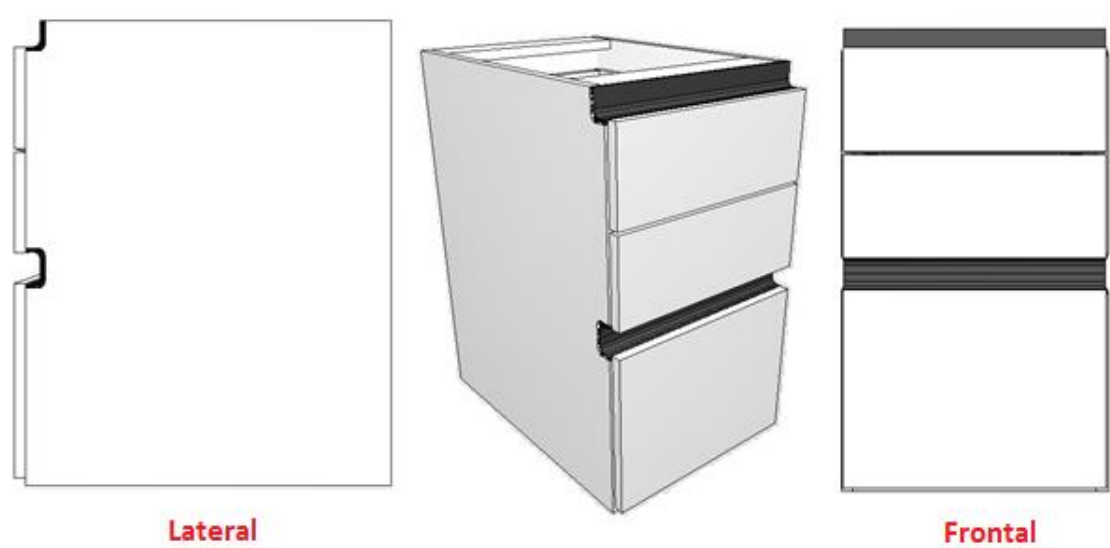

Fonte: http://kb.promob.com/support/pt-br/Paginas/KB1050.aspx. Acesso em: 15.jan.2017.

Nas indústrias que possuem o processo de prensa e colagem do laminado uma parte da folha do laminado não é aproveitada, e a sua classificação e volume seguem o mesmo padrão sazonal da geração dos resíduos sólidos provenientes do descarte de outros materiais em outras etapas da produção, o que torna inviável a sua classificação. Entretanto, sabe-se que as medidas destas folhas de laminado variam em 1250 × 3000 mm (MADEPAR, 2017), contra a medida dos painéis, de 1840 x 2750 mm (DURATEX, 2017).

E por fim, mas não menos importante, precisa ser abordado o descarte das embalagens dos produtos que chegam dos fornecedores de insumos para as indústrias de móveis. Sejam as embalagens de papelão, polietileno ou de poliestireno (isopor), são embalagens que armazenam e protegem os componentes no transporte dos fabricantes até às indústrias de móveis. Ainda que enquanto processo, o descarte das embalagens não esteja diretamente ligado à produção dos produtos, enquanto material o descarte das embalagens é realizado dentro das indústrias de móveis, somando-se assim ao montante de descarte de material que é gerado no processo.

Também é importante mencionar que a relação de materiais que aqui está sendo apresentada se refere aos tipos mais recorrentes de resíduos sólidos gerados e que puderam ser identificados durante a produção industrial dos móveis, não sendo considerado nesta análise o descarte de materiais pontuais ou não relacionados ao contexto investigado. 
Somado aos outros tipos de resíduos sólidos gerados no processo, de maneira geral é possível classificar o descarte por tipos de materiais:

- $\quad$ Madeira reconstituída, na variação MDF e MDP

\section{Serragem}

- Vidro

- $\quad$ Espelho

- $\quad$ Papel (rolo das bobinas de fita de borda)

Papelão (embalagens)

- $\quad$ Tintas $^{9}$

- $\quad$ Policloreto de vinila (PVC, utilizado nas fitas de borda)

Poliestireno (isopor, utilizado em embalagens)

Polietileno de baixa densidade (PEBD, utilizado em embalagens)

- $\quad$ Ferrosos (aço) e não ferrosos (perfis de alumínio)

Da mesma forma, as ocorrências de seu descarte, no processo pré-produção e produção acontecem baseado nas seguintes circunstâncias:

- Transporte dos painéis, que gera o processo de refilamento das bordas;

- Plano de corte e a não utilização do material excedente;

- Corte e usinagem das partes do módulo, gerando pó de serra;

- Limites técnicos das máquinas, como o bocal da seccionada, que não aceita peças menores que $60 \mathrm{~mm}$ e o final das bobinas da fita de borda, por exemplo;

- Revestimentos estampados ou aqueles usados em baixa quantidade nos projetos;

- Controle de qualidade, na limpeza das câmeras de pintura e no descarte de partes em não conformidade com os padrões dos produtos da indústria;

- Erros e incidentes na produção, por fatores humanos ou ocasionados pelas máquinas, que implicam na redução da peça danificada ou no seu descarte;

- Ajuste de componentes, como por ex. o ajuste dos perfis metálicos;

- (des) embalagem de insumos industriais;

\footnotetext{
${ }^{9}$ Como abordado anteriormente, a borra da tinha caracteriza-se como rejeito e não como resíduo sólido industrial.
} 


\subsubsection{Destinação dos materiais descartados}

Quanto à destinação dos resíduos sólidos gerados no processo de produção dos módulos, baseado nas entrevistas e na observação em campo, pode-se perceber um cenário muito similar entre as indústrias, relacionado ao tratamento do descarte de materiais e nas tentativas de aproveitamento dos materiais dentro do ciclo produtivo. Assim, de maneira geral, a destinação pode ser dividida em grupos, em função da classificação dos materiais.

Os resíduos sólidos provenientes do descarte dos polímeros, assim como o papel e o papelão, por exemplo, representam um volume relativamente baixo quando comparado ao descarte da madeira reconstituída e, por esta razão, o descarte destes materiais aparece na maior parte das vezes separado do descarte de outros produtos para fins de reciclagem e em algumas indústrias estes resíduos são vendidos. Da mesma forma, os resíduos sólidos de pó de serra, gerados nas etapas de corte e usinagem dos painéis de madeira, são vendidos para empresas específicas que o utilizam para combustão.

Em outro grupo pode ser identificado os rejeitos provenientes do descarte da borra das tintas, no processo de limpeza das câmeras de pintura. Estes rejeitos são separados em tonéis apropriados para o seu descarte para serem coletados nas indústrias por empresas especializadas, para tratamento em conformidade com as legislações ambientais vigentes.

Em um processo de logística reversa, encontram-se os resíduos sólidos provenientes do metal, que também são separados de outros resíduos industriais. Em geral foi identificado dois tipos de destinação: os metais ferrosos são vendidos para empresas de compra de sucata. Os metais não ferrosos, como o alumínio, as sobras são armazenadas e retornam para os fornecedores, que em alguns casos o utilizam como crédito em novos pedidos.

Os resíduos sólidos gerados de outros materiais, como o vidro, o espelho e a madeira reconstituída, são descartados juntos e ficam armazenados em caçambas para serem coletados por empresas certificadas pelo transporte e gestão dos resíduos sólidos. Neste processo, segundo Márcia Trindade (2016) da empresa Ambitrans, tem-se pelo menos três responsáveis: o gerador, o transportador e o receptor. O gerador, conforme definido pela PNRS é a indústria, que é quem define o tipo de receptor destes resíduos. O transportador é o responsável por buscar estas caçambas na indústria e encaminhá-las até o receptor, que irá tratar estes resíduos conforme o seu funcionamento. 
No caso dos resíduos da madeira, por exemplo, foi apontado que este material segue para zonas de tratamento que o transformam em cavacos, para gerar biomassa (combustível).

Naturalmente a abordagem de questões pertinentes a desenvolvimento de produtos industriais e sustentabilidade inevitavelmente direciona o discurso para políticas, normas e leis ambientais. Logo, pode haver certa resistência por parte de profissionais em participação de pesquisas desta natureza. Muitos contatos foram feitos com os receptores, para poder verificar o que de fato está sendo feito com estes resíduos e como se dá o processamento da biomassa. Entretanto, nenhum deles demonstrou interesse ou não quiseram formalizar os contatos realizados. Em conversa informal por telefone com um engenheiro ambiental, que desde 2008 trabalha com gerenciamento de resíduos sólidos para construção civil, informou confidencialmente que a PNRS aponta a obrigação do destino dos resíduos, mas segundo ele "falta fiscalização nos receptores, o que abre muita brecha para a informalidade", o que pode vir a se tornar um problema, pois na composição química destes materiais há produtos perigosos, e se no momento do seu descarte não forem tomadas as medidas adequadas quanto a sua destinação, pode acarretar em problemas ambientais e interferir na saúde das pessoas.

Da mesma forma, nas indústrias, os resíduos sólidos de madeira reconstituída, tais como o MDF e o MDP, representam boa parte da atenção dos empresários, não somente para que a indústria esteja em conformidade com os objetivos estabelecidos na PNRS, mas pelo volume considerável e os custos que o descarte deste material representa.

Segundo informado pelos empresários, estas caçambas ficam aproximadamente duas semanas dentro das indústrias, intervalo que varia conforme o volume da produção. Neste período, este material está sujeito à ação do tempo, com incidência de sol e sob o risco de chuva, o que muitas vezes deteriora o material antes mesmo de sair da indústria. Outra informação relatada é que dependendo do tempo que demorar a coleta, a indústria paga pelo aluguel destas caçambas, além de uma taxa variável baseada em seu peso e do custo com o imposto de circulação de mercadorias (ICMS). Por estas e outras razões, no que diz respeito ao tratamento do descarte pré-consumo dentro da indústria, todos os profissionais consultados e entrevistados relataram já terem participado de tentativas de aproveitamento deste material, entretanto, muitas delas pontuais e não bem sucedidas por diversos fatores. 
Felipe Ferreira (2015), diretor de indústria de móveis, destaca a experiência que teve na parceria com o Grupo de apoio às crianças com câncer (GRAACC) e com a Associação brasileira dos fabricantes de brinquedos (Abrinq), em que tentou fabricar brinquedos a partir do descarte de madeira. Como as instituições parceiras não possuíam o ferramental e a técnica para produção dos brinquedos, decidiu criar uma oficina e produzir os brinquedos dentro da sua indústria com os funcionários, durante o expediente de trabalho. Segundo ele, o projeto teve que ser interrompido pela exigência de certificação com o Inmetro e por uma denúncia anônima feita ao sindicato, que apontava desvio de função. Ele acredita que as ONG's sejam um bom caminho quanto ao aproveitamento de materiais, porém, para isto é necessário criar um plano de negócios, que faça a gestão de todo este processo. 0 diretor informa que atualmente adota o que está estabelecido na Lei 12.305/10: os resíduos sólidos industriais são descartados na caçamba e as empresas de coleta o recolhem.

Esther Schattan (2015) diretora de empresa de móveis Ornare informa que desde a metade da década de 1990 vem elaborando alternativas quanto ao reaproveitamento dos resíduos sólidos industriais, em parcerias com instituições próximas à sua indústria. Destaca que uma das primeiras ações que teve com uma ONG, chamada Sítio do Pinheirinho, foi na criação de brindes para clientes, tais como suporte de bloco de notas, porta lápis e caixinhas, criados a partir de sobras de madeira da produção, projeto interrompido porque a espessura do material utilizado para este fim deixou de ser fornecida. A diretora destaca que as ONG's têm as suas limitações, de pessoal e recursos, o que naturalmente faz com que boa parte destes projetos sejam descontinuados. Recentemente, a empresária tem investido na parceria com universidades e estudantes de design, com a proposta da criação de produtos e tipologia de objetos a partir de resíduos sólidos industriais.

Eduardo Bellizia (2015), gerente de desenvolvimento responsável pelos produtos da empresa, destaca as tentativas que teve há alguns anos na criação de uma linha de produtos desenvolvidos exclusivamente a partir dos resíduos sólidos. 0 projeto não teve prosseguimento porque, entre várias razões, seria necessário montar uma oficina dentro da indústria, pois a criação destes produtos implicaria em processos de produção artesanais, o que é uma lógica contrária à produção industrial, de produtos em larga escala. Da mesma forma, quando foram levantados os números referentes à precificação, percebeu o alto custo final destes produtos, o que inviabilizaria a sua comercialização, além da não regularidade no fornecimento da matéria prima, uma vez que o descarte não é padronizado. 
Laércio Brito (2016), engenheiro de produção da indústria de móveis Bartira informa que uma alternativa encontrada na indústria é a venda destes resíduos de madeira reconstituída para um produtor menor, que produz com este material, entre outros produtos, tábuas de passar roupas, por exemplo.

Ane Dallago (2015), designer do grupo industrial Unicasa, aponta estratégia similar de destinação do descarte, em que todos os resíduos sólidos industriais de madeira gerado na produção são vendidos para fornecedores da região de Bento Gonçalves, no estado do Rio Grande do Sul, tanto os resíduos sólidos provenientes do excedente de produção quanto as peças que não foram aprovadas no controle de qualidade. Ela acrescenta informando que "foram feitas tentativas de aproveitar este descarte dentro da fábrica, mas para isto seria necessário pelo menos dois funcionários, para separação e classificação, o que tornaria o processo lento e caro", observação também apontada por outros profissionais ligados à indústria, pois alegam que determinadas práticas de aproveitamento dentro das fábricas configura processos de produção artesanais, o que vai contra a lógica industrial de produção de itens em série, principalmente com a automação industrial cada vez mais presente, no cenário contemporâneo.

Da mesma forma, segundo o relato dos empresários, eles reconhecem que os aspectos ecológicos de um produto e a sustentabilidade são tópicos muito abordados na relação com os investidores e questionados pelos clientes, o que certamente pode contribuir para que as empresas tenham um olhar cada vez mais atento a estas questões.

\subsection{Análise dos resultados obtidos na etapa de projeto}

Conforme apresentado na figura 26, as etapas de projeto no segmento de móveis modulados para cozinhas compreendem ao menos três momentos: o projeto do produto, desenvolvido nas indústrias pela equipe de design e desenvolvimento; o projeto inicial que é desenvolvido pelos vendedores projetistas nas lojas, para fins de orçamento e venda dos produtos, e o projeto executivo, etapa posterior à venda dos produtos, que é utilizado como ferramenta de compatibilização entre o que foi vendido e as medidas do imóvel. Este é o projeto executivo o qual se refere a coleta de dados deste subcapítulo, realizado pelo projetista técnico e que é um elo importante entre as etapas comercial, de produção e de montagem. 


\subsubsection{Circunstâncias geradoras de descarte de materiais}

Um primeiro dado a ser destacado e que foi relatado por todos os projetistas entrevistados, mesmo os mais experientes, é que eles não acompanham a montagem, alguns deles nunca visitaram uma instalação e desta forma não possuem dados muito concretos quanto ao processo construtivo da montagem de móveis modulados e as ferramentas utilizadas pelos montadores, assim como as limitações técnicas de alguns produtos. Isto se torna particularmente visível nos resultados obtidos com os montadores, que reclamaram que em projetos mais elaborados faltam informações técnicas especificas para a montagem, resultando que, em muitas vezes, os montadores não sabem como proceder, partindo para decisões e soluções próprias, que muitas vezes não são as melhores, o que pode ocasionar a troca de itens. Da mesma forma, muitas destas decisões tomadas no momento da instalação pelo montador não são registradas e permanecem desconhecidas pelo projetista que, consequentemente, acaba por não incorporá-las em novos projetos, o que provavelmente pode ocasionar novos erros e a geração de mais material de descarte.

Segundo relato dos projetistas, uma das etapas mais difíceis no desenvolvimento do projeto executivo não é somente a compatibilização de medidas entre o projeto inicial vendido e o levantamento métrico, mas a compatibilização de medidas entre os eletrodomésticos, as instalações, sejam as elétricas, hidráulicas e de gás, existente nas cozinhas e o tamanho dos módulos. Eles informaram que os fabricantes (tais como Brastemp, Electrolux, Lofra) não possuem um padrão de medidas para estas instalações, o que aumenta a probabilidade de erros. Eles afirmam que sempre consultam os manuais a cada projeto que iniciam, entretanto, identificaram muitos casos de medidas divergentes entre o que está informando no manual e a medida real do equipamento constatado na hora da instalação, o que ocasiona abertura de assistência técnica para a substituição de algumas peças da cozinha. Também quanto aos manuais dos eletrodomésticos, redobram a atenção no caso de eletrodomésticos embutidos e destacam que os principais fabricantes não detalham os nichos de embutimento adequadamente. No caso dos fornos embutidos (que na etapa de montagem foi identificado como um problema recorrente para os montadores) os projetistas devem indicar em projeto o vão interno da caixa do módulo, vão que precisa ser compatível com a dimensão da carcaça do forno. Da mesma forma, no manual do fabricante dever ser informado o tamanho da frente deste forno, para a indicação em projeto da abertura da "máscara", que é o acabamento necessário em volta deste forno. 
Figura 57: Exemplo de detalhe de nicho de embutimento de forno, extraído do manual de fabricante de eletrodoméstico

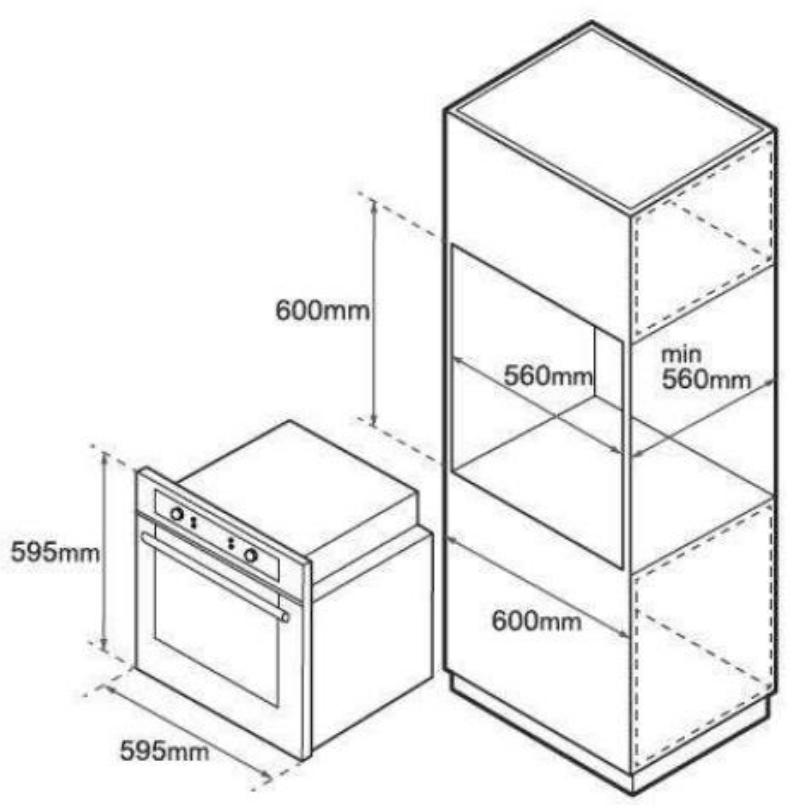

Fonte: http://www.lofra.com.br//files/brochuras/Forno\%20LARGE\%20TO72\%20EXDB2\%20. Acesso em: 07 fev.2017

Como estas medidas são muito precisas, com poucos milímetros de diferença, no caso de divergências de informações em projeto, novas peças precisarão ser produzidas, pois os montadores não possuem ferramentas na montagem que possibilitem tamanha precisão para ajuste. Além destas variáveis, para cada eletrodoméstico tem que ser previsto e indicado em projeto os pontos elétricos, hidráulicos e de gás e os projetistas alegam que muitas vezes faltam nos manuais dos fabricantes a indicação dos locais adequados a tais instalações.

Durante a compatibilização de projeto, um aspecto recorrente entre os projetistas refere-se a algumas peças que são propositalmente solicitadas maiores para a indústria para que os montadores consigam fazer os devidos ajustes em casos das paredes estarem fora do esquadro, por exemplo. Dentre tais peças, cabe destacar as de acabamento, tais como os arremates superiores, laterais ou de canto e os tamponamentos. No caso dos arremates laterais e de canto são enviados $50 \mathrm{~mm}$ maiores na largura e no caso dos arremates superiores são enviados $50 \mathrm{~mm}$ maior na largura e na altura. No caso dos tamponamentos, são enviados $50 \mathrm{~mm}$ maior na profundidade e $100 \mathrm{~mm}$ na largura. Mesmo sendo uma medida de precaução, com o propósito de evitar a troca de peças, o ajuste destas peças nos 
locais de montagens gera descarte de material, em que pôde ser identificado desde pequenos retalhos de madeira, até geração de pó de serra durante o corte dos produtos.

Figura 58: Detalhe de cozinha modulada com a indicação das peças, tais como tamponamentos e arremates, que são enviados maiores na altura e largura, para ajuste nos locais de montagem

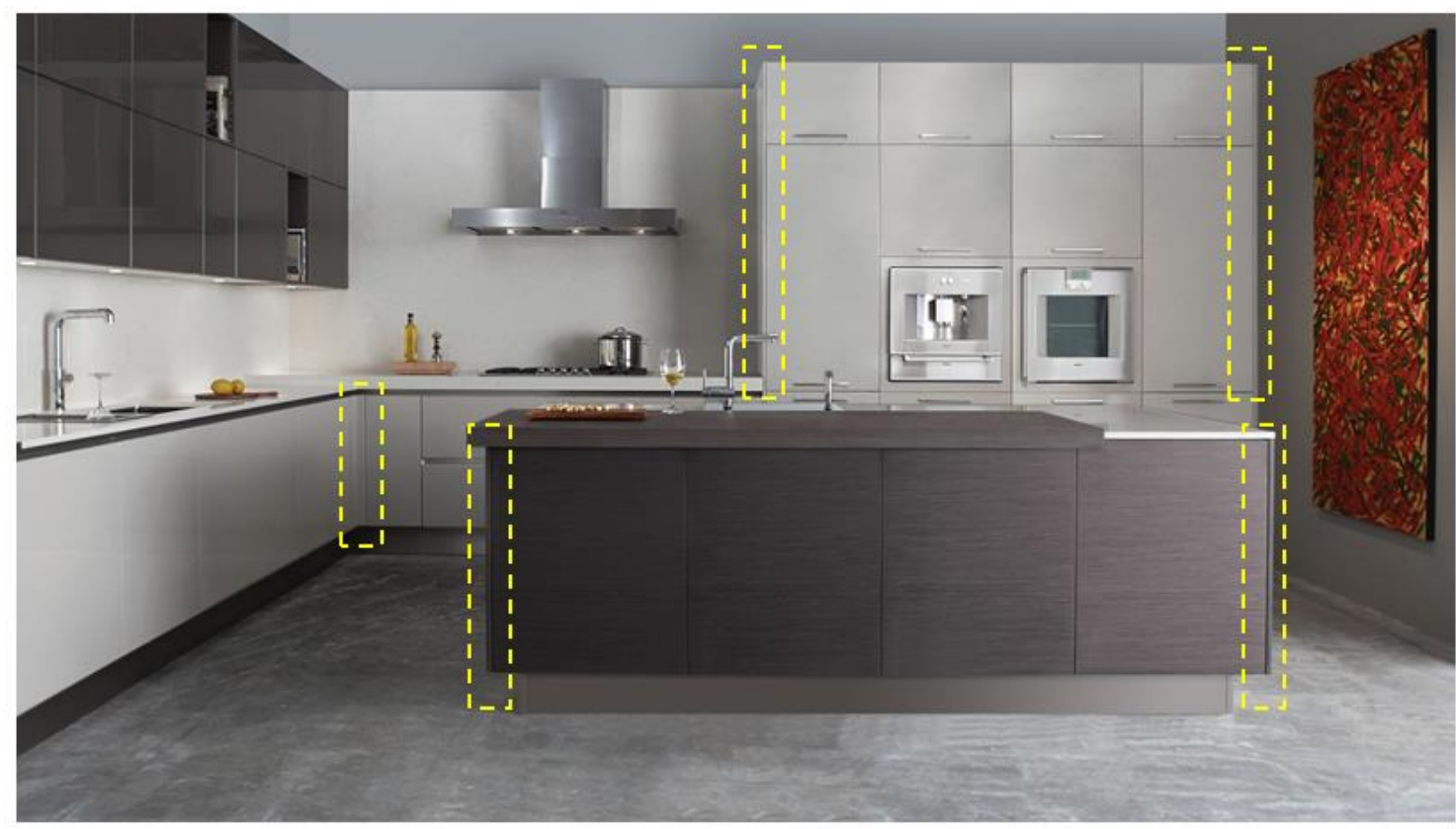

Fonte: http://www.florense.com.br/pt/produtos/cozinhas/tech-e-moderna/14024/\#!gallery/6/. Acesso em: 07 fev.2017.Detalhes inseridos na imagem pelo autor da Dissertação.

Outra crítica recorrente dos projetistas refere-se às alterações no projeto, também chamadas de revisões, que em muitos casos surgem por fatores que influenciam diretamente o projeto executivo e que deveriam ter sido resolvidos na etapa comercial, como fogões que na etapa comercial são previstos na modulação da parede, mas que no projeto executivo este mesmo eletrodoméstico é transposto para uma configuração em ilha - este tipo de alteração muda o projeto completo, pois novas instalações no piso da cozinha, para o gás e para a eletricidade precisam ser indicadas para a execução em obra, por exemplo.

Também destacam que falta clareza na definição do que realmente será feito na obra da cozinha, como a altura final do pé direito, tipo de revestimento das paredes, se é possível alterar as instalações hidráulicas e a listagem com os eletrodomésticos que devem ser considerados em projeto, entre outros itens. Neste cenário, o projeto vai e volta muitas vezes entre o comercial e o departamento técnico, e por mais que seja o mesmo projetista quem fará as revisões, eles reconhecem que alguma informação pode passar despercebida. Entre tais informações, que foi apontada pelos profissionais ligados à assistência técnica e comprovada durante as montagens destaca-se principalmente os erros de medida causada 
por inversão de números, como no caso de paredes de $2580 \mathrm{~mm}$ que são erroneamente interpretadas pelos projetistas como $2850 \mathrm{~mm}$ e vice versa, por exemplo.

Por meio de seus relatos, os projetistas comparam os projetos de até poucos anos atrás com os projetos que estão sendo desenvolvidos atualmente, os quais tem exigido muito mais dedicação técnica. Nos projetos de cozinhas de apartamentos compactos destacam a precisão que precisam ter com todas as medidas, já que o espaço é limitado. Entretanto, relatam que em muitos destes projetos os vendedores fazem as previsões erradas dos módulos e eletrodomésticos e o que foi previsto em projeto inicial não pode ser feito em projeto executivo. Em todo caso, relatam que o mesmo acontece nos projetos de cozinhas mais avantajadas, em que se tem como inspiração os modelos de cozinhas de marcas europeias, com módulos autoportantes e sistemas construtivos de módulos superiores presos ao teto, por exemplo, que não são compatíveis com o que o mercado nacional oferece de ferragens. Tudo isto resulta em projetos bonitos, mas que são tecnicamente inviáveis.

Ana Claudia Amado (2016), projetista há vinte e oito anos, acredita que boa parte destas revisões poderia ser evitada se o vendedor tivesse o domínio técnico do móvel para cozinha. Segundo ela, "é o mesmo problema há anos, o vendedor tem medo de perder a venda para outra empresa e aceita fazer para o cliente soluções que na prática não funcionam". Nestes casos, destaca a responsabilidade do projetista que não deve começar o projeto até que o vendedor primeiro defina todos os itens com os clientes. Entretanto, reconhece que em muitos casos, por pressão da gerência ou do próprio vendedor, os projetos são feitos sem todas as informações necessárias. Marcelo de Souza (2016), analista de pós venda, acrescenta "a maior parte das soluções não resolvidas em projeto executivo sobram para os montadores resolver (...) é como montar protótipo na casa do cliente".

De maneira geral, quanto à formação técnica dos projetistas, assim que são contratados recebem um treinamento formal, geralmente realizado por um projetista mais experiente e com um intervalo de tempo de 15 a 30 dias já começam a preparar os projetos executivos dos vendedores. Um dado importante é que a distribuição dos projetos executivos respeita uma ordem de fila única, ou seja, projetos grandes, médios ou pequenos, de baixa ou alta complexidade, são distribuídos aleatoriamente, conforme a disponibilidade dos projetistas e não conforme a sua experiência ou domínio técnico, o que pode representar outra circunstância que favoreça a ocorrência de erros durante a montagem dos móveis. 


\subsection{Análise dos resultados obtidos durante a montagem dos móveis}

Conforme foi informado no capítulo 3, a coleta de dados com os montadores seja por meio das entrevistas ou durante as observações em campo no processo de montagem, aconteceu em duas fases: em 2015, de outubro a dezembro e na segunda fase, de julho a dezembro de 2016, para que os dados obtidos na primeira fase pudessem ser comparados com os dados obtidos na fase seguinte. Esta estratégia contribuiu para a validação dos padrões recorrentes identificados durante o tratamento dos dados.

\subsubsection{Circunstâncias geradoras de descarte e tipos de materiais descartados}

Baseado na análise dos dados obtidos durante a montagem dos móveis, realizada na casa dos clientes, dentro das circunstâncias responsáveis pelo descarte de materiais, foi possível identificar quatro grandes categorias, que são detalhadas adiante considerando-se seus aspectos mais representativos:

- Linguagem do projeto executivo;

- Incidência de erros, dos montadores, dos projetistas ou da fábrica;

- Condições físicas dos espaços em que as cozinhas são montadas;

- Manuseio das peças;

No que se refere à linguagem do projeto, é importante lembrar que no segmento de móveis para cozinhas moduladas, o manual de montagem é um kit formado pelo projeto executivo e a sua listagem de peças. Da mesma forma, o projeto executivo é uma compatibilização entre o levantamento métrico do espaço e o que foi vendido no projeto inicial, servindo como um documento de compra utilizado na etapa comercial que formaliza por meio de um desenho técnico, em planta e vistas, os itens adquiridos pelo cliente. Este projeto executivo é bem detalhado, entretanto ele é um projeto especialmente desenvolvido para o cliente e não contém informações que sejam específicas para os montadores e que funcione integralmente como um manual. Entre tais informações específicas para a montagem, destacam-se as linhas de cotas, que em determinados momentos não são indicadas ou quando indicadas, não são compatíveis com as medidas reais do espaço. Somado a isto, em muitos casos falta a indicação da distância dos módulos em relação às paredes, da definição de onde começa e termina a modulação. Sem contar que na maioria das montagens observadas, havia nos projetos de instalação a indicação de cotas com medidas tais como, 967 mm, apresentando unidades métricas difíceis de serem executadas, pois as ferramentas as quais os montadores dispõem não permitem tamanha precisão de medidas. 
Uma situação bem recorrente na análise dos projetos durante as montagens ocorre na indicação das cotas referente ao distanciamento dos módulos em relação às paredes. No exemplo abaixo, baseado no acompanhamento do processo de montagem da cozinha apresentada na figura 28 , subentende-se que a modulação ocorre na indicação das cotas referentes, porém não há indicação destas medidas, tanto no módulo inferior de canto quando no módulo superior. Outra situação recorrente ocorre no posicionamento de módulos superiores, pois subentende-se que eles deverão ser centralizados com a coifa e alinhados com o final da bancada esquerda, porém tanto os eletrodomésticos quanto as bancadas são instalados após a montagem da cozinha, ou seja, o montador ainda não tem a referência destes itens.

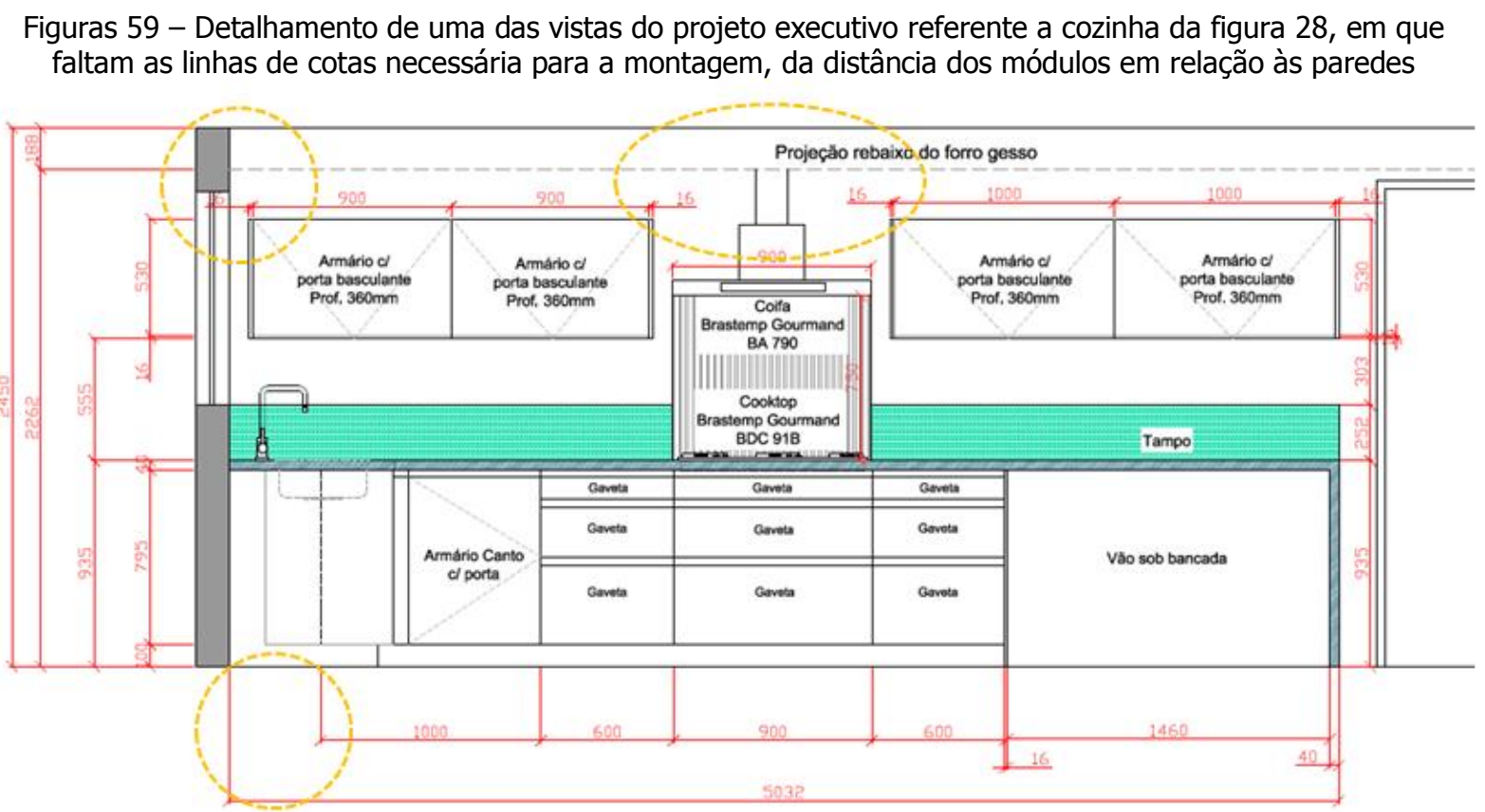

Fonte: Arquivo do autor.

Durante a coleta de dados foi possível perceber outros contratempos relacionados às linhas de cotas, o que em muitas ocasiões obriga os montadores a refazer o trabalho, tendo que desmontar todo o conjunto de módulos. Em outras ocasiões, dependendo da maneira como os módulos foram fixados na parede, tais ajustes não são possíveis e, desta forma, alguma das peças não poderá mais ser aproveitada, gerando descarte de materiais e a produção de uma nova peça na indústria.

Neste próximo exemplo, ilustrado na figura 60, conforme a indicação da linha de cota, a modulação da cozinha começa da esquerda para direita. À parte o fato de que as quatro linhas de cotas verticais possuem medidas divergentes entre si, esta vista do projeto 
considera um pequeno espaço de sobra de parede do lado direito, sem módulos e por mais que não esteja indicado, em obra constatou que era de aproximadamente $40 \mathrm{~mm}$. Durante a montagem percebeu-se o ocorrido, de forma que toda a modulação teve que ser deslocada para a direita, acarretando a produção de um novo painel, em substituição ao painel original de $529 \mathrm{~mm}$, que foi inutilizado. Segundo o montador Antonio dos Santos (2016) "dá a impressão que o pessoal do projeto pensa o móvel isolado, não como um conjunto e na montagem da cozinha isto é complicado, porque a modulação é amarrada com tudo".

Figura 60 - Vista de uma das paredes de projeto executivo de cozinha, utilizado pelos montadores

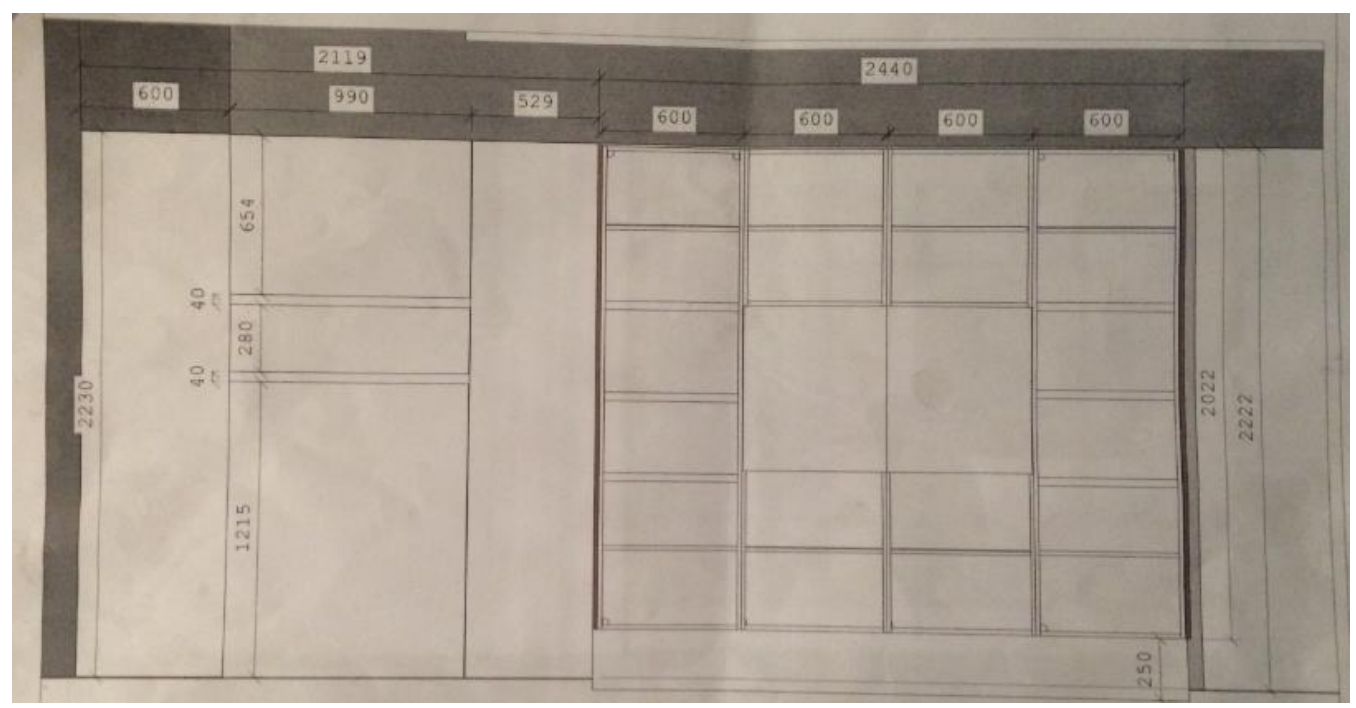

Fonte: Arquivo do autor

Também quanto às informações para os montadores, neste segmento de móveis que os projetos possuem arranjos personalizados, em muitos casos faltam detalhes construtivos necessários para a montagem dos módulos e que possivelmente foram acordados na etapa comercial e repassados aos projetistas. Outro exemplo que chamou a atenção durante o acompanhamento das montagens foi um caso em que havia a indicação no projeto de que todas as paredes da cozinha deveriam ser "revestidas" com o mesmo material da frente dos módulos e, para este fim, foram solicitados painéis avulsos de MDP com $18 \mathrm{~mm}$ de espessura. Entretanto, em nenhum lugar do projeto constava uma instrução de como isto deveria ser feito ou quais ferragens utilizar, o que obrigou os montadores a improvisar uma estrutura de madeira na parede para fixação destes itens. Ainda, alguns recortes precisaram ser feitos para acesso aos dois quadros de luz e aos pontos para televisão no canto superior. Naturalmente, a colagem manual da fita de borda para acabamento destes recortes no topo dos painéis e a junção entre um painel e outro não ficou bem acabado o que já indicava a substituição de tais peças. Como agravante, no caso do revestimento madeirado escolhido 
para o revestimento, a troca de alguns painéis faria com que a estampa perdesse a continuidade e, sendo assim, um total de sete painéis de MDP tiveram que ser substituídos.

Figura 61 - Montadores improvisando uma estrutura de madeira na parede para fixação de painéis
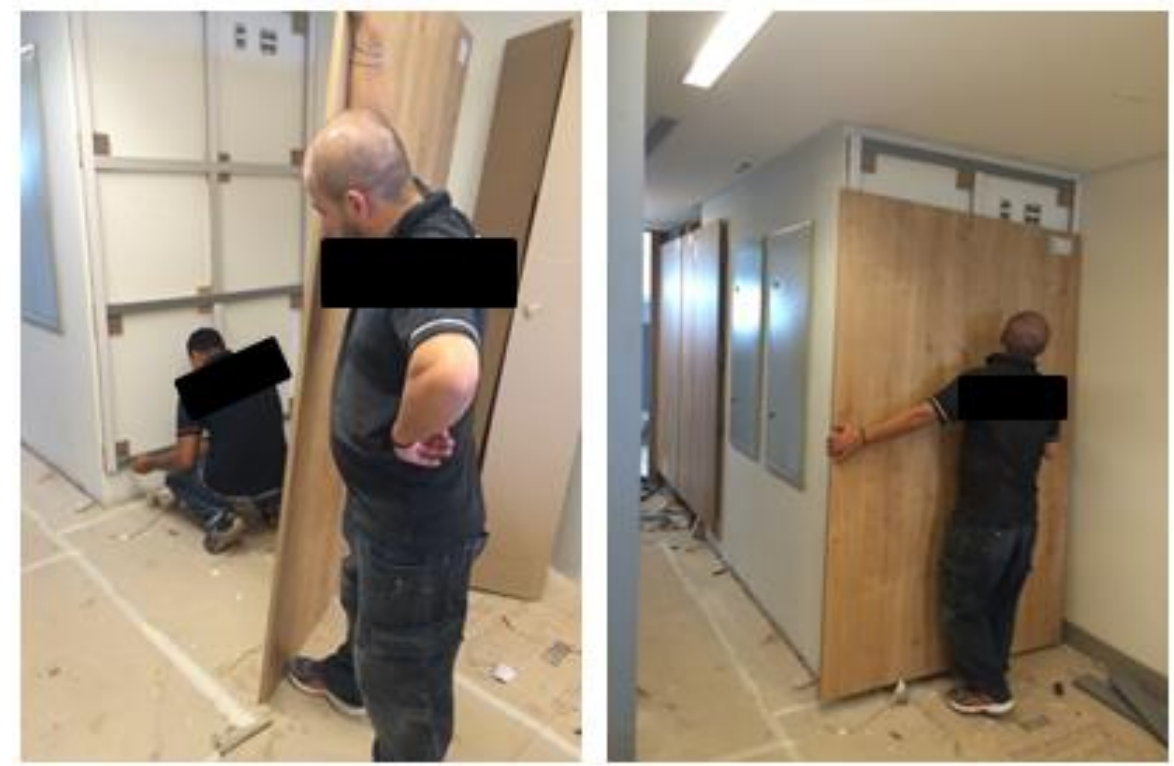

Fonte: Arquivo do autor

Cabe ressaltar que a indústria não faz avaliações técnicas dos projetos. A indústria produz os móveis de acordo com a lista de peças enviada pelos projetistas, sendo deles a responsabilidade técnica quanto aos itens que serão entregues e como serão instalados.

Mesmo assim, a troca de peças ou ajustes nos módulos durante a montagem são características recorrentes, podendo ser identificadas em todas as situações a figura do analista técnico de pós-venda, profissional responsável por organizar a substituição de tais produtos.

Marcelo de Souza (2016) analista de pós-venda, destaca a falta de conhecimento técnico por parte de alguns vendedores, que em determinados casos vendem projetos bem elaborados no sentido estético, mas que são difíceis de montar. Do ponto de vista do projeto executivo, ele defende a responsabilidade dos projetistas que devem avaliar tecnicamente como o projeto vendido será montado, apontando as devidas ressalvas. Entretanto, reconhece que a sobrecarga de função nos projetistas é cada vez maior e que falta tempo para análises em profundidade do projeto vendido.

Somado a estes fatores, Patrícia Campiol (2016) coordenadora de projeto e pós-venda acrescenta o fato de que os prazos para o projetistas desenvolveram os projetos executivos 
estão cada vez mais curtos, porque os clientes não querem esperar muito tempo para a entrega dos móveis. Portanto, preparar a lista de peças que é uma atividade que requer atenção e checagens consecutivas, acaba muitas vezes sendo feita às pressas, o que dá abertura para erros.

Segundo relato dos projetistas há também um descontentamento por conta das sucessivas revisões de projeto, o que também pode ser um fator que contribua para a ocorrência de erros em cadeia: no projeto executivo, na lista de peças e que resulte em peças inadequadas para a montagem. Em geral, o projeto executivo da cozinha é composto por uma média de quinze páginas, contendo plantas e vistas. Uma característica percebida nestas revisões, talvez por distração dos projetistas, é a alteração somente de uma das partes, que resulta em informações divergentes entre as páginas do projeto e que dá abertura para interpretações equivocadas por parte dos montadores.

Sob o ponto de vista dos montadores, destacam que a impressão de todas as folhas do projeto também não faz sentido, pois a maior parte do conteúdo apresentado não é específica para a montagem e, desta forma, não será usada pelos montadores, gerando ruído e não informação.

Outra crítica dos montadores é quanto à ausência de instruções relacionadas aos produtos de lançamento - sejam novas ferragens, sistemas ou componentes construtivos dos módulos. Em muitos casos, não é detalhado tecnicamente os procedimentos de uso destes novos produtos, abrindo caminhos para interpretações subjetivas e que pode não ser a melhor estratégia na tomada de decisões. No que se refere especificamente ao lançamento de ferragens, Souza (2016) destaca que a modulação é extensa e desta forma a indústria não faz protótipo de todos os itens, pois isto inviabilizaria qualquer tipo de lançamento.

No caso de novos produtos, a indústria segue a especificação técnica do manual dos fabricantes de ferragens e componentes, que apontam o uso apropriado de cada produto. Entretanto, reconhece que pode haver falhas na combinação destas ferragens com outros materiais, situação geralmente identificada na montagem, sendo necessária, nestes casos, a abertura de um chamado de serviço assistência técnica, para a substituição dos itens.

Como erros mais recorrentes do departamento técnico e que ocasionam a substituição de produtos e descarte de materiais, Souza (2016) e Campiol (2016) destacam o erro de interpretação da medição, principalmente com a inversão dos números, como por exemplo, 
uma parede que foi indicada no levantamento métrico com a medida $3350 \mathrm{~mm}$ foi considerada pelo projetista com $3530 \mathrm{~mm}$, sendo necessário neste caso reduzir a modulação em 180 mm, o que é uma medida considerável. Segundo eles, a maioria destes casos só é descoberta na vistoria, com os móveis sendo produzidos.

Outros erros são comumente caracterizados pela interpretação equivocada dos manuais dos eletrodomésticos, principalmente no caso de produtos embutidos e importados. Uma peça que merece ser destacada são os módulos para embutir forno elétrico e micro-ondas, que possuem um acabamento frontal chamado de "máscara", substituída ou ajustada na quase totalidade dos casos analisados, pela indicação errada de medidas no projeto executivo. Nota-se na figura abaixo que a máscara de acabamento para o forno elétrico e o micro ondas é uma medida variável, definida conforme o manual do fabricante, tais como Brastemp, Electrolux, entre outros.

Figura 62 - Projeto de cozinha modular com a instalação de eletrodomésticos embutidos nos módulos

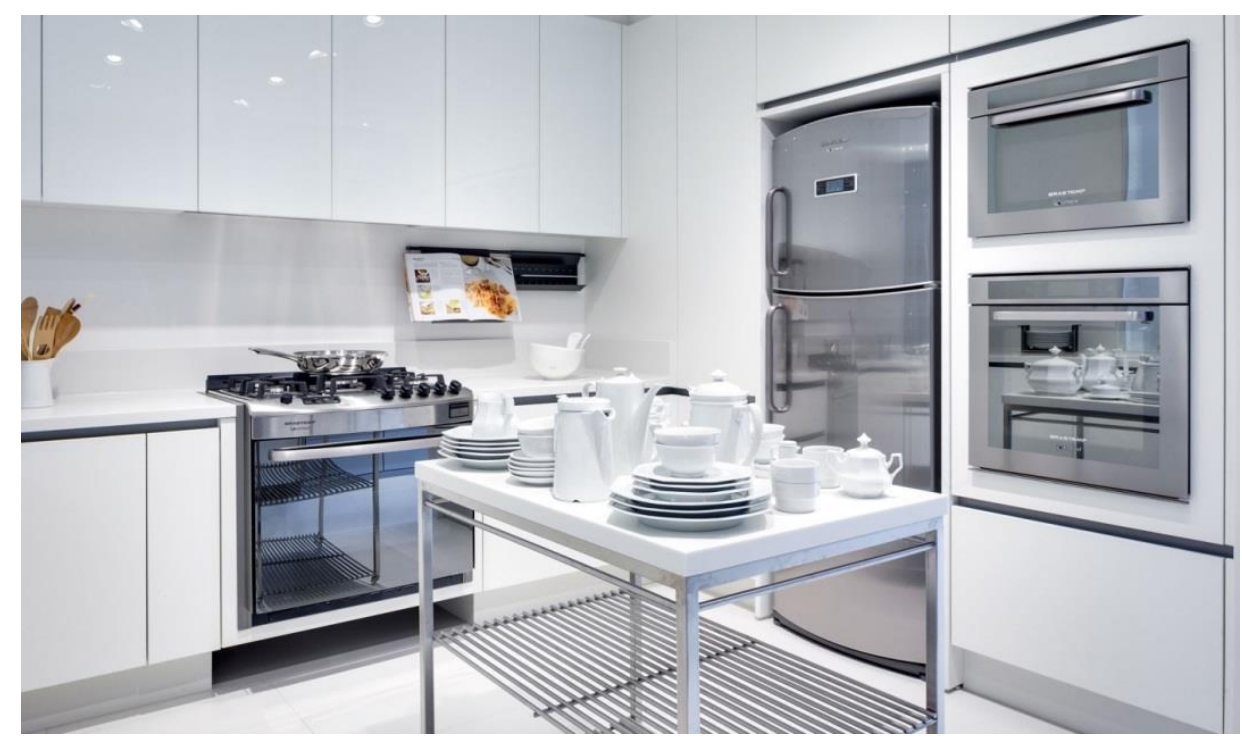

Fonte: http://www.kitchens.com.br/cozinha.php. Acesso em: 07 fev.2017

Algumas peças enviadas pela fábrica, também puderam ser identificadas em discordância com as ferramentas disponíveis pelos montadores. Entre tais peças, merece destaque as que os montadores com muita dificuldade conseguirão ajustar em obra, por conta da incompatibilidade entre as máquinas industriais e as ferramentas de corte disponíveis nos locais de montagem.

O exemplo a seguir mostra um conjunto de quatro prateleiras, fixadas direto na parede e sem o uso de mão francesa. No processo industrial deste produto é feita uma usinagem no 
interior da prateleira para encaixe do suporte oculto. Entretanto, somente uma peça foi enviada com esta usinagem (figura 63a), o que exigiu que o montador fizesse a usinagem das demais prateleiras na casa do cliente (figuras 63 b e c). Além do tempo para execução deste serviço, na qualidade regular do resultado quando comparado ao processo industrial, estas situações de ajuste de peças de madeira reconstituída em obra também geram pó de serra, como pode ser verificado nas imagens abaixo.

Figura 63a - Prateleira avulsa enviada para a montagem com usinagem de fábrica para fixação da ferragem

Figura 63b e 63c - Montador fazendo a usinagem para fixação da ferragem no hall da casa do cliente
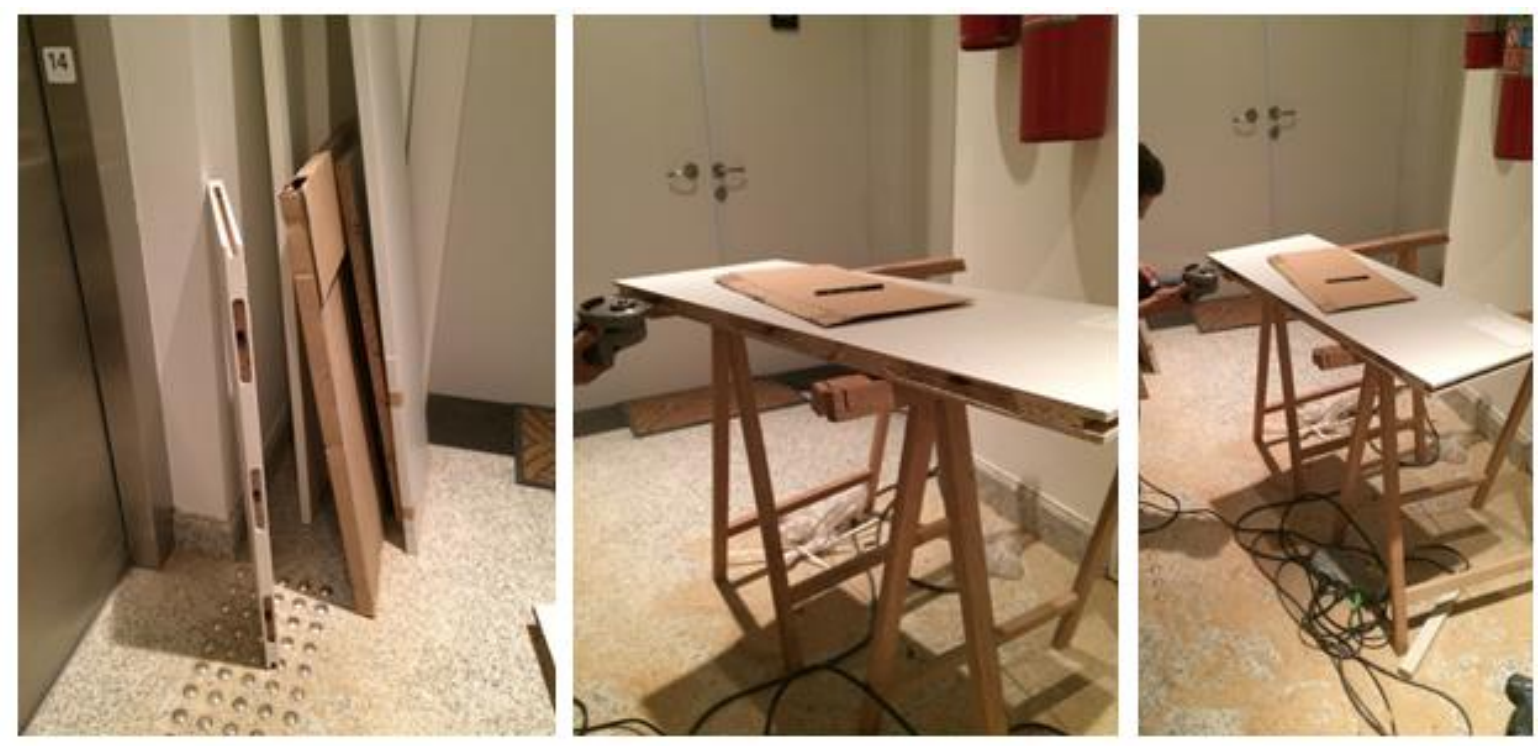

Fonte: Arquivo do autor

Quanto aos erros recorrentes atribuídos aos montadores e que ocasionam descarte de materiais na montagem, podem ser destacados alguns descuidos com os materiais e quanto à organização do local de trabalho. Como relatado pelos projetistas, os tamponamentos e algumas peças de acabamento são enviadas alguns centímetros maior na altura e na profundidade, para que sejam ajustados pelos montadores em obra. Em alguns casos, por descuido durante o corte com a serra, os instaladores acabam tirando mais do que o necessário, o que inutiliza a peça. Outra ocasião recorrente de descuido pode ser identificada quanto ao relato por parte dos montadores de "peças faltantes". Como o volume de peças entregues em uma cozinha é grande, muitas vezes há certa dificuldade em encontrar determinado item no montante de itens que foram entregues. Sendo assim, os montadores solicitam novas peças para a assistência técnica ou para o supervisor de montagem, que providencia a sua substituição. Entretanto, de maneira geral, estes itens são encontrados até 
o final da montagem, o que gera material em duplicidade, e consequentemente descarte de uma das peças, a nova ou a original.

Günter Bschor (2016), montador de cozinhas há mais de vinte anos, destaca a frequente relação de incompatibilidade entre o projeto e a arquitetura da cozinha, e que naturalmente resulta em ajuste nos produtos ou troca de peças. Ele identifica algumas situações recorrentes nesta relação, que puderam ser comprovadas durante a coleta de dados e que impactam diretamente na geração de descarte de materiais.

Entre tais situações, pode-se destacar o desconto dos revestimentos, que geralmente é realizado quando o espaço da cozinha está em uma fase de obra, com as paredes ainda no tijolo ou na massa grossa. Como na maioria dos casos, entre a venda e a entrega dos produtos o prazo é de 45 a 60 dias útil, para que o processo de entrega dos móveis para cozinha não se estenda por muitos meses, é de praxe que a produção industrial ocorra paralela às mudanças na arquitetura. Neste cenário, o desconto dos acabamentos e revestimentos é fundamental, pois fará uma previsão da medida final das paredes para encaixe da modulação. Naturalmente, para cada acabamento, seja tijolo, massa grossa, massa fina, pintura, há um desconto específico. A mesma regra vale para os revestimentos, sejam cerâmicos, cimentícios ou laminados. Em todo caso, ora por falta de conhecimento do medidor, ora por inexperiência do projetista ou até mesmo por especificação de materiais que mudam no meio do processo, o cálculo deste desconto muitas vezes está errado, entretanto, só é percebido no momento da vistoria ou da montagem com os móveis já produzidos e muitas vezes já entregues na casa dos clientes. Assim, quando possível, estas peças são ajustadas em obra pelos montadores. Do contrário, as peças originais são descartadas e a indústria produzirá novas peças.

A instalação do forro de gesso nos ambientes é outra etapa que geralmente acontece junto às alterações na arquitetura, antes da entrega dos móveis. Por esta razão, da mesma forma é feita uma previsão quanto à altura do pé direito, medida que precisa ser rigorosamente respeitada, principalmente tratando-se de modulação piso-teto. Principalmente nestes casos, pode ser encontrada divergência de medidas, sendo necessário o ajuste de algumas peças na altura.

Nas montagens observadas, foi possível identificar muitas pessoas trabalhando ao mesmo tempo e no mesmo espaço, o que torna os locais de montagens das cozinhas muito 
movimentados. Entre tais serviços realizados ao mesmo tempo, destacam-se ajustes no forro de gesso para iluminação e no serviço de profissionais como encanadores, eletricistas e pintores. Estes profissionais atrapalham os montadores e, em alguns casos, os seus equipamentos danificam a superfície dos móveis. Por esta razão, muitas empresas estão exigindo dos clientes a assinatura de termos de responsabilidade, quanto a eventuais danos causados nos móveis durante a montagem da cozinha. Em outras empresas, além deste termo, os montadores isolam os acessos do ambiente, para que não haja a interferência de outros fornecedores até que a montagem esteja concluída.

Figura 64a - Registro fotográfico durante a montagem de uma cozinha, em que o forro de gesso precisou ser aberto para a passagem de conduítes elétricos

Figura 64b - Registro fotográfico da pintura em spray das portas da cozinha acontecendo junto com a montagem dos móveis
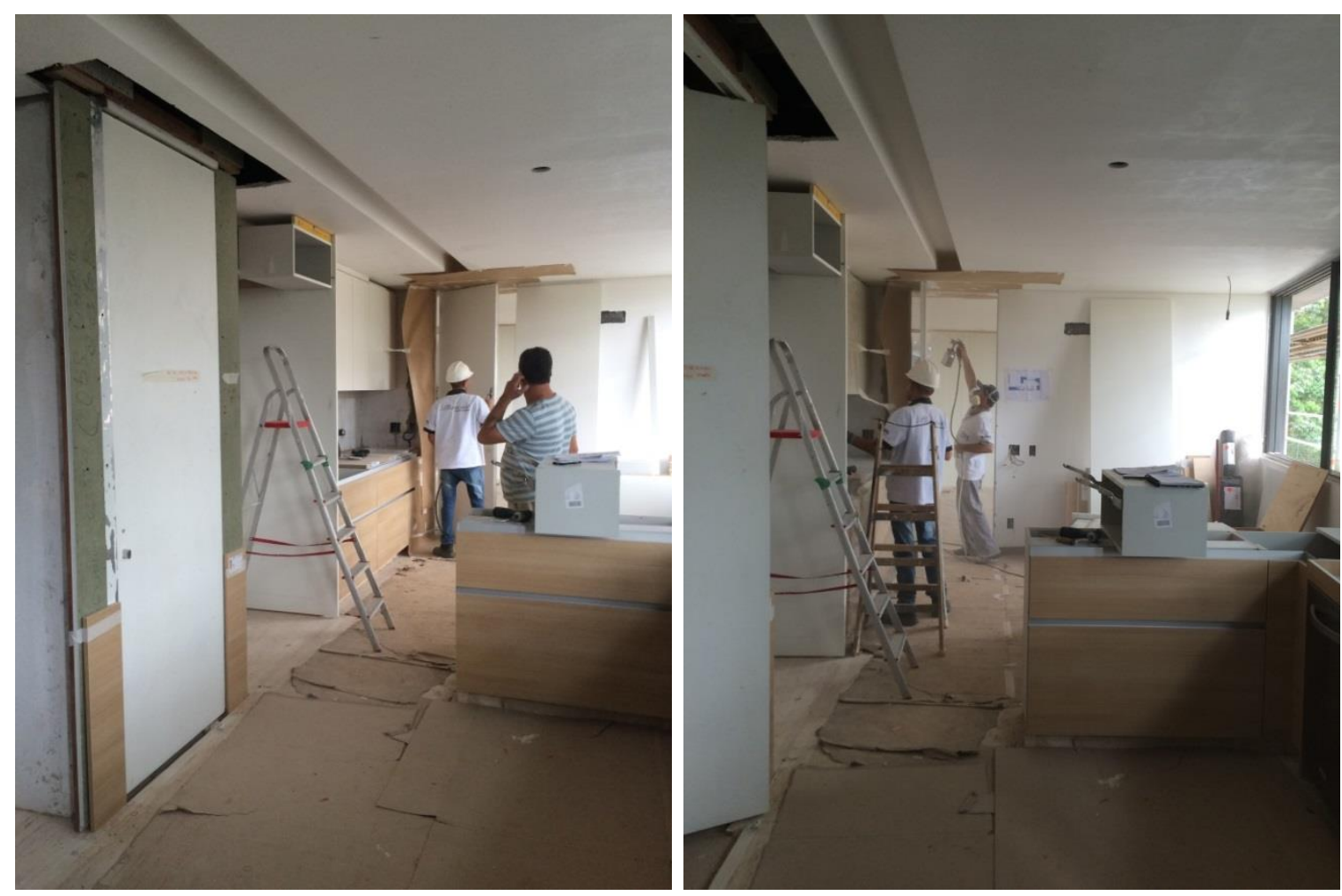

Fonte: Arquivo do autor

Somado a isto, no momento de desembalagem dos produtos nos locais de montagem, puderam ser identificadas algumas peças danificadas, principalmente as peças grandes, como portas e tamponamentos. Como verificado na expedição das indústrias, antes de serem embalados, os módulos e demais peças da cozinha passam por um controle de qualidade, são analisadas e conferidas, de modo que, caso as peças danificadas fossem identificadas na etapa industrial, neste momento seria providenciado o seu ajuste ou o seu descarte. Ainda que esta abordagem deva ser explorada com mais profundidade, os 
montadores deduzem que sejam ocorrências no transporte, com o manuseio das peças no percurso da transportadora, das indústrias até a sua entrega nos locais de montagens. Nas figuras abaixo pode ser observado algumas ocorrências de portas batidas, referente às frentes de dois módulos da cozinha apresentada na figura 28. Nota-se que pelo estado em que as portas se encontram, o seu ajuste não é possível, resultando no seu descarte, e na geração de resíduos sólidos.

Figuras 65a e b - Topos de algumas portas de módulos de cozinha danificadas, identificadas no momento da montagem
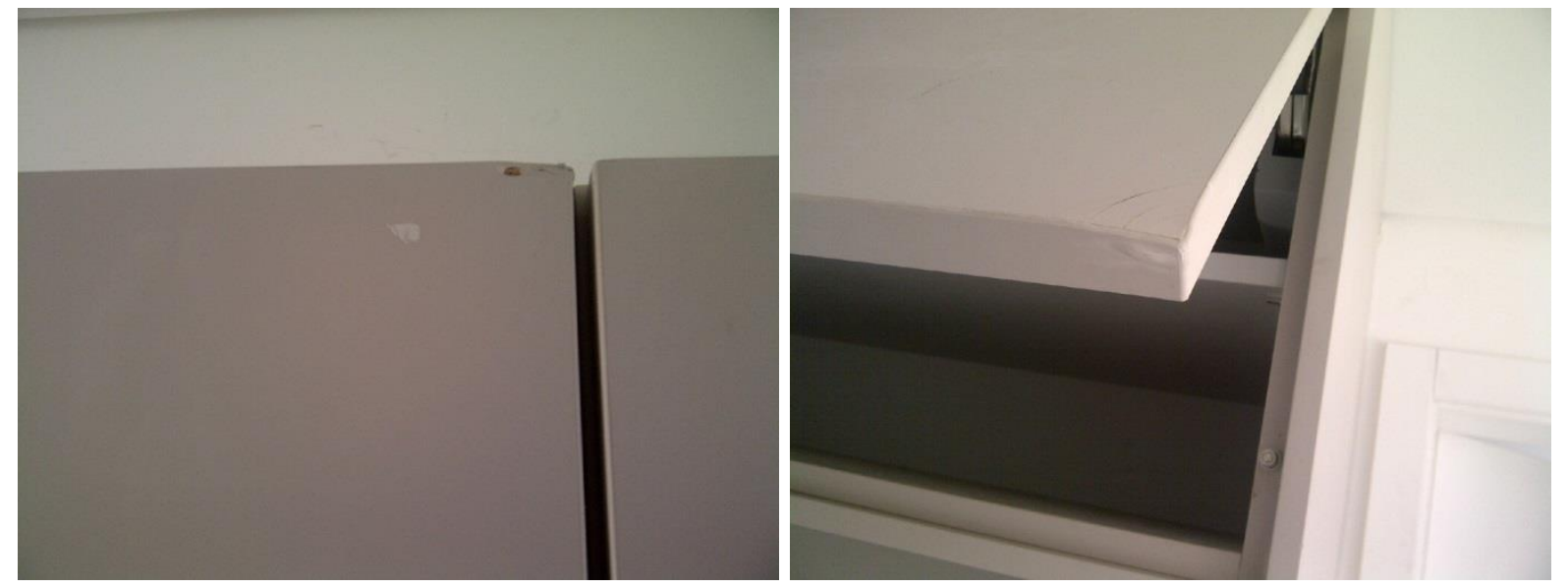

Fonte: Arquivo do autor

Assim, baseado no exposto, o tipo de peças que precisarão ser substituídas ou ajustadas em obra é bem diverso e variam desde as partes de um módulo, como laterais, base ou fundo, alguns tipos de tamponamentos, prateleiras e até mesmo ferragens e frentes dos módulos. Naturalmente, a troca ou ajustes destas peças ocasiona descarte de materiais; no caso dos ajustes, uma parte da peça precisa ser retirada para adequação. No caso de troca, a peça original será descartada por inteiro, sendo substituída por outra, conforme listagem de peças.

Ainda que não seja o objetivo desta investigação, a troca destes itens ocasiona certo desgaste aos clientes, pois uma nova peça precisa ser produzida e isto para a indústria não é imediato. Como recurso temporário, em alguns casos, mantem-se a instalação da cozinha com as peças danificadas, até que seja produzida a nova peça para substituição, o que causa uma impressão de falta de qualidade nos produtos. Da mesma forma, para a indústria estes incidentes embutem custos, como a produção de novas peças, logística, transporte e custo/hora do montador retornar aos locais da montagem. 


\subsubsection{Destinação dos materiais descartados}

Quanto à destinação dos materiais descartados na etapa de montagem foi possível identificar três cenários distintos, que variam conforme a indústria e os montadores.

Em um primeiro cenário, as peças substituídas retornam para a indústria, para que seja feito o seu descarte nas caçambas de coleta de resíduos sólidos industriais, o que implica em custo de frete para buscar estas peças nos locais de montagem e leva-las até as fábricas. Conforme o deslocamento, este frete pode sair mais caro que o valor da peça a ser descartada. Assim como acontece em boa parte dos resíduos gerados na etapa de produção industrial, segundo os critérios econômicos, o reaproveitamento é mais custoso do que o descarte.

Outra destinação para este material fica sob responsabilidade dos montadores que, mediante a autorização da empresa, absorvem o material e o levam para as suas residências. Como a grande maioria dos montadores entrevistados tem formação em marcenaria e possuem as suas próprias ferramentas, relataram que utilizam este material para a manufatura de pequenos móveis e objetos. Vale ressaltar que nem todos os montadores possuem automóveis e nem sempre residem próximo aos locais das montagens, logo, esta prática é pontual.

Por fim, a destinação mais recorrente verificada para este material é o seu descarte nas caçambas de coleta de resíduos sólidos nos condomínios ou até mesmo a caçamba de coleta da própria obra, uma vez entendido que esta caçamba é contratada para a coleta dos demais resíduos da construção civil, originários da reforma do imóvel em que as cozinhas são montadas. Por conta das características e limitações identificadas nos dois tipos de destinação anteriormente apresentados, o uso destas caçambas de obra para o descarte dos resíduos sólidos gerados na etapa da montagem das cozinhas acaba sendo o mais utilizado. 
Figura 66 - Foto de caçamba de coleta de resíduos sólidos de construção civil junto com descarte dos resíduos sólidos industriais gerados durante a montagem de móveis para cozinhas, identificado pelo pontilhado amarelo

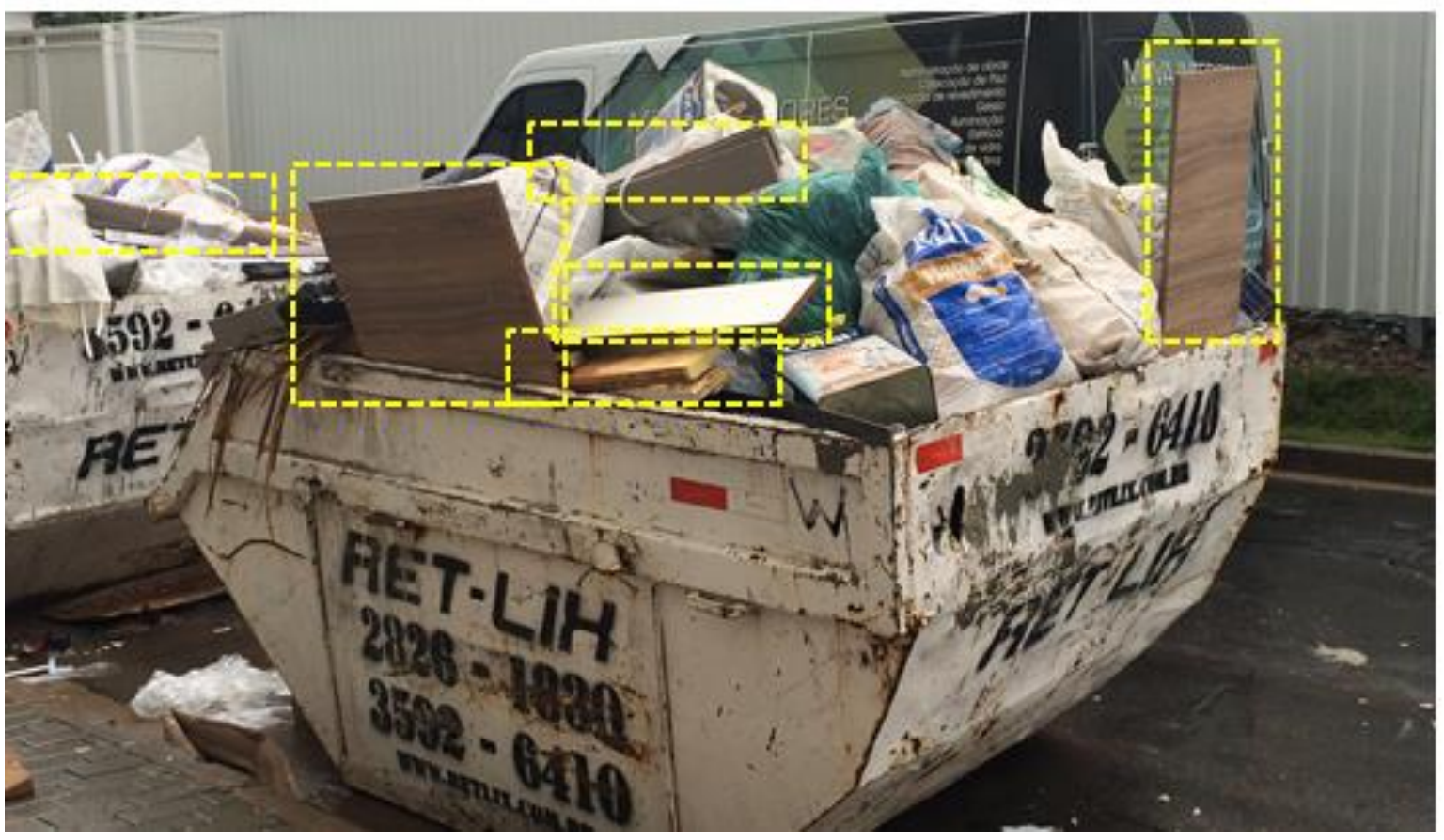

Fonte: Arquivo do autor. 
5. Considerações Finais 
O objetivo desta pesquisa foi o de investigar, a partir de um ponto de vista interdisciplinar entre design e sustentabilidade, as circunstâncias responsáveis por gerar resíduos sólidos industriais no segmento de móveis modulados para cozinha, para gerar um panorama qualitativo do tema e identificar como o design entra - ou deveria entrar - neste processo para reduzir o montante de descarte de materiais gerados.

Em primeiro lugar, nas três etapas investigadas do processo - produção industrial, projeto e montagem - cabe destacar que as peças e os materiais que são descartados caracterizam-se no que Manzini e Vezzolli (2011) definiram como descarte pré-consumo, ou seja, são materiais novos que podem retornar ao processo de produção servindo de matéria prima para a produção de novos produtos. Ainda assim, são tratados como resíduos sólidos por não haver o planejamento do seu retorno ao ciclo produtivo e só se tornam resíduos por conta do seu contexto (LEONARD, 2011).

De qualquer forma, como foi relatado pelos profissionais envolvidos, se considerado apenas as condições econômicas, o reaproveitamento é mais caro do que a peça nova, o que é uma condição facilitadora do descarte de materiais e a geração de resíduos sólidos neste segmento de produto. Porém, é necessário recordar que o conceito de sustentabilidade se apoia em três pilares, ambiental, social e econômico e, desta forma, todos os pilares devem ser igualmente considerados.

Particularmente quanto aos fatores ambientais, principalmente no que se refere ao destino destes resíduos retomam-se aqui a hierarquia de objetivos definidos na Lei 12.305/10: a reutilização (1) dos materiais é um processo que deve anteceder a reciclagem (2) o tratamento (3) e a disposição final (4) destes materiais nos aterros sanitários. Entretanto, baseado nos resultados obtidos, quanto à sua reutilização pode-se perceber que, em muitos casos, este material é descartado direto nas caçambas de coleta. Quanto ao tratamento e disposição destes materiais nos aterros, os dados parecem imprecisos, devido ao não interesse por parte dos receptores em participar desta investigação, o que abre alguns caminhos para novas pesquisas. Por último, quanto à reciclagem da madeira, algumas iniciativas como o Programa de Reciclagem da Madeira da empresa Eucatex, poderiam ser mais incentivados no contexto industrial brasileiro. Na sede desta indústria, na cidade de Salto, interior de São Paulo, os resíduos sólidos de madeira, provenientes de múltiplas fontes, são coletados para transformação em biomassa, combustível renovável para geração de energia. 
No caso dos materiais utilizados, é possível concluir que a madeira reconstituída é o material predominante na produção dos módulos e, consequentemente, o material que representa a maior parte do volume de resíduos sólidos gerados nas indústrias de móveis modulados para a cozinha. Em termos produtivos, é um material que se desenvolveu bem no decorrer do século XX e XXI principalmente por suas características técnicas que são mais favoráveis para a industrialização de móveis em larga escala. À mesma maneira, seu uso representou uma alternativa mais ecológica quando comparado ao uso da madeira nativa. Em todo caso, diante da atual preocupação com a geração e a destinação dos resíduos sólidos, há que se refletir sobre o uso deste material em projetos de produto, que em uma rápida análise, baseada na trivialidade de como é feito o seu descarte, pode-se perceber que a ele não tem se dado o devido valor, não somente financeiro, mas simbólico, principalmente.

Quanto ao método utilizado na pesquisa, com a coleta de dados realizada por meio da observação não participante, nas indústrias e nas montagens das cozinhas, tal estratégia se mostrou bem adequada: possibilitou o acesso a determinados conteúdos que talvez não tivessem sido alcançados se fosse considerada a coleta de dados somente por meio das entrevistas. Também o cruzamento de dados entre as entrevistas e a observação possibilitou comparar as informações entre o que foi dito nas entrevistas e o que foi percebido em campo.

\subsection{Considerações sobre a produção industrial}

Quando comparado às etapas de projeto e montagem, na produção industrial as circunstâncias que geram o descarte dos materiais são mais facilmente percebidas, porém como resultado do descarte, os resíduos sólidos são difíceis de serem classificados, por conta das muitas variáveis encontradas nos acabamentos dos produtos, como espessuras, materiais, revestimentos, etc. e, por esta razão, estudos quantitativos relacionados a este segmento talvez apresentem dados não muito precisos.

Como resultado das muitas variáveis nos produtos, os resíduos sólidos gerados são sazonais e não padronizados, característica que tem se mostrado como uma das principais razões que dificultam o aproveitamento dos materiais dentro da indústria e no seu retorno ao ciclo produtivo. De qualquer maneira, como apontado pelos diretores industriais, a palavra "custo" no contexto industrial tem um significado muito importante; no caso da venda destes resíduos para outros fabricantes, além de contribuir com a redução do montante de resíduos 
sólidos que eventualmente poderiam seguir para os aterros sanitários, a prática da venda também contribui para o surgimento e o desenvolvimento de empresas e indústrias menores e no fomento do empreendedorismo para pequenos produtores independentes.

Do ponto de vista das iniciativas de aproveitamento dos materiais relatadas pelos industriais entrevistados, o dado comum que pode ser observado nestes relatos é que tais práticas de aproveitamento não buscaram somente resolver a destinação do material, mas tentaram até certa medida incorporar grupos de pessoas e instituições que precisavam de algum tipo de auxílio financeiro, estabelecendo, desta forma, uma relação de parceria com as indústrias de móveis.

Somado a isto, o fornecimento dos resíduos sólidos pré-consumo para entidades carentes, instituições ou organizações não governamentais, que supostamente utilizam os resíduos para a manufatura de objetos, é um conceito que a cada dia vem se consolidando por meio de iniciativas da economia circular, que tem como preceito o entendimento dos resíduos sólidos como moeda capaz de transformar os ciclos produtivos lineares em processos mais fluidos que, entre outras coisas, possibilita a redução de lixo. Entretanto, há que se considerar a necessidade de qualificação profissional aos membros destas instituições, pois o aproveitamento da madeira requer respeito a normas de segurança específicas, conhecimento das ferramentas e habilidades técnicas.

Ainda no que se refere ao aproveitamento de materiais para manufatura de produtos, complementar à coleta de dados para esta pesquisa, em agosto de 2016 o autor desta Dissertação participou de uma oficina de reaproveitamento de retalhos de madeira, no OficinaLab, em São Paulo. A oficina, oferecida para o público em geral, tinha como objetivo a criação de produtos a partir do descarte de madeira reconstituída e nativa, provenientes de marcenarias da grande São Paulo. Como os dez participantes eram vinculados à área de design e arquitetura, o resultado foi a produção de alguns modelos físicos, atividade de criação que poderia ser replicada para a geração de protótipos ou mock-ups ${ }^{10 .}$, em outros contextos, como universidades e indústrias, por exemplo.

Outro aspecto relevante quanto ao aproveitamento dos materiais descartados são as tentativas de incorporação da universidade nestas práticas, o que deve possibilitar aos

\footnotetext{
${ }^{10}$ Para Lima (2006, p.29), Protótipo é um modelo em escala natural (1:1), com material igual ou semelhante ao especificado no projeto. Mock-up é um modelo em escala natural (1:1) com material diferente ao especificado no projeto.
} 
futuros profissionais da área de design reflexões que resultem em produtos que possam ser concebidos considerando como requisito de projeto os seus aspectos ecológicos e a sustentabilidade - em seus três pilares, ambiental, social e econômico. Da mesma forma, defende-se aqui que a não geração dos resíduos sólidos industriais deve começar por uma metodologia de projeto de design, que seja capaz de considerar o aproveitamento dos materiais no planejamento do produto, somado à visão sistêmica de projeto que considera dados provenientes desde fornecedores até montadores e usuários. Só assim poderá ser reduzido o montante de resíduos que são gerados, em qualquer segmento industrial.

\subsection{Considerações sobre o projeto}

Primeiro, é importante ser abordado o nome que se convencionou atribuir a estes profissionais de desenho técnico: projetistas. Ainda que o trabalho destes profissionais seja totalmente voltado ao produto (módulo) e a grande parte deles tenha formação em áreas relacionadas ao projeto (tais como arquitetura, edificações, design de interiores, entre outras) o design de produto nas indústrias de móveis é criado por outros profissionais, na etapa de desenvolvimento do produto.

Outra característica interessante é que durante a coleta dos dados realizada com os projetistas, os relatos não apresentaram padrões divergentes, ao contrário, as categorias recorrentes puderam ser identificadas já nas primeiras entrevistas, mesmo tomando o cuidado de selecionar profissionais de diferentes empresas de cozinhas e os entrevistando individualmente. Por meio das respostas às entrevistas, percebe-se que migram de empresas em uma média de três anos, o que contribui para a rotatividade no setor e talvez isto seja uma hipótese para o resultado de dados padronizados.

Destaca-se também que na coleta de dados realizada com os projetistas, foi identificado que alguns deles nunca acompanharam uma montagem de móveis para cozinha, pois alegam falta de tempo e não obrigatoriedade por parte da empresa. Desta maneira, os projetistas não sabem definir quais são as reais necessidades dos montadores durante a instalação dos móveis, não conhecem as ferramentas de trabalho destes profissionais e as limitações técnicas dos produtos. Do ponto de vista dos montadores também não participam do desenvolvimento do projeto executivo, de modo que tem acesso a ele somente quando a montagem já está agendada com o cliente. Mesmo em projetos mais elaborados, com instalações que necessitem de maior atenção e detalhamento, os montadores são raramente 
consultados, ou seja, as partes não se conversam, o que contribui para boa parte dos problemas apresentados no Capítulo 4.

Também é importante abordar aqui os novos arranjos nos projetos de cozinha, que os projetistas ora o definem como "projetos complexos", ora como "excesso de personalização". No entanto, invariavelmente referem-se aos mesmos itens: os clientes e os profissionais de arquitetura e design de interiores estão cada vez mais atentos e exigentes quanto a tudo que um projeto pode oferecer. Sendo assim, talvez seja cada vez mais comum ver módulos ganharem novos usos, prateleiras e painéis de MDF que em projeto se tornam estantes decorativas e o uso de eletrodomésticos cada vez mais tecnológicos nos projetos. A soma destes e outros itens certamente vão exigir dos projetistas muito mais dedicação e conhecimento técnico do produto e das ferragens, mas não há formação técnica específica para este fim.

Da mesma forma, é necessário ressaltar que boa parte dos problemas apresentados pelos montadores advém justamente da falta deste conhecimento técnico mais aprofundado, que muitas vezes não considera o montador como principal usuário deste projeto. Do lado dos projetistas, o acúmulo de funções e as urgências impostas pelos vendedores acabam sendo também um fator limitante no próprio desenvolvimento do projetista e na qualidade do seu trabalho. Assim, a combinação destes fatores tem impacto direto na montagem dos produtos e consequentemente nas principais ocorrências quanto aos materiais que são descartados.

\subsection{Considerações sobre a montagem}

De maneira geral, pode-se afirmar que tudo o que não foi bem planejado no processo resulta em problema para o montador, seja no projeto do produto, seja no projeto executivo ou na produção industrial. Esta, afinal de contas, é a última etapa do processo, de forma que é natural que determinados erros surjam somente nesta etapa. Na maior parte das vezes, os montadores têm autonomia para resolver os problemas, e são bem sucedidos em muitos casos, pois a maioria deles é marceneiro, tem o domínio técnico dos materiais e ferramentas, além do conhecimento tácito gerado pela experiência naquele ofício. Assim, se conclui que mesmo em produtos industriais, produzidos em grandes volumes e larga escala, a solução para determinados problemas pode surgir de processos ora manuais, ora informais e estes conhecimentos gerados no momento da instalação não são passados para o setor de projetos devido à ausência de integração entre os envolvidos neste processo. 
Outra característica que chamou a atenção foi a quantidade de peças que são descobertas batidas ou amassadas no momento de desembalar os produtos. A isto, pode-se dizer que 0 problema não é a falta de qualidade da embalagem do produto, mas provavelmente gerado no seu manuseio, o que ocorre principalmente com as peças grandes.

Conforme detalhado no Capítulo 4, algumas indústrias optam por pré montar os módulos em fábrica e enviá-los para os locais de montagens; em outras, todas as partes dos módulos são enviadas soltas. No caso de módulos que são enviados prontos, toma-se como exemplo um módulo tipo coluna, com $800 \mathrm{~mm}$ de largura, $2100 \mathrm{~mm}$ de altura e $600 \mathrm{~mm}$ de profundidade. Por mais que as transportadoras tenham cuidado, este é um armário grande e pesado, o que aumenta a incidência de danos ao produto ou em parte dele. Em todo caso, este assunto precisa ser mais bem explorado, para não apontar conclusões levianas quanto a processos que não foram investigados neste trabalho. Mesmo assim, pode-se afirmar que ainda que os módulos montados e transportados sofram mais acidentes que necessitem reparos ou trocas, o tempo de montagem e instalação no local é menor do que aquele realizado por peças e componentes separados. Este fator faz com que algumas indústrias optem por este procedimento.

Do lado da arquitetura, de maneira geral, percebe-se a falta de zelo na construção dos espaços, em particular no das cozinhas, com muitas paredes sem precisão, tortas e fora de esquadro, o que interfere na qualidade do resultado do trabalho das empresas de móveis, principalmente quando se considera o encontro das paredes sem ortogonalidade, pois as superfícies dos móveis são retas.

No caso das vistorias, que antecedem a montagem e que avaliam as condições dos espaços da cozinha, falta atenção de quem realiza, principalmente quanto à previsão de elementos que virão após a montagem dos móveis, como equipamentos de ar condicionado, forro de gesso, iluminação e que também devem ser projetados baseados no projeto da cozinha.

E de acordo com os dados levantados nesta pesquisa, talvez estas vistorias devam ser realizadas com o acompanhamento dos montadores, pois seria uma maneira de incorporálos ao processo e de identificarem eventuais discordâncias nos espaços da cozinha antes de iniciar a montagem. 


\subsection{Sugestões para novas pesquisas}

No que se refere ao tratamento dos resíduos sólidos, vale retomar aqui a necessidade de acompanhar o percurso das caçambas de coleta dos resíduos sólidos industriais até os receptores, para que possa ser feita uma análise mais esclarecedora, tanto do processo de triagem, quanto do processamento da biomassa para geração de energia.

No contexto industrial há a necessidade de abordar a dissonância entre as características dos insumos para os móveis (tais como o tamanho dos painéis de madeira e o tamanho dos laminados para revesti-los, por exemplo), que gera incompatibilidade na confluência dos produtos na indústria e, até em certa medida, é também um dos fatores responsáveis por parte do material descartado na etapa de produção industrial. Uma pesquisa mais aprofundada neste tema e que buscasse interligações entre os tipos de máquinas, processos e materiais, certamente poderia gerar um material muito esclarecedor para futuros designers, engenheiros, profissionais da indústria e interessados em geral.

Da mesma forma, a partir dos resultados obtidos nas entrevistas com os projetistas recomenda-se aqui uma investigação que considere a confluência entre os eletrodomésticos embutidos e o mobiliário modular para a cozinha, visto que, muitas vezes se mostraram incompatíveis.

Durante a observação em campo com os montadores, à parte os resultados obtidos relacionados ao tema desta investigação, outras abordagens poderiam ser exploradas, principalmente sob o olhar da ergonomia, que considere as condições do espaço de trabalho dos montadores nestes locais. Como principais fatores a serem apontados, destaca-se aqui o acesso a estes locais, a relação de transitoriedade, a estrutura física destes espaços e o fato de que muitas vezes tais locais de montagem ainda estão em obra e por esta razão possam não oferecer as condições de trabalho mais adequadas a estes profissionais.

O discurso da evolução do espaço doméstico da cozinha não é novo, entretanto, não está totalmente esgotado. Uma pesquisa possível pode explorar a relação entre os projetos que estão cada vez mais elaborados, com materiais e sistemas bem sofisticados, mas que muitas vezes não são compatíveis com os usuários destes espaços. Isto pode ser claramente notado durante esta investigação, na coleta de dados com os profissionais de assistência técnica, que apontaram como recorrentes os chamados de clientes solicitando esclarecimentos sobre o uso de determinada ferragem ou mecanismo que foi danificado por uso inadequado. 
Referências 
ABRAMOVAY, R., SPERANZA, J., PETITGAND, C. Lixo Zero: gestão de resíduos sólidos para uma sociedade mais próspera. São Paulo: Planeta sustentável: Instituto Ethos, 2013.

AKZO NOVEL. Disponível em < https://www.akzonobel.com/>. Acesso em: 19 abr.2017.

BARBOSA, A. L. A importância do estudo das funções e atividades no projeto e dimensionamento da habitação. 2007. 193 f. Dissertação (Mestrado em Arquitetura e Urbanismo) - Faculdade de Arquitetura e Urbanismo, Universidade de São Paulo, São Paulo, 2007.

BERNECK. Disponível em <http://www.berneck.com.br>. Acesso em: 08 fev. 2016.

BONSIEPE, G. Design: como prática de projeto. São Paulo: Blucher, 2012.

BONTEMPO. Disponível em <http://www.bontempo.com.br>. Acesso em: 02 nov.

BLUM. Disponível em <http://www.blum.com/br/pt/ Acesso em 07 jan. 2017.

BRASIL. Ministério do Meio Ambiente. Lei 12.305, de 2 de agosto de 2010. Política Nacional de Resíduos Sólidos. <Disponível em: http://www.mma.gov.br/port/conama /legiabre.cfm?codlegi=636>. Acesso em: 8 fev. 2016.

BRASIL. Decreto no 8.843, de 26 de julho de 1911. Crêa a reserva florestal no estado do Acre. Diário Oficial da União, Rio de Janeiro, RJ, 20 ago. 1911, Seção 1, p.10.415.

CARDOSO, R. Uma introdução à história do design. São Paulo: Edgar Blucher, 2000.

CORTE CERTO. Disponível em: <http:// www.cortecerto.com.br>. Acesso em: 17 nov. 2016.

CRESWELL, J. W. Projeto de pesquisa: métodos qualitativo, quantitativo e misto.

Tradução Luciana de Oliveira da Rocha. 2ed. Porto Alegre: Artmed, 2007.

Investigação qualitativa e projeto de pesquisa: escolhendo entre cinco abordagens. Tradução Sandra Mallmann. 3ed. Porto Alegre: Penso, 2014.

DELLANNO. Catálogo de produtos. Unicasa móveis: Bento Gonçalves, 2016. 14p.

DIAS, C. Independência energética. Entrevista concedida a Thiago Rodrigo. Revista Mobile. Curitiba, ano XXVIII, n. 269 p. 16-18, 2015.

DURATEX. Disponível em <http://www.duratexmadeira.com.br>. Acesso em: 08 fev. 2016.

ELLEN MACARTHUR FOUNDATION. Disponível em < http://www.ellenmacarthurfoundation. org/pt>. Acesso em: 08 jan.2017.

ESTADÃO. Casas Bahia e Ponto Frio entram no mercado de móveis planejados. Estadão, 7 nov. 2014. Disponível em: http://economia.estadao.com.br/noticias/negocios ,casas-bahia-e-ponto-frio-entram-no-mercado-de-moveis-planejados,1589550. Acesso em: 28 dez.2015.

FIBRAPLAC. Disponível em < http://www.fibraplac.com.br/> Acesso em: 08 fev. 2016. 
FLICK, U. Uma introdução à pesquisa qualitativa. Tradução Sandra Netz. Porto Alegre: Bookman, 2004.

FLORENSE. Disponível em <http://www.florense.com.br>. Acesso em: 25 out. 2016.

FORMAPLAS. Disponível em <http://www.formaplas.com.br>. Acesso em: 25 out. 2016.

FORMICA. Disponível em: <http://www.formica.com.br/> Acesso em: 08 fev. 2016.

FRANCO, A. A evolução do móvel residencial seriado em madeira reconstituída.

2010. 212 f. Dissertação (Mestrado em Arquitetura e Urbanismo) - Faculdade de Arquitetura e Urbanismo, Universidade de São Paulo, São Paulo, 2010.

. Conteúdo e Continente: integração entre o móvel componível e a habitação padronizada no Brasil. 2015. 265 f. Tese (Doutorado em Arquitetura e Urbanismo) Faculdade de Arquitetura e Urbanismo, Universidade de São Paulo, São Paulo, 2015

FUAD-LUKE, A. The eco-design handbook : a complete sourcebook for the home and office. London: Thames and Hudson, 2009.

GIBBS, G. Análise de dados qualitativos. Porto Alegre: Artmed, 2009.

GIL, A. C. Como elaborar projetos de pesquisa. São Paulo: Atlas, 2002.

HAFELE. Disponível em <https://www.hafele.com.br/pt/ Acesso em 07 jan. 2017.

HESKETT, J. Desenho industrial. Rio de Janeiro: José Olympio, 2006.

HOMEM, M. C. Cozinha e indústria em São Paulo: do rural ao urbano. São Paulo: Edusp, 2015.

INSTITUTO DE PESQUISA E INTELIGÊNCIA DE MERCADO. Disponível em <http://www.iemi.com.br>. Acesso em: 27 out. 2016.

INDÚSTRIA BRASILEIRA DE ARVORES. Cartilha. Disponível em: <http://iba.org/images shared/iba_2015.pdf.> Acesso em: 28 dez. 2015.

KAZAZIAN, T. (org.) Haverá a idade das coisas leves: design e desenvolvimento sustentável. São Paulo: Senac, 2005.

KITCHENS. Disponível em <http://www.kitchens.com.br> Acesso em 07 jan. 2017.

LEICHT. Price and Type List. Leicht Küchen AG: Waldstetten, 2016. 798p. Disponível em <http://www.leicht.com.br >. Acesso em: 30 set.2016.

LEITE, M. A floresta amazônica. São Paulo: Publifolha, 2001.

LEMOS, C. Cozinhas, etc.: um estudo sobre as zonas de serviço da casa paulistana. São Paulo: Perspectiva, 1978. 
LEONARD, A. A História das coisas: da natureza ao lixo, o que acontece com tudo o que consumimos. Rio de Janeiro: Zahar, 2011.

LIMA, M. A. M. Introdução aos materiais e processos para designers. Rio de Janeiro: Ciência Moderna, 2006.

LÖBACH, B. Desenho industrial: Bases para a configuração dos produtos industriais. São Paulo: Edgar Blucher, 2001.

MADEPAR. Disponível em <http://www.madepar.com.br>. Acesso em: 08 fev. 2016.

MANZINI, E.; VEZZOLI, C. O desenvolvimento de produtos sustentáveis. São Paulo: Edusp, 2011.

MASISA. Disponível em <http://www.masisa.com.br>. Acesso em: 08 fev. 2016.

McDONOUGH, W.; BRAUNGART, M. Cradle to Cradle: remaking the way we make things. New York: North Point Press, 2002.

The Upcycle. New York: North Point Press, 2013.

MINDLIN, H. Organização racional da cozinha. In Revista Acrópole, São Paulo, v. 1, n. 2 p. 19-22, 1938. Disponível em http://www.acropole.fau.usp.br/edicao/2. Acesso em: 04 jan.2017.

MORAES, D. Limites do Design. São Paulo: Studio Nobel, 1999.

NASCIMENTO, L.C.P. Coletânea dos roteiros de tópicos propostos para a disciplina Introdução à Metodologia de Pesquisa em Design. Universidade de São Paulo:

Faculdade de Arquitetura e Urbanismo, mar.2015. 82 p.

NAVARRO, R.F. A Evolução dos Materiais. Parte1: da Pré-história ao Início da Era Moderna. Revista Eletrônica de Materiais e Processos, Vol. 1, No 1. Universidade Federal de Campina Grande, 2006.

ORNARE. Disponível em <http://www.ornare.com.br> Acesso em 28 dez. 2015.

PANERO, J. ,ZELNIK, M. Dimensionamento humano para espaços interiores: um livro de consulta e referência para projetos. Barcelona, Gili: 2011.

PAPANEK, V. Arquitectura e Design: ecologia e ética. Lisboa: Edições 70, 1995.

PLATCHECK, E. Design Industrial: metodologia de eco design para o desenvolvimento de produtos sustentáveis. São Paulo: Atlas, 2012.

POGGENPOHL. Disponível em <http://www.poggenpohl.com/pt/> Acesso em: 25 out. 2016.

SCA. Disponível em <http://www.sca.com.br>. Acesso em: 25 out. 2016.

SECURIT. Disponível em: <http://www.securit.com.br> Acesso em: 07 jan. 2017. 
. Cozinhas planificadas. In Revista Acrópole, São Paulo, v. 1, n. 198, p. 286-287, 1955. http://www.acropole.fau.usp.br/edicao/198/67. Acesso em: 07 jan.2017.

SISTEMA NACIONAL DE INFORMAÇÕES FLORESTAIS. Disponível em <http://www.florestal.gov.br/>. Acesso em: 28 dez. 2015.

SILVA, J.L.M. Cozinha modelo: o impacto do gás e da eletricidade na casa paulistana (1870-1930). São Paulo, Edusp: 2008.

SANTOS, M. C. L. Móvel Moderno no Brasil. São Paulo: Olhares, 2015. (coord.). Design, Resíduo e Dignidade. São Paulo: Olhares, 2014.

TODESCHINI. Disponível em <http://www.todeschinisa.com.br>. Acesso em: 25 out. 2016.

TRINDADE, M. Publicação eletrônica [mensagem pessoal]. Mensagem recebida por <andremidoes@usp.br> em 24 ago. 2016.

UNICASA MÓVEIS. Disponível em <http://www.unicasamoveis.com.br>. Acesso em: 02 nov. 2015.

VALCUCINE. Disponível em <http://www.valcucine.com/> Acesso em: 25 out. 2016.

VERISSIMO, F.S., BITTAR, W.S.M. 500 anos da casa no Brasil. Rio de Janeiro, Ediouro: 1999.

YIN, R. Estudo de caso: planejamento e métodos. Porto Alegre: Bookmam, 2001.

WEY, E. A casa de todos os tempos: Cozinha. São Paulo: Ofício das Palavras, 2007.

\section{Entrevistas}

AMADO, Ana Claudia. Entrevista. São Paulo, 28 set.2016.

AN, Kennya. São Paulo, 20 out.2016.

BARALTI, Marcel. Entrevista. São Paulo, 26 out.2016.

BASSO, Daniel. Entrevista. São Paulo, 08 set.2016.

BELLIZIA, Eduardo. Entrevista. São Paulo, 16 jul. 2015.

BRITO, Laercio. Entrevista. São Caetano do Sul, 09 nov.2016.

BSCHOR, Gunter. Entrevista. São Paulo, 09 nov.2016.

CAMPIOL, Patricia. Entrevista. São Paulo, 04 mai. 2016.

CASTRO, Agnaldo de. Entrevista. Cotia, 21 jan.2017.

DALLAGO, Ane. Entrevista. Bento Gonçalves, 09 nov.2015. 
FERREIRA, Felipe. Entrevista. Osasco, 25 ago.2015.

MAGNELLI, Maria Christina. Entrevista. Guarulhos, 29 jul.2015.

MAMMANA, Sabrina. Entrevista. São Paulo, 13 set.2016.

MATSUMOTO, Sayuri. Entrevista. São Paulo, 27 set.2016.

NAKANO, Fabio. Entrevista. Bento Gonçalves, 09 nov.2015.

NOGUEIRA, Rosangela. Entrevista. São Paulo, 30 set.2016.

NUNES, Juliane. Entrevista. São Paulo, 24 out.2016.

NUNES, Sabrina. Entrevista. Osasco, 28 out.2016.

PISAREVSKI, Renata. Entrevista. São Paulo, 30 set.2016.

PLATO, Armando de. Entrevista. Guarulhos, 20 abr. 2015.

RAMOS, Leandro. Entrevista. São Paulo, 25 mai.2016.

SANTOS, Antonio dos. Entrevista. São Paulo, 28 dez.2016.

SANTOS, Joerly. Entrevista. São Paulo, 08 ago.2016.

SCHATTAN, Esther. Entrevista. São Paulo, 07 jul. 2015.

SELLGE, Ingrid. Entrevista. São Paulo, 30 out.2016.

SILVA, Adriane Martins. Entrevista. São Paulo, 24 de out.2016.

SILVA, Jose Eudocio. Entrevista. Osasco, 02 set. 2016.

SOUZA, Marcelo. Entrevista. São Paulo, 17 set.2016. 
Apêndice 
Profissionais entrevistados - PRODUÇÃO INDUSTRIAL

Diretores industriais:

BARALTI, Marcel.

SCHATTAN, Esther.

FERREIRA, Felipe.

MAGNELLI, Maria Christina.

Designers de produto:

BELLIZIA, Eduardo.

DALLAGO, Ane.

Setores de produção:

BRITO, Laercio.

CASTRO, Agnaldo de.

NAKANO, Fabio.

PLATO, Armando de.

SANTOS, Joerly.

Observação não participante nas indústrias de móveis - PRODUÇÃO INDUSTRIAL

$\begin{array}{lr}\text { Móveis Bartira, São Caetano do Sul/SP } & -09 / 11 / 2016 \\ \text { Novaes Ferreira, Osasco/SP } & -12 / 06 / 2015 \\ \text { Ornare, Cotia/SP } & -14 / 07 / 2015 \\ \text { Securit, Guarulhos/SP } & -20 / 04 / 2015 \\ \text { Unicasa, Bento Gonçalves/RS } & -09 / 11 / 2015\end{array}$


Profissionais entrevistados - PROJETO

Projetistas e coordenadores:

AMADO, Ana Claudia.

AN, Kennya.

BASSO, Daniel.

MAMMANA, Sabrina.

MATSUMOTO, Sayuri.

NOGUEIRA, Rosangela.

NUNES, Juliane.

NUNES, Sabrina.

PISAREVSKI, Renata.

RAMOS, Leandro.

SELLGE, Ingrid.

SILVA, Adriane Martins.

Assistência Técnica:

CAMPIOL, Patricia.

SOUZA, Marcelo.

Profissionais entrevistados e montadores participantes - MONTAGEM

ALMEIDA, Anderson.

ANDRADE, Silvano.

BSCHOR, Gunter.

COSTA, Leonardo.

LIMA, Ivan.

MEDEIROS, Cledson.

SANTOS, Antonio dos.

SILVA, Jose Eudocio. 
Roteiro para Entrevista semi estruturada - PRODUÇÃO INDUSTRIAL

- Materiais

1. Entre o MDF e o MDP, qual destes é o mais utilizado e por quê?

2. Na fabricação dos móveis modulares onde é usado o MDF e onde é usado o MDP?

3. Quais são os revestimentos para estes painéis em MDF e MDP?

4. Quais são os critérios para as escolha destes revestimentos?

5. Os fabricantes dos painéis de MDF e MDP comercializam vários tamanhos para estes painéis. Como é feito a escolha das medidas para compra destes painéis por parte da indústria?

6. Além do MDF e do MDP qual outro material é utilizado como matéria prima?

- Descarte de material excedente

1. Como é gerado o excedente de produção?

2. Qual o volume deste descarte?

3. O descarte é mais recorrente em qual material?

4. De que maneira este material descartado é tratado dentro da fábrica?

5. Se armazenado em caçambas, qual o tempo médio que as caçambas ficam nas fábricas?

6. Como é o acompanhamento efetivo do destino deste descarte junto às empresas de coleta?

- Iniciativas de aproveitamento do descarte

1. Que iniciativas de aproveitamento deste descarte esta empresa já fez?

2. Em um balanço geral, como foi o desempenho destas iniciativas?

3. Quais os desafios para o aproveitamento deste descarte a indústria apontaria?

4. De que forma este descarte poderia ser aproveitado dentro da indústria? 
Identificação:

Idade:

Tempo de atividade como projetista de móveis, em anos:

Projetista de armários e cozinhas:

1. Formação

2. Como iniciou como projetista?

3. Participou de treinamento formal? O que foi abordado neste treinamento?

4. Você desenvolve os projetos finais, de execução. Como é o percurso para este projeto chegar até você?

5. Na compatibilização do projeto vendido x execução, quais tipos de alterações você tem a autonomia de propor?

Realiza plano de corte dos produtos?

Compatibiliza considerando aspectos técnicos ou estéticos?

6. Durante o desenvolvimento do projeto final, quais aspectos ou detalhes você dedica mais atenção?

7. Quais os aspectos limitadores do seu trabalho, o que atrapalha o desenvolvimento do projeto final?

8. Quando o projeto passa por alterações e/ou revisões, é você mesmo quem faz? Qual/Quais tipos de alteração são mais recorrentes?

9. Dentro da sua função de projeto, quais os seus contatos internos? Vendedores/Montadores/Coordenador de projeto/Medidores...

10. Com qual frequência você acompanha a montagem/instalação dos projetos que você desenvolveu?

11. Nestas observações em campo de armários e cozinhas montadas, o que mais você procura observar?

12. É comum que erros no projeto tenham impacto negativo na instalação dos móveis. Quais os seus erros mais recorrentes?

E quais as principais ações que você toma para minimizar estes erros?

13. Com qual frequência você incorpora em seus projetos finais peças que precisarão de ajustes na hora da montagem? Por quê?

Você solicita ajustes de largura? Profundidade? Altura de armários?

14. Para este ajuste em obra, qual o tipo de peças mais recorrentes? Existe diferença para o armário de dormitório e a cozinha?

15. Alguns produtos fora dos catálogos, chamados de "especiais" são utilizados em projetos. Em quais situações você sugere estas peças? 
16. Quais programas de desenho você utiliza e já utilizou em seus projetos? Quais pontos positivos e negativos, você atribuiria a cada um destes programas?

17. O que você mudaria nos programas de desenho utilizados para o projeto de armários de dormitório e cozinhas?

18. Dentro da sua função de projetista, qual atividade ainda depende de desenho manual ou ajustes manuais no papel? Por quê?

19. Como você mede a sua produtividade? Por módulos, metragem quadrada de projeto? E qual a sua produtividade por semana, por exemplo?

20. De quando você iniciou como projetista para hoje, o que mudou na profissão? E como você vê esta atividade nos próximos anos? 
Modelo de ficha de observação - MONTAGEM

Ficha de observação para acompanhamento de MONTAGEM

Data da Observação: $/ 201$

Nome do Instalador:

Endereço:

Tipo de Imóvel: Casa/Apartamento:

Dia da Semana:

Horário - entrada:

Horário - saída:

Quantidade de Módulos: 